\title{
San Antonio Mission Trails Statewide Transportation Enhancement Project Volume I
}

Diane A. Cargill

Barbara A. Meissner

Anne A. Fox

I. Waynne Cox

Follow this and additional works at: https://scholarworks.sfasu.edu/ita

Part of the American Material Culture Commons, Archaeological Anthropology Commons, Environmental Studies Commons, Other American Studies Commons, Other Arts and Humanities Commons, Other History of Art, Architecture, and Archaeology Commons, and the United States History Commons

Tell us how this article helped you.

This Article is brought to you for free and open access by the Center for Regional Heritage Research at SFA ScholarWorks. It has been accepted for inclusion in Index of Texas Archaeology: Open Access Gray Literature from the Lone Star State by an authorized editor of SFA ScholarWorks. For more information, please contact cdsscholarworks@sfasu.edu. 


\section{San Antonio Mission Trails Statewide Transportation Enhancement Project Volume I \\ Creative Commons License \\ (c) (i) (8)}

This work is licensed under a Creative Commons Attribution-NonCommercial 4.0 International License 


\section{Statewide Transportation Enhancement Project \\ San Antonio Mission Trails}

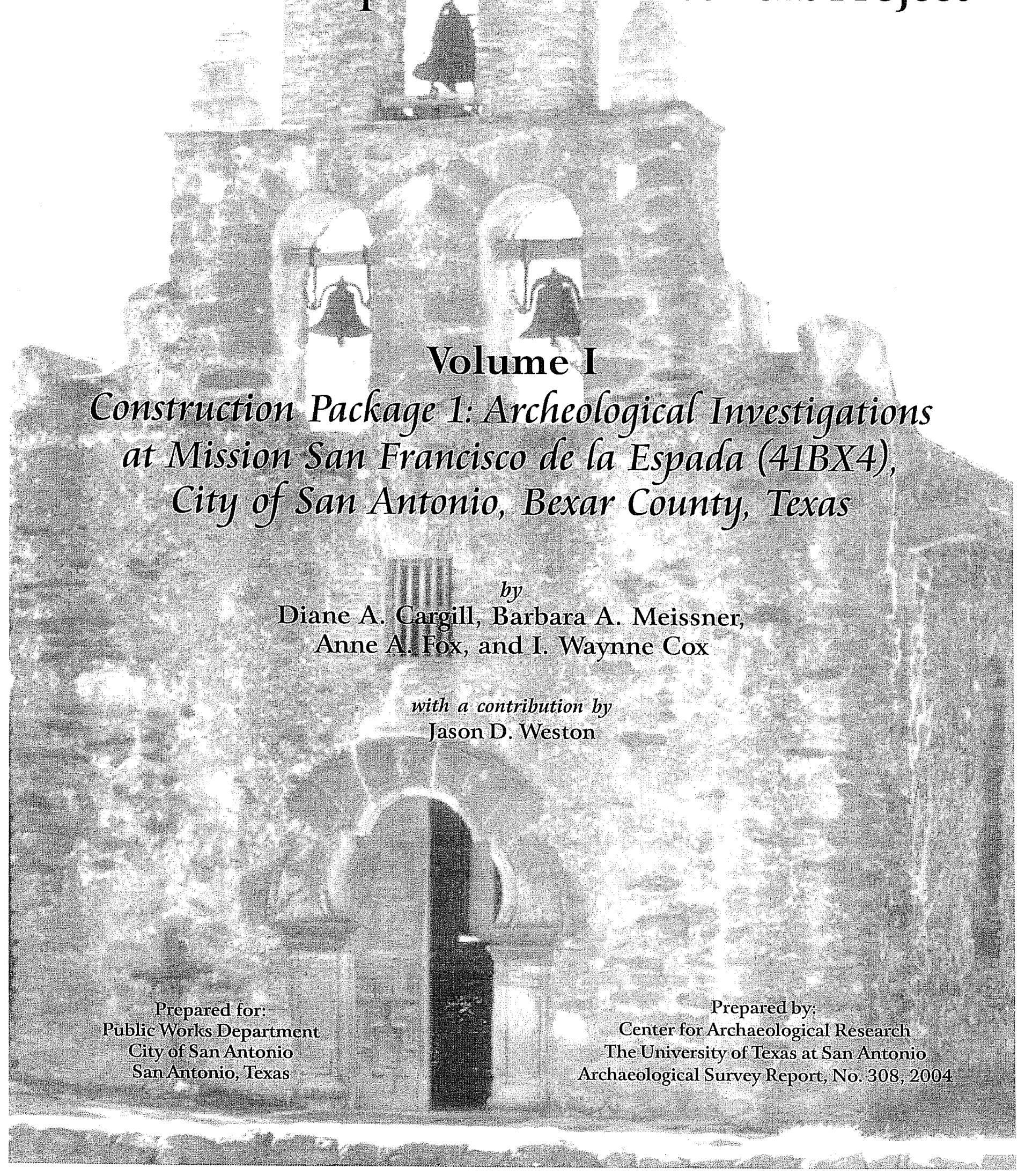




\title{
San Antonio Mission Trails Statewide Transportation Enhancement Project
}

\author{
Volume I \\ Construction Package 1: Archeological Investigations \\ at Mission San Francisco de la Espada (41BX4), \\ City of San Antonio, Bexar County, Texas \\ by \\ Diane A. Cargill, Barbara A. Meissner, \\ Anne A. Fox, and I. Waynne Cox \\ with a contribution by \\ Jason D. Weston
}

Texas Antiquities Committee Permit No. 2051

CSJ: 0915-12-163

Package 1 of San Antonio Mission Trails Statewide Transportation Enhancement Project

\section{Principal Investigator \\ Steve A. Tomka}

Former Principal Investigators

Robert J. Hard and C. Britt Bousman

Prepared for: Public Works Department

City of San Antonio

San Antonio, Texas

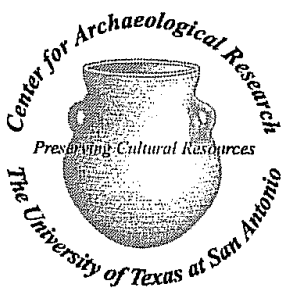

(C)2004
Prepared by:

Center for Archaeological Research The University of Texas at San Antonio Archaeological Survey Report, No. 308 
A list of publications offered by the Center for Archaeological Research is available. Call (210) 458-4378; write to the Center for Archaeological Research, The University of Texas at San Antonio, 6900 N. Loop 1604 W., San Antonio, Texas 78249-0658; e-mail to car@lonestar.utsa.edu; or visit CAR's web site at http://car.utsa.edu. 


\section{Abstract:}

This report represents the first volume detailing the results of archeological and archival investigations associated with the San Antonio Mission Trails Project. The project consists of a system of hike-and-bile trails under development by the City of San Antonio. Its purpose of the trails is to connect the Alamo with the four other Spanish Colonial missions in San Antonio. The project is divided into five packages or phases. Only the first four phases include archeological investigations. Because the project is estimated to last several years, rather than waiting for the completion of the entire project before issuing the report of findings, each volume issued in this series will report on the findings of a specific package or closely related packages. Archeological investigations performed for all phases of the Mission Trails Project were, or will be, conducted under Texas Antiquities Permit No. 2051.

In October of 1998, the Center for Archaeological Research (CAR) of the University of Texas at San Antonio contracted with the City of San Antonio, Bexar County, Texas, to provide archeological services to assess damage done by unmonitored construction activities to areas surrounding Mission San Francisco de la Espada, San Antonio, Texas. These investigations were part of the Mission Trails Project which was intended to provide archival research and monitoring of all construction activities in areas of the project that had the potential to impact cultural resources eligible for inclusion in the National Register of Historic Places or for designation as State Archeological Landmarks.

Between December 1998 and April 1999, CAR performed the archeological investigations at Mission Espada. A total of 49 units was excavated in three areas designated as the Northwest Gateway, the Hike-and-Bike Trail, and Drainage System A. In addition, excavation by construction crews in Drainage Systems A and B and replacement of pipes within the Espada Acequia was monitored. Two backhoe trenches were excavated in Drainage System A and seven in Drainage System B.

Sixteen test units excavated in the Northwest Gateway revealed the remnants of a limestone foundation wall; possibly a portion of the original west wall of the mission, built around 1756 . The units also revealed limestone paving outside the wall. Evidence seen during the excavation of the Northwest Gateway units shows that the area has been disturbed many times, probably beginning in Colonial times and continuing to the present. Damage to what remains of the foundations is due, among other things, to the multiple attempts to insert posts in this area and possibly to road grading as well. Installation of utilities through the area has also had an impact. Even though the area has been badly damaged by various activities through time, a large number of Colonial artifacts are still present, and evidence of the unreconstructed southern gate room is still present.

Twenty-six units were excavated in the Hike-and-Bike Trail area. This area presents a picture of varied disturbance; some units appeared to be in areas of essentially intact deposits and had no twentieth-century artifacts below the first $10-\mathrm{cm}$ level, while others were in extensively disturbed areas. A portion of the Hike-and-Bike Trail was bladed prior to CAR's monitoring of the construction activities. The historic deposits along the Hike-and-Bike Trail are not deeply buried, and although in some areas there may have been little or no damage done to these deposits by the blading of the trail, in other areas significant damage was done. Test units revealed that at least some areas of the trail have essentially intact Colonial deposits, and these deposits tend to be near the ground surface.

Seven test units and two backhoe trenches were excavated in Drainage System A. A Colonial-period pottery kiln and a pit feature were encountered. The pit feature was located near the kiln and may have been a borrow pit for clay. No significant cultural deposits were identified during the monitoring of the replacement of pipes in the Espada Acequia and the excavation of the seven backhoe trenches in Drainage System B. 


\section{Table of Contents:}

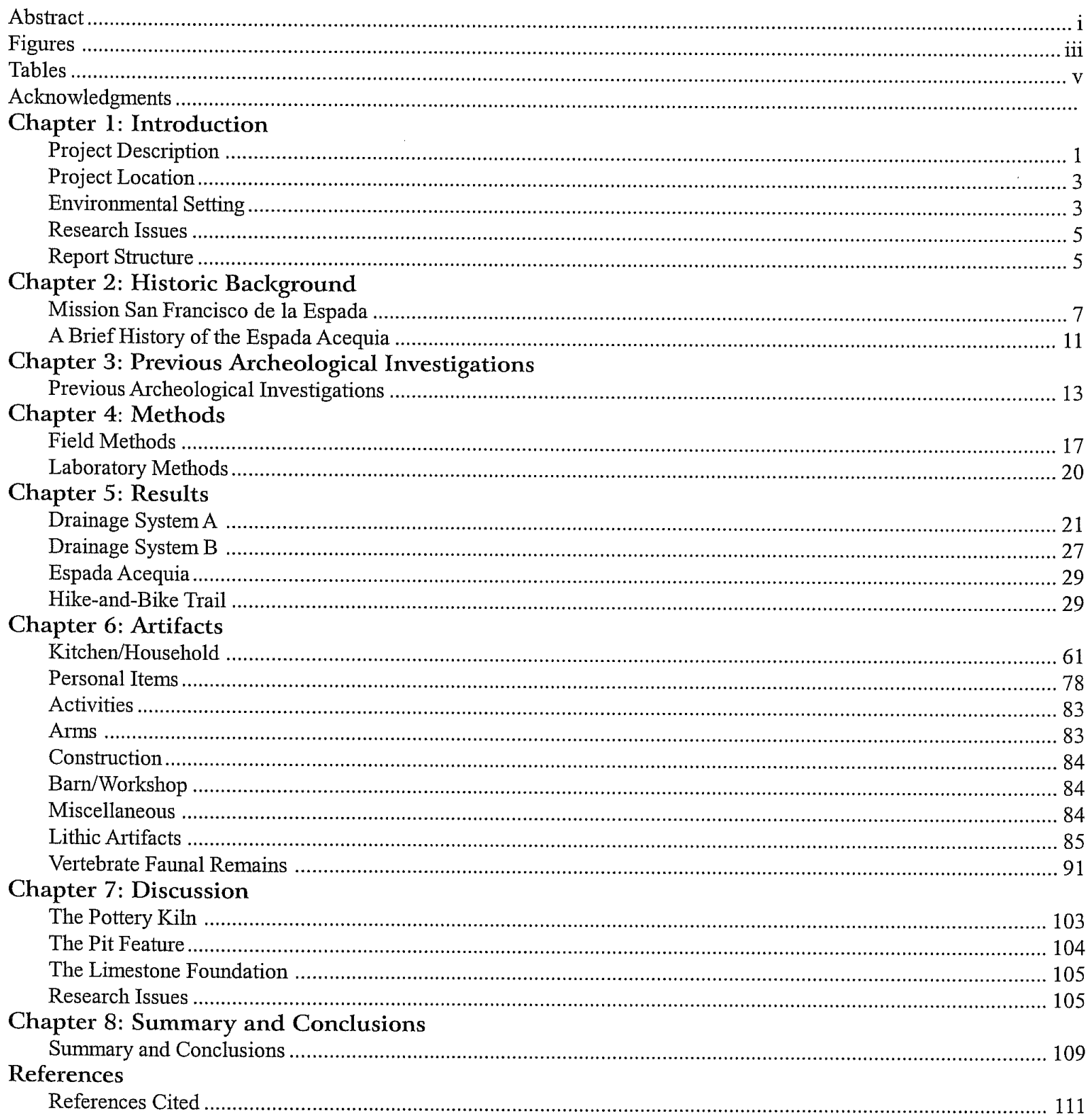




\section{Figures:}

Figure 1-1. Map of south San Antonio showing project location. 2

Figure 1-2. Map of region around Mission Espada, showing the old and current course of the San Antonio River, roads, acequias, and location of Drainage Systems A and B.

Figure 2-1. Plan map of Mission Espada.

Figure 2-2. Map of the west wall of Mission Espada, north of the Northwest Gateway, showing property ownership and jacal structures present, 1824-1827 (based on Mission Records). ........................................................................ 10

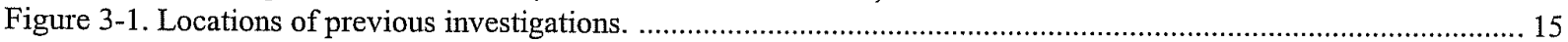

Figure 4-1. Placement of test units and backhoe trenches in Drainage System A. ......................................................... 18

Figure 4-2. Placement of test units in Northwest Gateway area and along Hike-and-Bike Trail...................................... 19

Figure 5-1. TUs 34 and 35, showing pit feature in Drainage System A. ………….................................................. 22

Figure 5-2. Profile of the south wall of BHT 1, showing pit feature.

Figure 5-3. Profile of north wall of kiln, showing remains of flue holes and plastered brick interior of kiln..................... 25

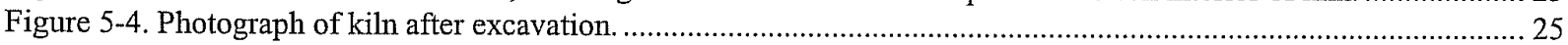

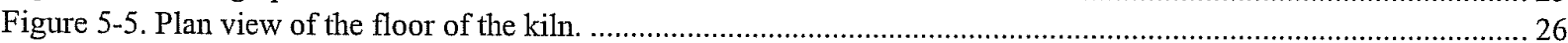

Figure 5-6. Faience plate fragment in the bottom of the kiln. .............................................................................. 26

Figure 5-7. Photo showing trench for Drainage System A storm sewer passing under reinforced concrete pipe carrying

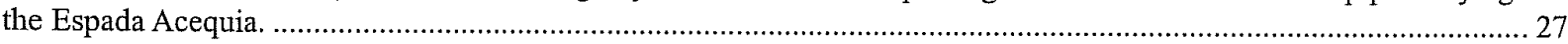

Figure 5-8. Map of Drainage System B, showing location of backhoe trenches. .............................................................. 28

Figure 5-9. Completed crossing of Espada Acequia at Espada Road near the southwest corner of the mission. .................2 29

Figure 5-10. Plan map of Northwest Gateway units, showing Colonial wall foundation and flagstone floor west of the

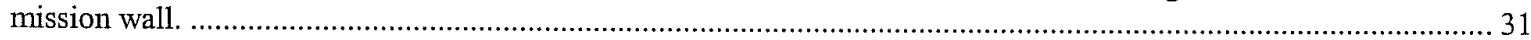

Figure 5-11. Colonial foundation in Northwest Gateway, TUs 48, 47, 44, and 45, looking south. ....................................... 32

Figure 5-12. The southern Northwest Gateway units, looking south.

Figure 5-13. Flagstone paving in west of Colonial wall foundation. ............................................................................. 33

Figure 5-14. Profile of the south wall of TU 28, showing limestone wall foundation. ................................................... 34

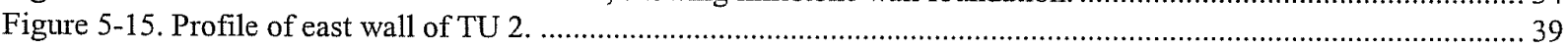

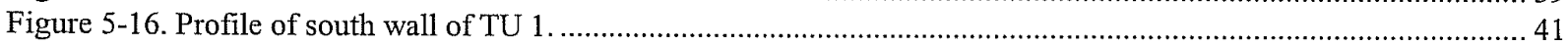

Figure 5-17. East wall of TU 1, showing Colonial wall foundation with reconstructed wall above.................................. 43

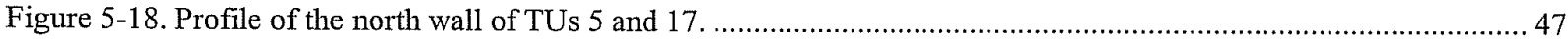

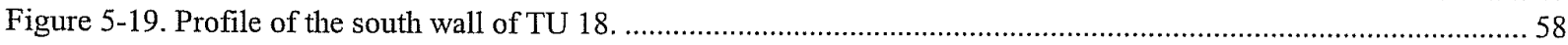

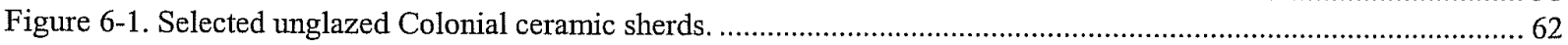

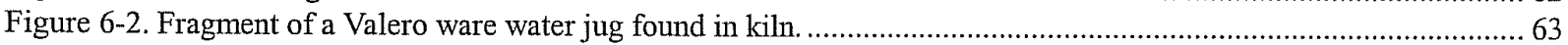

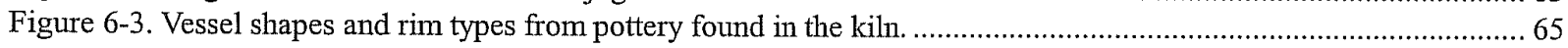

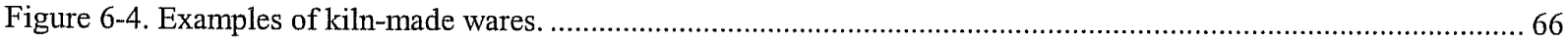

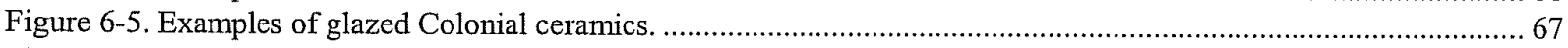

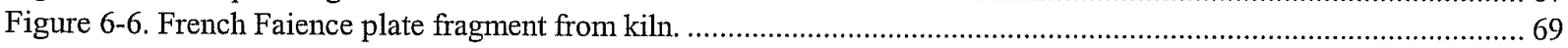

Figure 6-7. Examples of decorated white earthenwares. ……............................................................................... 70

Figure 6-8. Examples of other refined earthenwares.

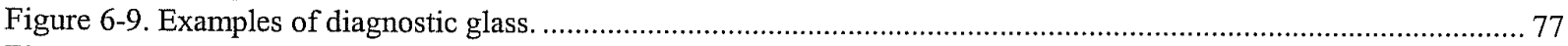

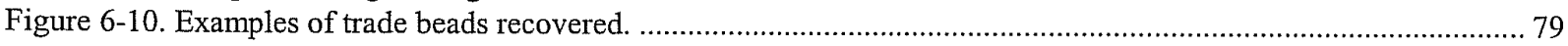

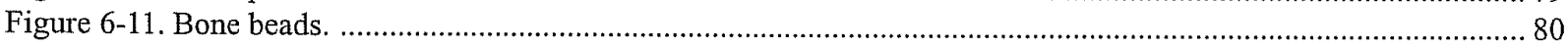

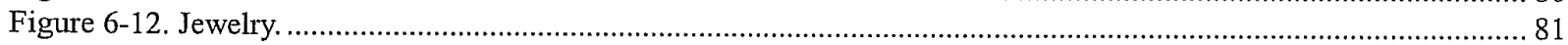

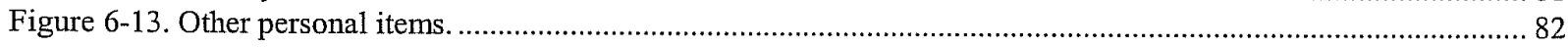

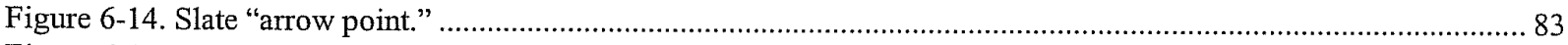

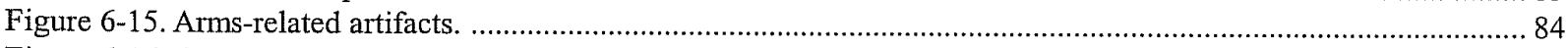

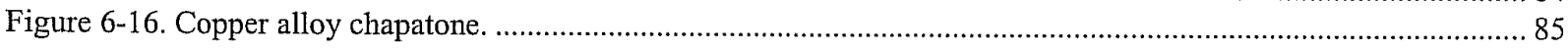




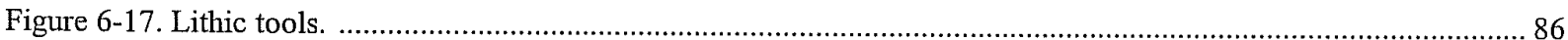

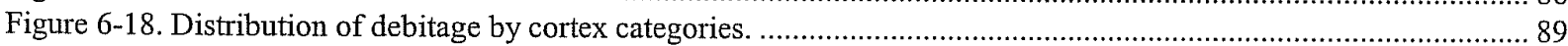

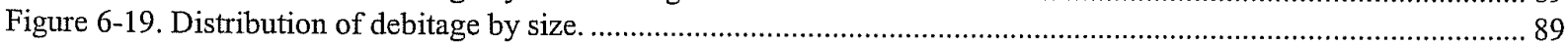

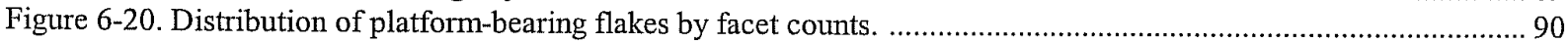

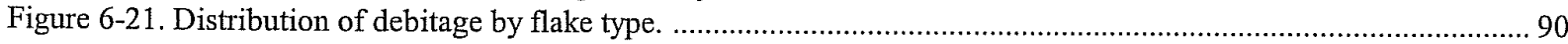

Figure 6-22. Soft-shelled turtle carapace, showing impact scars and burning around edge. ......................................... 98

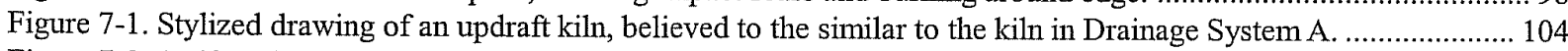

Figure 7-2. Artifact density (artifacts per $\mathrm{m}^{3}$ ) for units along the Hike-and-Bike Trail (south to north). ...................... 106 


\section{Tables:}

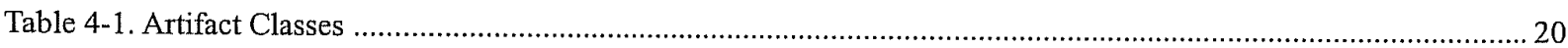

Table 5-1. Artifacts Recovered from the Pit Feature (TU 34 \& TU 35) in Drainage System A ..........................................22

Table 5-2. Artifacts Recovered from the Pottery Kiln (TUs 32, 33, 43, 46 \& 49) in Drainage System A ...........................24

Table 5-3. Artifacts from the Northwest Gateway Units (TUs 27-31, 36-42, 44-45, $47 \& 48$ ) ....................................30

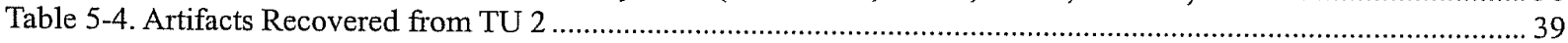

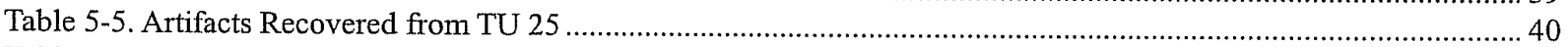

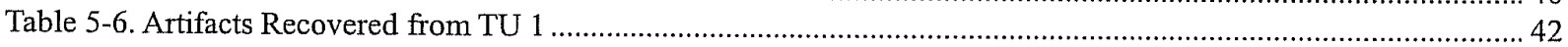

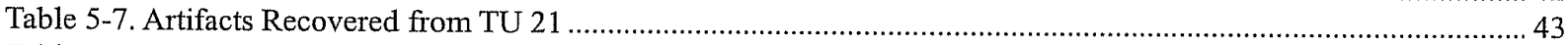

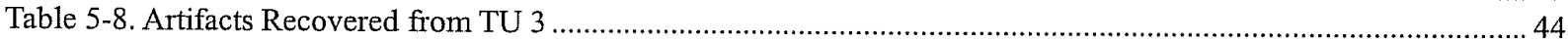

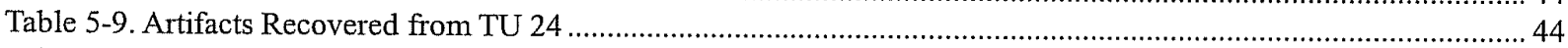

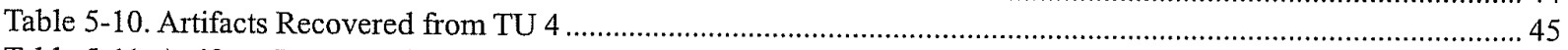

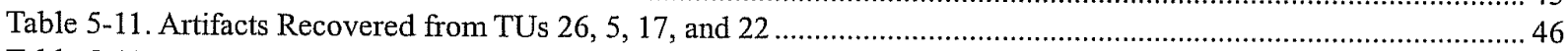

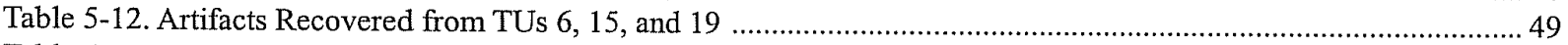

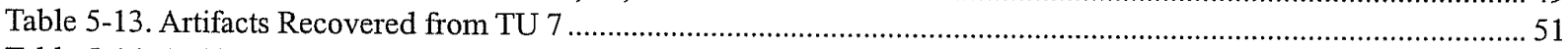

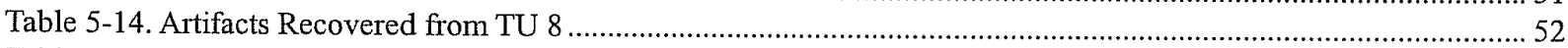

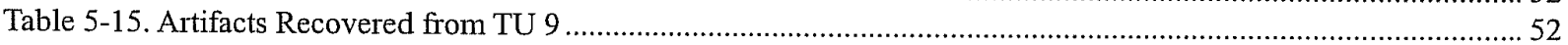

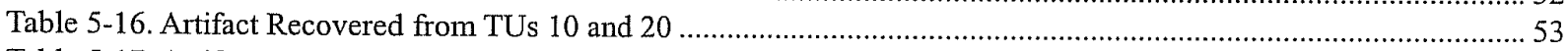

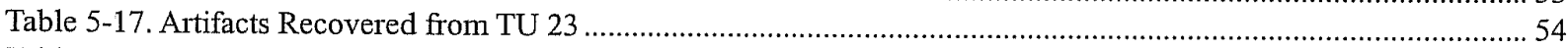

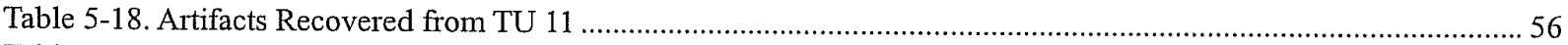

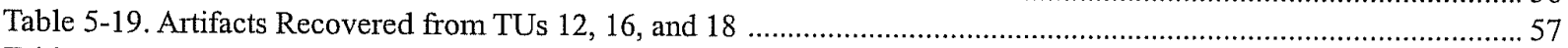

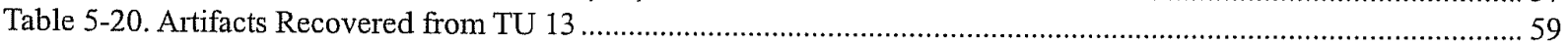

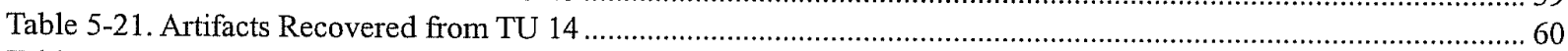

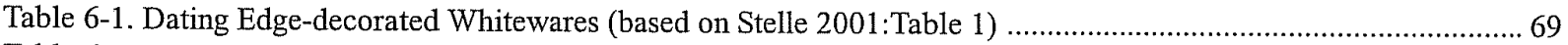

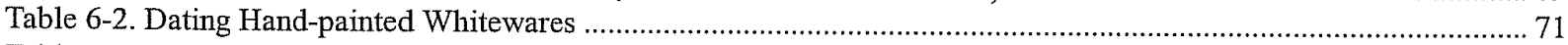

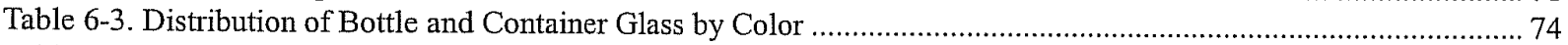

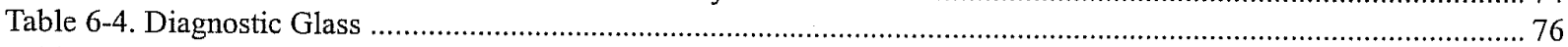

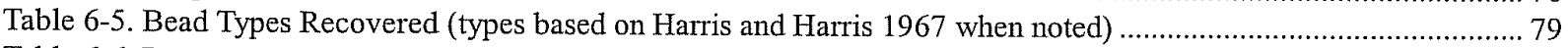

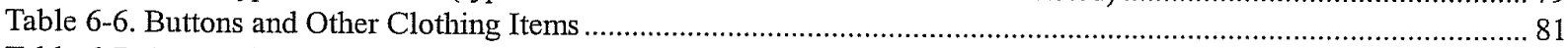

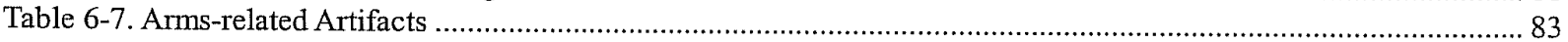

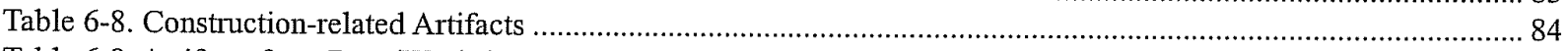

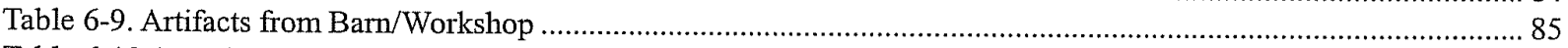

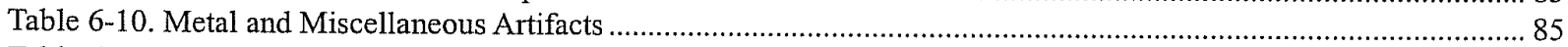

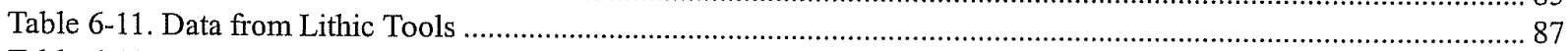

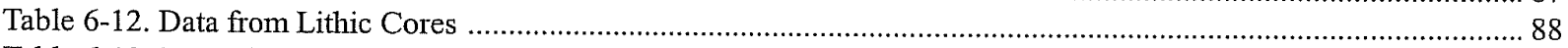

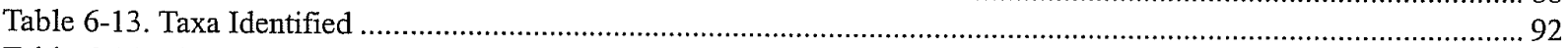

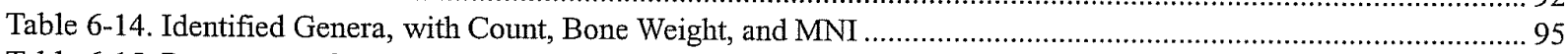

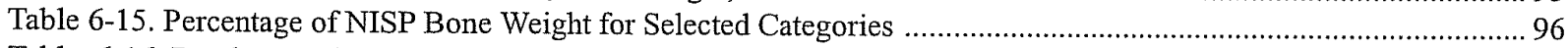

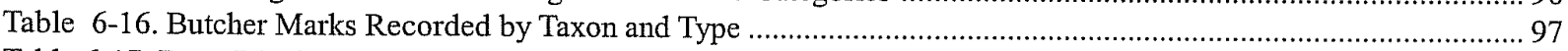

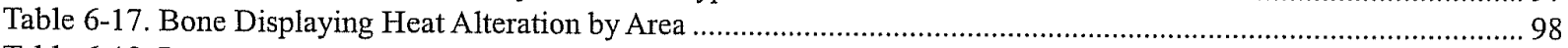

Table 6-18. Percent of NISP Bone Weight for Six Categories from Six Projects at Four San Antonio Missions .............. 99

Table 6-19. Comparison of Current Project with Bone from Priest Quarters Project (Meissner 2000a) ....................... 100

Table 6-20. Location of Identified Bovid Long Bone Fragments ....................................................................... 100

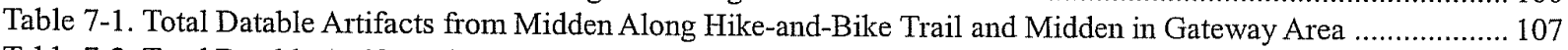

Table 7-2. Total Datable Artifacts from Units with Low Artifact Density on Hike-and-Bike Trail ............................... 107

Table 7-3. Total Datable Artifacts from Units with High Artifact Density on the Northern Hike-and-Bike Trail ........... 107

Table 8-1. Total Artifacts Dating from the Eighteenth through Early-Twentieth Centuries Compared to Such Artifacts

Recovered from Level 1 in the Non-bladed Units along the Hike-and-Bike Trail ............................................. 109 


\section{Acknowledgments:}

Given the long history of work on the Package 1 portion of the Mission Trails Project and the complexity of coordination between agencies, several individuals deserve acknowledgment for playing critical roles in helping to move the project forward over the years. Included among them is Robert J. Hard and C. Britt Bousman, both formerly of the Center for Archaeological Research; Gabriel Perez and Dean Bayer of the City of San Antonio of Public Works Department; and Ann McGlone and Clint McKenzie of the City of San Antonio Historic Preservation and Urban Design Office. Dr. James E. Bruseth and Mr. Mark H. Denton of the Texas Historical Commission and Mr. Al McGraw of the Texas Department of Transportation Environmental Affairs Division reviewed scopes of work and draft reports in a timely fashion and were critical in maintaining the flow of information and achieving the level of coordination necessary for such a complex project.

The successful completion of the field and laboratory efforts for Package 1 of the Mission Trails Project is due to the tireless hard work and collaboration of a large number of individuals from the Center for Archaeological Research. The late Waynne Cox spent many hours monitoring the excavations of City crews and kept a sharp eye open for remnants of San Antonio's history. Diane Cargill directed a large and able crew in the field including D. Edmondson, A. Figueroa, J. Francis, C. Horell, R. Jones, K. Kvernes, and K. Miller, and R. Robinson. These same individuals later participated in the laboratory efforts associated with the project and were directed by Marybeth S. F. Tomka, Laboratory Coordinator for the Center for Archaeological Research. J. Weston and B. Meissner carried out special studies for the report. Richard Young and Bruce Moses produced the graphics presented in the report and Johanna Hunziker formatted the final report. Drs. Robert J. Hard, C. Britt Bousman and Steve A. Tomka served as Principal Investigators at different times during the project. Our sincere thanks and gratitude go out to one and all for making this project and report possible. 


\section{Chapter 1: Introduction}

This report represents the first volume detailing the results of archeological and archival investigations associated with the San Antonio Mission Trails Statewide Transportation Enhancement Project. Portions of this project consist of systems of hike-and-bike trails under development by the City of San Antonio, Bexar County, Texas. The purpose of these trail systems is to connect the Alamo with the four other Spanish Colonial missions in San Antonio. Archeological monitoring and/or other archeological services were required during the project to reduce construction impacts to cultural resources that may be eligible for inclusion in the National Register of Historic Places or for designation as State Archeological Landmarks, and to record and mitigate any impacts to such resources that cannot be avoided. This requirement was necessary to ensure that all participating parties are in compliance with the Programmatic Agreement Regarding the Implementation of Transportation Enhancement Activities Under the Intermodal Surface Transportation Efficiency Act of 1991. This agreement was executed in 1994 between the Advisory Council on Historic Preservation, the Federal Highway Administration, the Texas State Historic Preservation Office and the Texas Department of Transportation (TxDOT). In September 1998, the City of San Antonio through its Department of Public Works contracted with the Center for Archaeological Research (CAR) of The University of Texas at San Antonio provide the archeological services required on this project.

The project is divided into five packages or phases. Work on Package 1 was begun in 1998 and completed in January 2000. The work consisted of the installation of hike-andbike lanes and multipurpose (drive, bike and hike lanes) roads connecting Mission Espada with Mission San Juan Capistrano. Work on Package 3 occurred next, and involved trail and street improvements in the vicinity of Mission Concepción. This work was completed in September 2004. Package 2 consists of street and drainage improvements on Mission Road between S.E. Military Highway, and Southcross Boulevard, and the construction of a hike-andbike trail between Pyron Avenue and VFW Boulevard. The work is projected for completion in late 2004. Package 4 will be undertaken in the future and will involve the installation of hike-and-bike trails between Mitchell Road on the south end and East Market Street on the north end.
An additional component of this phase will be the installation of a hike-and-bike trail between Lone Star Boulevard and South Alamo Street. Only the first four phases of the project include archeological investigations. Package 5 will consist of the installation of signage and markers along the length of the project. Because the project is estimated to last several years, rather than waiting for the completion of the entire project before issuing the report of findings, each volume issued in this series will report on the findings of a specific package or closely related packages.

\section{Project Description}

On October 8, 1998, CAR contracted with the City of San Antonio to provide additional archeological services to assess damage done by unmonitored construction activities to areas surrounding Mission San Francisco de la Espada, southernmost of the five Spanish Colonial missions in San Antonio Texas (Figure 1-1).

CAR's original involvement with the Mission Trails Project (MTP) was intended to provide archival research and monitoring of all construction activities in areas of the project that had the potential to impact cultural resources eligible for inclusion in the National Register of Historic Places or for designation as State Archeological Landmarks. In particular, a qualified archeologist was to be present during construction work in areas already known to contain significant cultural resources, referred to as Historically Sensitive Areas (HSA), to ensure that important cultural deposits could be identified immediately and plans made to avoid or mitigate damage to such deposits. All archeological investigations were to meet the Secretary of the Interior's Standards and Guidelines for Archaeology and Historic Preservation and were to be performed under an Antiquities Permit from the Texas Historical Commission.

According to the scope of work for the project, TxDOT and the City of San Antonio were to provide 48 hours notice before construction in all HSA job sites was to begin, so that $\mathrm{CAR}$ could have a qualified archeologist at the site during the construction. However, before an Antiquities Permit had been issued to CAR, extensive construction work was carried out in the vicinity of Mission Espada without 


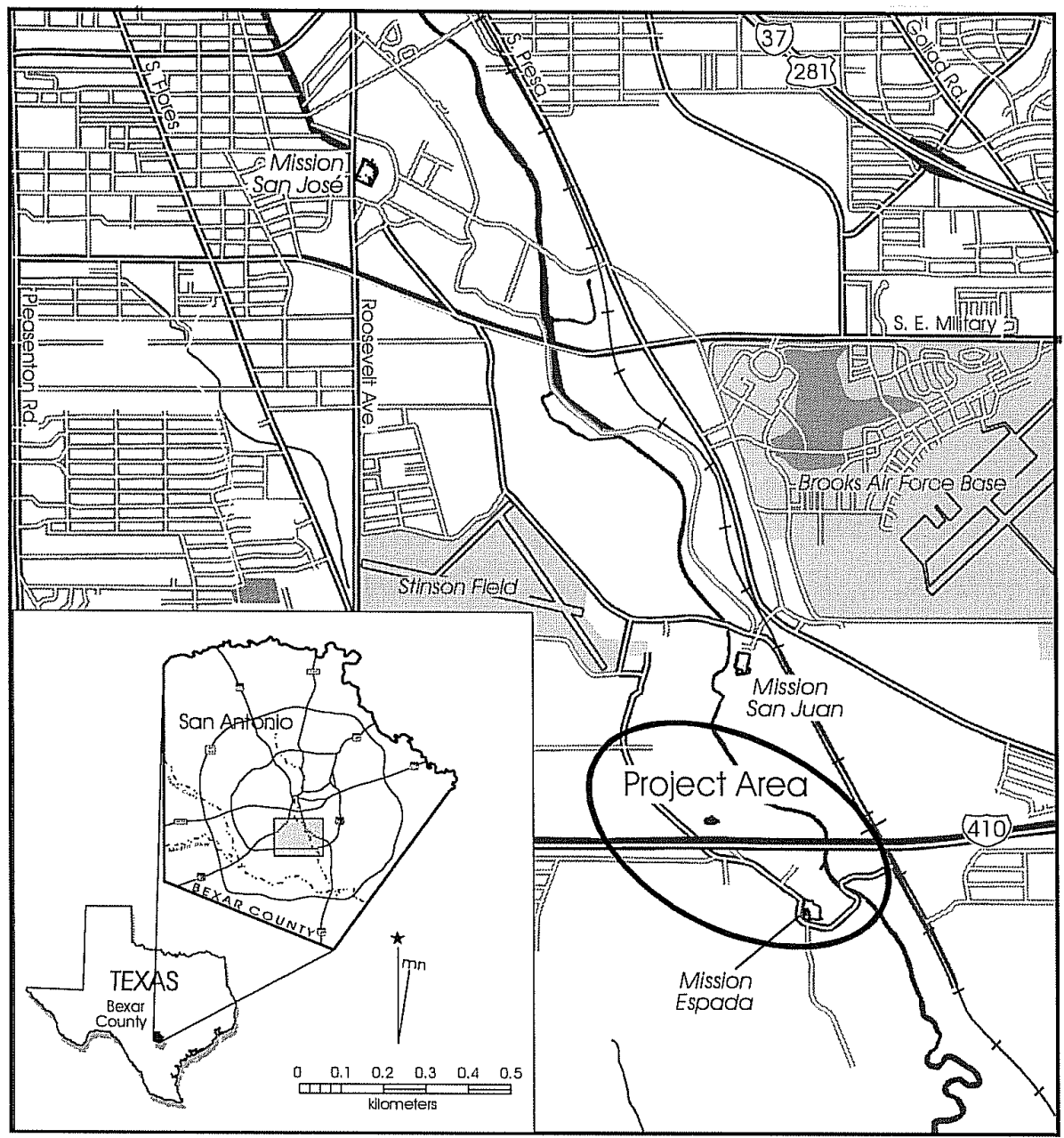

Figure 1-1. Map of south San Antonio showing project location.

prior notification to CAR. When staff from the City of San Antonio Historic Preservation Office learned of these activities, work was halted and the extent of the unmonitored activities was assessed at follows:

Drainage System A: A trench for a drainage pipeline had been dug to Espada Road and new pipe laid in this trench. Two apparently intact archeological deposits/features were observed near Espada Road. The first consisted of brick and oxidized clay soil, which appeared to be a Colonial-period kiln. The second appeared to be a prehistoric deposit consisting of fire-cracked rock, bone, and lithic artifacts.
Drainage System B: The existing ditch had been cleared. Plans called for this channel to be widened by 20 feet.

The western half of the Hike-and-Bike Trail adjacent to the west wall of Mission Espada had been graded to approximately six inches below original ground surface, impacting a Colonial-period trash midden.

In order to assess damage to cultural resources already done and to mitigate further damage, the City of San Antonio, the Texas Historical Commission, TxDOT, and CAR agreed to the following: 
Drainage System A: In order to expedite the construction project, monitoring of the excavation of the remaining section of pipeline trench in Espada Road was to be coordinated with construction crews as soon as possible. Second, archival research would document the historic nature of the entire area impacted by Drainage System A. Third, CAR would excavate a series of backhoe trenches along the already disturbed portion of the drainage system in order to identify any undisturbed archeological occurrences, such as the kiln and prehistoric deposit described above, that survived construction excavation. Approximately six 1-x-1-m units were to be dug to assess already identified features along this portion of the drainage system.

Drainage System B: The existing ditch would be checked by an archeologist for evidence of exposed archeological materials. CAR archeologists would excavate ten backhoe trenches along the length of the planned widening of the ditch in order to locate any still-buried archeological deposits/features.

Hike-and-Bike Trail: In the area adjacent to Mission Espada, the construction of the trail would remove approximately six inches of what appeared to be intact Spanish Colonial midden deposits. A portion of these sediments had already been removed by the construction project. In order to mitigate further damage to the midden, $1550-\mathrm{x}-50-\mathrm{cm}$ test units would be excavated to record the stratigraphy of this feature, look for possible architectural remains, recover a reasonable artifact assemblage, and assess the affect of the previous impact to this feature. Unfortunately, communication failures were still a problem. During the early days of the excavations along the Hike-andBike Trail, while the crew from CAR was not present, the gateway entrance was graded without monitoring by an archeologist. The purpose of the grading was to make the parking lot north of the church accessible to parishioners. However, 8-12 inches of sediments and old roadbed were removed, partially exposing Colonial-period foundations. As a result, the scope of work was modified so that more units would be located in and near the southern part of the northwest gate area, where architectural remains were most likely to be present. The remaining units were to be spaced at regular intervals northwards within the trail footprint. Additional 1-x-1-m units would be excavated if deemed necessary.
Espada Acequia: CAR would monitor replacement of the old reinforced concrete pipe with a sleeve pipe in the acequia with the intent of documenting the acequia at this location.

Between December 1998 and April 1999, CAR performed the archeological investigations described above, under Texas Antiquities Permit No. 2051. A total of 49 units was excavated in three areas designated as the Hike-and-Bike Trail, the Northwest Gateway and Drainage System A. In addition, excavation by construction crews in Drainage Systems A and B and replacement of pipes within the Espada Acequia was monitored.

\section{Project Location}

Mission Espada is located about nine miles south of the center of San Antonio on the west bank of the San Antonio River (Figure 1-1). It is the southernmost of the San Antonio missions, located on a high terrace over the river. A wellbuilt dam near the mission fed a complex system of acequias that watered the mission fields. The dam is still intact and diverts water from the river into an acequia carrying water to the fields near the mission. A number of other acequias that once also watered the surrounding fields still exist, but are no longer in use (Figure 1-2).

\section{Environmental Setting}

The climate of the region is subtropical and subhumid, with mild winters and warm to hot summers (Taylor et al. 1991). January highs average $60.8^{\circ} \mathrm{F}$ and lows average $37.9^{\circ} \mathrm{F}$. July highs average $95.0^{\circ} \mathrm{F}$ with lows of $75.0^{\circ} \mathrm{F}$ (Bomar 1999:214 222). The growing season at San Antonio averages about 267 days a year (Bomar 1999:214-222).

Bomar (1999:228-230) notes that normal annual precipitation at San Antonio is 30.98 inches, with a bimodal distribution during the year. The first peak occurs in May and June and the second occurs in September and October. The driest period of the year is between December and March, when precipitation averages roughly 1.64 inches per month. However, precipitation averages mask the extreme variability of rainfall amounts from year to year in the region. Precipitation has varied from a high of 52.28 inches in 1973 to a low of 10.11 inches in 1917 (Bomar 1999:228). This variability displays very little periodicity or trend (Norwine 1995:143). 
Bexar County is located at the juncture of three major physiographic regions: the Edwards Plateau in the north and northwest parts of the county; the Blackland Prairie in the east-central; and the Gulf Coastal Plain in the south. The Gulf Coastal Plain, within which the project is located, is associated with the Tamaulipan Biotic Province which has been dominated by savannah and grasslands during the historic period (Potter et al. 1995:23). Soil at the site is described by Taylor et al. (1991) as Frio Clay Loam which occurs on the floodplain and low terraces bordering the floodplain of the San Antonio River, and is considered fairly productive (Taylor 1991:16).

The environmental setting of the upper San Antonio River Valley satisfied the immediate needs of the Spanish Colonial missions. Water, food, fuel, building materials, and fertile soils were abundant, as well as game animals, fish, fruits and nuts, and plant species useful for medicinal purposes. The fact that the river channel was not deeply eroded allowed easy access for irrigation.

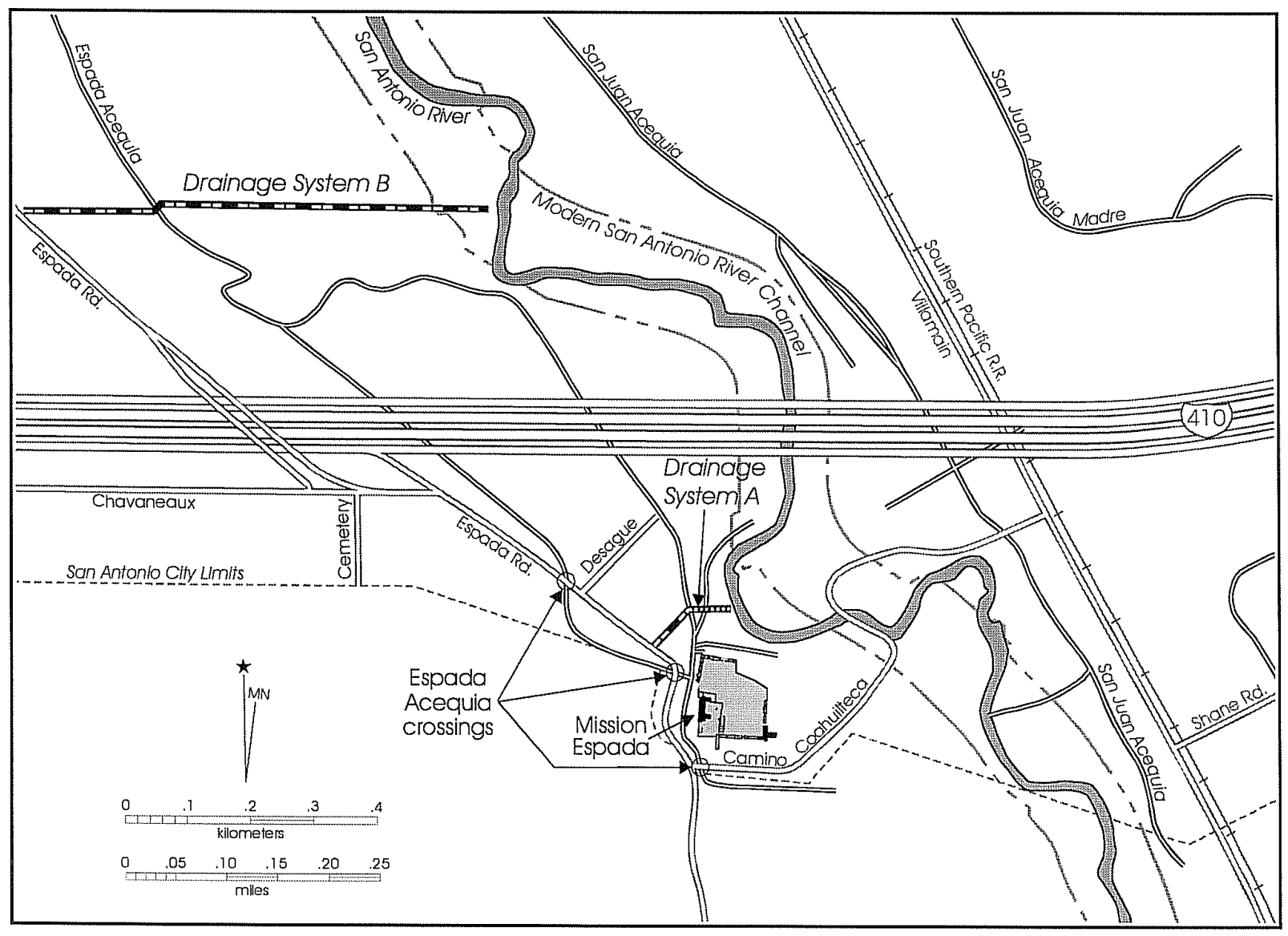

Figure 1-2. Map of region around Mission Espada, showing the old and current course of the San Antonio River; roads, acequias, and location of Drainage Systems $A$ and $B$. 


\section{Research Issues}

As part of this report, the following research issues will be addressed:

What is the age of the midden deposit along the west wall of the mission?

Is the midden the result of general trash discard, or is it associated with a specific activity (such as butchering, etc.)?

Was the trash discarded in a pit or was it discarded as a sheet deposit?

Are patterns of artifact dispersal apparent? If so, what can be inferred from such patterns?

How is the midden related to the nineteenth-century houses known to have been placed along the wall?

To what extent are post-Colonial artifacts mixed with Colonial artifacts? Have construction activities, especially the twentieth-century reconstruction of the walls, impacted the midden?

Was the brick feature observed in Drainage System A actually a kiln, and if so, what type of ceramic was fired there? Were a significant proportion of the ceramics at Espada made locally?

\section{Report Structure}

A brief historical background for Mission Espada and the Espada Acequia is provided in Chapter 2. Previous archeological investigations at Mission Espada are detailed in Chapter 3. Chapter 4 describes the methods and procedures followed in the field and in the laboratory during the project. Chapter 5 presents the results of the excavations and monitoring and Chapter 6 provides detailed descriptions of artifacts recovered during the project. Chapter 7 discusses the information provided in the previous two chapters in relation to the research issues described above. Chapter 8 provides a summary of the project. 



\section{Chapter 2: Historic Background}

The following is a very brief history of Mission Espada. A more detailed history is available in Habig (1968), while more detailed architectural histories can be found in Ivey et al. (1990) and Zapata et al. (2000).

\section{Mission San Francisco de la Espada}

The mission that became Mission San Francisco de la Espada was originally established in 1690 for the Tejas Indians in East Texas. The establishment of the mission was in conjunction with the fifth expedition into Texas by the governor of the Province of Coahuila, Alonso de León (Foster 1995:33). León, along with Fr. Damian Massanet and three other friars from the Apostolic College of Querétaro established the mission on May 24, 1690, about seven miles west of the Neches River on San Pedro Creek, in what is now Houston County (Habig 1968:192). This mission was abandoned in October of 1693 and was not reestablished until July 1716 , when it was relocated about 10 miles to the east on Bowles Creek (now in Cherokee County) and renamed Nuestro Padre San Francisco de los Tejas (Habig 1968:195). This mission failed in the summer of 1719 when the French drove the Spaniards out of East Texas.

In August of 1721, the mission was re-established on the same Bowles Creek site and renamed San Francisco de los Neches by the expedition of the Marqués de Aguayo, with the assistance of a detachment of Spanish soldiers and Fr. José Guerra. In 1729, the College of Querétaro decided to relocate its three East Texas missions to San Antonio. The moveable property of Mission San Francisco de los Neches was relocated to the west side of the San Antonio River on March 5, 1731, and the mission was renamed San Francisco de la Espada (Habig 1968:202-204).

Mission Espada is the southernmost of the five SanAntonio missions and was thus the most susceptible to attack from raiding Indian groups. Frequent raids by such groups continued throughout the early years of the mission. Despite these depredations, the missionaries and neophytes persisted and a small frontier settlement emerged.

The earliest census for Mission Espada was recorded in 1737 and the population numbered 108 (Zapata et al. 2000:5). Between 1737 and 1740 , the average adult population was
73. The highest census recorded lists 207 individuals in 1762, with a low count of 24 in 1809 . Between 1745 and 1777 , the highest average adult population for this mission was 127 , however, the mission population fluctuated considerably between 1737 and 1809 , with a $50 \%$ decrease between $1789(n=93)$ and $1790(n=46)$. Although this extraordinary decrease was evident at all five missions, this decline was owed to a bureaucratic problem rather than some calamity. Schuetz (1980:191-95) attributes this decrease to a change in the reporting criterion of the 1790 census, which required that only those Indians actually living inside the mission walls be included in the census. It is possible that by the late-1780s, at least half of the neophytes were living outside the mission walls (Zapata et al. 2000:4).

The principal enterprises in which the neophytes, as directed by the friars, were engaged while at the mission included farming and ranching, construction and maintenance of an elaborate irrigation system, and the construction of numerous masonry structures, outbuildings and other building projects (see Almaráz 1982; Escobedo 1984; Habig 1968; Ivey et al. 1990).

\section{The Mission Compound}

The early mission structures were jacales, small buildings constructed by plastering a small rectangular palisade of poles and twigs with mud and adding a thatched roof (for a detailed discussion see Graham 1978:38-45). These were designed as temporary housing, but according to Schuetz (1980:244-245), the missionaries at Espada were never able to construct enough stone housing for their neophytes.

When Mission Espada was established in 1731, the Indian quarters consisted of jacales grouped into a small village with the acequia running through it (Ivey et al. 1990:201). In 1745, Fr. Ortiz reported that the Indian quarters running along the northwestern margin of the mission compound were still jacales grouped around the church (Habig 1968:208). It was not until the mid-1740s that any substantial structures were recorded as being present at Mission Espada. In his 1756 report, Fr. Ortiz stated that work had begun on enclosing the mission with a stone wall, probably as a defense against bands of Native American raiders, and work had begun on building stone houses against the wall (Habig 
1968:211). It was probably about this time that the west wall houses were built and first occupied. A 1762 report described the Indian houses as built of stone and mortar, forming three rows around the mission square (Habig 1968:213). Later reports, up until 1789, continued to describe the Indian houses the same way.

The church at Espada was never fully completed but master mason, Antonio de Tellos of Zacatecas, supervised the partial construction of the sacristy, which was then put into use as a temporary church. De Tellos could not complete the building because he murdered his girlfriend's husband and was forced to flee from San Antonio (Cox 1995; see also Ivey et al. 1990). Without the master mason, the friars were never able to finish the church. The sacristy became the functioning chapel of Espada and has maintained this use to the present (Figure 2-1).

\section{Secularization}

Partial secularization of the San Antonio missions occurred in 1794, and full secularization in 1824. Over the course of this 30-year period, Mission Espada's population decreased considerably, and ownership of the remaining structures went into private hands (Almaráz 1982).

The 1824 inventory associated with the final secularization noted that a few buildings were intact and still in use, but the chapel and friary were in poor condition and, at a minimum, lacked roofs. This same inventory listed most of the mission property in terms of ox-cart loads of stone. The local city council viewed the former missions as sources of reusable construction material, suitable for favored citizens (Almaráz 1982).

\section{Father Bouchu}

The arrival of Fr. Francis Bouchu in San Antonio in 1858 signaled the rebirth of Mission Espada, as he took particular interest in the mission. Father Bouchu (b. 1829 - d. 1907) resided at Mission Espada for approximately 40 years, beginning in 1867 (Habig 1968). According to Habig (1968) and Ivey et al. (1990), he was the person most responsible for the restoration, adaptive reuse, and reconstruction of the mission's Spanish Colonial fabric. The deed records show that Fr. Bouchu bought the property on which the church and convento stood from Gregorio Casillas in 1868 (Ivey et al. 1990:313). In addition to purchasing mission property, Fr. Bouchu purchased several other properties adjoining the mission (Almaráz 1982). These properties were all purchased with personal funds and under his name. In his personal ledger, Bouchu made a conceptual drawing of the friary, kitchen, and dining room. Beneath the drawing, on the same page, are ledger entries for 1867, 1868, and 1869 for the purchase of building materials and for payments to brick makers, carpenters, and masons. From this information, it can be assumed that the convento structures, with the exception of the chapel, underwent various changes, between 1867 and 1869. Reconstruction of the chapel was not begun until ca. 1884, and may have been completed by ca. 1887 (Ivey et al. 1990). By 1890, William Corner (1890:23) observed that several families still resided in "tumble-down huts on the lines of the Mission square," suggesting that the perimeter wall was no longer apparent. During this period, parts of the old convento were used as a store (Zapata et al. 2000:9).

\section{The Mission Post-1907}

After the death of Fr. Bouchu in 1907, the mission was placed under the care of the Claretians, and the chapel fell into disuse from 1909 to 1915 . Beginning around 1916, the diocese handed over responsibility of the mission to Fr. William Hume. With diocesan support, Fr. Hume was able to carry out some reconstruction of the Espada chapel (Thurber et al. 1993).

During the twentieth century, a school, run by the Sisters of the Incarnate Word, was opened in one of the mission buildings and continued in operation until 1967. The chapel was alternately closed and restored several times, and in 1930 to 1932 and 1955 to 1956 restoration work was carried out on many of the other buildings. In 1936, the Historic American Buildings Survey (HABS) photo-documented all the San Antonio missions (Thurber et al. 1993). On February 20, 1983, Mission Espada and three of the other San Antonio missions were combined into the San Antonio Missions National Historical Park, administered by the National Park Service (Cruz 1983).

\section{The Houses on the West Wall}

When the mission was secularized in 1824, an appraisal of the houses at the mission (Mission Records [MR] 62-70 1824) lists each house still standing, its condition, and the value of the rock on the property including the houses and the remaining mission wall (Figure 2-2). When the appraisal progresses around to the west wall, it reads as follows: "10 rooms; 48 varas of walls which are useless; roofless; 


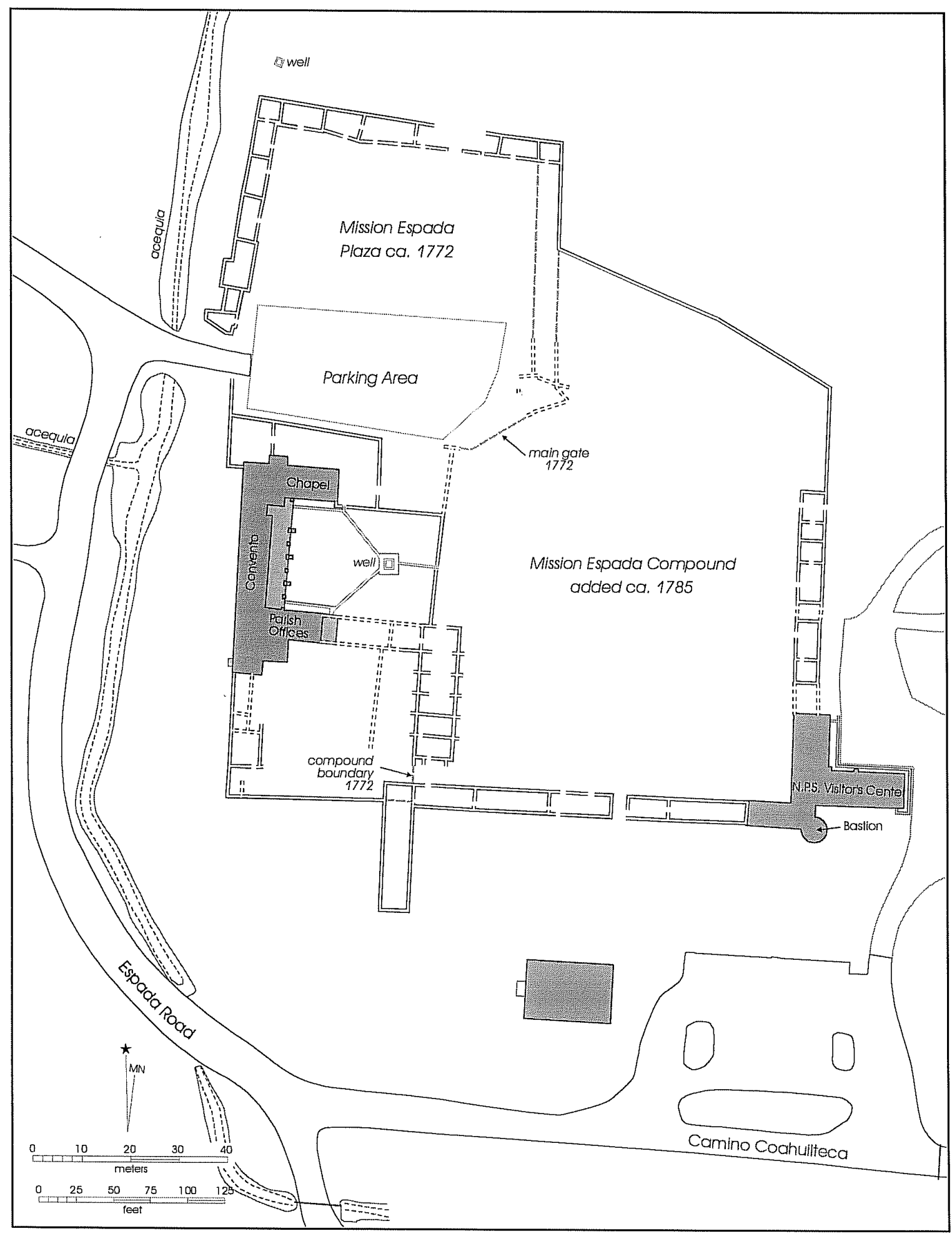

Figure 2-1. Plan map of Mission Espada. 
estimated at 160 ox-cart loads of rock" valued at 2 reales per vara (MR 65 1830). The land within the mission was divided into individual lots and occupied by "the native residents and their sons, and by the old residents of the secularized mission" (MR 65 1830:1). On the west wall, each house lot extended from the front of the house on the edge of the plaza to the acequia that ran about 15 varas to the west (Figure 2-2). By 1827, all but two of the lots contained a jacal (often called a "shack" in nineteenthcentury records) built in front of or against the stone perimeter wall in place of the original stone Indian house that stood there before 1789 (MR 65 1830:9-11). The other two lots were vacant except for the section of the perimeter wall included in the lot boundaries. It appears that the original mission wall had survived up to this time, at least from the gateway to the northwest corner.

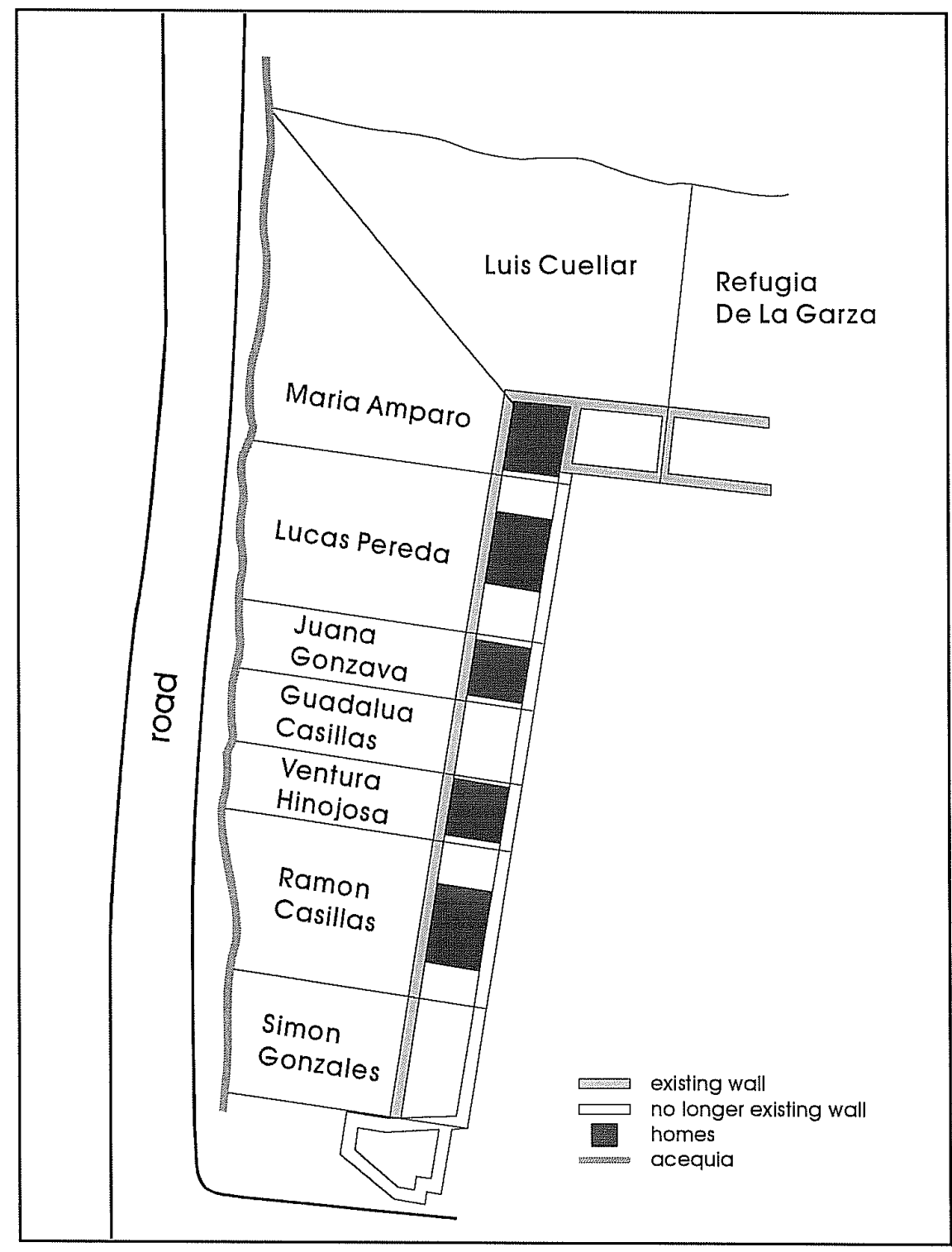

Figure 2-2. Map of the west wall of Mission Espada, north of the Northwest Gateway, showing property ownership and jacal structures present, 1824-1827 (based on Mission Records). 
A 1936 photograph shows a two-room rubble-stone house with a flat roof on the second lot north of the gateway, which had been granted to Ramon Casillas after secularization (MR 65 1830:9). This property, along with those on either side of it, appears to have been acquired by Fr. Bouchu in 1883 (Bexar County Deed Records Vol. 26:282). He may have built the stone house about that time, replacing the jacal present on this lot in 1827 and utilizing material from the stone ruins of the earlier Indian houses. A plat attached to the deed transferred these lots to Rev. J. W. Shaw at the death of Fr. Bouchu (Bexar County Deed Records Vol. 423:130). A 1956 map made by surveyor F. T. Drought (Drought 1956) indicates that at that time only one structure remained standing on the west wall just north of the gateway, which would have been the one in the 1936 photograph.

\section{A Brief History of the Espada Acequia}

The acequia for Mission Espada began at a dam spanning the river, midway between missions San José and San Juan, diverting water into a channel along the western side of the river. This dam, the last of the functioning Spanish Colonial dams, is constructed of limestone and lime mortar, and arches downstream of the river flow. At a point 1.49 miles below the dam, it became necessary to construct an aqueduct to convey the water over Piedras (Six-Mile) Creek. This aqueduct remains as the only surviving stone aqueduct from the Colonial period. It was described in 1772 as a "...conduit of lime and stone of thirty-eight varas [105.5 ft.] in length; six [16.6 ft.] in height; with its diamond point, and two arches, which allow the currents of said creek to pass..." (Sáenz de Gumiel 1772). The diamond point referred to is the pointed projection of the central pier that diverted the pressure of the stream away from the support for the two arches.

The acequia continued south to the mission and below for a total length of approximately $31 / 4$ miles. At a point a short distance above present Interstate 410 , the acequia branched, the northern branch watering fields near the river and the southern branch roughly followed Espada Road and fed laterals to the south and southwest. The two channels converged at a double stone gate near the northwest corner of the mission compound (see Figure 1-2). By 1913, the urban acequias of San Antonio were all closed because their cost has exceeded their usefulness. Although the San Juan and Espada acequias continued to irrigate the fields below the city, as they had done for more than two centuries, they were operated by private ditch companies and were not in the public eye. In 1936, the San Antonio Conservation Society began efforts to raise funds to acquire the Espada aqueduct from private owners. It was finally purchased by President Elizabeth Graham from her private funds. In 1937, upon her retirement, she presented it to the Society (Fisher 1996:168; San Antonio Express 1939).

In the 1950s, the proposal by the Corps of Engineers and the San Antonio River Authority to rechannelize the river for flood control below the city threatened to terminate the last two Spanish irrigation systems. This resulted in the property owners who were utilizing the waters of the ditches filing suit to prevent this denial of water guaranteed by their original grants. This resulted in counter suits by the River Authority, and after several court decisions, the Texas Supreme Court found in favor of the landowners. Although the new channel bypassed both dam structures, it deepened the channel to a depth that deprived them of their source of water; therefore, to restore their flow it was necessary to construct two concrete dams to raise the level of the water to a sufficient height to feed the ditches (Hafernick et al. 1989:3). In early summer of 1959, the San Antonio River Authority began construction of a 450 -foot-long dam across the improved channel at a point almost opposite the original dam for the Espada Acequia. This structure was designed to create a pool, 2,000 feet long and seven feet deep, behind the new structure that would allow siphon tubes installed below water level to feed the channel to the old Espada reservoir (San Antonio Light 1959). 



\section{Chapter 3: Previous Archeological Investigations}

This chapter includes a discussion of all archeological projects at Mission Espada since 1976, including those projects that have been completed during and since the project reported here. All projects have been limited in both scope and extent. The following summarizes the major findings of each study. Notations on Figure 3-1 indicate the location of each of the investigations, and are numbered as below.

1. The earliest archeological study of Mission Espada was in May 1976, when CAR excavated three 1-x-1$\mathrm{m}$ units along the exterior and interior walls of the bastion (Fox and Hester 1976). This was a limited study designed to determine the mode of construction of the wall footings, which would aid in the planned stabilization of the bastion. For this purpose, two of the units were located along the exterior east and west walls of the bastion, and the third was located along the interior south wall. The findings of this investigation noted that the wall footing was constructed of " $50 \mathrm{~cm}$ of rubble set in soil, packed into a trench the same thickness as the wall" (Fox and Hester 1976:22). The wall was described as being "constructed of roughly shaped local stone, set in a sand and lime mortar" (Fox and Hester 1976:22). Although Fox and Hester (1976:4) were unsuccessful in establishing a date of construction for this feature, there are references made in historical documents in relation to this bastion from as early as 1772 .

2. In March 1977, Killen and Scurlock (1977), working for the Texas Historical Commission, excavated four kilns located immediately north-northeast of the compound. Only the interiors of the kilns were excavated, and the recovered artifacts were of Colonial and post-Colonial origin. The features were considered to be Spanish Colonial in nature and interpreted as being lime kilns. Due to time constraints, only one of the four kilns was excavated to its final depth, and the adjacent areas were not investigated. These features were backfilled and then capped with corrugated metal sheets for future consideration (Killen and Scurlock 1977).

3. In 1981, CAR conducted archeological investigations of two areas (Area A and Area B). A total of three units was excavated immediately north of the chapel (Area A, Units 1, 2 and 5; Fox 1981). Testing of Area
A was designed to identify and document cultural features and/or deposits, in order to make way for a caliche-paved parking area. The second area tested (Area B, Units 3 and 4) was designed to document an early-twentieth-century building, referred to as either the Oaks House or the Old Convent. This area is located on the eastern, exterior wall of the compound. Fox concluded that the proposed parking area (Area A) would not impact the mission's cultural resources, but did suggest future improvements in this area be limited to raising the present grade of the caliche gravel, rather than cutting into it (Fox 1981:7). Fox located a minimal amount of architectural evidence of the Old Convent and proposed that future development of Area B would not impact the mission's cultural resources (Fox 1981:7).

4. In 1983, CAR conducted archeological monitoring of coring activities and a limited test excavation (Fox 1999). Five core drills were located within the immediate vicinity of the convento, and a sixth was placed at the exterior northwest corner of the mission compound. The core drilling and limited test excavation was designed to secure subsurface information in connection with wall stabilization efforts. The results of the cores noted dark loamy and clayey soils to about $3 \mathrm{~m}$ below surface, and then caliche to about $6.1 \mathrm{~m}$, at which point water was reached. The $3-\mathrm{ft}$. by $5-\mathrm{ft}$. (0.9-x-1.5-m) test trench was located along the west perimeter wall of the compound, just south of the chapel. The excavation located the bottom of the wall at about $1.2 \mathrm{~m}$ below surface. The wall footer extended between $1.2 \mathrm{~m}$ and $1.6 \mathrm{~m}$ below surface. The results of the excavation did note that various stages of wall collapse and rebuilding had occurred in this area (Fox 1999).

5. Prior to initiating a structural stabilization project, the National Park Service excavated two rooms to the north and west of the bastion (Escobedo 1984). Escobedo's investigation included extensive archival research and an abstract of the property. These excavations were designed to define the nature of the rooms and to identify any Colonial-period features. One trench and six test pits were excavated in the interior of the North Room (Casanova Room), and 
one test pit was excavated inside the West Room (Diaz Room). The most significant find was the location of flagstone paving in the West Room, which was presumed to be Colonial period in origin. Escobedo (1984) concluded that the rooms were probably constructed ca. 1785 and that, contrary to Fox and Hester (1976:4), the bastion was constructed ca. mid1820s. Escobedo (1984) also suggested that the mission was constructed in phases and that the southeast section represented the last construction phase.

6. In October 1990, CAR excavated three units within the southeast corner of the compound (Meskill 1992). One of these units was located within the plaza away from any structures, while the other two were placed along the walls of the structures. Testing in the structure area was designed to examine foundations and determine the extent of Spanish Colonial and Mexican period cultural fill. A twentieth-century concrete foundation was exposed beneath the east wall at Unit 1 , and a Spanish Colonial stone-rubble foundation was located against the south wall at Unit 2. Testing within the plaza (Unit 3) resulted in the location of a loose stone alignment, which was attributed to a previously recorded low-lying wall. The results of these excavations indicate that a portion of the original foundation along the east wall was modified ca. 1930 . The wall footer along the south wall extends approximately $50 \mathrm{~cm}$ below the actual depth of the wall construction. The wall alignment exposed within Unit 3 , with a north to south orientation, was located at approximately $10 \mathrm{~cm}$ below surface. Excavation of Unit 3 ceased at $45 \mathrm{~cm}$ below surface and was determined to be culturally sterile at that point. Meskill (1992) did caution against any below-grade disturbances being conducted in this area of the compound.

7. In October 1996, in advance of a proposed movie set construction, CAR executed a series of shovel tests within the area known as the New Plaza (Gross 1997). A total of 26 shovel tests was placed at $50 \mathrm{ft}$. intervals within a $200 \mathrm{ft}$. by $300 \mathrm{ft}$. area (see Figure 3-1). Based on the recovered cultural material, the results of this testing suggest an earlier occupation or use of the north end of the plaza. The occurrence of Colonial-period artifacts and bone fragments at the north end was much greater than that at the south end. As a result, Gross suggested that the north end of the New Plaza may contain intact Spanish Colonial deposits, and that this area should be avoided until after the proposed 6 to 12 inches of fill was added.
8. In April 1998, CAR monitored the excavation of a 10-inch-wide by 18-inch-deep hand-excavated trench along the outside of the west wall, and along the south end of the Priest Quarters and parish office (Meissner 1998a). This trench was excavated in order to install a below-grade electrical conduit. Monitoring of this activity resulted in the collection of a small sample of diagnostic artifacts and the recording of noted cultural features. As a result of locating a wall foundation, as well as large fragments of animal bone and ceramics, Meissner cautioned against any future excavation in this area. The wall foundation was located about eight feet east of the reconstructed north-south perimeter wall, and a high density of Spanish Colonial ceramics were also located in this same general area (Meissner 1998a).

9. Also in 1998, CAR performed archeological excavations at Mission Espada prior to the installation of electrical lines in the convento of the mission. These investigations consisted of a $1-\mathrm{x}-2-\mathrm{m}$ unit dug along the southwest corner of the Priest Quarters, in the same area monitored by Meissner (1998a) earlier that same year. The results of this work were included in a report detailing the outcome of investigations conducted at Mission Espada in July and August 1999 (Zapata et al. 2000).

10. In July and August 1999, CAR investigated the area along the southern walls of the Priest Quarters (Zapata et al. 2000). Fourteen 1-x-1-m units were dug. This work was conducted in advance of the installation of foundation piers and beams as part of a wall stabilization project. These excavations exposed a $25.2-\mathrm{m}$ section of the wall foundation and recovered a variety of Colonial and post-Colonial artifacts including ceramics, lithics, glass, metal, chipped stone, and animal bones.

11. In addition, in July of 1999, CAR staff shovel tested along the route of an electrical utility trench designed to provide the mission with upgraded utilities support in connection with the first phase of the Mission Trails Underground Conversion Project (Tennis 2001). Shovel testing began along the route of the trench at a point adjacent to the southwest corner of the mission compound and progressed to the center of the acequia on the north (see Figure 3-1). Monitoring of the trench excavations began at the same time and continued until the project's completion. The shovel testing and 
monitoring revealed that the area along the route of the trench has been extremely disturbed by the construction and installation of a septic field. Monitoring of the dry channel of the acequia revealed no early historic deposits (Tennis 2001:116).

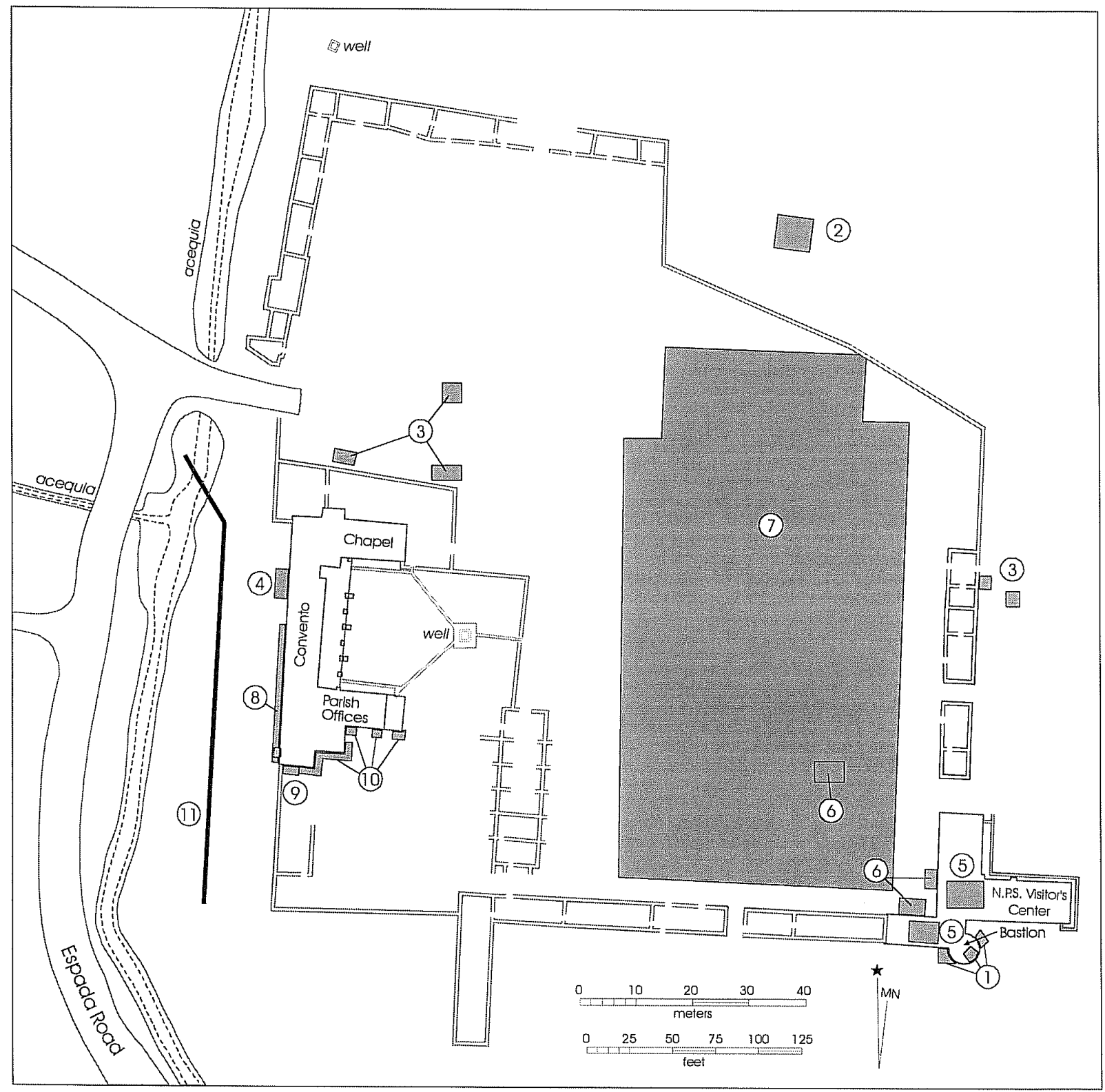

Figure 3-1. Locations of previous investigations: 1) Fox and Hester 1976; 2) Killen and Scurlock 1977; 3) Fox 1981; 4) Fox 1999; 5) Escobedo 1984; 6) Meskill 1992; 7) Gross 1997; 8) Meissner 1998a; 9) Zapata et al. 2000 (1998 work); 10) Zapata et al. 2000 (1999 work); 11) Tennis 2001. Note: Areas of previous investigations are generalized, and not to scale with actual units excavated. 


\section{Chapter 4: Methods}

\section{Field Methods}

\section{Monitoring}

Monitoring of trenching and pipe placement in the area of Drainage System A and Drainage System B, and the replacement of pipe in portions of the Espada Acequia followed standard procedures. Once CAR had been notified of construction activities, a qualified archeologist was present whenever construction workers were digging in these areas. The archeologist observed all digging and made detailed notes of the progress of the trenching. Possible cultural deposits were observed closely, although in this case none were identified as being of historic importance. Photographs were taken to record the process.

\section{Excavations}

The purpose of the test units excavated during this project was to assess damage already done to cultural resources near Mission Espada, and to mitigate further damage that would be necessary to complete the Mission Trails Project. Placement of the test units in the Drainage System A area was based on observation of cultural features in the trench that had been excavated without monitoring by CAR. Four $1-\mathrm{x}-1-\mathrm{m}$ test units and one $1-\mathrm{x}-0.5-\mathrm{m}$ test unit (designated TU 32, TU 33, TU 43, TU 46, and TU 49, respectively) were excavated in order to uncover and evaluate the brick feature (Figure 4-1). Two 1-x-1-m units (designated TU 34 and TU 35) were placed to evaluate the possible prehistoric deposit southwest of the brick feature, and two backhoe trenches (designated BHT 1 and BHT 2) were completed between these two sets of test units (Figure 4-1).

The original field efforts were to consist of the excavation of $1550-\mathrm{x}-50-\mathrm{cm}$ test units (TUs 1-15) along the proposed Hike-and-Bike Trail to determine the degree to which the unmonitored construction work had damaged the Colonial midden located outside the west wall of the mission, and to mitigate any further damage to this and any other features within the footprint of the trail (Figure 4-2). However, shortly after CAR staff began fieldwork along the Hike-and-Bike Trail, construction workers graded the driveway from Espada Road into the parking lot inside the mission compound, north of the Chapel. This work was done without prior consultation with COSA or CAR and while CAR staff were not present. One addition $50-\mathrm{x}-50$-cm test unit (TU 16) and $101-x-1-m$ units (TUs 17-26) were placed along the proposed Hike-and-Bike Trail based on artifacts recovered from the original 14 units.

Placement of test units in the Northwest Gateway area was made after the Colonial features accidentally uncovered by grading, as described in Chapter 1, were recognized. One $0.3-\mathrm{x}-1-\mathrm{m}$ test unit (TU 41) and $151-\mathrm{x}-1-\mathrm{m}$ test units (TUs 27-31, TUs 36-40, TU 42, TUs 44-45, and TUs 47-48) were placed in the gateway area (Figure 4-2).

Test units were excavated in 10-cm arbitrary levels using shovels and trowels. With the exception of samples set aside for processing by flotation, sediments were dry-screened through $1 / 4$-inch wire mesh, and all cultural material was collected and brought back to the CAR laboratory. Standard CAR Unit/Level forms were completed for each 10 -cm level excavated within a unit. Information recorded on these forms included field bag number, soil composition and color (Munsell), recovered artifacts, feature descriptions, and Photo Log and Sample Log numbers. Field bag numbers were assigned in the field for artifacts from each unit/level and for each sample, such as floatation samples, collected throughout the day. Bag numbers were recorded on a Master Bag Log along with specific provenience information, type of sample, and number of bags collected.

Flotation samples were collected from Levels 2 through 5 in TUs 17, 18, 20, 21, 25, and 26; from Levels 2 through 6 in TUs 19, 22, and 23; from Levels 2 through 4 in TU 24; from Levels 6 through 9 in TU 34; and from Levels 3 through 13 in TU 35.

In order to provide for a consistent description of the soils in the project area, the project archeologist, independent of the field crew, determined soil color and texture using a Munsell color chart and field definitions for texture for all soils described in this report.

When appropriate, plan maps of units were drawn to scale on a grid on the back of the Unit/Level forms. Profile drawings of most of the units were made on graph paper. In addition, detailed plan and profile maps of architectural 


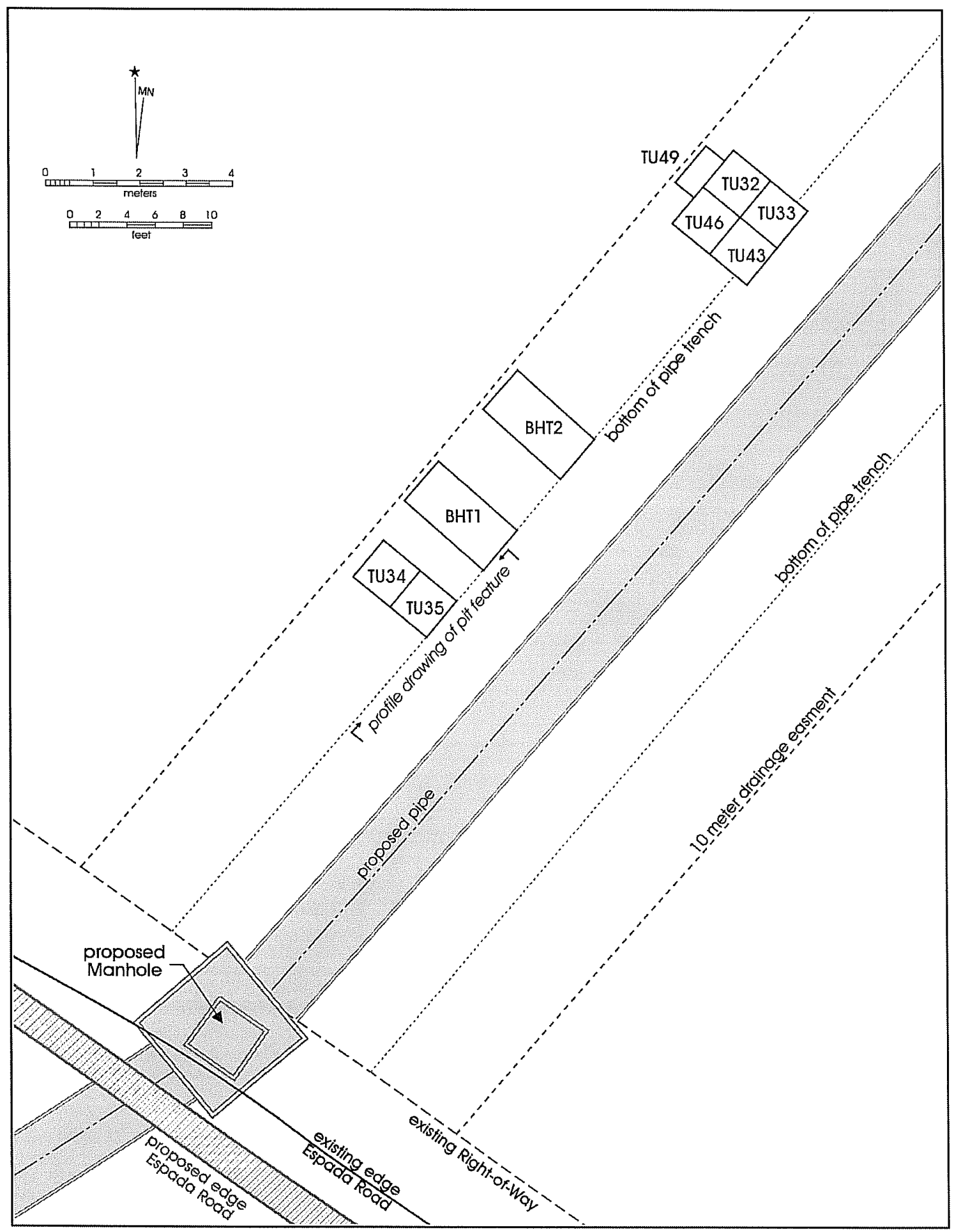

Figure 4-1. Placement of test units and backhoe trenches in Drainage System A. 


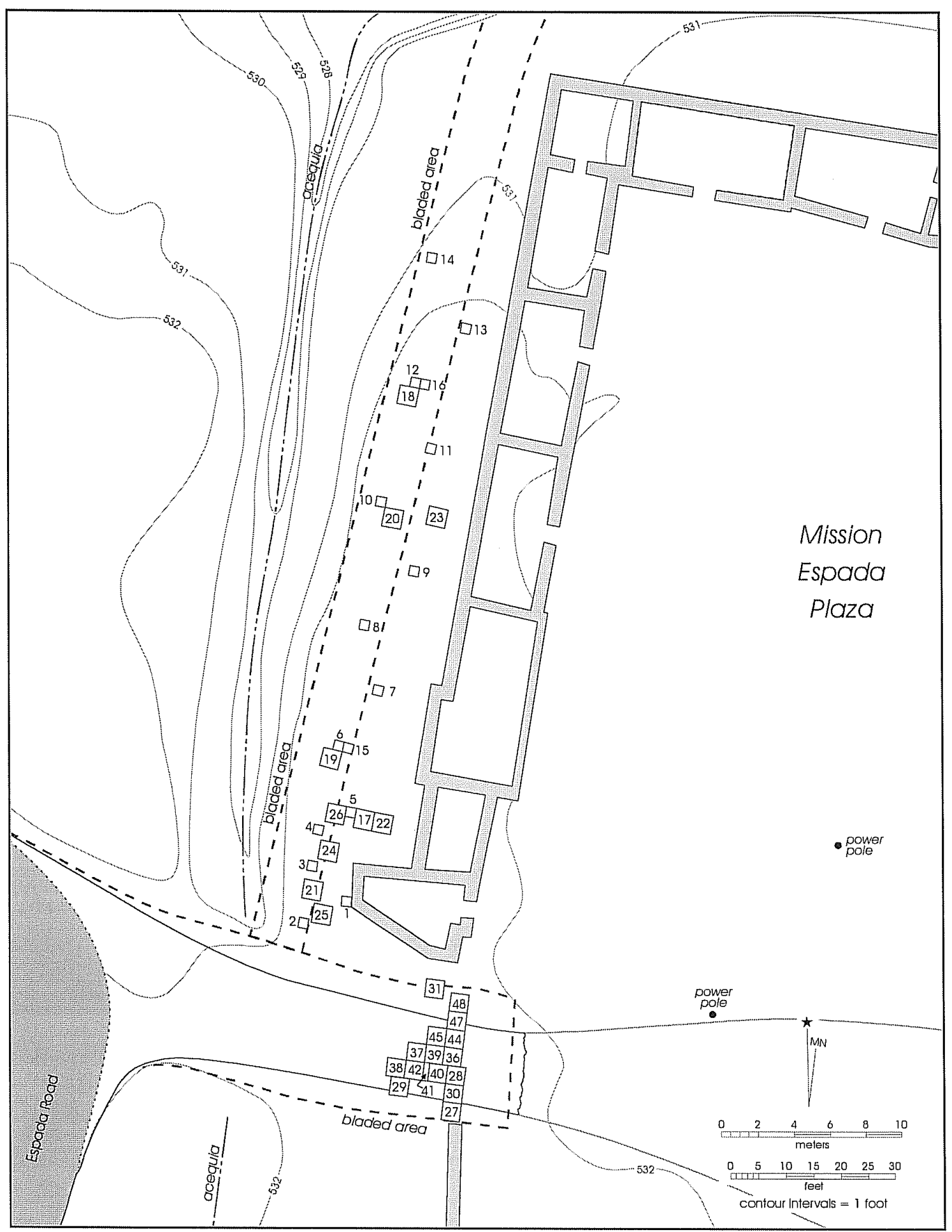

Figure 4-2. Placement of test units in Northwest Gateway area and along Hike-and-Bike Trail. 
features were made. Photographs were taken with Fugi 35$\mathrm{mm}$ and Pentax K 1000 cameras using color print film.

At the end of the field work, the units were backfilled by construction workers with heavy equipment, except the units around the kiln. The kiln area was covered with clean sand and a layer of plywood, then soil was carefully placed on top and graded to match the rest of the Drainage System A ditch.

\section{Laboratory Methods}

Artifact bags were taken to the laboratory on a regular basis and checked against the Bag Log. The contents were washed in tap water and air-dried, keeping careful control of the provenience of each lot. The artifacts were sorted into the classes described in Table 4-1 and cataloged and the results were entered into a database. Artifacts were bagged by Artifact Class/Unit/Level in 4-mil plastic zip-closure bags with acid-free paper tags labeled with provenience information. Each class of artifact was then sent to an analyst. When the analysis of each class was complete, artifacts were boxed by class, and unit/level. The artifacts are permanently curated at CAR.

Table 4-1. Artifact Classes

\begin{tabular}{|c|l|}
\hline Class & \multicolumn{1}{|c|}{ Examples } \\
\hline Kitchen/Household & Ceramics, bottle glass, bottle caps, utensils, etc. \\
\hline Personal & $\begin{array}{l}\text { Buttons and other clothing items, beads and other jewelry, } \\
\text { grooming items, pipes, coins, etc. }\end{array}$ \\
\hline Activities & Toys, games, writing items, etc. \\
\hline Arms & Cartridges, gun parts, etc. \\
\hline Barn/Workshop & Horse shoes, tools, machine parts, etc. \\
\hline Construction & $\begin{array}{l}\text { Nails, other hardware, building materials (brick, tile, window } \\
\text { glass, etc.), utilities. }\end{array}$ \\
\hline Metal \& Other Misc. & $\begin{array}{l}\text { Metal items not included above. Paper, unidentified plastic, } \\
\text { charcoal, coal, clinker, etc. }\end{array}$ \\
\hline Lithics & Stone tools and debitage, ground stone, burned rock. \\
\hline Organics & Bone, shell, seeds, etc. \\
\hline
\end{tabular}




\section{Chapter 5: Results}

Four areas of particular concern were outlined in the scope of work for this project: Drainage System A, Drainage System B, the replacement of pipes in sections of the Espada Acequia, and the Hike-and-Bike Trail near the west wall of Mission Espada. This chapter describes the results of CAR investigations in each of these areas. Artifact tables are included for each area, describing artifacts from each level, with artifacts divided into six dating categories:

Eighteenth Century, indicating artifacts datable to the Colonial period;

Eighteenth/Nineteenth Century, indicating artifacts that were in use in the Colonial period and for some time afterwards;

Nineteenth Century, indicating artifacts, such as most types of white earthenwares, in use only or primarily in the nineteenth century;

Late-Nineteenth/Early-Twentieth Century, i.e., the period between the $1870 \mathrm{~s}$, when the railroad arrived in San Antonio, and World War I, indicating artifacts from that period;

Twentieth Century, indicating artifacts manufactured after 1900 only; and

Not Datable, indicating artifacts that cannot be readily assigned to any of the above categories. The largest item in this category is animal bone, which at least theoretically may have been deposited at any time. Most colors of glass cannot be positively dated (see discussion of glass dating in Chapter 6). Many types of construction-related materials, other than nails, cannot be assigned to one of the date categories above.

\section{Drainage System A}

As described in Chapter 1, prior to the start of archeological excavations in the vicinity of Mission Espada's west wall, a deep trench was dug to install a large drain pipe north of Espada Road, about 18 m east of the mission gate. The pipe was intended to lead from a manhole in Espada Road to the river (see Figure 1-2). By the time the archeologists arrived on the site, a 54-inch diameter pipe had been installed in the trench between the river and a point ca. $20 \mathrm{~m}$ from the edge of the road, and the trench had been backfilled almost to that point. In the section of the trench that was still open, two areas of the trench wall were found to contain possible archeological features.

\section{Pit Feature}

At a location between ca. 10 and $12 \mathrm{~m}$ from the east edge of Espada Road, an anomaly was apparent in the west wall of the trench. Originally, this feature was thought to be a prehistoric site, as lithic materials were observed in the trench wall; however, when the trench profile was cleaned, the feature showed up as a grayish brown sandy loam pit in a yellowish brown/pale brown matrix containing Colonial ceramics. The pit measured ca. $2 \mathrm{~m}$ across at the bottom and appeared to be relatively square in cross-section. At one edge of the bottom were three thin lamellae of different shades of brown clay, suggesting that the pit had been open to the elements long enough to begin to fill with slopewash.

In order to examine the pit fill, two 1-x-1-m units were excavated within the pit, TU 35 at the front and TU 34 directly northwest of it (see Figure 4-1). Fill in the upper seven levels of TU 34 consisted of Colonial ceramics, glass fragments, cut and wire nails, iron scrap, window glass, lithics, and animal bone (Table 5-1). A large deposit of animal bone (1,154 fragments) was encountered in Level 6 . From that level down to the bottom levels, the artifacts recovered were limited to occasional bone and lithic fragments. TU 34 was dug to Level 9, while TU 35 was dug to Level 14 (Figure 5-1).

Two backhoe trenches (BHT 1 and BHT 2) were then excavated into the west wall of the drainage, north of the pit. The intent was to determine whether the pit continued toward the northwest. The stratification recorded in the north and south walls of these trenches showed two distinct strata, a black, crumbly soil containing occasional bone above a stratum of sterile brown sandy clay loam. The south profile of BHT 1 also showed a section of the pit that had been recorded in the west profile of the pipe trench, indicating that the pit was a cubic intrusion into the basal clay and 
Table 5-1. Artifacts Recovered from the Pit Feature (TU 34 \& TU 35) in Drainage System A

\begin{tabular}{|c|c|c|c|c|c|c|c|c|c|c|c|c|c|c|c|}
\hline $\begin{array}{l}\text { Approximate } \\
\text { Dates }\end{array}$ & Artifact Type & Lv. 1 & Lv. 2 & Lv. 3 & Lv. 4 & Lv. 5 & Lv. 6 & Lv. 7 & Lv. 8 & Lv. 9 & Lv. 10 & Lv. 11 & Lv. 13 & Lv. 14 & Totals \\
\hline \multirow{7}{*}{ Colonial } & Goliad ware & & 21 & 11 & 14 & & 35 & 16 & 3 & 3 & 1 & & & & 104 \\
\hline & Other unglazed & & & & & & 2 & & & & & & & & 2 \\
\hline & Majolicas & & 2 & & 2 & & 6 & 3 & & & & & & & 13 \\
\hline & Lead-glazed & 4 & 1 & 1 & 6 & & 5 & 3 & & & & & & & 20 \\
\hline & Piloncillo molds & & & & & & 1 & & & & & & & & 1 \\
\hline & Trade beads \& jewelry & & & & & & $3 \mid$ & 3 & & & & & & & 6 \\
\hline & Lithic artifacts & 7 & 10 & 8 & 2 & & 25 & 12 & 4 & & & & & 1 & 69 \\
\hline \multirow{2}{*}{$\begin{array}{c}18 \text { th/ } \\
\text { 19th Century }\end{array}$} & Olive glass & & 1 & 5 & 1 & & & & & & & & & & 7 \\
\hline & Galera lead-glazed & & 2 & & & & & & & & & & & & 2 \\
\hline \multirow{3}{*}{ 19th Century } & White earthenwares & 2 & 2 & & & & & 1 & & & & & & & 5 \\
\hline & Cut nails & & & & & & 1 & & & & & & & & 1 \\
\hline & Copper luster & & & & 1 & & & & & & & & & & 1 \\
\hline \multirow{4}{*}{ 20th Century } & Clear glass (selenium) & & & 1 & & & & & & & & & & & 1 \\
\hline & Bright green glass & & 1 & & & & & & & & & & & & 1 \\
\hline & Machine-made bottle & & 1 & & & & & & & & & & & & 1 \\
\hline & Wire nails & & 1 & & & & & & & & & & & & 1 \\
\hline \multirow{10}{*}{ Not Datable } & Organics: Bone & 111 & 465 & 239 & 403 & 14 & 1154 & 440 & 136 & 15 & 16 & 21 & 3 & & 3,017 \\
\hline & Organics: Mussel shell & & & 1 & 3. & & 1 & 5 & & & & & & & 10 \\
\hline & Activities & & 1 & & & & & & & & & & & & 1 \\
\hline & Barn/Workshop & & 2 & & & & & 1 & & & & & & & 3 \\
\hline & Construction & 4 & 4 & & 1 & & & & & & & & & & 9 \\
\hline & Kitchen/Household & 16 & 17 & 1 & & & & 2 & & & & & & & 36 \\
\hline & Lithics (FCR) & 5 & 6 & 5 & 1 & & & & & & & & & & 17 \\
\hline & Metal scrap & & 7 & 3 & & & & & & & & & & & 10 \\
\hline & Misc. & 1 & 2 & & & & & 11 & & & & & & & 14 \\
\hline & Totals & 150 & 546 & 275 & 434 & 14 & 1,233 & 497 & 143 & 18 & 17 & 21 & 3 & 1 & 3,352 \\
\hline
\end{tabular}

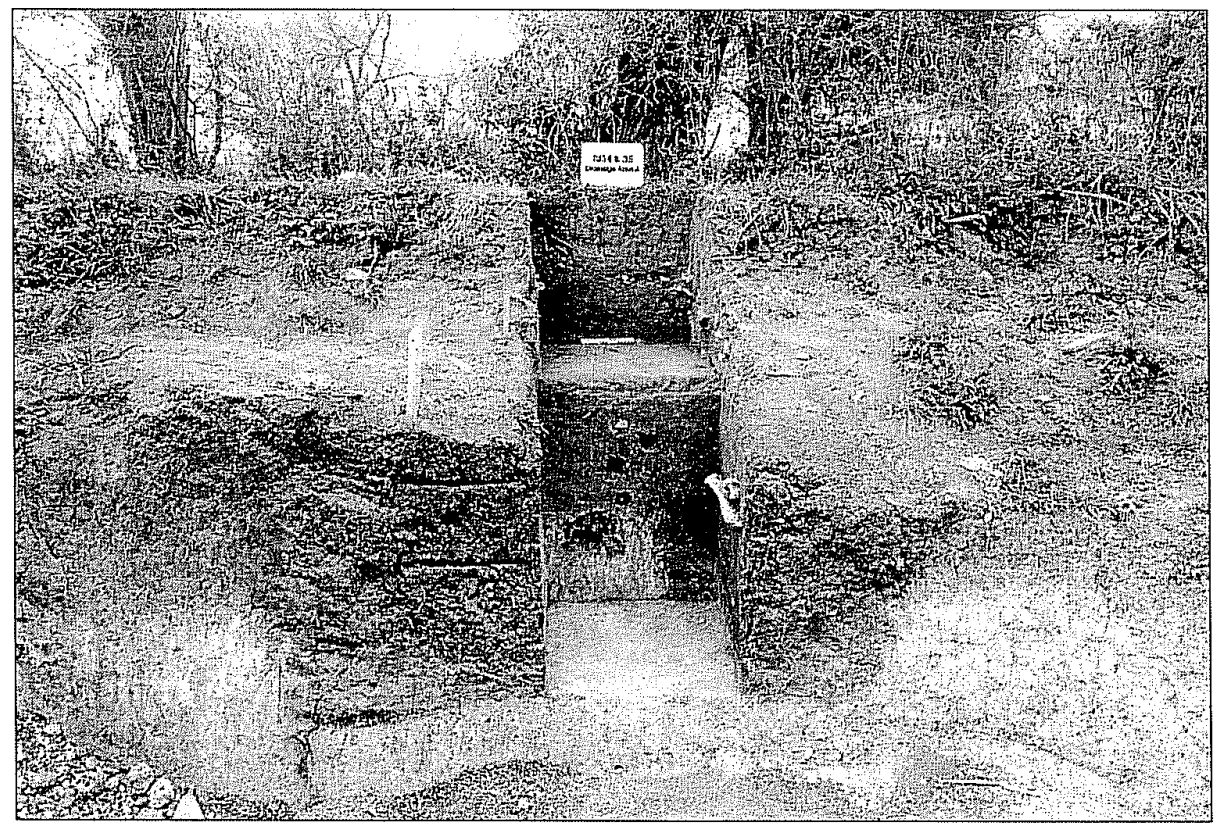

Figure 5-1. TUs 34 and 35, showing pit feature in Drainage System A. 
caliche (Figure 5-2). The pit did not continue far into BHT 1 , and no trace of it was found in the opposite, north wall of the trench. The reason for the pit was not determined, but it appeared that it might have been a borrow pit for clay to be used by the potter, then later used as a trash dump. Fill containing large numbers of Colonial ceramics appears to have been added after nearly sterile sediments filled the lowest six levels (Table 5-1).

\section{Pottery Kiln}

In an area about $8 \mathrm{~m}$ farther along the pipe trench, numerous broken bricks were found to be eroding from the west wall of the trench. The bricks were identical to those found in the mission, both as fragments in the gate midden and as structural elements in the restored portions of the mission buildings. It appeared that this might have been the location of a kiln of some sort. Since the location of the mission brick kiln had never been specified in the inventories, it was thought that this might be the remains of that structure. However, a few fragments of an unidentifiable type of ceramic were also present, suggesting that this may rather have been a pottery kiln.

The fill recovered when the kiln was excavated contained an interesting accumulation of artifacts (Table 5-2). As might be expected, the first level consisted of relatively recent artifacts including crown bottle caps, fragments of window glass, wire nails, and iron scrap. Levels 2, 3, and 4 contained a similar assortment of artifacts as those recovered from the

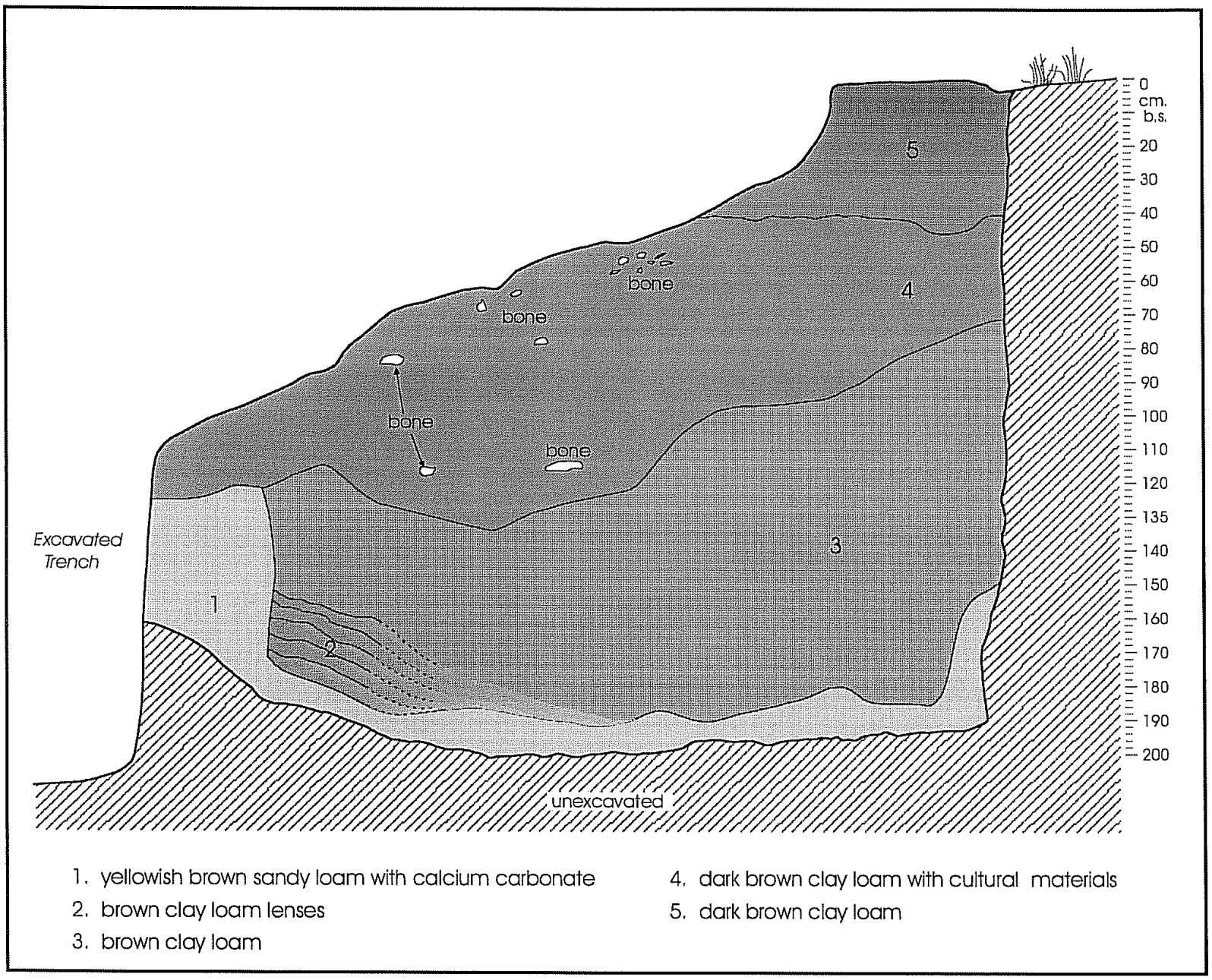

Figure 5-2. Profile of the south wall of BHT I, showing pit feature. 
Table 5-2. Artifacts Recovered from the Pottery Kiln (TUs 32, 33, 43, 46 \& 49) in Drainage System A

\begin{tabular}{|c|c|c|c|c|c|c|c|c|c|c|c|c|}
\hline $\begin{array}{c}\text { Approximate } \\
\text { Dates }\end{array}$ & Artifact Type & Lv. 1 & Lv. 2 & Lv. 3 & Lv. 4 & Lv. 5 & Lv. 6 & Lv. 7 & Lv. 8 & Lv. 9 & Baulk & Totals \\
\hline \multirow{7}{*}{ Colonial } & Goliad ware & 5 & 33 & 6 & 12 & & 1 & & & & & 57 \\
\hline & Other unglazed & & & 1 & 1 & & & 3 & & & & 5 \\
\hline & Majolicas & & 4 & 2 & & 1 & & 1 & & & & 8 \\
\hline & Lead-glazed & 6 & 10 & 10 & 4 & & & 2 & & & & 32 \\
\hline & Faience & & & & & & & 1 & & & & 1 \\
\hline & Trade beads \& jewelry & & & 1 & & & & & & & & 1 \\
\hline & Lithic artifacts & 3 & 11 & 14 & 3 & & & 2 & & 1 & & 34 \\
\hline \multirow{5}{*}{$\begin{array}{c}18 \text { th/ } \\
19 \text { th Century }\end{array}$} & Olive glass & & & 2 & 2 & & & & & & & 4 \\
\hline & Kiln-made ceramics & 33 & 1 & 18 & 3 & 15 & 34 & 153 & 602 & 26 & 67 & 952 \\
\hline & Musket balls & & & & 1 & & & & & & & 1 \\
\hline & Galera lead-glazed & & & 1 & & & & 3 & & & & 4 \\
\hline & Lamp chimney glass & 1 & 1 & 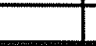 & & & & & & & & 2 \\
\hline \multirow{4}{*}{ 19th Century } & White earthenwares & 6 & 28 & 36 & 2 & 3 & & & & & & 75 \\
\hline & "Black" glass & & & 4 & & & & & & & & 4 \\
\hline & Cut nails & & 2 & & & & & & & & & 2 \\
\hline & Slate & & 1 & & & & & & & & & 1 \\
\hline \multirow{3}{*}{$\begin{array}{l}\text { Late } 19 \text { th/ } \\
\text { Early } 20 \text { th } \\
\text { Century }\end{array}$} & Decal printed whiteware & & 1 & & & & & & & & & 1 \\
\hline & \begin{tabular}{|l} 
Stonewares \\
\end{tabular} & 1 & 2 & & & & & & & & & 3 \\
\hline & Late Majolicas & & 2 & & & & & & & & & 2 \\
\hline \multirow{7}{*}{ 20th Century } & Clear glass (selenium) & 2 & 7 & 4 & & & & & & & & 13 \\
\hline & Bright green glass & 2 & & & & & & & & & & 2 \\
\hline & Machine made bottle & 1 & & 1 & & & & & & & & 2 \\
\hline & Painted glass & 1 & 1 & & & & & & & & & 2 \\
\hline & Wire nails & 1 & 13 & & & & & & & & & 14 \\
\hline & Coins & & 1 & & & & & & & & & 1 \\
\hline & Air gun pellets & 1 & & 1 & & & & & & & & 2 \\
\hline \multirow{11}{*}{ Not Datable } & Organics: Bone & 19 & 107 & 223 & 71 & 117 & 25 & 150 & 394 & 79 & 5 & 1,190 \\
\hline & Organics: Mussel shell & 1 & 1 & 1 & 2 & & & 2 & & & & 7 \\
\hline & Organics: Seeds & & & 1 & & & & & & & & 1 \\
\hline & Barn/Workshop & 3 & 6 & 4 & & & & & & & & 13 \\
\hline & Construction & 19 & 84 & 66 & 43 & 32 & 38 & 19 & 3 & 95 & & 399 \\
\hline & Kitchen/Household & 83 & 41 & 11 & 2 & & 3 & & 2 & & & 142 \\
\hline & Lithics (FCR) & 1 & 11 & 9 & 2 & 1 & 1 & & & & & 25 \\
\hline & Personal & & 2 & & & & & & & & & 2 \\
\hline & Metal scrap & 29 & 50 & 24 & 2 & & & 6 & 9 & & & 120 \\
\hline & Misc. & 22 & 13 & 53 & 62 & 21 & 49 & 24 & 167 & 61 & 11 & 483 \\
\hline & Totals & 240 & 433 & \begin{tabular}{l|l|}
493 \\
\end{tabular} & 212 & 190 & 151 & 366 & 1,177 & 262 & 83 & 3,607 \\
\hline
\end{tabular}

test units outside the west wall of the mission, including Goliad ware and other Colonial ceramics, a few sherds of whiteware, and numerous brick fragments. How this accumulation arrived at a point this far from the mission midden deposits is difficult to explain. The first few sherds of pottery that was later called "kiln pottery" also appeared in these levels. Levels 5 to 8 immediately changed to a deposit of kiln pottery sherds, animal bone (both burned and unburned), and numerous brick fragments, apparently the product of the waster pile that must have been used to fill the bottom section of the hole after the top of the kiln was removed (Table 5-2). The north and south walls bore traces of a thick plaster lining, apparently installed on the interior of the firebox, perhaps to protect the integrity of the brick walls (Figure 5-3). While some charcoal was present throughout the fill, it was particularly prevalent on the floor of the kiln (Figures 5-4 and 5-5).

On the floor of the kiln at the bottom of Level 8 were found half of a faience plate (Figure 5-6), part of a Valero water jar, and a section of a copper cooking vessel. They will be described in some detail in Chapter 6. 


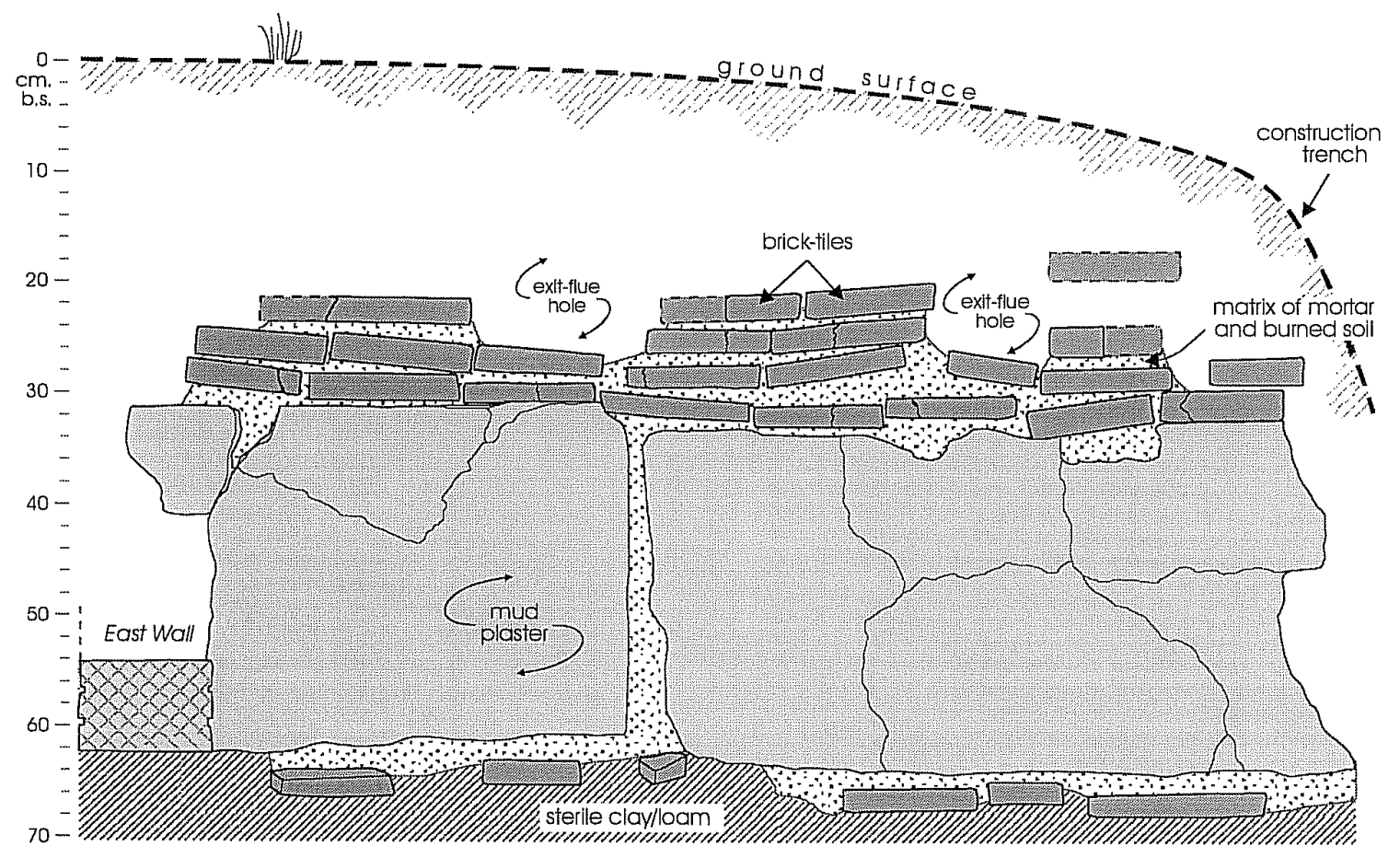

Figure 5-3. Profile of north wall of kiln, showing remains of flue holes and plastered brick interior of kiln.

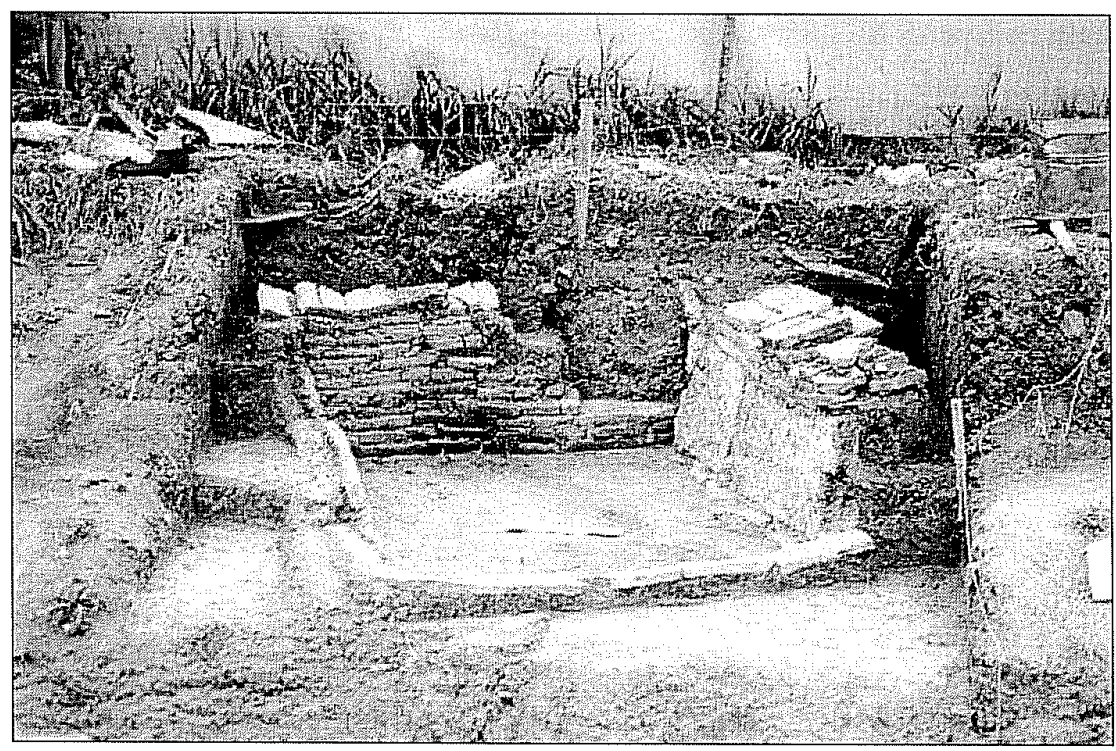

Figure 5-4. Photograph of kiln after excavation. 


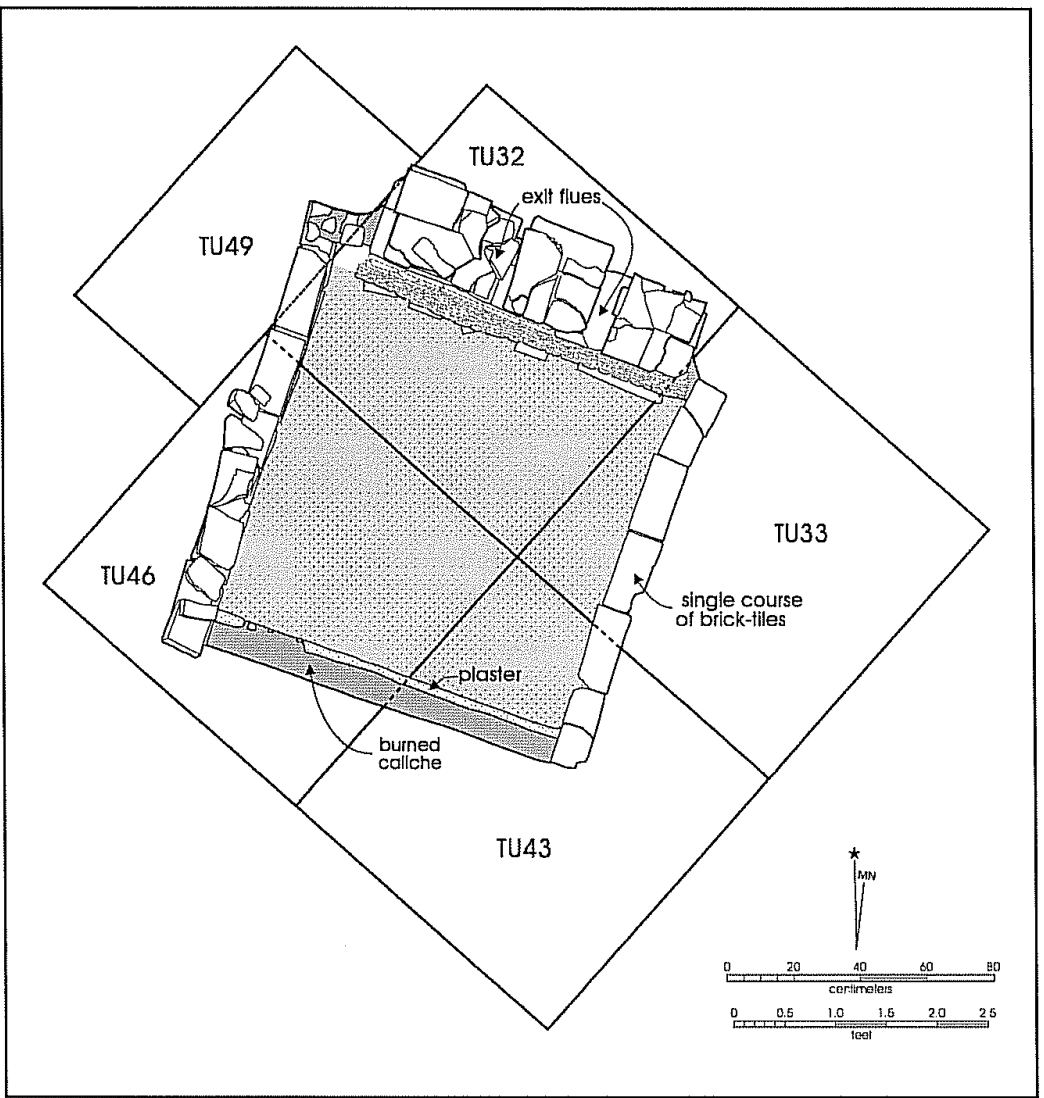

Figure 5-5. Plan view of the floor of the kiln.

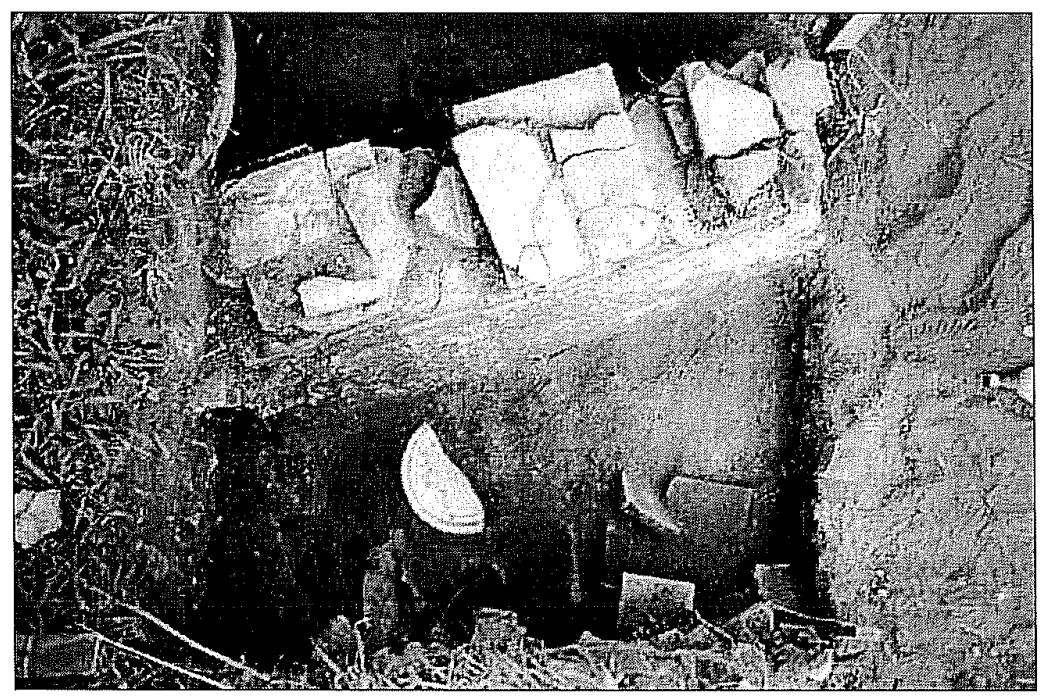

Figure 5-6. Faience plate fragment in the bottom of the kiln. 


\section{Monitoring Trench Excavation and Pipe Placement}

A portion of the MTP monitoring package required the monitoring of work to be conducted on Drainage System A. This work consisted of the installation of a 54-inch wastewater drainage pipe extending from Roosevelt Road, along Chavaneaux Road, down Espada Road, turning north near the northwest corner of Mission Espada, and terminating at the old channel of the San Antonio River.

After October 8, 1998, when CAR began monitoring, installation of the storm drain of Drainage System A progressed from west to east, with an archeologist monitoring the digging of the trench. Just north of Desague Road, Drainage A crossed underneath the reinforced concrete pipe carrying the Espada Acequia south under Espada Road (Figure 5-7).

At the point where the original trench (the portion dug without monitoring) had been reached, on the north side of Espada Road, a large junction box was to be installed, requiring the excavation of a trench approximately eight feet wide and 12 to 15 feet in depth. The profile revealed a road base of approximately 16 to 18 inches over a natural layer of black silty clay that transitioned into a dense level of yellow clay and gravel that was consistent to the depth of the excavation.

During the digging of the remaining sections of Drainage System A, no cultural deposits were observed. The only cultural deposits impacted by the trench for Drainage System A were those observed in the section dug before CAR monitoring began. Monitoring of Drainage System A construction continued until the end of January 1999 when it was agreed by all parties that it was no longer required.

\section{Drainage System B}

On September 30, 1998, two representatives from CAR and a representative from the City of San Antonio Office of Historic Preservation conducted a pedestrian survey of Drainage System B. This existing drainage ditch, located approximately mid way between Mission Espada and Aqueduct Park, extends from the east side of Espada Road to the new river channel (Figure 1-2). It had been cleared and was scheduled to be widened by an additional 20 feet. The survey revealed no indication of any cultural resources on the surface or in the cleared section of the old channel.

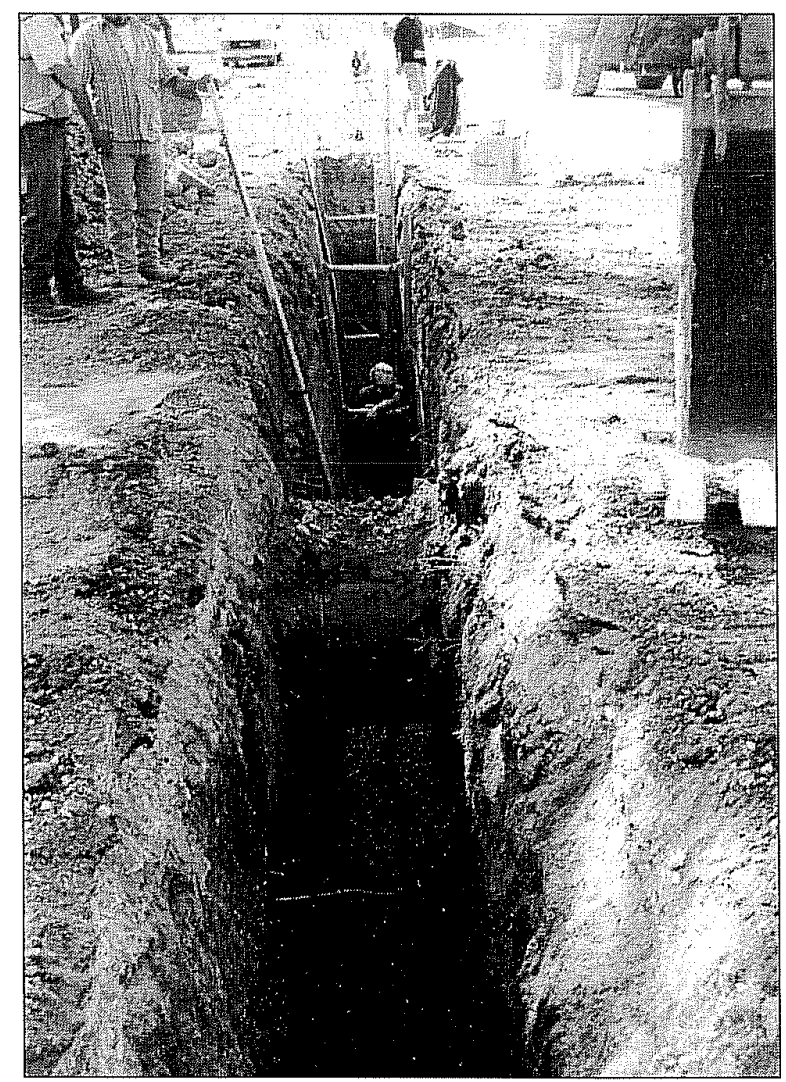

Figure 5-7. Photo showing trench for Drainage System A storm sewer passing under reinforced concrete pipe carrying the Espada Acequia.

In order in insure that no cultural resources would be destroyed by the widening of the ditch in Drainage System B, CAR dug a series of seven backhoe trenches between the path of the Espada Acequia and the Corps of Engineers outfall structure at the river channel (Figure 5-8). It was found that the seven equally spaced trenches provided adequate coverage of the area in question and the remaining three trenches committed to in the scope of work were not excavated. The trenches were cut to a depth of $2.5 \mathrm{~m}$, the effective depth of the machinery, on the south side of the right-of-way. All trenches revealed a shallow stratum of dark brown Frio clay loam (Fr), approximately $10-15 \mathrm{~cm}$ thick, over Lewisville series (LvB) black clay to the extent of the excavations (Taylor et al. 1991). Although there were minor differences in the soil composition between the eastern and western extremities, there were no signs of intrusion or cultural disturbance. No further archeological work was recommended for Drainage System B. 


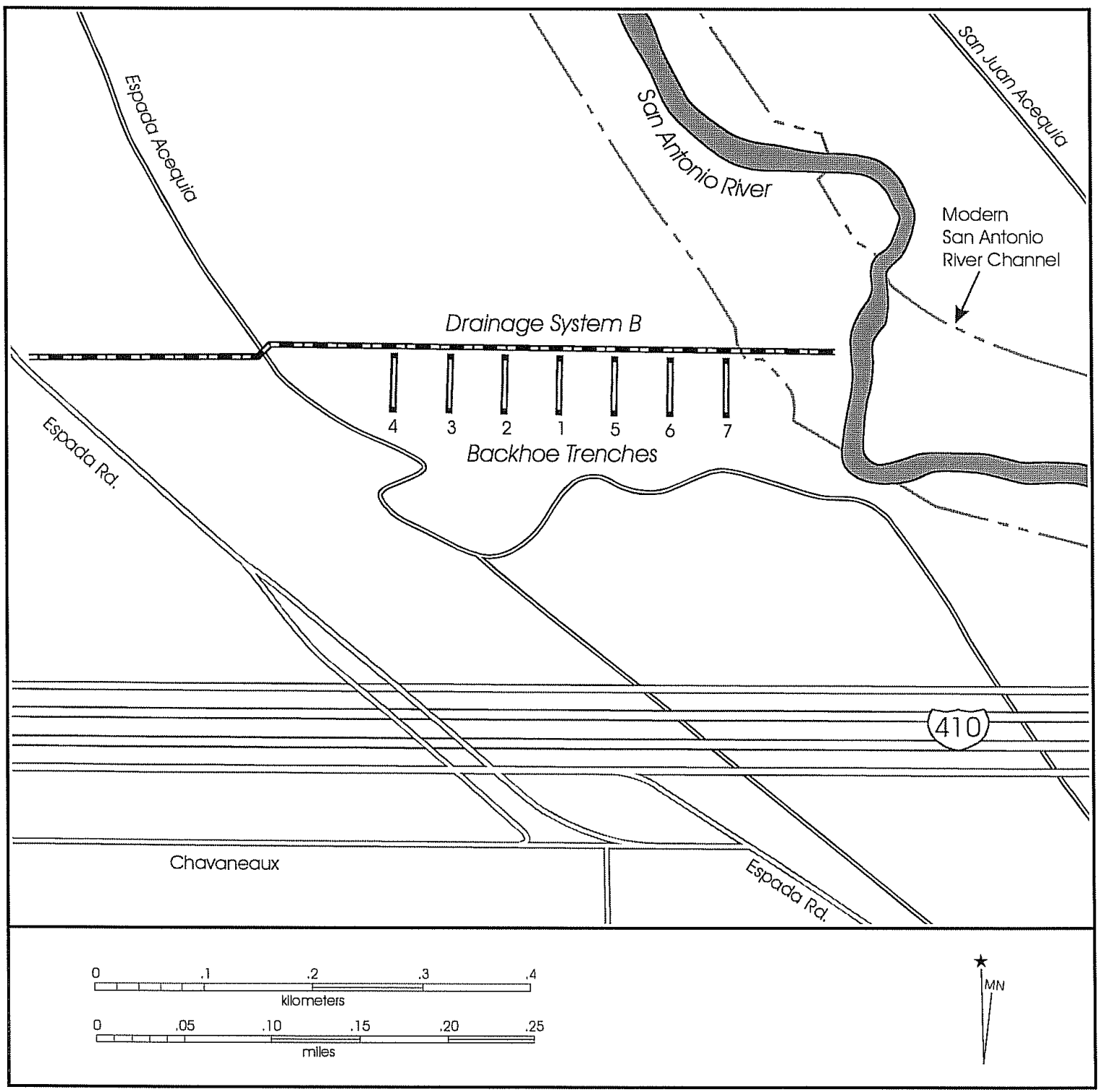

Figure 5-8. Map of Drainage System B, showing location of backhoe trenches. 


\section{Espada Acequia}

Planned construction also required the replacement of a water line and sewer force line from the southwest corner of the mission and north along Espada Road to near the intersection of $\mathrm{IH} 410$. This required the replacement of three crossings of the Espada Acequia system. Since the system was still operational, the construction had to be conducted in such a manner as to create a minimum of disruption to the flow of water.

At the time the contract was established between the City of San Antonio and the Center for Archaeological Research, a portion of the excavation had already begun. The initial cut for the wastewater line had begun between Espada Road and the river channel and the northernmost crossing had been completed. A portion of the 54-inch diameter reinforced concrete pipe lining had been installed across the northern branch of the Espada Acequia near the northwest corner of the mission compound, and the trench was open along the section near Espada Road.

At the time CAR monitoring began, October 8, 1998, excavation for the sewer force line had progressed to the first crossing of the acequia, the southernmost, at the intersection of Espada Road and Camino Coahuilteca near the southwest corner of the mission compound. The contractors began by removing the guardrail from the intersection and brought in 100 yards of clean fill to serve as a base for the road diversion around the acequia. They then removed the old steel culvert and replaced it with a 42inch concrete pipe set in an excavation $3 \mathrm{~m}$ below the original surface. Shortly after water began flowing in the acequia again, a problem became obvious. A mistake had been made in establishing the level of the flow line. The new flow line was below the grade level of the acequia and the flow was blocked. It was necessary for the conduit to be removed and replaced with three parallel 24-inch diameter pipes to raise the flow level to the proper height (Figure 5-9).

\section{Hike-and-Bike Trail}

The original field efforts were to consist of the placement of 15 50-x-50-cm test units along the proposed Hike-andBike Trail to determine the degree to which the unmonitored construction work had damaged the Colonial midden located outside the west wall of the mission (see Chapter 1), and to mitigate any further damage to this and any other features within the footprint of the trail. However, shortly after CAR staff began fieldwork along the Hike-and-Bike Trail,

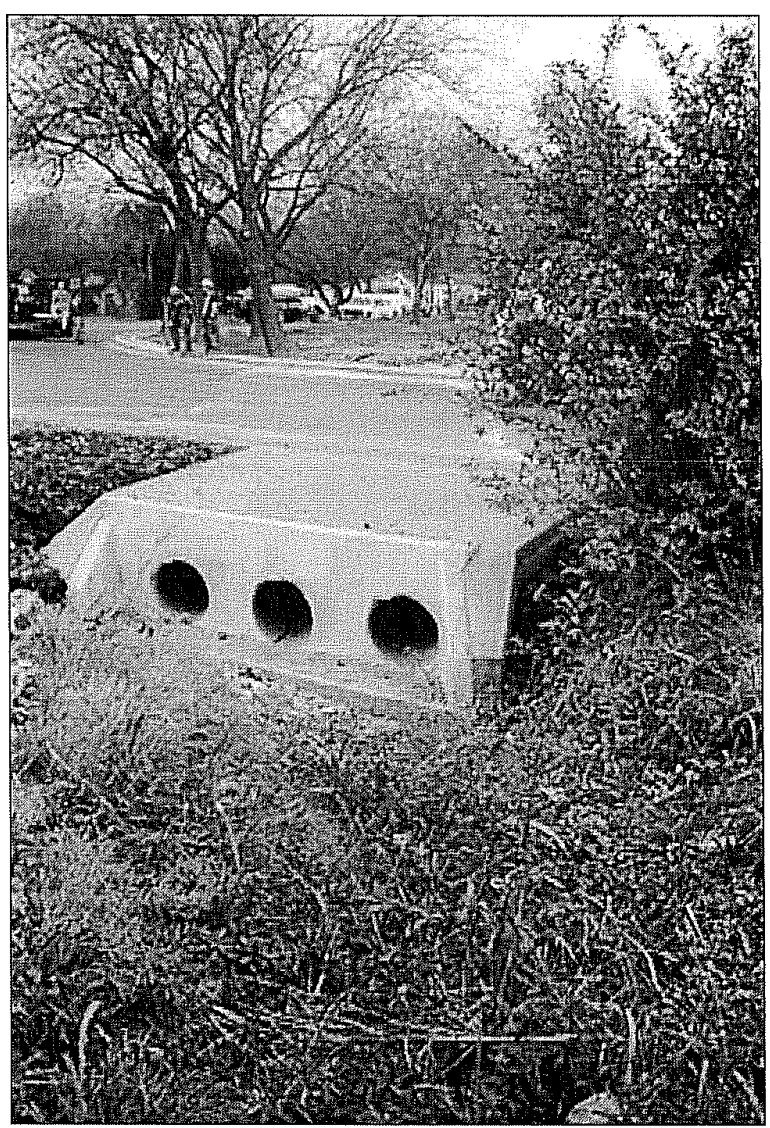

Figure 5-9. Completed crossing of Espada Acequia at Espada Road near the southwest corner of the mission.

construction workers graded the driveway from Espada Road into the parking lot inside the mission compound, north of the Chapel. This work was done while CAR staff were not present. The modern ground surface, including some badly deteriorated asphalt paving, was lowered approximately eight to twelve inches by this grading (see Figure 4-2), exposing part of what appeared to be a Colonial-period foundation near the southern edge of the opening in the mission wall known as the Northwest Gate.

As a result, additional test units were placed within the gateway as indicated in Figure 4-2. The following discussion of the results of the excavation of these units will begin with the units in the gateway and then continue north to the units along the Hike-and-Bike Trail. Artifacts located in each set of adjacent units are listed in tables, grouped by approximate dating. 


\section{Test Units in the Northwest Gateway}

When construction workers graded the driveway leading to the parking lot north of the Chapel, they uncovered part of a large limestone rock in the south side of the Northwest Gateway near the reconstructed wall. Sixteen units were excavated within the gateway to investigate a possible Colonial foundation. The units included 15 1-x-1-m units
(TUs 27-31, 36-40, 42, 44-45, 47 and 48) and one $0.30-\mathrm{x}$ 1-m unit (TU 41). A total of 5,142 artifacts was recovered from these units (Table 5-3). In addition, remains of a Colonial wall foundation and flagstone paving was uncovered. Figure 5-10 is a plan map of the Northwest Gateway units, showing the remains of the Colonial wall and flagstone paving.

Table 5-3. Artifacts from the Northwest Gateway Units (TUs 27-31, 36-42, 44-45, 47 \& 48)

\begin{tabular}{|c|c|c|c|c|c|c|c|c|}
\hline Approximate Dates & Artifact Type & Lv. 1 & Lv. 2 & Lv. 3 & Lv. 4 & Lv. 5 & Lv. 6 & Totals \\
\hline \multirow{7}{*}{ Colonial } & Goliad ware & 101 & 66 & 41 & 37 & 3 & & 248 \\
\hline & Other unglazed & 4 & 6 & & & & & 10 \\
\hline & Majolicas & 11 & 10 & 13 & 5 & 4 & & 43 \\
\hline & Lead-glazed & 17 & 6 & 2 & 1 & & & 26 \\
\hline & Trade beads \& jewelry & 9 & 4 & 5 & 6 & & & 24 \\
\hline & Lithic artifacts & 100 & 47 & 36 & 17 & 4 & & 204 \\
\hline & Chipped glass scrapper & 1 & & & & & & 1 \\
\hline \multirow{3}{*}{$\begin{array}{c}\text { 18th/ } \\
\text { 19th Century }\end{array}$} & Olive glass & 35 & 1 & 2 & & & & 38 \\
\hline & Chinese porcelain & 2 & 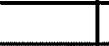 & & & & & 2 \\
\hline & Galera lead-glazed & 3 & 29 & & & & & 32 \\
\hline \multirow{4}{*}{ 19th Century } & White earthenwares & 36 & 5 & 6 & & & & 47 \\
\hline & Yellow wares & & 1 & & & & & 1 \\
\hline & "Black" glass & 3 & & & & & & 3 \\
\hline & Cut nails & 5 & 3 & & & & & 8 \\
\hline \multirow{7}{*}{$\begin{array}{l}\text { Late } 19 \text { th/ } \\
\text { Early } 20 \text { th }\end{array}$} & Stonewares & 2 & & 1 & & & & 3 \\
\hline & Clear glass (manganese) & 3 & & & & & & 3 \\
\hline & Milk bottles & 1 & 3 & & & & & 4 \\
\hline & Shell buttons & 1 & & & & & & 1 \\
\hline & Old electrical items & 1 & & & & & & 1 \\
\hline & .22 caliber short casing & & 1 & & & & & 1 \\
\hline & .38 caliber center fire & & & 1 & & & & 1 \\
\hline \multirow{3}{*}{ 20th Century } & Clear glass (selenium) & 4 & 1 & 2 & & & & 7 \\
\hline & Bright green glass & 1 & & & & & & 1 \\
\hline & Wire nails & 18 & 3 & 1 & & & & 22 \\
\hline \multirow{10}{*}{ Not Datable } & Organics: Bone & 900 & 1655 & 625 & 390 & 55 & 1 & 3,626 \\
\hline & Organics: Mussel shell & 7 & 6 & 5 & 2 & & & 20 \\
\hline & Activities & & 1 & & & & & 1 \\
\hline & Barn/Workshop & 17 & 35 & & & 1 & & 53 \\
\hline & Construction & 70 & 28 & 25 & 3 & & & 126 \\
\hline & Kitchen/Household & 104 & 141 & 7 & & & & 250 \\
\hline & Lithics (FCR) & 5 & 6 & 5 & 1 & & & 17 \\
\hline & Personal & 3 & 1 & 1 & & & & 5 \\
\hline & Metal scrap & 188 & 23 & 6 & 8 & 2 & & 227 \\
\hline & Misc. & 30 & 48 & 6 & & & & 84 \\
\hline & Totals & 1,682 & 2,130 & 790 & 470 & 69 & 1 & 5,142 \\
\hline
\end{tabular}




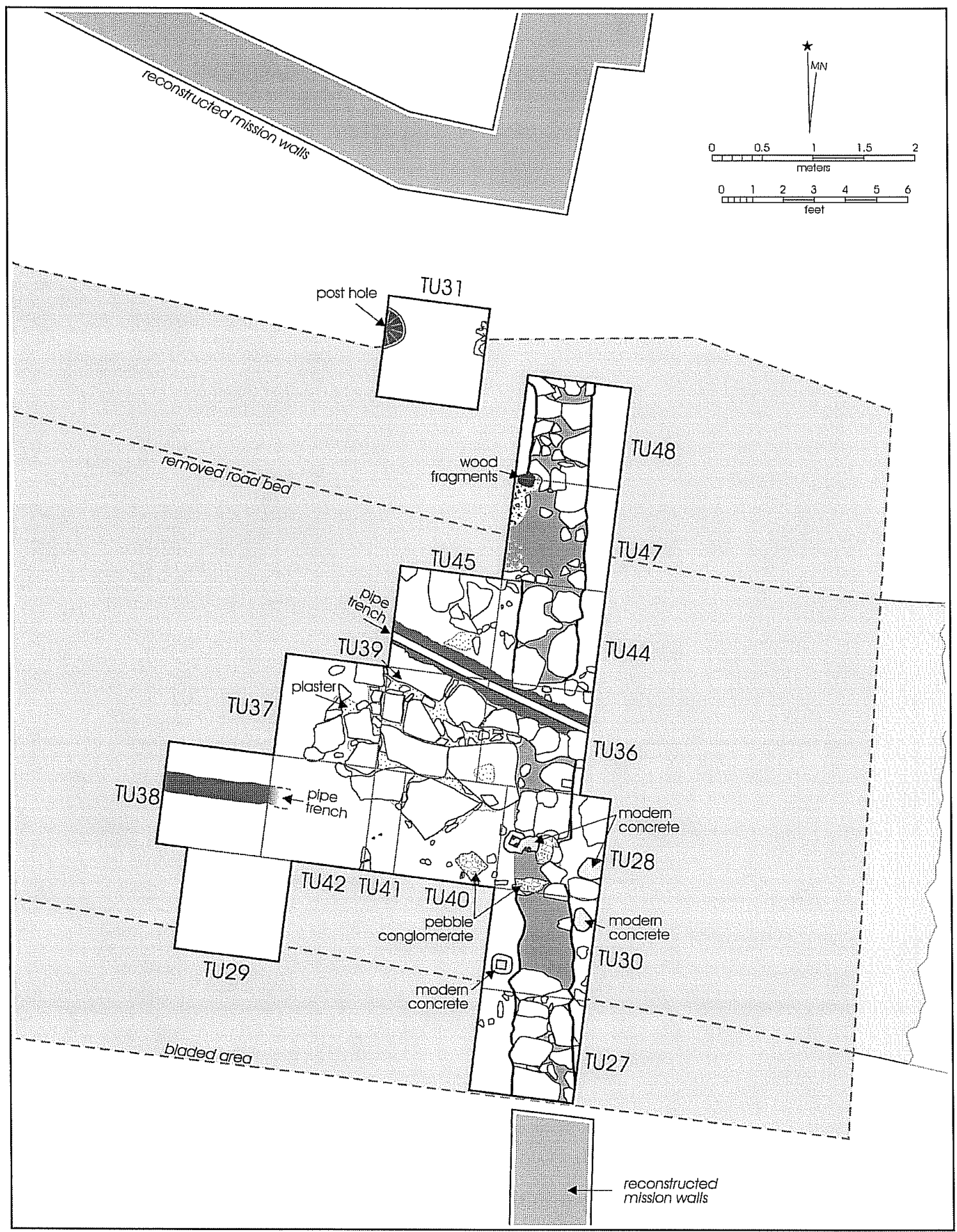

Figure 5-10. Plan map of Northwest Gateway units, showing Colonial wall foundation and flagstone floor west of the mission wall. 


\section{Colonial Foundation and Flagstone Paving}

The Colonial foundation was present in TUs 27, 28, 30, 36, 44, 47, and 48 (Figure 5-10). This foundation and the flagstone paving just west of it were designated Feature 7. The depth below surface in which the Colonial foundation was first encountered varied between units. It was typically found in the first $10-\mathrm{cm}$ level; however, because of the grading already mentioned, some parts of the foundation were not encountered until Level 3 $(20-30 \mathrm{~cm}$ below surface [cmbs]). In order to keep the parking lot north of the Chapel open, only half of the Northwest Gateway units were open at any time, with the other half covered by gravel (Figures 5-11 and 5-12).

Test Unit 27 was excavated through Level $6(0-57 \mathrm{cmbs})$ to determine the depth of the foundation. The remaining test units were excavated to a depth necessary to partially expose and identify the foundation. The excavation of TU 27 showed the foundation to be approximately $65 \mathrm{~cm}$ in width

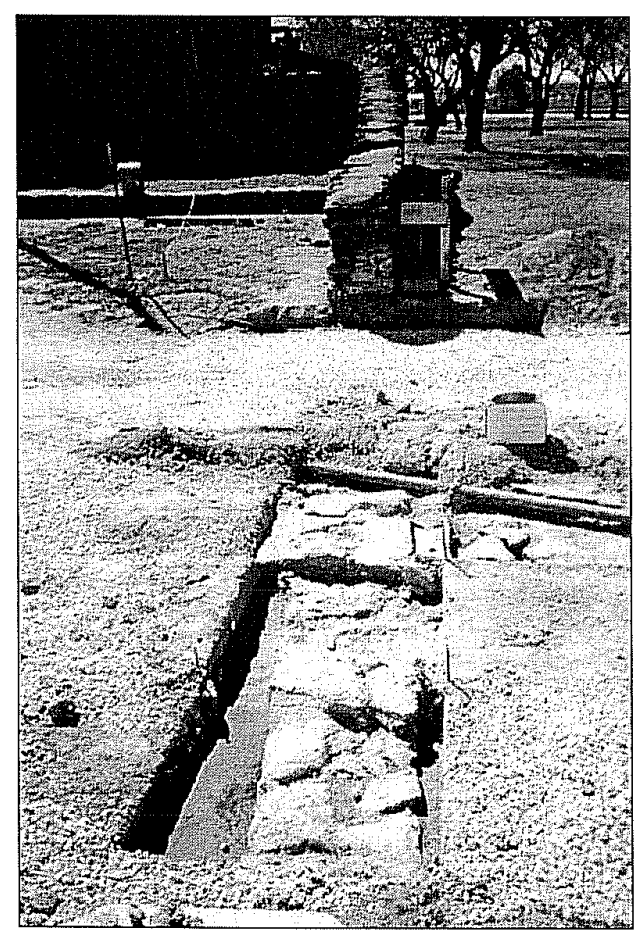

Figure 5-11. Colonial foundation in Northwest Gateway, TUS $48,47,44$, and 45 , looking south. Note gravel driveway at top of photo, covering the other gateway units. extending to a depth of $48 \mathrm{~cm}$ below the recently graded surface. In TU 27, the Colonial foundation was comprised of large limestone rocks and a soft, sandy, light gray (10YR $7 / 2$ ) mortar. The majority of the rock observed in the construction of the Colonial foundation was limestone; however, some of the rock encountered near the northern end of the foundation may have been sandstone. The Colonial foundation is offset from the existing reconstructed wall and angles slightly to the northwest (Figure 5-10). Later impacts to the foundation or adjacent to the foundation include concrete post settings in TUs 28 and 30; concrete and/or conglomerates present in TUs 28, 30, 36 and 47; removal or displacement of the upper course of foundation rock, presumably due to later construction activities and/or road construction in TUs 28,47 , and 48 ; a relatively recent cedar post at the juncture of TUs 47 and 48 ; and a two-inch water main crossing in TUs 45, 39, 44, and 36 (see Figures 5-10 through 5-13).

The flagstone paving was present in TUs $40,41,42,37,39$, and 45 (Figures 5-12 and 5-13). The paving was comprised of large tabular sandstone rock. In TUs 28 and 36, the sandstone was mortared directly to the Colonial foundation. The mortar appeared to be Colonial in age, consisting of a soft, sandy matrix. The flagstone paving was encountered in the first 10-cm level in TUs 39, 40,41,42, and 45; and in Levels 1 and 2 in TU $37(0-20 \mathrm{~cm}$ below the recently graded surface). The flagstone had been impacted by a two-inch water main in TUs 39 and 45 (the same pipe that impacts the Colonial foundation in TU 36). The flagstone paving did not appear to extend south of TUs 40,41 , and 42 nor west of TUs 37 and 42; however, it may extend north of TUs 37 and 45 .

\section{Test Unit Descriptions}

\section{Test Unit $27(1-x-1-m)$}

TU 27 was placed approximately $24 \mathrm{~cm}$ north of the reconstructed south wall that, together with the reconstructed north wall, forms the present Northwest Gateway into the mission compound (see Figure 4-2). The limestone foundation was uncovered in Level $1(0-7 \mathrm{cmbs})$ at $3 \mathrm{~cm}$ below the ground surface. The stone foundation, $65 \mathrm{~cm}$ in width, ran in a north/south direction and extended from 3 $\mathrm{cm}$ to $48 \mathrm{~cm}$ below ground surface. Beginning with Level 2 and continuing through Level 6 (7-57 cmbs), only that part of the unit west of the foundation was excavated due to the location of the Colonial foundation. The general soil stratigraphy was as follows: from 0 to $25 \mathrm{cmbs}$ the soil 


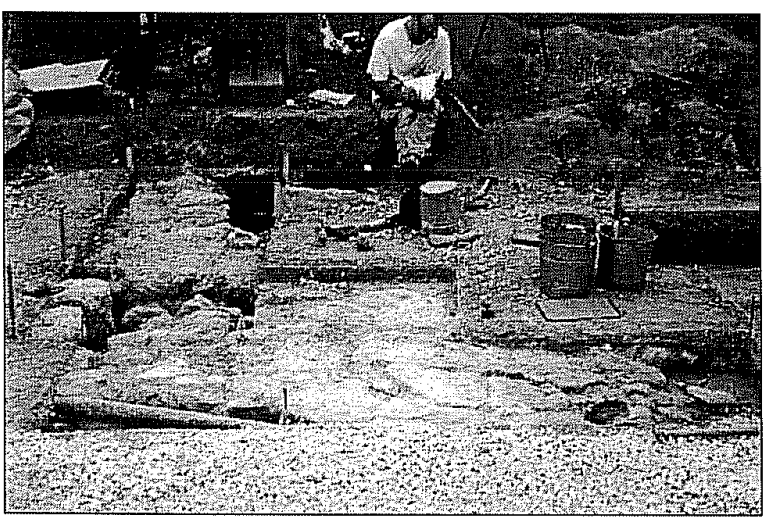

Figure 5-12. The southern Northwest Gateway units, looking south. Note gravel (in foreground) is now covering units seen in Figure 5-11.

consisted of a dark gray (10YR 4/1) loam; between 25 and $50 \mathrm{cmbs}$ the soil was a very dark grayish brown (10YR 3/2) loam; and from 50 to $57 \mathrm{cmbs}$ it was a dark grayish brown (10YR 4/2) loam. Artifacts recovered from Levels 1 and 2 $(0-17 \mathrm{cmbs})$ include glass fragments, one Tonalá Burnished ceramic sherd, bone, lithics, and construction material (sandstone and limestone fragments).

In Level 3 (17-27 cmbs) the soil in the northern one-third of the unit was slightly lighter and sandier than that observed in the southern part of the unit. By Level 5 (37-47 cmbs), a circular area was defined in the northern section of the unit and designated Feature 8 . Small amounts of charcoal were observed throughout Levels 5 and $6(37-57 \mathrm{cmbs})$. Artifacts recovered from Levels 4-6 (27-57 cmbs) include bone, shell, construction material, and one undecorated tin-glazed ceramic sherd.

In the northern one-third of TU 27, a difference in soil color and texture had been noted in Levels 3 and 4 (17-37 cmbs), and upon further excavation of Level $5(37-47 \mathrm{cmbs})$, the area appeared circular in shape. Designated Feature 8, the circular area was approximately $20 \mathrm{~cm}$ in diameter. The soil within Feature 8 consisted of a loose, very dark grayish brown (10YR 3/2) sandy clay loam. Inclusions within this soil included small fragments of mortar, and burned and unburned bone. A lighter colored area approximately $10 \mathrm{~cm}$ in width extended from the circular area east approximately $5 \mathrm{~cm}$ where it coincided with the Colonial foundation. By Level 6 (47-57 cmbs), Feature 8 was no longer present.

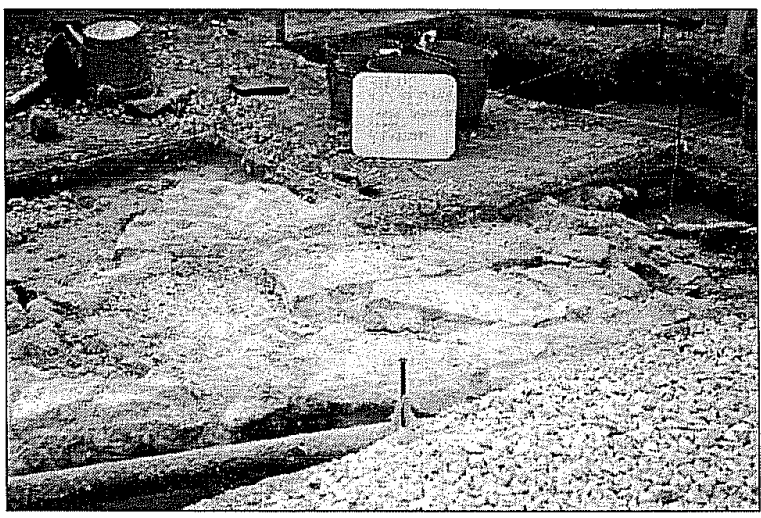

Figure 5-13. Flagstone paving in west of Colonial wall foundation.

\section{Test Unit $30(1-x-1-m)$}

TU 30 was located adjacent and north of TU 27. This unit was excavated to a depth of $10 \mathrm{~cm}$ below surface (Level 1) in order to expose the Colonial foundation. The soil was a sandy loam mixed with road gravel. A concrete post mold is located approximately $10 \mathrm{~cm}$ west of the foundation (Figure $5-10)$. The concrete post mold was $20 \times 20 \mathrm{~cm}$ in size and the square interior shows that the post was approximately $10 \times 10 \mathrm{~cm}$ in size. No wood fragments were present in this post mold. Another circular area of concrete was located in the northeast section of the unit, adjacent to the foundation. It was $20 \times 25 \mathrm{~cm}$ in size but showed no evidence of having contained a post. Artifacts recovered from Level 1 show a mix of eighteenth- to twentieth-century materials. Cultural material consists of Colonial and post-Colonial ceramic sherds, glass fragments, a cut nail, construction related materials (i.e., concrete, asphalt, mortar, brick/tile and sandstone fragments), lithics, wire, and iron scraps. Ceramics include Goliad ware, sandy paste lead glaze, Blue on White tin glaze, and whitewares (undecorated, transfer ware, handpainted, spatter, and cut sponge).

\section{Test Unit $28(1-x-1-m)$}

TU 28 was located adjacent and north of TU 30 . The Colonial foundation within TU 28 had been disturbed by the later additions of concrete post molds and possibly from road grading. One concrete post mold was located along the western edge of the foundation (Figure 5-10). It was similar in size and appearance to the one found in TU 30; 
$20 \times 20 \mathrm{~cm}$ in size with a square interior for a post approximately $10 \times 10 \mathrm{~cm}$ in size. Several fragments of wood were recovered from within the square hole. A larger circular area of concrete $30 \times 35 \mathrm{~cm}$ in size was located immediately east of the foundation (Figure 5-10). The concrete appeared to terminate at the bottom of Level 5 (47 cmbs). Two larger rocks, apparently part of the original foundation, were offset to the east. In the extreme southern part of TU 28, the disturbed Colonial foundation was not encountered until Level 3 (17-27 cmbs). A layer of small-stream worn pebbles and gravel (1-5 cm in diameter) mortared together rested upon the Colonial foundation in the southern part of TU 28 and the northern part of TU 30 .

The northern half of TU 28 was excavated from Level 1 through Level $3(0-27 \mathrm{cmbs})$. The southern half of TU 28 was excavated from Level 1 through Level 5 (0-47 cmbs). The soil on the east and west sides of the foundation varied considerably (Figure 5-14). The soil on the west side of the foundation showed considerable disturbance. From 0-14 cmbs, a gray (10YR 6/2) loam containing sandstone and limestone fragments, charcoal, and wood fragments was present. Artifacts recovered from Levels 1 and 2 (0-17 cmbs) include Colonial and post-Colonial ceramics, glass fragments, bone, window glass, cedar post fragments, fragments of concrete with wood impressions, sandstone fragments, wire fragments, iron scrap fragments and miscellaneous rock. Ceramics include Goliad ware, Tonalá, lead-glazed ware, tin-glazed and an undecorated whiteware sherds. Between 14 and $30 \mathrm{cmbs}$, the soil was a grayish brown (10YR 5/2) loam containing an abundance of limestone pebbles, wood fragments, and small amounts of charcoal. Artifacts recovered from Level 3 (17-27 cmbs) include bone, brick/tile fragments, mortar, and cedar post fragments. From 30-47 cmbs, a dark gray (10YR 4/1) loam was present. Artifacts from Levels 4 and 5 (27-47 cmbs) consist of bone, brick/tile fragments, lithics, and wire.

On the east side of the foundation the soil was a gray (10YR $5 / 1$ ) loam from $0-47 \mathrm{cmbs}$ with the upper $18 \mathrm{~cm}$ more compact and containing a few limestone pebbles (Figure 5-14). The Colonial foundation within TU 28 extended deeper than 47 cmbs.

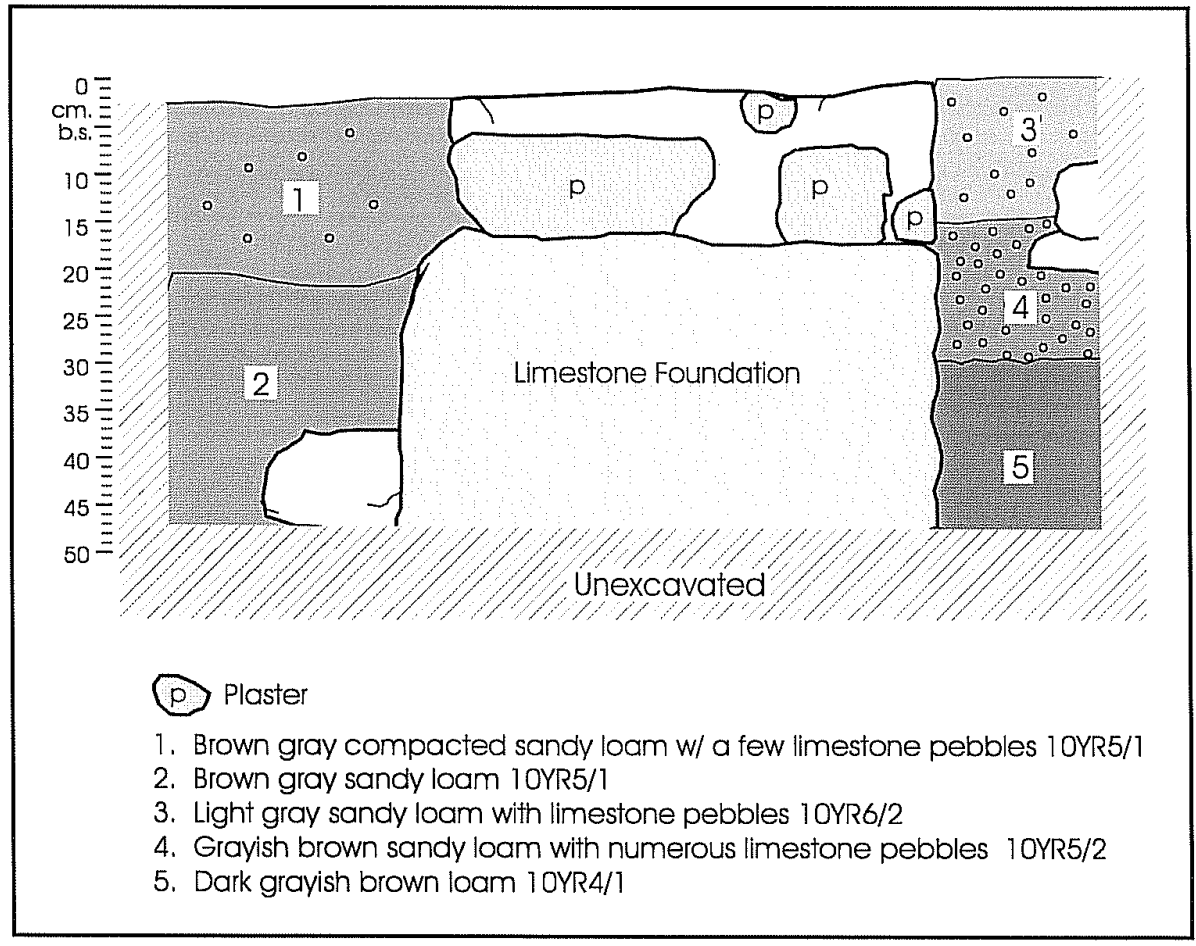

Figure 5-14. Profile of the south wall of TU 28, showing limestone wall foundation. 


\section{Test Unit $36(1-x-1-m)$}

TU 36 was located adjacent and north/northwest of TU 28 (Figure 5-10). This unit was offset $30 \mathrm{~cm}$ west of TUs 27, 30 , and 28 due to the angle of the Colonial foundation. In TU 36, a two-inch water main cut through the Colonial foundation and the flagstone paving in the northern part of the unit (Figure 5-12). TU 36 was dug only to a depth of 5 $\mathrm{cmbs}$ in order to expose the foundation. In addition to the presence of the Colonial foundation, three flat flagstones extended from the edge of the foundation to the west. The flagstones were mortared to the foundation using Colonial mortar. The soil from Level $1(0-5 \mathrm{cmbs})$ was comprised of a gray (10YR 5/1) loam mixed with gravels, however, at the base of the level, mottled clay with small traces of charcoal was present. Concrete was observed near the east wall of the unit and around a small portion of the pipe. Artifacts recovered from Level 1 include Goliad ware sherds, glass fragments, bone, wire nails, mortar, construction materials (concrete, asphalt, sandstone), lithics, and metal scrap.

\section{Test Unit $44(1-x-1-m)$}

TU 44 was located adjacent and north of TU 36 (Figure $5-10)$. TU 44 was excavated through Level $1(0-7 \mathrm{cmbs})$ in order to expose the Colonial foundation. The foundation was encountered between 1 and $2 \mathrm{cmbs}$. The soil from Level 1 consisted of a gray (10YR 5/1) loam. Artifacts recovered from Level 1 ( $0-7 \mathrm{cmbs})$ include Colonial ceramics, bone, wire nails, and metal scrap.

\section{Test Unit $47(1-x-1-m)$}

TU 47 was located adjacent and north of TU 44 (Figure 5-10). TU 47 was excavated through Level 2 (0-20 cmbs) in order to expose the foundation. Foundation rocks were encountered between 5 and $6 \mathrm{cmbs}$ in the extreme northern part of the unit and at approximately $13 \mathrm{cmbs}$, smaller rocks were present throughout the remainder of the unit. The upper course of rock observed in TUs $27,28,30,36$, and 44 appears to have been removed or displaced from the Colonial foundation in TU 47. The rocks encountered in Level 2 (10$20 \mathrm{cmbs}$ ) of TU 47 were also smaller compared to the larger foundation rocks observed in the units discussed above. In Level $1(0-10 \mathrm{cmbs})$, a recent cedar post was present in the northwest corner of TU 47. A caliche matrix containing stream-worn pebbles and gravels (1-4 cm in size) was observed in the northwest and central part of the unit in Level $2(10-20 \mathrm{cmbs})$. Two wire nails and two cut nails were recovered from beneath the caliche matrix, indicating a twentieth century date for this layer. In addition, two relatively large conglomerates (approximately $50 \times 20 \mathrm{~cm}$ in size) were present along the western edge of the unit. The northernmost conglomerate, located near the cedar post, was comprised of limestone and stream rolled gravels (larger gravels than those observed in the caliche matrix) and the southernmost conglomerate appeared to consist of a dark clay loam mixed with mortar. Artifacts recovered from Level 1 (0-10 cmbs) include Colonial and post-Colonial ceramic sherds, glass fragments, bone, brick/tile fragments, iron scrap, and cedar post fragments. Artifacts recovered from Level 2 (10-20 cmbs) represent eighteenth- through twentieth-century materials including Colonial sherd and one post-Colonial ceramic sherd, glass fragments, cut and wire nails, mortar fragments, lithics, and metal scrap.

\section{Test Unit $48(I-x-l-m)$}

TU 48 was located adjacent and north of TU 47 (Figure $5-10)$. This unit was excavated through Level $2(0-20 \mathrm{cmbs})$ in order to isolate the Colonial foundation. With the exception of the extreme southern area of TU 48 where the foundation rock was found at approximately 5 to $6 \mathrm{cmbs}$ (this higher point of foundation rock is a continuation of that observed in the extreme northern part of TU 47), the Colonial foundation was not encountered until the bottom of Level $1(0-10 \mathrm{cmbs})$. This area of the foundation, as in TU 47, appeared to be disturbed and the upper course of rock had been removed or displaced. The upper $5 \mathrm{~cm}$ of Level 1 (0-5 cmbs) was comprised of recent road gravels. At $5 \mathrm{cmbs}$, a thin lens of asphalt was present. The bottom 5 $\mathrm{cm}$ of Level $1(5-10 \mathrm{cmbs})$ consisted of a compact brown (10YR 5/3) sandy loam mixed with pea-size gravels. A lens of white caliche matrix was also noted in the west wall profile. Artifacts recovered from Level 1 represent eighteenth- through twentieth-century materials including Colonial and post-Colonial ceramic sherds, bone, asphalt, lithics, miscellaneous rock, and one wire nail. Level 2 (10$20 \mathrm{cmbs}$ ) consisted of an extremely compact, very dark grayish brown (10YR 3/2) clay loam on both the east and west sides of the Colonial foundation. Artifacts collected from Level 2 were bone and one sandstone fragment.

\section{Test Unit $40(1-x-1-m)$}

TU 40 was located adjacent and west of TU 28 (Figure 5-10). This unit was excavated through Level $1(0-7 \mathrm{cmbs})$. The soil in Level 1 consisted of a packed clay loam with limestone and sandstone pebbles and cobbles. Flagstones were present in the northern half of the unit and a solid conglomerate of small river gravel $(1-5 \mathrm{~cm}$ in diameter), approximately $20 \times 20 \mathrm{~cm}$ in size, was located in the 
southeastern corner of TU 40 (Figure 5-10). Numerous fragments of iron scrap were recovered from Level 1 and the majority of this metal was found in the southeastern quadrant. Artifacts recovered from Level $1(0-7 \mathrm{cmbs})$ show a mix of eighteenth- to twentieth-century materials including Colonial and post-Colonial ceramic sherds, bone, window glass, a cut nail, lithics, copper and iron scrap, and plastic.

\section{Test Unit 39 (I-x-I-m)}

TU 39 was located adjacent and west of TU 36 (Figure $5-10)$. This unit was excavated through Level $1(0-7 \mathrm{cmbs})$. The soil in Level 1 was comprised of a compact clay loam with small limestone pebbles. Large flagstone slabs with Colonial mortar were present across the unit (Figure 5-13) and a two-inch water main was located in the extreme northeastern part of TU 39 (Figure 5-10). Artifacts collected from Level $1(0-7 \mathrm{cmbs})$ show a disturbed deposit of cultural material including glass fragments, bone, shell, lithics, and a piece of plastic.

\section{Test Unit 45 (1-x-I-m)}

TU 45 was located adjacent and west of TU 44 (Figure $5-10)$. This unit was excavated through Level $1(0-10 \mathrm{cmbs})$. The soil was comprised of a compact clay loam. Three large flagstone (sandstone) slabs and a few small sandstone rocks were present, primarily in the northern and eastern halves of the unit. A large sandstone slab was also located in the southwest quadrant of the unit and extended southward into TU 39. The flagstone in TU 45 appeared disturbed and was not mortared to the Colonial foundation as the flagstone paving was in TUs 36 and 39. In addition, a two-inch water main (also present in TUs 36 and 39) crossed the southern part of the unit running in a northwest-southeast direction (Figure 5-13). Cultural material shows a mix of eighteenththrough twentieth-century artifacts including Colonial ceramics, wire nails, three glass trade beads, and iron scrap.

\section{Test Unit $37(1-x-1-m)$}

TU 37 was located adjacent and west of TU 39 (Figure $5-10)$. This unit was excavated through Level $2(0-20 \mathrm{cmbs})$. Level 1 (0-10 cmbs) contained a brown sandy loam soil from approximately $0-6 \mathrm{cmbs}$. A layer of caliche (possibly road base) of varied thickness was present across the unit extending from roughly $6-8 \mathrm{cmbs}$ in the eastern half of the unit and from $6-10 \mathrm{~cm}$ in the western half. A thin layer of pea gravel was also present directly beneath the caliche, primarily in the western part of the unit. Flagstone comprised of large sandstone slabs first appeared in the southeast quadrant of TU 37 in Level 1. The flagstone extended into Level 2 expanding to occupy the entire eastern half of the unit and the extreme southern edge of TU 37 (Figure 5-10). Artifacts recovered from Level $1(0-10 \mathrm{cmbs})$ show a mix of eighteenth- through nineteenth-century materials including Colonial and post-Colonial ceramic sherds, glass fragments, bone, shell, a cut nail, asphalt, lithics (including one unifacal expedient scraper), and the back portion of a compound button.

\section{Test Unit 41 (1-x-0.30-m)}

TU 41 was located adjacent and west of TU 40 . It was sized to coincide with the offset of TUs $36,44,47$, and 48 in order that the west wall of this unit would line up with the west walls of TUs 39 and 45 (Figure 5-10). This unit was excavated through Level $1(0-7 \mathrm{cmbs})$. The soil was a clay loam containing limestone and sandstone pebbles. A large flagstone was present in the northern part of TU 41. Colonial mortar appeared to be present on the southeastern edge of this rock as well as between two sandstone cobbles located in the southwestern corner of the unit. Artifacts recovered from Level 1 are comprised of a mix of eighteenth- to twentieth-century materials including a Goliad ware ceramic sherd, glass fragments, bone, asphalt, cut nails, electrical wire, iron scrap, and lithics.

\section{Test Unit $42(1-x-1-m)$}

TU 42 was located adjacent and west of TU 41 (Figure $5-10)$. This unit was excavated through Level 2 (0-20 cmbs). Levels $1(0-10 \mathrm{cmbs})$ and $2(10-20 \mathrm{cmbs})$ were comprised of a clay loam. Stream-worn gravel (approximately $5 \mathrm{~cm}$ in diameter) was present in the southeast corner of the unit within Level 1. This rock was similar to that observed in TU 40 (southeast corner) but it was more dispersed and not concentrated in one locale. In Level 2 (10-20 cmbs), the flagstone (sandstone) encountered in TU 41 extended into TU 42 and was present in the northeast corner of TU 42 (Figure 5-10). With the exception of the northeast corner of this unit, TU 42 was devoid of the flagstone paving. Cultural material recovered from Levels 1 and 2 show a mix of eighteenth- to twentieth-century artifacts indicating disturbance of these levels. Artifacts include Colonial sherds and one post-Colonial ceramic sherd, glass fragments, bone, a leather shoe heel, lithics (including the proximal end of a Guerrero point), one glass trade bead, barbed wire and plastic. 


\section{Test Unit $38(1-x-1-m)$}

TU 38 was located adjacent and west of TU 42 (Figure 5-10). This unit was excavated through Level 3 (0-30 cmbs). A grayish brown (10YR 2/5) clay loam containing some river gravel extended from the ground surface to approximately $16 \mathrm{cmbs}$. In parts of the northeast and southeast quadrants of the unit, traces of a thin caliche-like lens was present. In the southeast corner of TU 38, charcoal and bone fragments were also observed. From approximately 16 to $20 \mathrm{cmbs}$, the soil consisted of a very dark grayish brown (10YR 2/3) clay loam. A setting trench for a pipe running in an east/west direction through the northern part of the unit was encountered at approximately $16 \mathrm{cmbs}$ (Figure 5-10). The setting trench was excavated to the base of the trench ( $23 \mathrm{cmbs}$ ). The soil within the trench was composed of a light gray soil, extremely loose in texture. The pipe was no longer present in TU 38. Due to the installation of this pipe, Levels 1 and 2 showed considerable disturbance. Artifacts recovered include Colonial and post-Colonial ceramic sherds, bone, glass fragments (including milk bottle fragments), wire nails, lithics, three beads, and a latenineteenth- or early-twentieth-century shell button. Since artifacts recovered from Level 3 (20-23 cmbs) came only from within the setting trench, artifact recovery was low. Cultural materials from Level 3 consist of one Goliad ware ceramic sherd, bone, shell, brick/tile fragments, and iron scrap. It is not known whether the flagstone paving previously extended into TUs 42 and 38 and the installation of the pipe resulted in its removal or whether the paving was never present in this area.

\section{Test Unit 29 (1-x-1-m)}

TU 29 was located adjacent and south of TUs 38 and 42 (Figure 5-10). This unit was excavated through Level 4 (0$40 \mathrm{cmbs})$. During the excavation of Level $1(0-10 \mathrm{cmbs})$, a brown (10YR 5/3) sandier soil containing a few limestone pebbles was encountered in the western part of the unit extending from approximately 3 to $8 \mathrm{cmbs}$. Directly beneath this brown soil, a band of light gray (10YR 7/2) sand $2 \mathrm{~cm}$ thick $(8-10 \mathrm{cmbs}$ ) extended across the unit. From roughly 10 to $18 \mathrm{cmbs}$, the soil consisted of a light brownish gray (10YR 6/2) sandy clay loam containing limestone pebbles and cobbles and a few pieces of charcoal. This stratum was thinner in the western part of the unit and became thicker in the eastern part. From $18-40 \mathrm{cmbs}$, the soil was comprised of a dark grayish brown (10YR 4/2) clay loam. Artifacts recovered from Level $1(0-10 \mathrm{cmbs})$ represent a mix of eighteenth- to twentieth-century material including Colonial and post-Colonial ceramic sherds, glass fragments, lithics (including one complete Guerrero arrow point), two glass trade beads, and wire. Levels $2(10-20 \mathrm{cmbs})$ and $3(20-30$ $\mathrm{cmbs}$ ) contained only Colonial-age artifacts. These include Goliad ware and tin-glazed ceramic sherds, bone, shell, lithics and two dark Bluebird Blue glass trade beads. No artifacts were recovered from Level 4.

\section{Test Unit 31 (1-x-I-m)}

TU 31 was the northernmost unit within the Northwest Gateway (Figure 5-10). This unit was excavated through Level $5(0-50 \mathrm{cmbs})$. As stated previously, the driveway in the Northwest Gateway had been recently cut and graded resulting in the removal of approximately $30 \mathrm{~cm}$ of soil. TU 31 was placed so that the northern half of the unit was located upon the uncut or original ground surface and the southern half was placed within the recent cut. Levels 1 and $2(0-20$ cmbs) occurred only in the northern half of the unit. At 26 cmbs, the recently cut surface (southern half of the unit) was encountered. Therefore, Level 3 was comprised of the northern half of the unit from $20-30 \mathrm{cmbs}$ and the southern half of the unit from $26-30 \mathrm{cmbs}$. Levels $4(30-40 \mathrm{cmbs})$ and 5 (40-50 cmbs) included the entire unit (both northern and southern halves).

From $0-10 \mathrm{cmbs}$, the soil was comprised of a gray (10YR 6/1) loam containing numerous roots. A layer of asphalt approximately $2 \mathrm{~cm}$ thick extended from $10-12 \mathrm{cmbs}$. The asphalt layer was at a slightly lower elevation in the north wall profile (12-14 cmbs). From 12-22 cmbs, the soil was comprised of a light brownish gray (10YR 6/2) loam containing stream rolled gravel $1-4 \mathrm{~cm}$ in diameter. Also present within this soil were a few sandstone rocks and pieces of asphalt. From $22-38 \mathrm{cmbs}$, the soil was comprised of a gray (10YR 6/1) loam with some charcoal and bone fragments. This soil was largely present within Levels 3 and $4(20-40 \mathrm{cmbs})$. Within this gray loam, a layer of pea gravel ( 0.5 to $2 \mathrm{~cm}$ in diameter) was present from approximately 27-34 cmbs. In addition, a charcoal ring about $40 \mathrm{~cm}$ in diameter, designated Feature 9, was encountered in the western part of the unit at $26 \mathrm{cmbs}$. Artifacts recovered from Levels 1-3 $(0-30 \mathrm{cmbs})$ show a mix of eighteenth- through twentieth-century cultural material including Colonial and post-Colonial ceramic sherds, glass fragments, wire nails, lithics, two small dark Bluebird Blue glass trading beads and two square jet rosary beads, bone, and asphalt. Artifacts recovered from Level 4 (30-40 cmbs) represent Colonial 
Table 5-4. Artifacts Recovered from TU 2

\begin{tabular}{|c|c|c|c|c|c|c|c|}
\hline Approximate Dates & Artifact Type & Lv. 1 & Lv. 2 & Lv. 3 & Lv. 4 & Lv. 5 & Totals \\
\hline \multirow{6}{*}{ Colonial } & Goliad ware & & 7 & 18 & 14 & 1 & 40 \\
\hline & Other unglazed & & 3 & 1 & 5 & & 9 \\
\hline & Majolicas & & . & 5 & 5 & 1 & 11 \\
\hline & Lead-glazed & & 1 & 7 & 2 & 1 & 11 \\
\hline & Piloncillo molds & & 1 & & & & 1 \\
\hline & Lithic artifacts & 1 & 3 & 4 & 1 & & 9 \\
\hline \multirow{2}{*}{ 18th/19th Century } & Galera lead-glazed & & 2 & 4 & 3 & & 9 \\
\hline & Lamp chimney glass & & & 2 & & & 2 \\
\hline 19th Century & White earthenwares & & & & 1 & & 1 \\
\hline \multirow{5}{*}{ Not Datable } & Organics: Bone & & 91 & 145 & 92 & 16 & 344 \\
\hline & Organics: Mussel shell & & 1 & & 3 & & 4 \\
\hline & Construction & & 1 & & 3 & 2 & 6 \\
\hline & Lithics (FCR) & & 2 & & & & 2 \\
\hline & Metal scrap & & & 1 & & & 1 \\
\hline & Totals & 1 & 112 & 187 & 129 & 21 & 450 \\
\hline
\end{tabular}

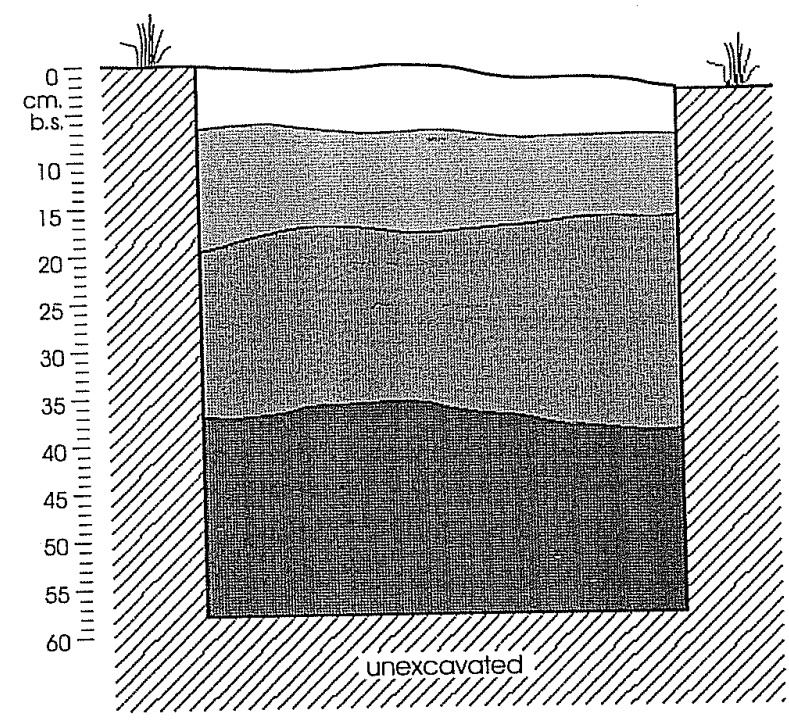

modern road gravel

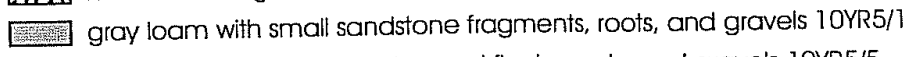

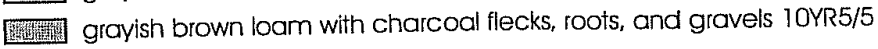

Fery dark grayish brown clay loam 10YR3/2

Figure 5-15. Profile of east wall of TU 2. 
age material. These artifacts include Goliad ware, sandy paste lead-glazed and tin-glazed ceramic sherds, bone, lithics, a brick/tile fragment, and iron scrap. From 38-50 cmbs, the soil was a very dark grayish brown (10YR 3/2) clay loam. Level 5 (40-50 cmbs) was comprised of this soil. Fewer artifacts were recovered from this level; however, they all appear to be associated with the Colonial period. They include Goliad ware and tin-glazed ceramic sherds, bone, lithics, and iron scrap. TU 31 was terminated at the base of Level 5 (50 cmbs).

Feature 9, the burned post, was comprised of a relatively large $(40 \mathrm{~cm}$ in diameter) semi-circular charcoal post located in the west wall of TU 31. It was bordered by a thin ring approximately $3 \mathrm{~cm}$ in thickness of burned soil/ clay. The post extended from $27-37 \mathrm{~cm}$ below the uncut ground surface (northern half of TU 31). A layer of small pea gravel (.5 to $2 \mathrm{~cm}$ in diameter) abutted the southern edge of the feature and extended across the southern part of TU 31 from $30-35 \mathrm{cmbs}$. This same pea gravel layer was present at the same depth in the west wall profile adjacent and north of the post and in the north wall profile. It is unknown whether Feature 9 is associated with the Colonial or post-Colonial period.

\section{Test Units along the Hike-and-Bike Trail}

TUs 1-14 were initially set up to test the Hike-and-Bike Trail. Most were placed within the area already bladed, but TUs $1,5,7,9,11$, and 13 were outside the bladed area (see Figure 4-2). TUs 15-26 were placed with regards to what was found in the first 14 units. TUs $17,22,23$, and 25 were located outside the bladed area. TUs 21,24 , and 26 were partially in the bladed area.

The test units are detailed below. They will be considered from the south, working north. Adjacent units will be considered together. Artifact tables with each unit or group of units are divided by level, and artifacts are grouped into one of the six dating categories described at the beginning of this chapter.

\section{Test Unit $2(50-x-50-\mathrm{cm})$}

TU 2 was one of the $14(50-x-50-\mathrm{cm})$ units set up to initially test the project area for intact Colonial deposits. TU 2 was located adjacent to the Northwest Gateway (see Figure 4-2). Level 1 (0-8 cmbs) consisted almost entirely of gravel and only a single lithic artifact was recovered from this level (Table 5-4). Between 6 and $18 \mathrm{cmbs}$, the soil was a gray
(10YR 5/1) loam containing small sandstone fragments, roots, and some gravel (Figure 5-15). The cultural material recovered from Level 2 is Colonial in age and includes ceramics, bone, shell, and lithics (Table 5-4). From 18-35 cmbs, the soil was a grayish brown (10YR 5/2) loam with charcoal flecks, roots, and small rocks and pebbles. This soil was largely present in Levels $3(18-28 \mathrm{cmbs})$ and 4 (28-38 cmbs). With the exception of one hand-painted whiteware sherd collected from Level 4, the remaining datable artifacts from this unit are Colonial in origin (Table 5-4). Ceramic sherds include Goliad ware, burnished wares, sandy paste lead-glazed, Galera lead-glazed, Blue on White Huejotzingo, and polychrome tin-glazed. From 35 to 58 cmbs, the soil was a very dark grayish brown (10YR 3/2) clay loam containing small roots, pebbles and rocks (Figure 5-15). The dark clay loam was largely present in Levels 5 (38-48 cmbs) and 6 (48-58 cmbs). Three Colonial-period ceramic sherds were recovered from Level 5 including one Goliad ware, one sandy paste lead-glazed, and one Blue on White tin-glazed. Level 6 was void of cultural material and TU 2 was terminated at $58 \mathrm{cmbs}$.

\section{Test Unit $25(1-x-I-m)$}

TU 25 was located north and east of TU 2 (see Figure 4-2). A layer of gravel road base extended from the ground surface to $4 \mathrm{cmbs}$, similar to TU2. From 4 to $22 \mathrm{cmbs}$, the soil was a gray (10YR 5/1) loam with the upper $4-12 \mathrm{cmbs}$ being hard and compact. Within the gray loam, approximately 35 small to medium-sized (5-20 cm in diameter) limestone and sandstone rocks were present. Level $1(0-10 \mathrm{cmbs})$ consisted of both the road base and the compact gray loam. Artifacts recovered from Level 1 are predominantly Colonial in age; however, 15 of the 68 ceramic sherds are whitewares indicating a mix of Colonial age and nineteenth-century materials (Table 5-5). There was a dramatic increase in the number of artifacts present in Level 2 (10-20 cmbs). Once again, the cultural material is largely Colonial in age, but the presence of 20 whiteware sherds among 155 Colonial sherds demonstrates that this deposit spans the eighteenth and nineteenth centuries. One bone bead made from a small bird was recovered from Level 2, as was the lower twothirds of a copper crucifix with five clear glass sets (see description in Chapter 6). Between 22 and $32 \mathrm{cmbs}$, the soil changed slightly in color to a grayish brown (10YR 5/2) loam. This soil contained flecks of charcoal and small rock fragments and is largely present in Level 3 (20-30 cmbs). With the exception of two whiteware sherds, the remaining datable artifact assemblage originated in the Colonial period. Artifacts include 212 Colonial ceramic sherds, bone, shell, and lithics (Table 5-5). From 32 to $53 \mathrm{cmbs}$, the soil was a 
Table 5-5. Artifacts Recovered from TU 25

\begin{tabular}{|c|c|c|c|c|c|c|c|}
\hline Approximate Dates & Artifact Type & Lv. 1 & Lv. 2 & Lv. 3 & Lv. 4 & Lv. 5 & Totals \\
\hline \multirow{7}{*}{ Colonial } & Goliad ware & 30 & 112 & 165 & 47 & & 354 \\
\hline & Other unglazed & & 1 & 3 & & & 4 \\
\hline & Majolicas & 6 & 16 & 25 & 8 & & 55 \\
\hline & \begin{tabular}{|l} 
Lead-glazed \\
\end{tabular} & 16 & 26 & 18 & 13 & & 73 \\
\hline & Piloncillo molds & & & 1 & & & 1 \\
\hline & Trade beads $\&$ jewelry & & 3 & & 1 & & 4 \\
\hline & Lithic artifacts & 20 & 26 & 30 & 13 & 2 & 91 \\
\hline \multirow{2}{*}{ 18th/19th Century } & Olive glass & 1 & & 2 & & & 3 \\
\hline & Galera lead-glazed & & & 4 & & & 4 \\
\hline 19th Century & White earthenwares & 15 & 20 & 2 & 1 & & 38 \\
\hline \multirow{8}{*}{ Not Datable } & Organics: Bone & 125 & 605 & 463 & 389 & 2 & 1,584 \\
\hline & Organics: Mussel shell & 5 & 8 & 18 & 5 & & 36 \\
\hline & Organics: Marine shell & & 1 & & & & 1 \\
\hline & Construction & 6 & 19 & & & & 25 \\
\hline & Lithics (FCR) & 1 & 1 & 4 & & & 6 \\
\hline & Metal scrap & 1 & 2 & 5 & & & 8 \\
\hline & Misc. & & & & & 15 & 15 \\
\hline & Totals & 226 & 840 & 740 & 477 & 19 & 2,302 \\
\hline
\end{tabular}

very dark gray (10YR 3/1) clay loam. Level 4 (30-40 cmbs) contained numerous Colonial artifacts (Table 5-5), the majority of which were recovered from the upper 2 to $3 \mathrm{~cm}$ of Level 4. Of 69 ceramic sherds, only one undecorated whiteware sherd was collected from Level 4 . The remainder were Colonial ceramics. Artifacts recovered from Level 5 (40-53 cmbs) include bone, two lithics, and 15 very small fragments of rock and burned clay. TU 25 was terminated at $53 \mathrm{cmbs}$.

\section{Test Unit 1 (50-x-50- cm)}

TU 1 was placed adjacent to the reconstructed bastion wall in order to determine if the wall had actually been built on an existing Colonial foundation (see Figure 4-2). The excavation of TU 1 revealed that a Colonial foundation is indeed present beneath the standing wall. The Colonial foundation was designated Feature 3 (discussed below).

In TU 1, a very thin layer of pebbles or road base occurred between the ground surface and $2 \mathrm{cmbs}$ (Figure 5-16). The soil between 2 and $42 \mathrm{cmbs}$ was a dark brown loam, with the upper $6 \mathrm{~cm}(2-8 \mathrm{cmbs})$ identified as $10 \mathrm{YR} 4 / 3$ and the lower $34 \mathrm{~cm}(8-42 \mathrm{cmbs})$ as $10 \mathrm{YR} 3 / 3$. The dark brown loam was present in Levels $1-4(0-40 \mathrm{cmbs})$ and contained pebbles, rocks, roots, and a mixed artifact assemblage associated with the eighteenth through the twentieth centuries (Table 5-6). A 11/2-inch pipe running in a northsouth direction through the unit was first encountered in the south wall of TU 1 at a depth of approximately $25 \mathrm{cmbs}$. At $30 \mathrm{cmbs}$ the pipe declined vertically to a depth of $38 \mathrm{cmbs}$ at which point it runs horizontally (Figure 5-16). The installation of this pipe has resulted in the disturbance of Levels $1-4(0-40 \mathrm{cmbs})$. Between 42 and $62 \mathrm{cmbs}$, the soil was a very dark brown (10YR $2 / 2$ ) clay loam. This soil was present in Levels 5 (40-50 cmbs) and 6(50-60 cmbs). Level 5 (40-50 cmbs) contained only Colonial-period artifacts indicating the presence of an intact Colonial deposit at this depth (Table 5-6). Artifacts include 13 Goliad ware and one undecorated tin-glazed ceramic sherd, bone, shell, and lithics. No artifacts were recovered from Level 6 (50-60 cmbs). With the exception of excavating a small area adjacent to the Colonial foundation in order to fully expose the base of the foundation ( $75 \mathrm{cmbs})$, TU 1 was terminated at $62 \mathrm{cmbs}$.

\section{Feature 3}

In TU 1, a stone Colonial foundation comprised predominantly of large limestone rocks extended to a depth of $60 \mathrm{~cm}$ below the ground surface (Figure 5-17). The fill observed between the rocks consisted of a grayish brown (10YR 5/2) sandy mortar. The stone foundation appeared to terminate at $62 \mathrm{cmbs}$; however, two small limestone rocks $(10-15 \mathrm{~cm}$ in length) within a very pale brown (10YR 8/2) matrix were 


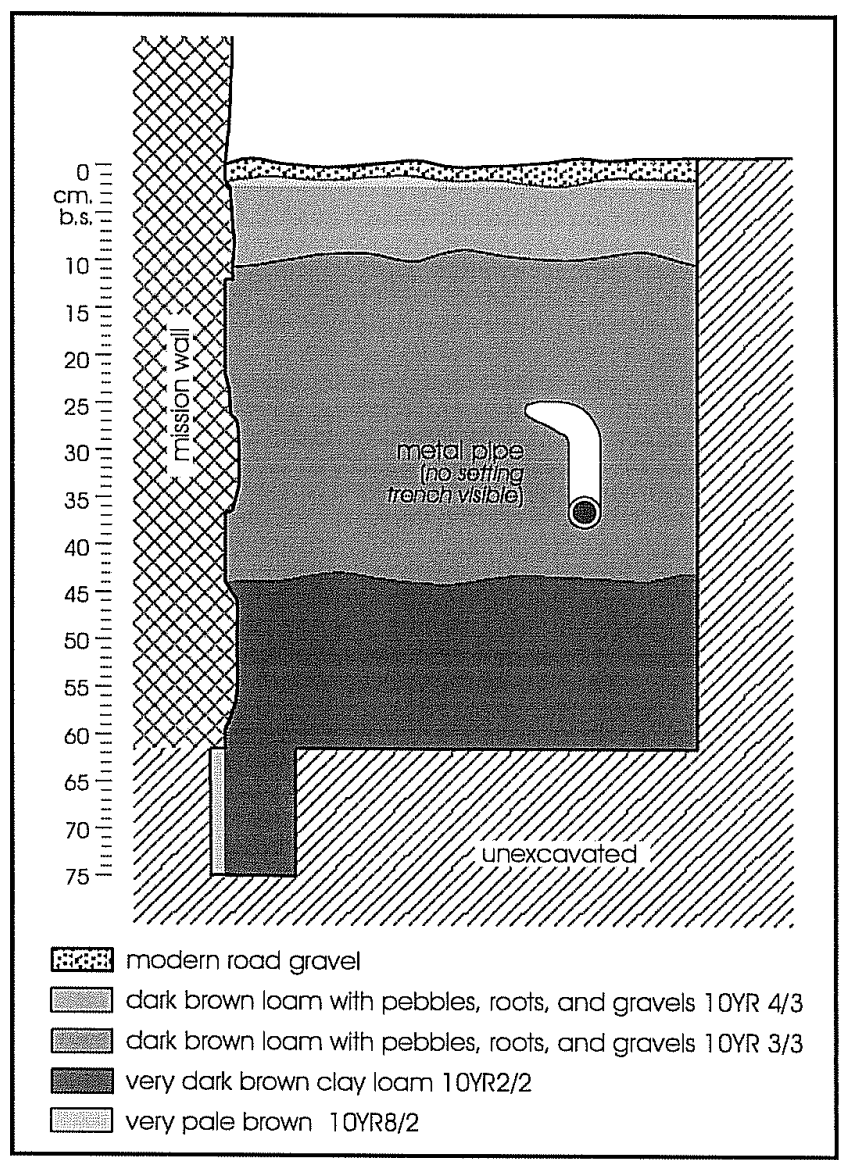

Figure 5-16. Profile of south wall of TU 1.

present to a depth of $75 \mathrm{cmbs}$ and may represent a footing for the foundation (Figure 5-17). The large limestone rocks and sandy mortar used in the construction of the stone foundation indicate that it is associated with the Colonial period and that the standing wall reconstructed above this foundation is an accurate location for one of Mission Espada's original Colonial walls.

\section{Test Unit $21(I-x-1-m)$}

TU 21 was located in the southern half of the Hike-andBike Trail near the Northwest Gateway, approximately $2 \mathrm{~m}$ west of the bastion wall (see Figure 4-2). A layer of gravel road base was present from the ground surface to approximately $6 \mathrm{cmbs}$. Level $1(0-10 \mathrm{cmbs})$ was largely comprised of this gravel road base. Few artifacts were recovered from Level 1 (Table 5-7). Between 6 and $20 \mathrm{cmbs}$, the soil was a dark gray (10YR 4/1) loam. This soil is present in the lower part of Level $1(6-10 \mathrm{cmbs})$ and in Level 2
(10-20 cmbs). With the exception of the northeast corner of TU 21, a light scatter of charcoal was observed across the entire unit in Level 2. Artifact density increased in Level 2 and the cultural material is largely Colonial in age. Of 69 ceramic sherds, only one hand-painted whiteware sherd postdates the Colonial period. Two cut nails add to the postColonial artifact inventory. Other artifacts include a solid cast copper button with a molded design, bone, shell and lithics (Table 5-7). From 20-30 cmbs, the soil consisted of a dark grayish brown (10YR 4/2) loam. This soil was present in Level 3 (20-30 cmbs). Artifact density was higher in Level 3 , compared to Level 2, and once again, the cultural material is largely Colonial in age. Of 113 ceramic sherds recovered from Level 3, one hand-painted whiteware dates to the postColonial period. One piece of plastic, one glass fragment, one unmarked stem fragment from a kaolin pipe, and one fragment of window glass add to the post-Colonial artifact inventory; while other artifacts include two glass trade beads dating to $1700-1836$, metal, bone, shell, and lithics 
Table 5-6. Artifacts Recovered from TU 1

\begin{tabular}{|c|c|c|c|c|c|c|c|}
\hline Approximate Dates & Artifact Type & Lv. 1 & Lv. 2 & Lv. 3 & Lv. 4 & Lv. 5 & Totals \\
\hline \multirow{5}{*}{ Colonial } & Goliad ware & & 4 & & 6 & 13 & 23 \\
\hline & Majolicas & & 1 & & & 1 & 2 \\
\hline & Lead-glazed & & 1 & & & & 1 \\
\hline & Trade beads \& jewelry & & & 1 & & & $\overline{1}$ \\
\hline & Lithic artifacts & 4 & & 1 & & 3 & 8 \\
\hline \multirow{3}{*}{ 18th/19th Century } & Olive glass & 1 & 2 & 3 & 1 & & 7 \\
\hline & Galera lead-glazed & & & & 1 & & 1 \\
\hline & Lamp chimney glass & & & 1 & 1 & & 2 \\
\hline \multirow{2}{*}{ 19th Century } & White earthenwares & 1 & & 7 & & & \\
\hline & "Black" glass & 1 & & 2 & & & 7 \\
\hline \multirow{2}{*}{ 20th Century } & Wire nails & & & & 2 & & 2 \\
\hline & Post 1915 Coke bottle & & & 1 & & & 1 \\
\hline \multirow{8}{*}{ Not Datable } & Organics: Bone & 2 & 37 & 54 & 20 & 102 & 215 \\
\hline & Organics: Mussel shell & & 2 & & 1 & 1 & 4 \\
\hline & Barn/Workshop & 1 & & & & & 1 \\
\hline & Construction & 4 & 1 & 5 & 1 & & 11 \\
\hline & Kitchen/Household & 10 & 8 & 5 & 2 & & 25 \\
\hline & Lithics (FCR) & & & & & 1 & 1 \\
\hline & Metal scrap & 1 & 1. & 3 & 1 & & 6 \\
\hline & Totals & 25 & 57 & 83 & 36 & 121 & 322 \\
\hline
\end{tabular}

(Table 5-7). Between 30 and $50 \mathrm{cmbs}$, the soil was a very dark grayish brown (10YR 3/2) clay loam. This soil was present in Levels 4 (30-40 cmbs) and $5(40-50 \mathrm{cmbs})$. The cultural material recovered from Levels 4 and 5 is Colonial in age, indicating the presence of an intact Colonial deposit; however, there was a dramatic decrease in the number of artifacts present within these levels (Table 5-7). Artifacts from Levels 4 and 5 include four Goliad ware, one sandy paste lead-glazed, two undecorated tin-glazed sherds, bone, and fragments of sandstone and limestone. TU 21 was terminated at $50 \mathrm{cmbs}$.

\section{Test Unit 3 (50-x-50-cm)}

TU 3 was located near the Northwest Gateway, approximately $2.5 \mathrm{~m}$ west of the standing bastion wall (see Figure 4-2). A thin layer of small pebbles extended from the ground surface to $2 \mathrm{cmbs}$. Between $2 \mathrm{~cm}$ and $31 \mathrm{cmbs}$, the soil was a dark gray (10YR 4/1) loam. This soil was present largely in Levels 1 (0-8 cmbs), 2 (8-18 cmbs), and 3 (18-28 cmbs). Artifacts recovered from Level 1 show a mix of eighteenthand nineteenth-century materials including Goliad ware, sandy paste lead-glazed, tin-glazed, European porcelain and whiteware ceramic sherds, bone, shell, and an iron fragment
(Table 5-8). From 31 to $48 \mathrm{cmbs}$, the soil was a very dark grayish brown (10YR 3/2) clay loam. This soil was largely present in Levels 4 (28-38 cmbs) and 5 (38-48 cmbs). Levels 2 through 4 contained only Colonial-period artifacts indicating the presence of an intact Colonial deposit in this area of the mission. The Colonial artifact types recovered from these levels are restricted to ceramics, bone, shell, lithics, and jewelry. One finger ring made of copper or brass with a clear glass set was collected from Level 3 (see description in Chapter 6). Colonial ceramics consist of the following: Goliad ware, lead-glazed (sandy paste and Galera), Black Luster, Tonalá Burnished, and San Agustín tin-glazed. Artifact density decreased in Level 4 (28-38 cmbs) correlating with a change in soil from a dark gray loam to a very dark grayish brown clay loam at approximately $31 \mathrm{cmbs}$. Level 5 (38-48 cmbs) was void of cultural material and TU 3 was terminated at 48 cmbs.

\section{Test Unit $24(1-x-1-m)$}

TU 24 was located in the southern half of the Hike-andBike Trail approximately $1.25 \mathrm{~m}$ west of the standing bastion wall (see Figure 4-2). From the ground surface to $25 \mathrm{cmbs}$, the soil was comprised of a dark gray (10YR 4/1) loam. 
Pebbles, rootlets, and small fragments of sandstone were found scattered throughout this soil. The dark gray loam was present in Levels $1(0-10 \mathrm{cmbs})$ and $2(10-20 \mathrm{cmbs})$, and the upper $5 \mathrm{~cm}$ of Level $3(20-25 \mathrm{cmbs})$. Artifacts recovered from Level 1 show a mix of eighteenth- to earlytwentieth-century materials, including Goliad ware, burnished, lead- and tin-glazed, and whiteware ceramic sherds, glass fragments, window glass, metal, sandstone fragments, bone, and lithics (Table 5-9). Of 104 ceramic sherds collected from Level 1, 97 belong to the Colonial period and the remaining seven whiteware sherds are postColonial in age. The cultural material collected from Level 2 (10-20 cmbs) shows a predominance of Colonial-age artifacts. With the exception of two ceramic sherds (one whiteware and one European porcelain) and two wire nails, there are 195 Colonial ceramic sherds, lithics, bone, shell, and metal fragments. From 25 to $40 \mathrm{cmbs}$, the soil was a very dark gray (10YR 3/1) clay loam. This soil was present in the lower half of Level 3 (25-30 cmbs) and Level 4 (30$40 \mathrm{cmbs})$. The number of artifacts dramatically decreased in Level 3 (20-30 cmbs); however, the artifact assemblage indicates that the cultural material is Colonial in age (Table 5-9). Ceramics include Goliad ware, Valero, sandy paste lead-glazed, and Galera and Huejotzingo tin-glazed sherds. Level 4 ( $30-40 \mathrm{cmbs}$ ) was void of cultural material and TU 24 was terminated at $40 \mathrm{cmbs}$.

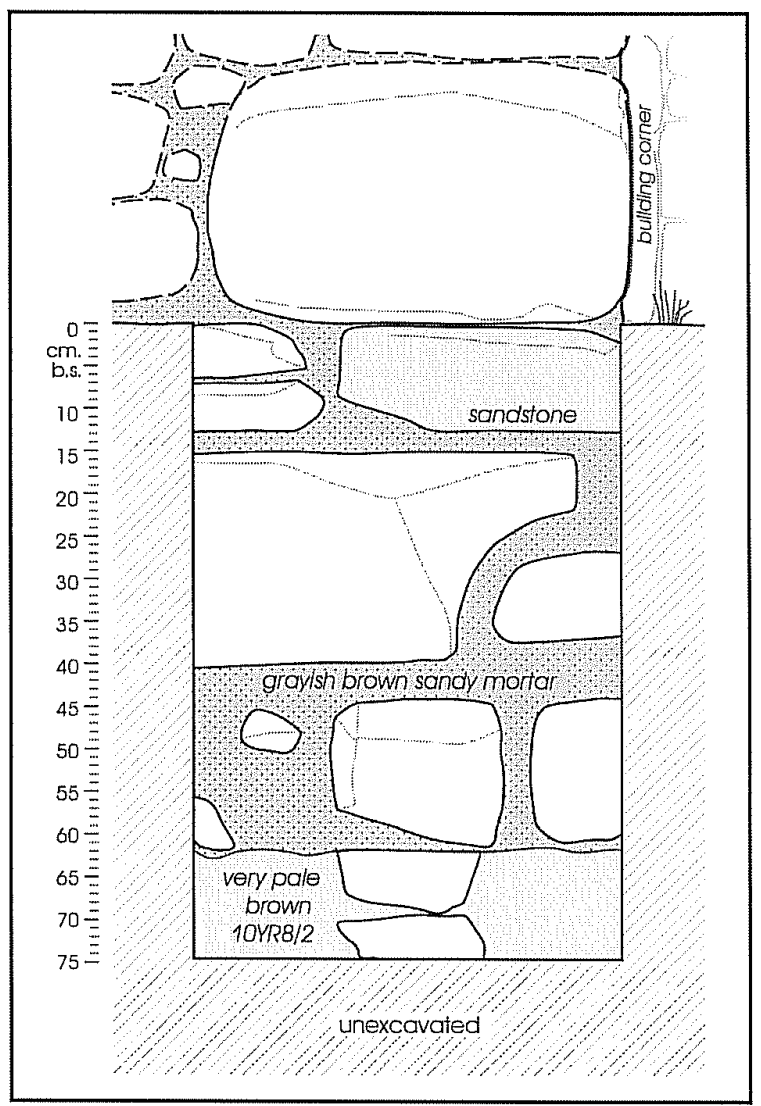

Figure 5-17. East wall of TU 1, showing Colonial wall foundation with reconstructed wall above.

Table 5-7. Artifacts Recovered from TU 21

\begin{tabular}{|c|c|c|c|c|c|c|c|}
\hline Approximate Dates & Artifact Type & Lv. 1 & Lv. 2 & Lv. 3 & LV. 4 & Lv. 5 & Totals \\
\hline \multirow{5}{*}{ Colonial } & Goliad ware & 1 & 55 & 87 & 2 & 2 & 147 \\
\hline & Majolicas & & 2 & 9 & 2 & & 13 \\
\hline & Lead-glazed & 1 & 11 & 11 & 1 & & 24 \\
\hline & Trade beads \& jewelry & & & 2 & & & 2 \\
\hline & Lithic artifacts & & 7 & 15 & & & 22 \\
\hline \multirow{2}{*}{ 18th/19th Century } & Clay pipe fragment & & & 1 & & & 1 \\
\hline & Galera lead-glazed & & 1 & 5 & & & 6 \\
\hline \multirow{2}{*}{ 19th Century } & White earthenwares & & 1 & 1 & & & 2 \\
\hline & Cut nails & 1 & 2 & & & & 3 \\
\hline \multirow{8}{*}{ Not Datable } & Organics: Bone & 17 & 277 & 817 & 54 & 13 & 1,178 \\
\hline & Organics: Mussel shell & & 4 & 9 & & & 13 \\
\hline & Organics: Marine shell & & I & 1 & & & 2 \\
\hline & \begin{tabular}{|l|} 
Construction \\
\end{tabular} & & 19 & 6 & & & 25 \\
\hline & Kitchen/Household & & 1 & 1 & & & 2 \\
\hline & Personal & & 1 & & & & 1 \\
\hline & Metal scrap & & & 1 & & $\mathrm{l}$ & 2 \\
\hline & Misc. & 2 & & 1 & & & 3 \\
\hline Totals & & 22 & 382 & 967 & 59 & 16 & 1,446 \\
\hline
\end{tabular}


Table 5-8. Artifacts Recovered from TU 3

\begin{tabular}{|c|c|c|c|c|c|c|}
\hline Approximate Dates & Artifact Type & Lv. 1 & Lv. 2 & Lv. 3 & Lv. 4 & Totals \\
\hline \multirow{6}{*}{ Colonial } & Goliad ware & 2 & 20 & 27 & 5 & 54 \\
\hline & Other unglazed & & & 1 & & 1 \\
\hline & Majolicas & 2 & & 2 & & 4 \\
\hline & Lead-glazed & 3 & 3 & 4 & 1 & 11 \\
\hline & Trade beads \& jewelry & & & 1 & & 1] \\
\hline & Lithic artifacts & & 1 & 3 & 1 & ગ \\
\hline 18th/19th Century & Galera lead-glazed & . & 2 & & & 2 \\
\hline 19th Century & White earthenwares & 1 & & & & 1] \\
\hline \multirow{4}{*}{ Not Datable } & Organics: Bone & 23 & 58 & 244 & 120 & 445 \\
\hline & Organics: Mussel shell & 1 & 1 & 6 & & 8 \\
\hline & Kitchen/Household & 4 & & & & 4 \\
\hline & Lithics (FCR) & & & & 1 & 1 \\
\hline & Totals & 36 & 85 & 288 & 128 & 537 \\
\hline
\end{tabular}

Table 5-9. Artifacts Recovered from TU 24

\begin{tabular}{|c|c|c|c|c|c|}
\hline Approximate Dates & Artifact Type & Lv. 1 & Lv. 2 & Lv. 3 & Totals \\
\hline \multirow{6}{*}{ Colonial } & Goliad ware & 52 & 160 & 18 & 230 \\
\hline & Other unglazed & 1 & 3 & 1 & $\overline{5}$ \\
\hline & Majolicas & 18 & 3 & 2 & 23 \\
\hline & Lead-glazed & 25 & 29 & 2 & 56 \\
\hline & Cliapatone & 1 & & & 1 \\
\hline & Lithic artifacts & & 43 & 5 & $\overline{48}$ \\
\hline \multirow{2}{*}{ 18th/19th Century } & Olive glass & 3 & & & 3 \\
\hline & Galera lead-glazed & 1 & & 2 & 3 \\
\hline 19th Century & White earthenwares & 7 & 2 & & $\overline{9}$ \\
\hline Late 19 th/Early 20 th & Clear glass (manganese) & 1 & & & 1 \\
\hline 20th Century & Wire nails & & 2 & & 2 \\
\hline \multirow{7}{*}{ Not Dateable } & Organics: Bone & 378 & 860 & 336 & 1,574 \\
\hline & Organics: Mussel shell & 9 & 10 & 2 & 21 \\
\hline & Construction & 8 & & 2 & 10 \\
\hline & Kitchen/Household & 14 & & & $\overline{14}$ \\
\hline & Lithics (FCR) & & & 1 & 1 \\
\hline & Metal scrap & 6 & 2 & & 8 \\
\hline & Misc. & 1 & & 6 & 7 \\
\hline & Totals & 525 & 1,114 & 377 & 2,016 \\
\hline
\end{tabular}

\section{Test Unit 4 (50-x-50-cm)}

TU 4 was one of the $14(50-x-50-\mathrm{cm})$ units set up to initially test the project area for intact Colonial deposits. It was located in the southern part of the project area, approximately $5 \mathrm{~m}$ from the mission compound wall (see Figure 4-2). From the ground surface to $25 \mathrm{cmbs}$, the soil was comprised of a gray (10YR 5/1) loam containing roots, small fragments of sandstone, and flecks of charcoal. Charcoal was more concentrated in the southwest portion of the unit than elsewhere in TU 4. The gray loam was present in Levels 1 (0-10 cmbs) and $2(10-20 \mathrm{cmbs})$, and the upper $5 \mathrm{~cm}$ of Level 3 (20-25 cmbs). Artifacts recovered from Levels 1 and $2(0-20 \mathrm{cmbs})$ show a mix of eighteenth- through twentieth-century materials including Goliad ware, burnished, lead-glazed, tin-glazed and whiteware ceramic sherds, glass fragments, window glass, wire nails, bone, and lithics (Table 5-10). 
Table 5-10. Artifacts Recovered from TU 4

\begin{tabular}{|c|c|c|c|c|c|c|}
\hline Approximate Dates & Artifact Type & Lv. 1 & Lv. 2 & Lv. 3 & Lv. 4 & Totals \\
\hline \multirow{6}{*}{ Colonial } & Goliad ware & 6 & 13 & 8 & 1 & 28 \\
\hline & Other unglazed & 3 & & & & 3 \\
\hline & \begin{tabular}{|l} 
Majolicas \\
\end{tabular} & 5 & 1 & & 1 & 7 \\
\hline & Lead-glazed & 2 & 3 & 3 & 1 & 9 \\
\hline & Trade beads \& jewelry & & 1 & & & 1 \\
\hline & Lithic artifacts & & 3 & & & 3 \\
\hline \multirow{2}{*}{ 18th/19th Century } & Olive glass & 9 & 1 & 1 & 2 & 13 \\
\hline & Galera lead-glazed & 3 & & & & 3 \\
\hline \multirow{3}{*}{ 19th Century } & White earthenwares & 8 & 3 & & 1 & 12 \\
\hline & "Black" glass & & 1 & & & 1 \\
\hline & Cut nails & & 1 & & & 1 \\
\hline \multirow{2}{*}{ 20th Century } & Clear glass (selenium) & 1 & & & & 1 \\
\hline & Wire nails & & 2 & & & 2 \\
\hline \multirow{6}{*}{ Not Datable } & Organics: Bone & 55 & 78 & 75 & 18 & 226 \\
\hline & Organics: Mussel shell & 3 & 2 & 2 & & 7 \\
\hline & Construction & 1 & 1 & 1 & & 3 \\
\hline & Kitchen/Household & 10 & 1 & 2 & 1 & 14 \\
\hline & Metal scrap & 1 & 2 & & & 3 \\
\hline & Totals & 107 & 113 & 92 & 25 & 337 \\
\hline
\end{tabular}

Between 25 and $50 \mathrm{cmbs}$, the soil was a very dark grayish brown (10YR 3/2) clay loam containing small roots, very few flecks of charcoal, and small fragments of limestone. This soil was present in the lower $5 \mathrm{~cm}$ of Level 3 (25-30 cmbs), and in Levels 4 (30-40 cmbs) and 5 (40-50 cmbs). There was a decrease in artifact density and artifact type in Levels 3 and 4 compared to Levels 1 and 2 (Table 5-10). Ceramic sherds collected from Levels 3 and 4 include only one whiteware sherd from the post-Colonial period. The other sherds are Colonial in age and consist of Goliad ware, sandy paste lead-glazed, and one undecorated tin-glazed. In addition to the ceramics, artifacts recovered from Levels 3 and 4 include glass fragments, bone, shell, and one brick/ tile fragment. While there was a higher density of Colonial artifacts in Levels 3 and 4, the glass fragments and whiteware sherd suggest some disturbance of these lower levels. Level $5(40-50 \mathrm{cmbs})$ yielded no artifacts and TU 4 was terminated at $50 \mathrm{cmbs}$.

\section{Test Units 5 (50-x-50-cm), 17, 22, and $26(1-x-1-m)$}

These four units were adjacent to one another and were located in the southern section of the project area with TU 22 located only about $1.5 \mathrm{~m}$ west of the mission compound wall (see Figure 4-2). TU 5 was one of the 14 (50-x-50-cm) units set up to initially test the project area for intact Colonial deposits. TU 5 was shown to contain intact materials; therefore, TUs 17,22 , and 26 were subsequently excavated. Table 5-11 is a list of artifacts recovered from all four units.

\section{Test Units 5 and 17}

While the soil stratigraphy observed in TUs $5(50-x-50$ $\mathrm{cm})$ and $17(1-\mathrm{x}-1-\mathrm{m})$ was similar, intact Colonial deposits were observed in TU 5 but not in TU 17 (Table 5-11). The mixing of materials in TU 17 is due to the presence of a metal pipe that runs in a north/south direction at a depth of $37 \mathrm{cmbs}$ (Figure 5-18). From the ground surface to approximately $8 \mathrm{cmbs}$, the soil was comprised of a yellowish brown (10YR 5/4) clay mixed with gravels. This matrix was present in Level 1 of TU 5 (0-8 cmbs) and TU 17 (0-10 cmbs). Recovered artifacts represent a mix of eighteenththrough twentieth-century materials including Colonial and post-Colonial ceramics, window glass, lithics, and plastic (Table 5-11). One shell button (1 cm in diameter with two holes) which dates to the last part of the nineteenth to the early twentieth century was recovered from TU 17 , and one pin/button consisting of a metal disk with a pin attached to the back (similar to those handed out by politicians during campaigns) was collected from TU 5. Between approximately 8 and $28 \mathrm{cmbs}$, the soil was a gray (10YR 5/1) loam containing a small amount of pebbles. This gray loam was present in Levels 2 and 3 of TU 5 ( $8-28 \mathrm{cmbs})$ and TU 17 (10-30 cmbs). Artifacts recovered from Level 2 in TUs 5 


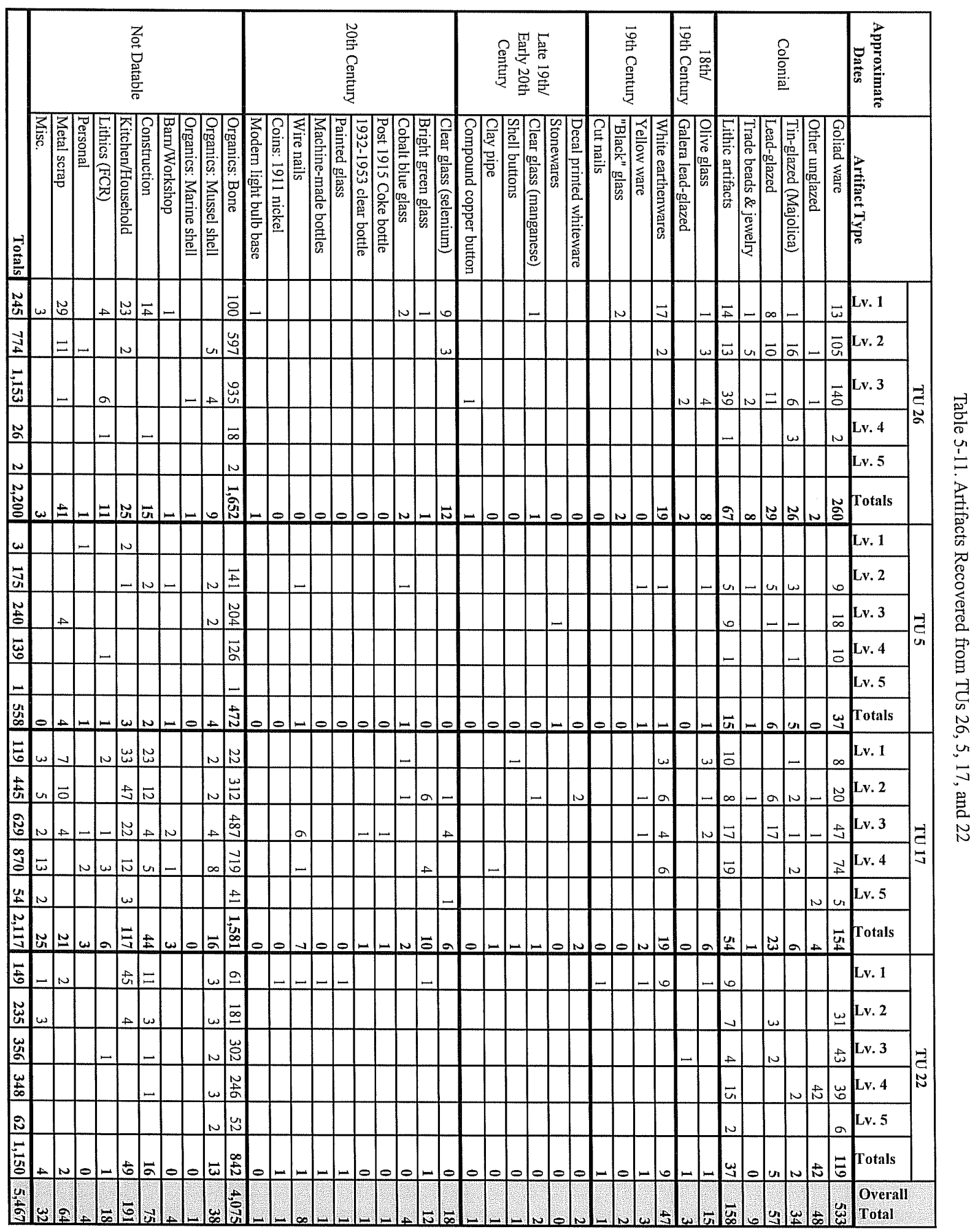




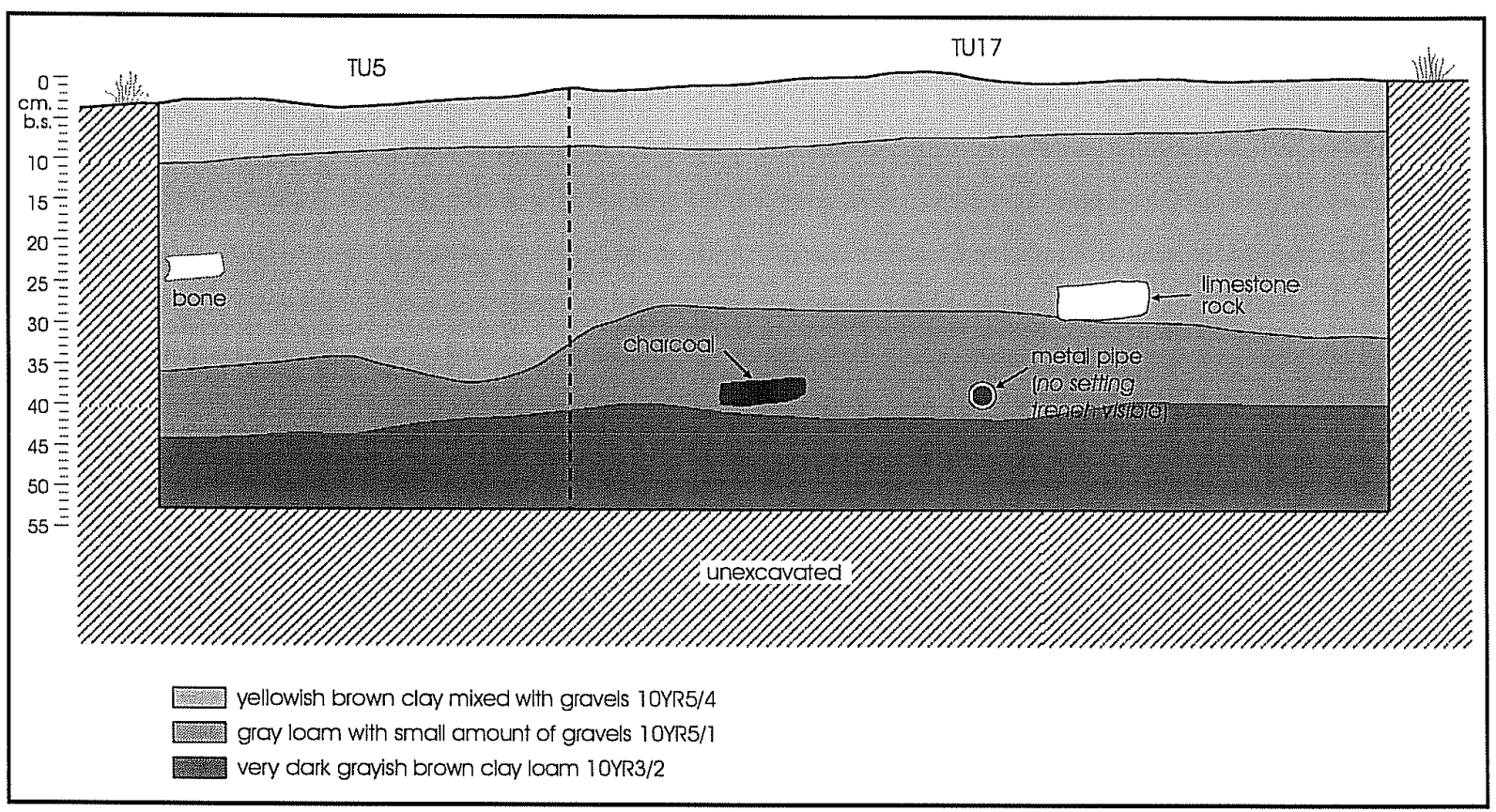

Figure 5-18. Profile of the north wall of TUs 5 and 17.

(8-18 cmbs) and $17(10-20 \mathrm{cmbs})$ reflect the same mix of materials found in Level 1. While the majority of recovered ceramics are from the Colonial period; whitewares, yellow ware, and European porcelain are also present, as are numerous fragments of glass, and wire nails. One blue glass trade bead from the Colonial period was recovered from TU 5 and one Colonial earring with a glass set was recovered from TU 17. It was in TU 5, Level 3 $(18-28 \mathrm{cmbs})$ that an intact Colonial deposit was identified. With the exception of one sherd of Albany slip stoneware, the remaining ceramic sherds include 18 Goliad ware, one sandy paste lead-glazed, and one San Elizario tin-glazed. Other artifacts recovered from Level 3 include bone, shell, and lithics; including one Guerrero point fragment. Level $3(20-30 \mathrm{cmbs})$ of TU 17 continued to show disturbed materials including numerous Colonial ceramics, a modern glass bottle (at $30 \mathrm{cmbs}$ ), window glass, and wire nails. From $28-40 \mathrm{cmbs}$, the soil changed slightly in color and texture from a gray loam to a dark gray (10YR 4/1) loam with a slightly higher clay content (Figure 5-18). Level 4 of TU 5 (28-38 cmbs) and TU 17 $(30-40 \mathrm{cmbs})$ was present within the dark gray loam. TU 5 , Level 4, continued to demonstrate the existence of an intact Colonial deposit represented by 10 Goliad ware sherds and one Blue on White tin-glazed sherd, bone, and one lithic. Level 4 of TU 17 contained a mix of eighteenth- through twentieth-century materials including numerous Colonial and post-Colonial ceramics, glass fragments, lithics, a Guerrero point, a wire nail, and iron scrap. In Level 4 of TU 17 , a metal pipe was observed at $37 \mathrm{cmbs}$ rumning in a northsouth direction through the unit. No setting trench for this pipe was visible in either the north or the south wall profiles. The pipe was $1 \frac{1 / 2}{2}$ inches in diameter and was the same pipe encountered in TU 1. From $40-50 \mathrm{cmbs}$, the soil was a very dark grayish brown (10YR 3/2) clay loam. Level 5 of TUs 5 (38-48 cmbs) and TU $17(40-50 \mathrm{cmbs})$ was comprised of this soil. Two bone fragments were recovered from Level 5 of TU 5, and TU 5 was terminated at $48 \mathrm{cmbs}$. In TU 17, Level 5 (40-50 cmbs) artifacts dramatically decreased in number. They consist of five Goliad ware and two Valero sherds, four post-Colonial glass fragments, bone, and sandstone fragments (Table 5-11). TU 17 was terminated at the base of Level 5 ( $50 \mathrm{cmbs})$.

\section{Test Unit 22}

TU 22 was a $1-\mathrm{x}-1-\mathrm{m}$ unit located adjacent and east of TU 17 (see Figure 4-2). From the ground surface to $3 \mathrm{cmbs}$, the soil was a grayish brown (10YR 5/2) loam containing grass, small roots and pebbles, and modern glass. From $3 \mathrm{~cm}$ to approximately $36 \mathrm{cmbs}$, the soil was a dark grayish brown (10YR 4/2) loam with small roots and pebbles. This soil was present in Levels 1 through 3 and the upper part of Level 4. A mix of eighteenth- through twentieth-century 
artifacts were recovered from Level $1(0-10 \mathrm{cmbs})$ including Goliad ware and whiteware ceramic sherds, glass fragments, one cut and one wire nail, a 1911 nickel, and lithics (Table 5-11). The artifacts collected from Level 2 (10-20 cmbs) are largely Colonial in origin; however, the presence of a bottle cap and five glass fragments indicate that Level 2 was moderately disturbed. With the exception of a single piece of window glass recovered from Level $3(20-30 \mathrm{cmbs})$, the remaining artifacts appear to be entirely Colonial in age. In addition to Goliad ware, and sandy paste and Galera leadglazed ceramic sherds, artifacts include bone, shell, and lithics (Table 5-11). Numerous flecks of charcoal were observed near the bottom of Level 3, especially in the northwest corner of the unit. There was an increase in the number of ceramics present in Level 4 (30-40 cmbs) compared to Levels $1-3$. The artifact assemblage in Level 4 continued to exhibit Colonial age artifacts including Goliad ware and tin-glazed ceramic sherds, bone, shell, and lithics. Three Guerrero points were collected from this level (see Chapter 6). From $36-60 \mathrm{cmbs}$, the soil was a very dark grayish brown (10YR 3/2) clay loam containing small amounts of roots and pebbles. This soil was present in the lower part of Level 4 , and in Levels 5 and 6 . Artifacts greatly decreased in Level $5(40-50 \mathrm{cmbs})$ and only a few Colonial-age artifacts were recovered including six Goliad ware sherds and two lithics (Table 5-11). Level 6 (50-60 cmbs) was sterile and excavation of TU 22 was terminated at $60 \mathrm{cmbs}$.

\section{Test Unit 26}

TU 26 was a 1-x-1-m unit located adjacent and west of TU 5 (see Figure 4-2). From the ground surface to $22 \mathrm{cmbs}$, the soil was comprised of a gray (10YR 5/1) loam containing small roots. This soil was present in Levels 1 and $2(0-20$ cmbs). Artifacts from Level $1(0-10 \mathrm{cmbs})$ show a mix of eighteenth- through twentieth-century materials including Goliad ware, lead-glazed, tin-glazed, and whiteware ceramic sherds, glass and window glass fragments, lithics, and one dark blue glass trade bead dating to from 1700-1836. The majority of artifacts recovered from Level 2 (10-20 cmbs) are Colonial in age. Of 134 ceramic sherds, only two sherds of whiteware were collected while the remaining 132 consist of Goliad ware, unglazed, lead-glazed and tin-glazed sherds. Post-Colonial artifacts include colorless glass fragments that have been sun-stained yellow (indicating use of selenium as a decolorizer, a twentieth-century practice), and a shoelace eyelet. Three Colonial beads were collected from Level 2 , one of which is a square, black jet rosary bead ( $7 \mathrm{~mm}$ square) and two medium blue glass trade beads. The distal end of a projectile point was also recovered.
A light lens of charcoal was present between approximately 22-27 cmbs and this charcoal lens comprised part of Level $3(20-30 \mathrm{cmbs})$. There was an increase in the number of artifacts recovered from Level 3, compared to Levels 1 and 2 (Table 5-11). The artifacts collected from Level 3 all appear to be entirely Colonial in age. One hundred and sixtysix ceramic sherds are typed as follows: Goliad ware, unglazed, sandy paste lead-glazed, Galera, and tin-glazed (San Elizario, Blue on White, Blue on Blue, and undecorated). A Colonial copper button with a drilled shank and a gunflint were also recovered. Other artifacts from Level 3 consist of olive glass fragments, bone, shell, and 39 lithics.

From $27-50 \mathrm{cmbs}$ the soil was a very dark gray (10YR 3/1) clay loam. This soil was largely present in Levels 4 (30-40 $\mathrm{cmbs})$ and $5(40-50 \mathrm{cmbs})$. The cultural material recovered from Levels 4 and 5 continued to represent the Colonial period; however, artifact density dramatically decreased with depth (Table 5-11). Five ceramic sherds (two Goliad ware and three Blue on White tin-glazed), bone, and three lithics were recovered from Level $4(30-40 \mathrm{cmbs})$, and two bone fragments were collected from Level $5(40-50 \mathrm{cmbs})$. The excavation of TU 26 was terminated at $50 \mathrm{cmbs}$.

\section{Test Units 6, 15 (50-x-50-cm), and $19(1-x-1-m)$}

TUs 6,15 , and 19 were located approximately $5 \mathrm{~m}$ west of the mission compound wall (see Figure 4-2). TU 6 was excavated as part of the original grid of $50-x-50-\mathrm{cm}$ test units along the Hike-and-Bike Trail. In Level 2 of this unit a number of large sandstone and limestone rocks were noted. As a result, TU $15(50-\mathrm{x}-50-\mathrm{cm})$ was placed adjacent and to the east of TU 6 . TU $19(1-\mathrm{x}-1-\mathrm{m})$ was then placed to the southwest of TU 6 in order to determine if the large rocks continued in that direction.

The large rocks did not continue into TU 15 but covered most of Level 2 in TU 19. In this larger unit, however, it was easier to see that the rocks in question did not form a foundation or other such structural feature. They appeared to be a scatter of discarded rubble. The mixture of eighteenthto twentieth-century artifacts apparent among the rocks suggests that the rubble was either very disturbed or from a fairly recent construction episode.

Sediments in TUs 6 and 19 consisted of a gray (10YR 5/1) loam extending from the ground surface to $26 \mathrm{cmbs}$. The gray loam was present in Levels 1 through 3 (0-28 cmbs). 
The loam contained pebbles, small roots, charcoal, and a mix of eighteenth- to twentieth-century artifacts including Colonial and post-Colonial ceramic sherds, lithics, glass, and wire nails (Table 5-12). In addition, medium to large size (10-20 cm in diameter) limestone and sandstone rocks, observed primarily in Levels 2 and $3(8-28 \mathrm{cmbs})$ of TUs 6 and 19 , were identified within the gray loam and designated
Feature 2 (discussed below). The excavation of TU 6 was terminated at the base of Level $3(28 \mathrm{cmbs})$ and TU 19 was dug to a depth of $58 \mathrm{cmbs}$. Lying directly below the gray loam in TU 19 was a dark gray (10YR 4/1) loam which extended from 26-58 cmbs. Small roots, charcoal, and pebbles were present in Levels 4 through $6(28-58 \mathrm{cmbs})$. The mix of Colonial through twentieth-century artifacts

Table 5-12. Artifacts Recovered from TUs 6, 15, and 19

\begin{tabular}{|c|c|c|c|c|c|c|c|c|}
\hline Approximate Dates & Artifact Type & Lv. 1 & Lv. 2 & Lv. 3 & Lv. 4 & Lv. 5 & Lv. 6 & Totals \\
\hline \multirow{6}{*}{ Colonial } & Goliad ware & 3 & 7 & 10 & 25 & 1 & 1 & 47 \\
\hline & Other unglazed & & & & 1 & & & 1 \\
\hline & Majolicas & & 3 & 2 & & 1 & & 6 \\
\hline & Lead-glazed & 1 & 1) & 2 & 1 & & 1 & 6 \\
\hline & Piloncillo molds & & & 1 & & & & 1 \\
\hline & Lithic artifacts & 6 & 5 & 3 & 2 & 1 & 1 & 18 \\
\hline \multirow{3}{*}{ 18th/19th Century } & Olive glass & 4 & 2 & & & & & 6 \\
\hline & Galera lead-glazed & & . & & & 1 & 1 & 2 \\
\hline & Lamp chimney glass & & 2 & 3 & & & & 5 \\
\hline \multirow{6}{*}{ 19th Century } & White earthenwares & 2 & 40 & 14 & 2 & 1 & & 59 \\
\hline & Yellow ware & & 5 & 1 & & & & 6 \\
\hline & "Black" glass & & 1 & 2 & & & & 3 \\
\hline & Bottle molded w/ applied lip & & 1 & 1 & & & & 2 \\
\hline & Cut nails & 1 & & 3 & 4 & & & 8 \\
\hline & Slate & 1 & & & & & & 1 \\
\hline \multirow{6}{*}{$\begin{array}{c}\text { Late } 19 \text { th/Early } 20 \text { th } \\
\text { Century }\end{array}$} & Tea leaf ironstone & & & 1 & & & & 1 \\
\hline & Stonewares & 1 & 6 & 1 & & & & 8 \\
\hline & Clear glass (manganese) & & 4 & 4 & & & & 8 \\
\hline & Milk bottles & & 1 & & & & & 1 \\
\hline & Bitters bottle & & 1 & & & & & 1 \\
\hline & Panel bottle & & & 1 & & & & 1 \\
\hline \multirow{5}{*}{ 20th Century } & Clear glass (selenium) & & 20 & 2 & & 1 & & 23 \\
\hline & Bright green glass & 1 & 2 & & 1 & & & 4 \\
\hline & Cobalt blue glass & 1 & & 1 & & & & 2 \\
\hline & Machine made glass & & 1 & 1 & & & & 2 \\
\hline & Wire nails & 5 & & 18 & & & & 23 \\
\hline \multirow{9}{*}{ Not Datable } & Organics: Bone & 10 & 73 & 115 & & 14 & 16 & 228 \\
\hline & Organics: Mussel shell & 2 & 8 & 3 & & & & 13 \\
\hline & Activities & & & 1 & & & & 1 \\
\hline & Barn/Workshop & & 3 & 6 & & & & 9 \\
\hline & Construction & 8 & 31 & 10 & 27 & & & 76 \\
\hline & Kitchen/Household & 25 & 86 & 22 & 2 & 174 & & 309 \\
\hline & Personal & & 4 & & & & & 4 \\
\hline & Metal scrap & 2 & 34 & 89 & 9 & 1 & & 135 \\
\hline & Misc. & 1 & 1 & 1 & . & & & 3 \\
\hline & Totals & 74 & 342 & 318 & 74 & 195 & 20 & 1,023 \\
\hline
\end{tabular}


observed in Levels 1-3 contained in Level 4 (28-38 cmbs). Level 4 contained Colonial ceramics as well as two whiteware sherds, window glass, and modern glass fragments. While the number of artifacts greatly decreased in Levels 5 and 6 (38-58 cmbs), the cultural material was Colonial in age with the exception of one whiteware sherd in Level 5. The artifacts observed were located in the northeast quadrant of TU 19 in association with some charcoal and bone, and limestone and sandstone rock (rock first noted at $46 \mathrm{cmbs}$ continuing into Level 6). The soil surrounding the rocks was a $10 \mathrm{YR} 4 / 2$ clay loam. This lower rock first observed near the bottom of Level 5 was separated from Feature 2 by approximately $16 \mathrm{~cm}$.

As mentioned above, TU 15 was located adjacent and east of TU 6, but appeared to have different sediments. In TU 15 , a very dark grayish brown (10YR 3/2) clay loam extended from the ground surface to $43 \mathrm{cmbs}$. This homogenous soil was observed in Levels $1-4$ (0-38 cmbs) and the upper $5 \mathrm{~cm}$ of Level 5 (38-43 cmbs). Between 43 and $48 \mathrm{cmbs}$ (base of excavation) the soil was a dark grayish brown (10YR 4/2) clay loam. Feature 2 (observed in TUs 6 and 19) did not extend east into TU 15 . Small pebbles, roots, and charcoal flecks were found throughout Levels 1-4 (0 $38 \mathrm{cmbs})$. In Levels $1-3(0-28 \mathrm{cmbs})$ a mix of eighteenthto twentieth-century artifacts were present indicating that the upper $28 \mathrm{~cm}$ of this unit was disturbed. Cultural material recovered from Levels 4 (28-38 cmbs) and 5 (38-48 cmbs) was restricted to the Colonial period. Level 4 contained two pieces each of mortar and sandstone, one Goliad ware sherd, and animal bone. Charcoal and bone was observed between $38-45 \mathrm{cmbs}$ in the northwest quadrant of TU 15 and animal bone was the only cultural material collected from Level 5 (38-48 cmbs). While the number of artifacts decreased in Levels 4 and 5, the material indicates that between 28 and $48 \mathrm{cmbs}$, an intact Colonial deposit was present.

\section{Feature 2}

Large limestone and sandstone rocks were encountered during concurrent excavation in two separate areas in the location of the Hike-and-Bike Trail and designated Feature 1 and Feature 2. Feature 1 was present in TUs 12,16 , and 18 (discussed below) and Feature 2 was encountered in TUs 6,15 , and 19. These two features were aligned in a north/ south direction, parallel to, and approximately $6 \mathrm{~m}$ west of the northwest mission compound wall. Initially, the presence of large rock in this area was thought to be a possible foundation wall; however, further excavation revealed that Features 1 and 2 represent discarded rock. Furthermore, the excavation of TUs 8, 10, and 20 located between Features
1 and 2 on the same north/south line failed to yield similar rock; negating the presence of a contiguous wall. Cultural material was found intermixed with un-mortared rocks indicating that either rock was discarded in an area previously containing cultural material, or that both rock and artifacts were redeposited together.

Feature 2 was comprised of medium to large-sized (10-20 $\mathrm{cm}$ in length) limestone and tabular sandstone rocks observed in TUs 6 and 19. A few medium-sized rocks were first observed in Level $1(0-8 \mathrm{cmbs})$ in the central portion of TU 19; however, Feature 2 became prominent and well defined in Level 2 (8-18 cmbs), extending into Level 3 (18$28 \mathrm{cmbs}$ ) in both TUs 6 and 19. The depth of Feature 2 varied between 28 and $31 \mathrm{cmbs}$. In TU 19, approximately 30 rocks were removed from Level $2(8-18 \mathrm{cmbs})$, and 70 ( 50 of which were limestone and 20 of sandstone) from Level 3 (18-28 cmbs). Interspersed among the rocks of Feature 2 were roots, pebbles, bone, charcoal, lithics, ceramics and other artifacts. The rocks showed no evidence of mortar or articulation, and mixed cultural material dating from the eighteenth, nineteenth and twentieth centuries indicates that Feature 2 may represent discarded material from a period of mission reconstruction. Feature 2 appeared to extend north and west of TUs 6 and 19, and south of TU 19 .

\section{Test Unit 7 (50-x-50-cm)}

TU 7 was located approximately $3.5 \mathrm{~m}$ west of the mission compound wall (see Figure 4-2). TU 7 was one of the 14 units set up to initially test the project area for intact Colonial deposits. With the exception of a 2-cm layer of pebbles at the ground surface, the soil was comprised of a homogenous dark gray (10YR 4/1) loam which varied in depth from 2 to $15 \mathrm{cmbs}$ in the south end of the unit and from 2 to $30 \mathrm{cmbs}$ in the north end of the unit. This soil was largely present in Levels $1-3$ and contained roots, pebbles, charcoal and mortar. Some larger cobbles $(10 \mathrm{~cm}$ in diameter) were observed at the bottom of Level $1(0-8 \mathrm{cmbs})$ and charred wood fragments were present in Level 2 (8-18 cmbs). Artifacts recovered from Levels $1-3(0-28 \mathrm{cmbs})$ show a mix of eighteenth- through twentieth-century materials including Goliad ware, sandy paste lead-glazed, and whiteware sherds, cut and wire nails, a plastic hairbrush fragment, a white porcelain button, and remains of early-twentiethcentury bottles (Table 5-13). Between $15 \mathrm{cmbs}$ (south end of the unit), and $30 \mathrm{cmbs}$ (north end of the unit), extending to a depth of $38 \mathrm{cmbs}$ (base of unit), the soil was a dark gray (10YR 4/1) clay loam. While the soil color remained unchanged from the surface to the base of the unit, a change in soil texture and the absence of cultural material served to 
Table 5-13. Artifacts Recovered from TU 7

\begin{tabular}{|c|c|c|c|c|c|}
\hline Approximate Dates & Artifact Type & Lv. 1 & Lv. 2 & Lv. 3 & Totals \\
\hline \multirow{4}{*}{ Colonial } & Goliad ware & & 1 & 2 & 3 \\
\hline & Majolicas & 5 & & & 5 \\
\hline & Lead-glazed & 3 & 1 & 3 & 7 \\
\hline & Lithic artifacts & 4 & & & 4 \\
\hline 18th/19th Century & Galera lead-glazed & 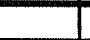 & $\overline{1}$ & & 1 \\
\hline \multirow{3}{*}{ 19th Century } & White earthenwares & 4 & 7 & 2 & $\overline{13}$ \\
\hline & Cut nails & & & 1 & 1 \\
\hline & Slate & 1 & & & 1 \\
\hline \multirow{2}{*}{$\begin{array}{l}\text { Late } 19 \text { th/Early } 20 \text { th } \\
\text { Century }\end{array}$} & Milk bottles & 1 & 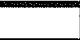 & & 1 \\
\hline & Ceramic button & & 1 & & 1 \\
\hline \multirow{2}{*}{ 20th Century } & Bright green glass & & 1 & & 1 \\
\hline & Cobalt blue glass & 1 & & & 1 \\
\hline \multirow{10}{*}{ Not Datable } & Organics: Bone & 11 & 1 & 5 & 17 \\
\hline & Organics: Mussel shell & 1 & & & 1 \\
\hline & Activities & & 1 & & 1 \\
\hline & Bam/Workshop & & & 1 & 1 \\
\hline & Construction & 2 & 24 & & 26 \\
\hline & Kitchen/Household & 14 & 13 & 1 & 28 \\
\hline & \begin{tabular}{|l|} 
Personal \\
\end{tabular} & 1 & 1 & & 2 \\
\hline & Metal scrap & 3 & 19 & 3 & 25 \\
\hline & Misc. & 1 & 1 & & 2 \\
\hline & Totals & 52 & 72 & 18 & 142 \\
\hline
\end{tabular}

distinguish the lower from the upper stratum. Level 4 (28$38 \mathrm{cmbs}$ ) was comprised of the lower dark gray clay loam and was void of artifacts. TU 7 was terminated at $38 \mathrm{cmbs}$.

\section{Test Unit $8(50-x-50-\mathrm{cm})$}

TU 8 was located $6 \mathrm{~m}$ west of the mission compound wall (see Figure 4-2). TU 8 was one of the 14 units set up to initially test the project area. With the exception of the upper $5 \mathrm{~cm}$ of this unit consisting of small pebbles and organic matter, the soil was comprised of a homogenous gray (10YR $5 / 1$ ) loam extending from 5 to $50 \mathrm{cmbs}$, where the unit was terminated. Pebbles, charcoal, roots, and small sandstone fragments were found to a depth of $40 \mathrm{cmbs}$. The density of artifacts recovered from TU 8 was low compared to many of the units in the Hike-and-Bike Trail area (Table 5-14). The artifact assemblage also shows that this area has been disturbed to a depth of $40 \mathrm{cmbs}$. Artifacts include Goliad ware, lead-glazed, European porcelain, and whiteware ceramics, glass fragments, bone, wire nails, and window glass. A lighter colored material, possibly the remnants of decomposed mortar, appeared in patches across the unit at about $30 \mathrm{cmbs}$ and extended to about $32 \mathrm{cmbs}$. No artifacts were recovered from Level 5 (40-50 cmbs).

\section{Test Unit 9 (50-x-50-cm)}

TU 9 was located in the northern half of the Hike-and-Bike Trail, approximately $3 \mathrm{~m}$ west of the mission compound wall (see Figure 4-2). From the ground surface to $28 \mathrm{cmbs}$, the soil was comprised of a gray (10YR 5/1) loam which contained roots, charcoal flecks, and small pebbles. This soil was present in Levels $1-3$. Level $1(0-8 \mathrm{cmbs})$ contained several brick and rock fragments, and a mix of eighteenththrough twentieth-century materials including wire and cut nails, lithics, bone, and window glass (Table 5-15). The artifact assemblage recovered from Level $2(8-18 \mathrm{cmbs})$ showed the same mix of eighteenth- through twentiethcentury materials including one Goliad ware sherd, two stoneware sherds, wire and cut nails, olive glass, window glass, and plastic; indicating that Level 2 was disturbed. Artifacts collected from Level $3(18-28 \mathrm{cmbs})$ were a mix of eighteenth- through twentieth-century materials as well (Table 5-15). From 28 to $38 \mathrm{cmbs}$, the soil was a dark gray (10YR 4/1) clay loam; this soil was present in Level 4 (28$38 \mathrm{cmbs}$ ). No cultural material was recovered from Level 4 and TU 9 was terminated at $38 \mathrm{cmbs}$. 
Table 5-14. Artifacts Recovered from TU 8

\begin{tabular}{|c|c|c|c|c|c|}
\hline Approximate Dates & Artifact Type & Lv. 1 & Lv. 3 & Lv. 4 & Totals \\
\hline \multirow{3}{*}{ Colonial } & Goliad ware & & 1 & & \\
\hline & Lead-glazed & 1 & 1 & & 2 \\
\hline & Lithic artifacts & 1 & & & \\
\hline \multirow{2}{*}{ 19th Century } & White earthenwares & & & 2 & \\
\hline & Cut nails & & 3 & & \\
\hline Late 19th/Early 20th Century & Porcelain doll dish & & 1 & & \\
\hline \multirow{2}{*}{ 20th Century } & Clear glass (selenium) & & 1 & 1 & 2 \\
\hline & Wire nails & 1 & & & \\
\hline \multirow{5}{*}{ Not Datable } & Organics: Bone & 5 & 3 & 3 & 11 \\
\hline & Arms & & 1 & & \\
\hline & Construction & & 13 & & 13 \\
\hline & Kitchen/Household & 1 & 1 & & 2 \\
\hline & Metal scrap & & 7 & 1 & 8 \\
\hline & Totals & 9 & 32 & 7 & 48 \\
\hline
\end{tabular}

Table 5-15. Artifacts Recovered from TU 9

\begin{tabular}{|c|c|c|c|c|c|}
\hline Approximate Dates & Artifact Type & Lv. 1 & Lv. 2 & Lv. 3 & Totals \\
\hline \multirow{3}{*}{ Colonial } & Goliad ware & & 1 & 1 & 2 \\
\hline & Lead-glazed & & & 1 & 1 \\
\hline & Lithic artifacts & 1 & 1 & & 2 \\
\hline \multirow{2}{*}{ 18th/19th Century } & Olive glass & & 1 & & 1 \\
\hline & Lamp chimney glass & & 2 & 2 & 4 \\
\hline 19th Century & Cut nails & 1 & 3 & 2 & 6 \\
\hline \multirow{2}{*}{$\begin{array}{c}\text { Late } 19 \text { th/Early } 20 \text { th } \\
\text { Century }\end{array}$} & Stonewares & & 2 & & 2 \\
\hline & Clear glass (manganese) & & 1 & 2 & 3 \\
\hline \multirow{4}{*}{ 20th Century } & Clear glass (selenium) & & 6 & 11 & 17 \\
\hline & Bright green glass & & 1 & & 1 \\
\hline & Cobalt blue glass & 1 & & & 1 \\
\hline & Wire nails & 2 & 1 & 3 & 6 \\
\hline \multirow{7}{*}{ Not Datable } & Organics: Bone & 1 & 16 & 6 & 23 \\
\hline & Organics: Mussel shell & & 2 & 2 & 4 \\
\hline & Activities & & & 1 & 1 \\
\hline & Construction & & 4 & 2 & 6 \\
\hline & Kitchen/Household & 4 & 18 & 9 & 31 \\
\hline & Metal scrap & 1 & & 15 & 16 \\
\hline & Misc. & 1 & & 1 & 2 \\
\hline & Totals & 12 & 59 & 58 & 129 \\
\hline
\end{tabular}




\section{Test Units 10 (50-x-50-cm) and $20(1-x-1-\mathrm{m})$}

TUs 10 and 20 were located in the northern half of the Hikeand-Bike Trail, approximately 5 to $6 \mathrm{~m}$ west of the mission compound wall (see Figure 4-2). Initial testing of the Hikeand-Bike Trail showed that TU 10 contained an intact Colonial deposit; therefore, TU 20 was placed adjacent and southeast of TU 10 to further test the integrity of this deposit and to provide broader sampling of the Hike-and-Bike Trail area. The soil color and texture in both units remained basically unchanged from the ground surface to the base of the units. In TU 10, the soil was a homogenous gray (10YR $5 / 1$ ) loam from the ground surface to a depth of $48 \mathrm{cmbs}$. In TU 20, the upper $10 \mathrm{~cm}$ of soil was a dark grayish brown (10YR 4/2) loam and from $10-47 \mathrm{cmbs}$, the soil was comprised of a very dark grayish brown (10YR 3/2) loam.
In both units, Levels 1 and 2 showed evidence of disturbance by the presence of post-Colonial materials. In addition to the presence of charcoal, small roots, and pebbles, Level 1 $(0-8 \mathrm{cmbs})$ contained, among other artifacts, Colonial and post-Colonial ceramics, window glass, lithics, and plastic (Table 5-16). Many artifact types were recovered from Level 2 (8-18 cmbs) including Colonial and post-Colonial ceramics and olive glass fragments. Ceramics consisted of Goliad ware, burnished, lead- and tin-glazed, and whiteware sherds. Four trade beads were recovered from TU 20, Level 2.

In Level 3 of TUs 10 (18-28 cmbs) and 20 (17-27 cmbs), the artifact assemblage is restricted to the Colonial period. Bone and four Goliad ware sherds were recovered from TU 10; and Goliad ware, sandy paste and Galera lead-glazed

Table 5-16. Artifact Recovered from TUs 10 and 20

\begin{tabular}{|c|c|c|c|c|c|c|c|}
\hline Approximate Dates & Artifact Type & Lv. 1 & Lv. 2 & Lv. 3 & Lv. 4 & Lv. 5 & Totals \\
\hline \multirow{6}{*}{ Colonial } & Goliad ware & 8 & 49 & 40 & 2 & & 99 \\
\hline & Other unglazed & & 2 & 1 & & & 3 \\
\hline & Majolicas & 2 & 10 & 3 & & & 15 \\
\hline & Lead-glazed & 17 & 10 & 1 & 1 & & 29 \\
\hline & Trade beads \& jewelry & & 4 & 1 & & & 5 \\
\hline & Lithic artifacts & 7 & 9 & 15 & & & 31 \\
\hline \multirow{2}{*}{ 18th/19th Century } & Olive glass & 1 & 3 & & & & 4] \\
\hline & Galera lead-glazed & 1 & & 3 & & & 4 \\
\hline \multirow{4}{*}{ 19th Century } & White earthenwares & 27 & 19 & & & & 46. \\
\hline & Bottle molded w/ applied lip & 2 & & & & & 2 \\
\hline & Cut nails & 3 & & & & & 3 \\
\hline & Slate & 3 & & & & & 3 \\
\hline \multirow{2}{*}{ Late 19 th/20th Century } & Tea leaf ironstone & 2 & & & & & 2 \\
\hline & Stonewares & 1 & & & & & 1 \\
\hline \multirow{2}{*}{ 20th Century } & Wire nails & 5 & & & & & -1 \\
\hline & Toy metal car & 1 & & & & & 1 \\
\hline \multirow{9}{*}{ Not Datable } & Organics: Bone & 140 & 1029 & 36 & 12 & & 1,217 \\
\hline & Organics: Mussel shell & 4 & 15 & 2. & & & 21 \\
\hline & Barn/Workshop & 1 & & & & & 1 \\
\hline & Construction & 17 & 6 & 1 & & 1 & 25 \\
\hline & Kitchen/Household & 39 & 1 & 1 & & 2 & 43 \\
\hline & Lithics (FCR) & 2 & & 1 & & & 3 \\
\hline & \begin{tabular}{|l} 
Personal \\
\end{tabular} & & 1 & & & & 1 \\
\hline & Metal scrap & 9 & & & & & 9 \\
\hline & Misc. & 2 & 1 & & 1 & & 4 \\
\hline & Totals & 294 & 1,159 & 105 & 16 & 3 & 1,577 \\
\hline
\end{tabular}


and tin-glazed ceramics, bone, shell, lithics, and one trade bead were collected from TU 20. Like Leve13, the artifacts recovered from Level 4 of TUs $10(28-38 \mathrm{cmbs})$ and 20 (27-37 cmbs) are Colonial in age; however, artifact density dramatically decreased in Level 4 (Table 5-16). Only three artifacts were recovered from Level $5(38-48 \mathrm{cmbs}$ in TU 10 and $37-47 \mathrm{cmbs}$ in TU 20) and excavation of these two units was terminated at the base of Level 5. In TU 20, Level 5 was restricted to a $50-x-50-\mathrm{cm}$ area in the southeast quad of the unit.

\section{Test Unit $23(I-x-I-m)$}

TU 23 was approximately $1.5 \mathrm{~m}$ west of the mission compound wall (see Figure 4-2). The presence of twentiethcentury artifacts from the ground surface through Level 6 (0-60 cmbs) indicates that this area has been deeply disturbed (Table 5-17). From the ground surface to $20 \mathrm{cmbs}$, the soil was a gray (10YR 5/1) loam. This soil was present in Levels $1(0-10 \mathrm{cmbs})$ and $2(10-20 \mathrm{cmbs})$. In addition to eighteenth- through twentieth-century artifacts, charcoal and

Table 5-17. Artifacts Recovered from TU 23

\begin{tabular}{|c|c|c|c|c|c|c|c|c|}
\hline Approximate Dates & Artifact Type & Lv. 1 & Lv. 2 & Lv. 3 & Lv. 4 & Lv. 5 & Lv. 6 & Totals \\
\hline \multirow{6}{*}{ Colonial } & Goliad ware & 11 & 39 & 53 & 12 & 1 & 1 & 117 \\
\hline & Other unglazed & 4 & 2 & 2 & 1 & & & 9 \\
\hline & Majolicas & 4 & 3 & 2 & & & 1 & 10 \\
\hline & Lead-glazed & & 1 & 2 & & & & 3 \\
\hline & Trade beads \& jewelry & & 2 & & & & & 2 \\
\hline & Lithic artifacts & 14 & 13 & 3 & 1 & 5 & 3 & 39 \\
\hline \multirow{3}{*}{ 18th/19th Century } & Olive glass & 11 & & & & & & 1 \\
\hline & Galera lead-glazed & 1 & 2 & & & & & 3 \\
\hline & Lamp chimney glass & & & 1 & & & & 1 \\
\hline \multirow{4}{*}{ 19th Century } & White earthenwares & & & & 2 & 2 & 155 & 159 \\
\hline & Yellow ware & & 1 & & & & & 1 \\
\hline & "Black" glass & 2 & & & & & & 2 \\
\hline & Cut nails & & 3 & & & & & 3 \\
\hline \multirow{4}{*}{$\begin{array}{l}\text { Late } 19 \text { th/Early } 20 \text { th } \\
\text { Century }\end{array}$} & Old electrical items & & & 1 & & & & 1 \\
\hline & Band and line whiteware & & 1 & & & & & \\
\hline & .22 caliber short casing & 1 & & & & & & 1 \\
\hline & Clay pipe & & 1 & & & & & 1 \\
\hline \multirow{5}{*}{ 20th Century } & Clear glass (selenium) & & & 1 & & 1 & & 2 \\
\hline & Bright green glass & 1 & & & & & & 1 \\
\hline & Cobalt blue glass & 2 & 2 & & & & & 4 \\
\hline & Machine made glass & 1 & & & 1 & 1 & & 3 \\
\hline & Wire nails & 1 & 2 & 12 & 1 & 3 & 7 & 26 \\
\hline \multirow{9}{*}{ Not Datable } & Organics: Bone & 25 & 230 & 133 & 23 & 26 & 1 & 438 \\
\hline & Organics: Mussel shell & & 1 & 8 & & 1 & & 10 \\
\hline & Activities & & & 2 & & & & 2 \\
\hline & Barn/Workshop & & & & & 9 & & 9 \\
\hline & Construction & 7 & 28 & 2 & 3 & 1 & 2 & 43 \\
\hline & Kitchen/Household & 17 & 22 & 6 & 2 & 2 & 1 & 50 \\
\hline & Lithics (FCR) & & 3 & & & $1)$ & & 4 \\
\hline & Metal scrap & 5 & 97 & 80 & 4 & 21 & 40 & 247 \\
\hline & Misc. & 1 & 6 & 2 & & 1 & & 10 \\
\hline & Totals & 98 & 459 & 310 & 50 & 75 & 211 & 1,202 \\
\hline
\end{tabular}


fragments of mortar were observed throughout Levels 1 and 2 (Table 5-17). Five large (10-20 cm in length) limestone and sandstone rocks, exhibiting no apparent pattern, were present in Level 2. Two trade beads and a nineteenth-century pipe fragment along with eighteenth- and nineteenth-century ceramic sherds were recovered. The soil color changed at $20 \mathrm{cmbs}$ to a dark gray (10YR 4/1) loam which extends to a depth of $36 \mathrm{cmbs}$. Levels 3 and 4 (20-40 cmbs) were primarily within the dark gray loam. Eighteenth- through twentieth-century artifacts, small roots, gravels, and fragments of sandstone were observed in Levels 3 and 4. In Level $3(20-30 \mathrm{cmbs})$ a concentration of gravels was present in the northwest and southwest quadrants of the unit, and the greatest concentration of sandstone fragments came from the northeast and southwest corners. In the southeast quadrant of the unit, the soil contained some charcoal making it darker in color. Artifacts recovered from within the darker soil include glass and metal fragments, wire nails, bone, and ceramics. While the darker soil in the southeast comer of the unit was recognizable, the boundary was diffuse, and no clear outline was visible. The dark soil and artifacts continued through Leve1 4. A post hole (Feature 4, discussed below) was first observed in the west wall of TU 23 at approximately $40 \mathrm{cmbs}$. Between 36 and $60 \mathrm{cmbs}$, the soil was a very dark grayish brown (10YR 3/2) loam. This soil was largely present in Levels 5 and 6 (40-60 cmbs). A mix of eighteenth- through twentieth-century artifacts was recovered from Levels 5 and 6 . The darker area in the southeast comer of the unit continued through Levels 5 and 6, and a Dixie Brand soda water bottle (circa 1920) was exposed at $60 \mathrm{cmbs}$. With the exception of determining the depth of the post hole $(68 \mathrm{cmbs})$, the remainder of the unit was terminated at the bottom of Level $6(60 \mathrm{cmbs})$.

\section{Feature 4}

A post hole was first observed at the bottom of Level 4 (40 $\mathrm{cmbs}$ ) in the west wall of TU 23. This feature extended to a depth of $68 \mathrm{cmbs}$. The post hole was approximately $20 \mathrm{~cm}$ in width, narrowing to about $12 \mathrm{~cm}$ at the base. It was largely comprised of a pale brown matrix (10YR 6/3) with an upper central area of gray soil. The pale brown matrix was the supporting matrix for the post, and the gray central area was comprised of the decomposed post and surrounding soil. Adjacent to the post hole and extending east, was an ashy charcoal matrix containing a few burned sandstone fragments. This ashy charcoal matrix became clearly defined at $43 \mathrm{cmbs}$ and was approximately $5-7 \mathrm{~cm}$ thick. The ashy deposit containing the burned sandstone fragments was likely part of the larger disturbance in this unit (in the southeast corner of TU 23, a circa 1920s bottle was recovered at a depth of $60 \mathrm{cmbs})$. It appears that the hole for the post was dug through the ashy deposit. Given that small remnants of cedar wood from the post were still present in the west wall directly above the feature, the post hole could be relatively recent.

\section{Test Unit $11(50-x-50-\mathrm{cm})$}

TU 11 was located approximately $3.5 \mathrm{~m}$ west of the mission compound wall (see Figure 4-2). From the ground surface to $10 \mathrm{cmbs}$, the soil was comprised of a gray $(10 \mathrm{YR} 5 / 1)$ loam. This soil was present in Level $1(0-8 \mathrm{cmbs})$. Charcoal, roots, and small to medium-sized limestone and sandstone rocks were present throughout this level; and charcoal and some burned bone were observed in the southwest quadrant of the unit. Artifacts recovered from Level 1 represent a mix of eighteenth- and nineteenth-century artifacts including Goliad ware, lead-glazed and whiteware ceramics, bone, window glass, and metal (Table 5-18). Between 10 and 25 cmbs, the soil was a dark grayish brown (10YR 4/2) loam containing flecks of charcoal, small roots, and sandstone fragments. Levels $2(8-18 \mathrm{cmbs})$ and $3(18-28 \mathrm{cmbs})$ were largely comprised of this soil. With the exception of a single piece of window glass, the remaining artifacts recovered from Level 2 are Colonial in age. They include Goliad ware, sandy paste lead-glazed, and one San Agustin tin-glazed ceramics, bone, one brick/tile fragment, and lithics. Similarly, artifacts recovered from Level $3(18-28 \mathrm{cmbs})$ are Colonial in age. Goliad ware and bone were the only two artifact types present within this level. From 25-38 cmbs, the soil consisted of a dark gray (10YR 4/1) clay loam with some mottling of a dark brown (10YR 3/3) clay loam. Level 4 (28-38 cmbs) was largely comprised of this soil. Roots and small pebbles were observed throughout the level; however, Level 4 was void of cultural material and TU 11 was terminated at 38 cmbs.

\section{Test Units 12, 16 (50-x-50-cm), and $18(1-x-1-m)$}

TUs 12,16 , and 18 were located approximately $5 \mathrm{~m}$ west of the mission compound wall (see Figure 4-2). TU 12 was one of the initial 14 units excavated. When large rocks were encountered in Level 2, they were designated Feature 1 and TU 16 was placed adjacent and to the east of TU 12 . The same feature was encountered in Level 2 of TU 16, so TU 18 was placed south of TU 12 to further examine this group of rocks. At the time, Feature 2 in TUs 6 and 19 had been noted, and it was considered possible that these features were part of a foundation in line with Feature 2. However, as was the case in TUs 6 and 19, the rocks uncovered proved 
Table 5-18. Artifacts Recovered from TU 11

\begin{tabular}{|c|c|c|c|c|c|}
\hline Approximate Dates & Artifact Type & Lv. 1 & Lv. 2 & Lv. 3 & Totals \\
\hline \multirow{4}{*}{ Colonial } & Goliad ware & 5 & 16 & 9 & 30 \\
\hline & Majolicas & & 1 & & 1 \\
\hline & Lead-glazed & 3 & 1 & & 4 \\
\hline & Lithic artifacts & & 1 & & 1 \\
\hline 18th/19th Century & Galera lead-glazed & 3) & & & 3 \\
\hline 19th Century & White earthenwares & 1 & & & 1 \\
\hline \multirow{5}{*}{ Not Datable } & Organics: Bone & 53 & 92 & 45 & 190 \\
\hline & Organics: Mussel shell & 1 & & & 1 \\
\hline & Construction & 2 & 2 & & 4 \\
\hline & Kitchen/Household & 5 & & & 5 \\
\hline & Metal scrap & 1 & & & 1 \\
\hline & Totals & 74 & 113 & 54 & 241 \\
\hline
\end{tabular}

to be part of a loose pile of limestone and sandstone rubble, mixed with eighteenth- through twentieth-century artifacts.

In TUs 12 and 16, a gray (10YR 5/1) loam extended from the ground surface to $26 \mathrm{cmbs}$ in the eastern part of TU 16 , and to $38 \mathrm{cmbs}$ in the western end of TU 12 . The gray loam contained cultural material and sloped down to the west. The acequia is located approximately $3 \mathrm{~m}$ west of TUs 12 and 16 and may, in part, explain the slope of this deposit. The gray loam was present primarily in Levels $1-3$ of TU 16 and Levels $1-4$ of TU 12. Pebbles and a few cobbles, roots, charcoal, and a mix of eighteenth- through twentiethcentury artifacts were present in Level $1(0-7 \mathrm{cmbs})$. Level 2 (7-17 cmbs) contained roots, charcoal, medium to large limestone and sandstone rocks (Feature 1, discussed below), and historic artifacts (Table 5-19). Cultural material recovered from TU 16, Level 2 is Colonial in age, while Level 2 of TU 12 contained both Colonial-period and nineteenth-century material. In Level 3 (17-27 cmbs) of TU 16, roots, charcoal, bone, lithics, and Colonial artifacts were present. In Level 3 of TU 12, the west half of the unit was dug first in order to cross-section and determine the depth of Feature 1. The artifacts collected from the west half of TU 12, Level 3 consisted of three Colonial ceramic sherds and bone. In the east half of TU 12, Level 3 was inadvertently dug through Level 4 resulting in the mixing of artifacts from these two levels. Therefore, the artifacts recovered from the eastern half of Level 3 and Level 4 of the entire unit have been combined (Table 5-19). The datable cultural material recovered from Level 3/4 (17-37 cmbs) consists entirely of artifacts from the eighteenth and nineteenth centuries. Of the 45 ceramics recovered, only two whiteware sherds post-date the Colonial period. A dense amount of charcoal was observed throughout the gray loam with concentrations noted in the northeast quadrant of TU 12 (Levels 1 and 2), and the southeast quadrant of TU 16 (Level 2).

Directly beneath the gray loam, a dark yellowish brown (10YR 4/4) clay loam extended from $26-48 \mathrm{cmbs}$ in the eastern part of TU 16; and from 38-48 cmbs in the western part of TU 12. The dark yellowish brown loam was present primarily in Levels 4 and 5 of TU 16, and Level 5 (37-47 cmbs) of TU 12. With the exception of one small lithic flake and one bone in TU 12, Level 5 (37-48 cmbs), the very dark grayish brown loam was sterile and void of cultural material. No artifacts were recovered from Levels 4 and 5 of TU 16. Excavation of TUs 12 and 16 was terminated at $47 \mathrm{cmbs}$.

TU 18 was located adjacent to and south of TU 12 (see Figure 4-2). In TU 18 (1-x-1-m), a layer of black (10YR 2/ 1) ashy soil was present in the southwest corner and in the west wall of the unit (Figure 5-19). The ashy deposit was largely concentrated in the southwest comer of TU 18 , becoming more diffuse and lighter in color along the western wall. It was irregular in thickness in the west and south wall profiles, being as thick as $30 \mathrm{~cm}$ in the southwest corner, and as thin as $6 \mathrm{~cm}$ in the west wall profile. Directly beneath the ashy soil, and in the remainder of the unit a dark grayish brown (10YR 4/2) loam extended from the ground surface to a depth of $30 \mathrm{cmbs}$ (Figure 5-19). The ashy soil and the loam were present primarily in Levels $1-3(0-28 \mathrm{cmbs})$ and contained roots and limestone and sandstone rock fragments. 
Table 5-19. Artifacts Recovered from TUs 12, 16, and 18

\begin{tabular}{|c|c|c|c|c|c|c|c|c|c|c|c|c|c|c|c|c|c|}
\hline \multirow[b]{2}{*}{$\begin{array}{l}\text { Approximate } \\
\text { Dates }\end{array}$} & \multirow[b]{2}{*}{ Artifact Type } & \multicolumn{6}{|c|}{ TU 12} & \multicolumn{4}{|c|}{ TU 16} & \multicolumn{5}{|c|}{ TU 18} & \multirow[b]{2}{*}{$\begin{array}{r}\text { Overiall } \\
\text { Totais. }\end{array}$} \\
\hline & & $\ddot{j}$ & 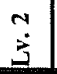 & $\dot{3}$ & $\frac{1}{3}$ & 管 & Totals & $\overline{3}$ & $\stackrel{Y}{\dot{z}}$ & 3 & Totals & $\ddot{3}$ & 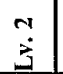 & $\stackrel{m}{3}$ & n & Totals & \\
\hline \multirow{8}{*}{ Colonial } & Goliad ware & 4 & 16 & 2 & 35 & & 57 & 4 & 6 & 11 & 21 & 11 & 52 & 78 & & 141 & 219 \\
\hline & Other unglazed & & & & 1 & & 1 & & & 5 & 5 & & 2 & & & 2 & 8 \\
\hline & Majolicas & 1 & 1 & 1 & 3 & & 6 & 1 & 2 & 2 & 5 & 1 & 16 & 11 & & 28 & 39 \\
\hline & Lead-glazed & & 2 & & 3 & & 5 & 6 & 3 & & 9 & 1 & 4 & 19 & & 24 & . 38 \\
\hline & Piloncillo molds & & & & & & 0 & & & & 0 & & & 1 & & $1]$ & in \\
\hline & Trade beads \& jewelry & & & & & & 0 & 1 & & & 1 & & & & & 0 & ?.r. \\
\hline & Lithic artifacts & & 1 & & 4 & 1 & 6 & 3 & 1 & 3 & 7 & 3 & 3 & 6 & & 12 & 25 \\
\hline & Copper alloy arrow point & & & & & & 0 & & & & 0 & & 1 & & & 1 & 1 \\
\hline \multirow{3}{*}{$\begin{array}{c}18 \text { th } / 19 \text { th } \\
\text { Century }\end{array}$} & Olive glass & & 2 & & & & 2 & & & & 0 & 2 & 5 & & & 7 & 9 \\
\hline & Musket balls & & & & & & 0 & & & & 0 & & & 1 & & 1 & 1 \\
\hline & Galera lead-glazed & 1 & & & 1 & & 2 & & & 1 & 1 & 1 & 2 & 10 & & 13 & 16 \\
\hline \multirow{4}{*}{ 19th Century } & White earthenwares & 2 & 4 & & 2 & & 8 & 4 & & 1 & 5 & 12 & 15 & 5 & & 32 & 45 \\
\hline & Bottle w/pontil mark & & & & & & 0 & & & & 0 & & 1 & 1 & & 2 & 2 \\
\hline & "Black" glass & & & & & & 0 & & & & 0 & 1 & & & & 1 & 2. \\
\hline & Cut nails & & 1 & & & & 1 & & & & 0 & & & & & 0 & 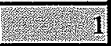 \\
\hline \multirow{3}{*}{$\begin{array}{l}\text { Late 19th/ Early } \\
\text { 20th Century }\end{array}$} & Tea leaf ironstone & & & & & & 0 & & & & 0 & 1 & & & & 1 & 1 \\
\hline & Composition button & & & & & & 0 & & & & 0 & 1 & & & & 1 & 1 \\
\hline & Stonewares & & & & & & 0 & & & & 0 & 2 & & 1 & & 3 & 3 \\
\hline 20th Century & Wire nails & 1 & & & & & 1 & & & & 0 & & & & & 0 & 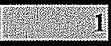 \\
\hline \multirow{9}{*}{ Not Datable } & Organics: Bone & 30 & 85 & 15 & 168 & 1 & 299 & 35 & 32 & 64 & 131 & & 347 & 596 & 3 & 946 & $\begin{array}{r}1,376 \\
\end{array}$ \\
\hline & Organics: Mussel shell & 2 & 2 & & & & 4 & 4 & 2 & & 6 & 5 & 13 & & & 18 & 28 \\
\hline & Barn/Workshop & & & & & & 0 & & & & 0 & 1 & & & & 1 & $\begin{array}{ll}-5: 5 & 1 \\
\end{array}$ \\
\hline & Construction & & 2 & & 3 & & 5 & 3 & & 1 & 4 & 19 & 10 & & & 29 & $\sqrt{38}$ \\
\hline & Kitchen/Household & & & & & & 0 & 3 & & 2 & 5 & 24 & 7 & 6 & & 37 & $\begin{array}{r}\quad 42 \\
\end{array}$ \\
\hline & Lithics (FCR) & & & & 1 & & 1 & & & & 0 & 1 & & & & 1 & $\begin{array}{rr} & 2 \\
\end{array}$ \\
\hline & Personal & 1 & & & & & 1 & & & & 0 & & & & & 0 & 1 \\
\hline & Metal scrap & & & & & & 0 & & & & 0 & 2 & & & & 2 & $\begin{array}{rl} & \\
2 & 2\end{array}$ \\
\hline & Misc. & & & & 2 & & 2 & & 1 & & 1 & 21 & 29 & & & 50 & 5 \\
\hline & Totals & 42 & 116 & 18 & 223 & 2 & 401 & 64 & 47 & 90 & 201 & 109 & 507 & 735 & 3 & 1,354 & 1,956 \\
\hline
\end{tabular}

* Levels 3 and 4 excavated as a single level in eastern half of TU 12 .

Artifacts recovered from Levels 1 (0-8 cmbs), 2 (8-18 $\mathrm{cmbs}$ ), and $3(18-28 \mathrm{cmbs})$ show a mix of eighteenththrough early-twentieth-century materials including Colonial and post-Colonial ceramics, lithics, glass fragments, bone, and window glass (Table 5-19). A composition button of early-twentieth-century manufacture came from Level 1. Feature 1 (discussed below) was present in Level 2 (8-18 cmbs) of TU 18. Level 2 also contained a metal projectile point (see description in Chapter 6) and a possible flaked piece of hand-blown glass. In Level 3 (18-28 cmbs) there was a lead musket ball. Directly below the dark grayish brown loam was a dark yellowish brown (10YR 4/4) clay loam between approximately 30 and $48 \mathrm{cmbs}$ (Figure $5-19)$. This soil was present in Levels 4 (28-38 cmbs) and 5 (38-48 cmbs). No artifacts were recovered from Level 4 and bone was the only artifact type recovered from Level 5 (38-48 cmbs). TU 18 was terminated at $48 \mathrm{cmbs}$.

\section{Feature 1}

Feature 1 was identified in TUs 12,16 , and 18, and consisted of medium to large-sized limestone and sandstone rocks (10$20 \mathrm{~cm}$ in diameter) with no apparent form or structure. With the exception of a few small rocks uncovered in Level 1, Feature 1 was largely present in Level 2 (7-17 cmbs in TUs 


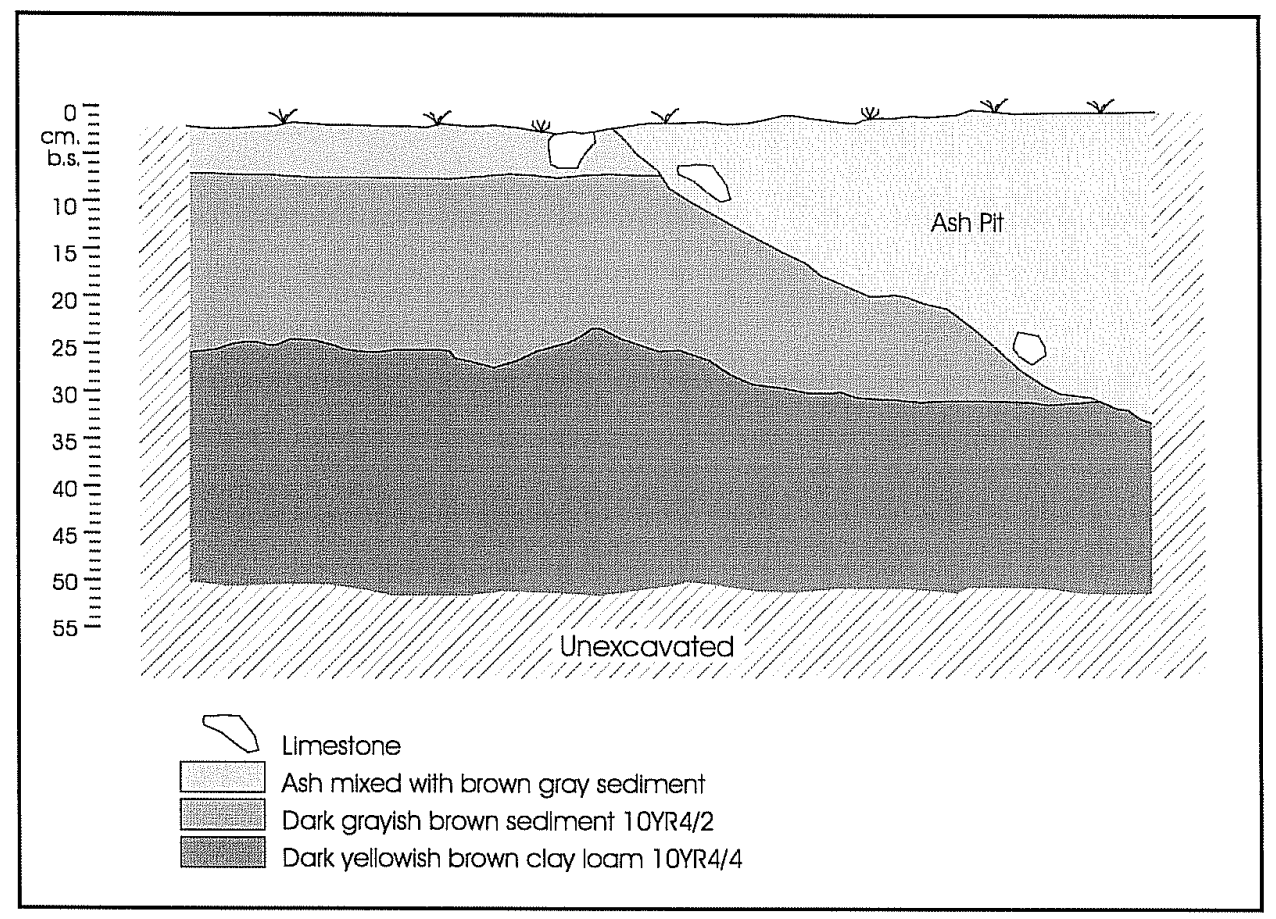

Figure 5-19. Profile of the south wall of TU 18.

12 and 16, and 8-18 cmbs in TU 18) within a gray loam soil containing cultural material. While the rocks uncovered in Level 2 of TUs 16 and 18 constituted a single course or layer, the westernmost extent of the rocks in TU 12 were two layers thick sloping downward to a depth of $30 \mathrm{cmbs}$. While rock was scattered in TU 18 , there was a clustering or concentration of 15 rocks in the northeast quadrant of the unit. Interspersed among the rocks of Feature 1 were roots, pebbles, charcoal, and a mix of eighteenth- through early-twentieth-century artifacts. There was no evidence of mortar on any of the rocks associated with Feature 1, and cultural material was located above, below, and between the rocks. An animal long bone fragment was observed lying in a vertical position between two large rocks in TU 12, Level 2, indicating that Feature 1 may likely represent discarded material from an earlier period of construction at the mission. Feature 1 appeared to extend north of TUs 12 and 16 and east of TUs 16 and 18 .

\section{Test Unit 13 (50-x-50-cm)}

TU 13 was located approximately $3 \mathrm{~m}$ west of the mission wall (see Figure 4-2). From the ground surface to $6 \mathrm{cmbs}$, the soil was comprised of a very compact gray (10YR 5/1) loam containing small pebbles and roots, and some charcoal fragments. Level $1(0-8 \mathrm{cmbs})$ was primarily within this upper soil horizon. Artifacts recovered from Level 1 include eighteenth- and nineteenth-century ceramics, nineteenth- and twentieth-century glass fragments, bone, lithics, and iron scrap (Table 5-20). One large (20-25 cm in length) and four smaller $(5-10 \mathrm{~cm}$ in length) rocks were observed at the bottom of Level 1. The rocks exhibited no recognizable pattern and did not extend below Level 1. At 6-20 cmbs the soil changed slightly in color to a grayish brown (10YR 5/ 2) loam while retaining its hard, compact characteristic noted in Level 1. Level 2 (8-18 cmbs) fell largely within this soil horizon. Small roots and charcoal fragments were observed 
throughout Level 2; and the pebbles noted in Level 1 were no longer present in Level 2. There was a decrease in the number of artifacts recovered from Level 2 compared to Level 1 (Table 5-20). Cultural material is comprised of three ceramics (two Goliad ware and one tin-glazed), glass fragments, and bone. Between 20-42 cmbs, the soil was a dark grayish brown (10YR 4/2) sandy loam. This soil contrasted sharply in texture to the soil commonly seen in the project area. It was present in Levels $3(18-28 \mathrm{cmbs})$ and $4(28-38 \mathrm{cmbs})$ and was soft and easily excavated. A few fragments of charcoal were observed in Level 3, but they did not extend into Level 4. A few sandstone fragments, $10-15 \mathrm{~cm}$ in length and $3 \mathrm{~cm}$ thick, were encountered at approximately $30 \mathrm{cmbs}$. Artifacts continued to decrease in number with only two glass fragments and two pieces of lithic debitage in Level 3; and one Goliad ware sherd in Level 4. Also observed in Level 4 were nodules of a lighter colored soil (10YR 6/4) mottled with the darker soil. Between 42-48 cmbs the soil color remained a dark grayish brown (10YR 4/2) clay loam; however, due to an increase in clay content, the soil texture was not as loose and granular as it was in Levels 3 and 4 . The clay loam was largely present in Level 5 (38-48 cmbs) and the mottling noted in Level 4 extended through Level 5. Two lithics were recovered from Level 5 , and TU 13 was terminated at $48 \mathrm{cmbs}$.

\section{Test Unit 14 (50-x-50-cm)}

TU 14 was the northernmost unit in the area of the Hikeand-Bike Trail (see Figure 4-2). The soil in this unit was a homogenous $10 \mathrm{YR} 5 / 1$ loam and the artifacts recovered indicate disturbance from the ground surface through Level $5(0-50 \mathrm{cmbs})$. The only difference in soil texture occurred in the upper $15 \mathrm{~cm}$ where the soil was more compact and difficult to excavate. Flecks of charcoal, small angular rocks, fragments of mortar and roots occurred throughout the unit. Artifacts recovered from Level $1(0-10 \mathrm{cmbs})$ include glass fragments, bone, and one shell fragment (Table 5-21). Artifact types common to Levels 2-4 (10-40 cmbs) include nineteenth- to twentieth-century glass fragments, wire nails, bone, and whiteware ceramic sherds. With the exception of one piece of Goliad ware in Level 2, there was a conspicuous lack of Colonial ceramics in Levels $1-4(0-40 \mathrm{cmbs})$, and a total absence of lithics in Levels 1-5 of TU 14. While there was a dramatic increase in the number of Colonial ceramics present in Level 5 (15 Goliad ware, two lead-glazed sandy paste, two undecorated tin-glazed, one polychrome tinglazed), there were also 10 sherds of whiteware, three glass fragments, and four metal fragments. TU 14 was terminated at $50 \mathrm{cmbs}$.

Table 5-20. Artifacts Recovered from TU 13

\begin{tabular}{|c|c|c|c|c|c|c|c|}
\hline Approximate Dates & Artifact Type & Lv. 1 & Lv. 2 & Lv. 3 & Lv. 4 & Lv. 5 & Totals \\
\hline \multirow{3}{*}{ Colonial } & Goliad ware & 13 & 2 & & $\overline{1}$ & & 16 \\
\hline & Majolicas & & 1 & & & & 1 \\
\hline & Lithic artifacts & 10 & & 2 & & 2 & 14 \\
\hline \multirow{2}{*}{ 18th/19th Century } & Olive glass & 1 & & & & & 1 \\
\hline & Lamp chimney glass & 1 & & & & & 1 \\
\hline 19th Century & White earthenwares & 7 & & & & & 7 \\
\hline Late 19th/Early 20th Century & Clear glass (manganese) & 1 & & & & & 1 \\
\hline 20th Century & Cobalt blue glass & & 2 & & & & 2 \\
\hline \multirow{6}{*}{ Not Datable } & Organics: Bone & 23 & 35 & & & & 58 \\
\hline & Construction & 1 & & & & & 1 \\
\hline & Kitchen/Household & 5 & 7 & 2 & & & 14 \\
\hline & Lithics (FCR) & & & 1 & & & 1 \\
\hline & Metal scrap & 2 & & & & & 2 \\
\hline & Misc. & 1 & & & & & 1 \\
\hline & Totals & 65 & 47 & 5 & 1 & 2 & 120 \\
\hline
\end{tabular}


Table 5-21. Artifacts Recovered from TU 14

\begin{tabular}{|c|c|c|c|c|c|c|c|}
\hline Approximate Dates & Artifact Type & Lv. 1 & Lv. 2 & Lv. 3 & Lv. 4 & Lv. 5 & Totals \\
\hline \multirow{3}{*}{ Colonial } & Goliad ware & & 1 & & & 15 & 16 \\
\hline & Majolicas & & & & & 3 & 3 \\
\hline & Lead-glazed & & & & & 2 & 2 \\
\hline 18th/19th Century & Olive glass & & 2 & & 2 & & $\overline{4}$ \\
\hline \multirow{4}{*}{ 19th Century } & White earthenwares & & 3 & 2 & 6 & 10 & 21 \\
\hline & "Black" glass & & & & 3 & & 3 \\
\hline & Cut nails & & 1 & & & & 1 \\
\hline & Slate & & 1 & & & & 1 \\
\hline \multirow{3}{*}{$\begin{array}{c}\text { Late } 19 \text { th/Early 20th } \\
\text { Century }\end{array}$} & Tea leaf ironstone & & & & 1 & & 1 \\
\hline & Bitters bottles & & & & 1 & & 1 \\
\hline & Old electrical items & & 1 & & & & 1 \\
\hline \multirow{4}{*}{ 20th Century } & Clear glass (selenium) & & & & 2 & 1 & 3 \\
\hline & Bright green glass & & 1 & & & & 1 \\
\hline & Cobalt blue glass & & & 1 & & & 1 \\
\hline & Wire nails & & 5 & 3 & 2 & & 10 \\
\hline \multirow{5}{*}{ Not Datable } & Organics: Bone & 1 & 5 & 2 & 6 & 50 & 64 \\
\hline & Organics: Mussel shell & 1 & & 1 & & & 2 \\
\hline & Construction & 5 & & 7 & 6 & 1 & 19 \\
\hline & Kitchen/Household & 2 & 14 & 5 & 14 & 1 & 36 \\
\hline & Metal scrap & & & & 18 & 5 & 23 \\
\hline & Totals & 9 & 34 & 21 & 61 & 88 & 213 \\
\hline
\end{tabular}




\section{Chapter 6: Artifacts}

A total of 32,740 artifacts was recovered during this project. A brief discussion of each artifact class follows, with emphasis on those items that are temporally diagnostic or otherwise of interest. The artifacts in this collection were divided into classes as described in Table 4-1. A complete, provenienced artifact catalog is available from CAR by request in either digital or paper format.

\section{Kitchen/Household}

This class includes artifacts associated with the household, including ceramics, glass, tableware, etc. A total of 6,434 items from this class was recovered, the majority of which $(79 \%, n=5,086)$ are ceramics.

\section{CERAMICS}

Ceramics are particularly useful artifacts for dating archeological sites and the deposits within them, since the types and decoration varied through time. This is especially true on Spanish mission sites that were occupied from the early eighteenth through the early twentieth centuries, during which time ceramic fabrics also underwent readily observable changes. In addition, the ceramics used on the Texas frontier varied considerably depending upon the country in which they were made. However, the comparatively small size of the ceramic sherds recovered during this project makes identification beyond the most general categories very difficult. The following is a discussion of the types of ceramics recovered during this project. Figures 6-1, 6-2, and 6-4 through 6-8 show selected examples of the types of ceramics recovered.

\section{Unglazed Wares}

\section{Goliad Plain Ware}

The Indians who came to the missions on the San Antonio River brought with them the skill of making pottery. Apparently, they continued to make simple bowls and jars using the clay found in the vicinity. The first Spanish site where this type was isolated and described was Mission Espiritu Santo in Goliad (Mounger 1959:163). Maria Mounger, in her report on the archeological excavations at Mission Espiritu Santo, called these Indian-made ceramics Goliad Plain (Mounger 1959:163), and the name continues to be used today. By far the predominant ceramic type on Spanish Colonial mission sites in South Texas, these vessels seem to have been used by everyone at the site, as they are found both in and around all the structures as well as in the trash deposits.

Sherds of Goliad Plain vary in color from black through dark gray to red, sometimes all on the same vessel. This is because they were fired over open fires rather than in the high, even heat of a pottery kiln. This pottery type can be recognized by the presence of small white or gray-white inclusions of bone. Sherds can vary from $2 \mathrm{~mm}$ to $20 \mathrm{~mm}$ in thickness, and are usually very small. A total of 2,468 sherds of Goliad Plain ware was recovered during this project. Figure 6-1a shows an example of this type of ware.

\section{Piloncillo Molds}

Sugar cane was raised in many of the San Antonio missions. It was processed in a sugar mill, where the cane was crushed in order to extract the juice. This was then caramelized in a vat or cauldron and poured into ceramic molds (Clark 1976:247) to produce piloncillo (brown sugar bars) to be distributed to the Indians. The molds, wheel-turned and unglazed, were evidently imported from Mexico since no evidence has been found for potters' wheels at the missions (Figure 6-1b).

A nearly whole piloncillo mold was collected during the CWA reconstruction at Mission San José in 1933 (Schuetz 1970:Addendum Figure 8E). Two fragments of a mold were recovered by Schuetz during the installation of a sprinkler system at San José in 1968 (Schuetz 1970:17). The five sherds recovered during this project are identified as piloncillo mold fragments by their curvature $(8 \mathrm{~mm}$ diameter), their body thickness (10-12 $\mathrm{mm})$, and their apparent wheel turning.

\section{Valero}

Pinkish tan to tan sherds of large wheel-made vessels often decorated with red-brown painted designs (Figure 6-1c) have been recovered from most Colonial sites in South Texas. This type has been tentatively dated ca. 1730 to 1760 (Ivey and Fox 1999:37). Most of the Valero ware sherds in this collection $(n=80)$ do not bear red paint, but the uniformly 


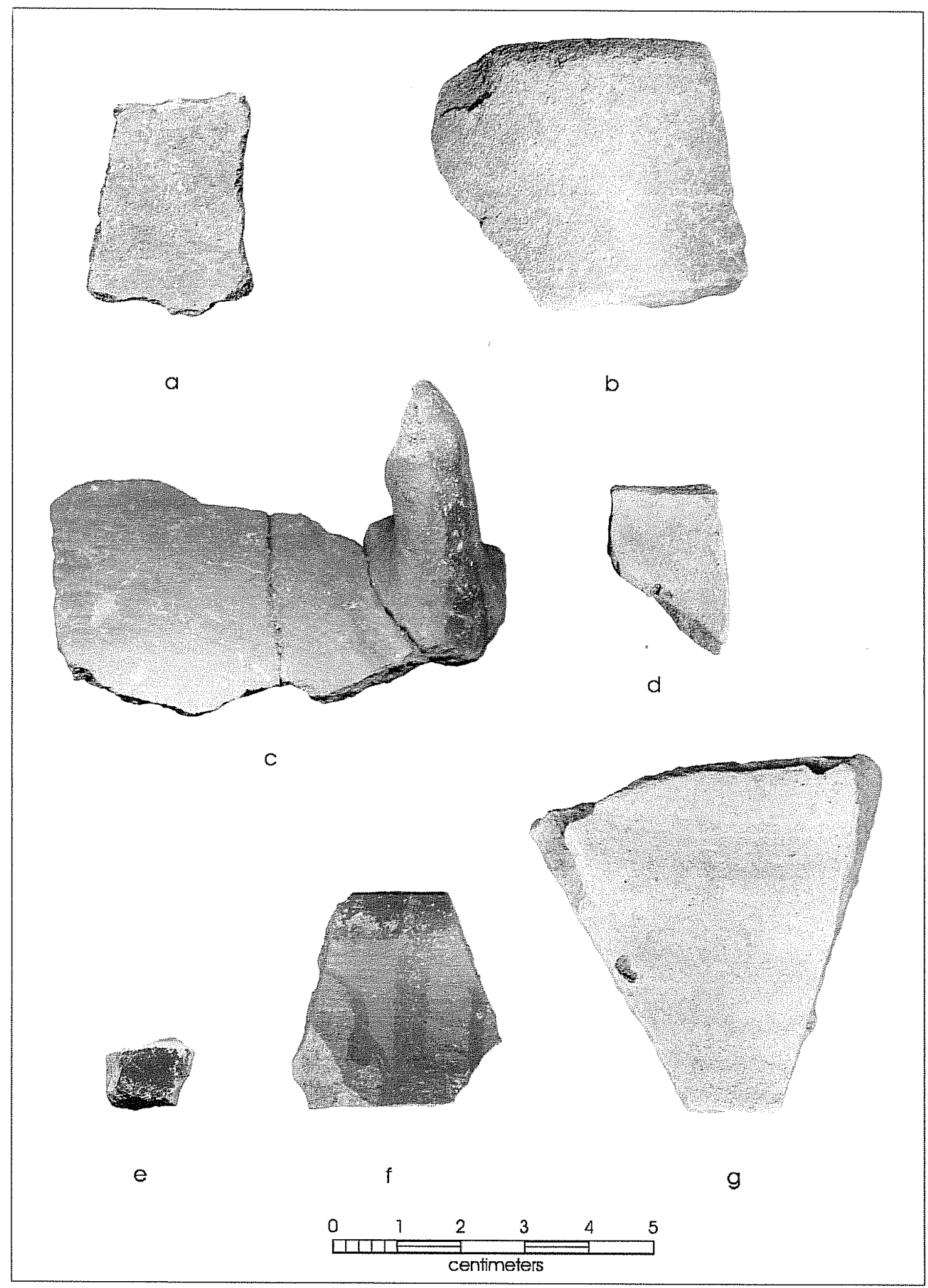

Figure 6-1. Selected unglazed Colonial ceramic sherds: a) Goliad Plain sherd; b) Piloncillomold; c) Valero ware with red paint on handle fragment; d) unidentified Colonial unglazed brown ware; e) Tonalá Bumished ware; f) Red Burnished ware, showing burnished pattern on exterior; g) Olive jar. 
reddish yellow paste with no bone temper and the large curvature of the sherds confirm the type.

At the bottom of the kiln (TU 32, Level 8), three sherds recovered mend to form a section of a large, bulbous Valero water jar with red painted designs (Figure 6-2). It is similar to the tiny Valero ware sherds found in other excavations of eighteenth-century sites (Fox et al. 1976:67; Ivey and Fox 1981:31), and has the same type of red paint as seen in Figure 6-1c.

\section{Unidentified Unglazed Type}

There are five thin sherds ( 3 to $5 \mathrm{~mm}$ thick) of plain brown ware that do not appear to be wheel-made, and do not resemble any type previously identified at local Colonial sites (see Figure 6-1d for an example). They do not resemble the sherds that were apparently made in the kiln. Their age is unknown, but they are not highly refined earthenwares, and are, therefore, probably Colonial or early-nineteenthcentury in origin.

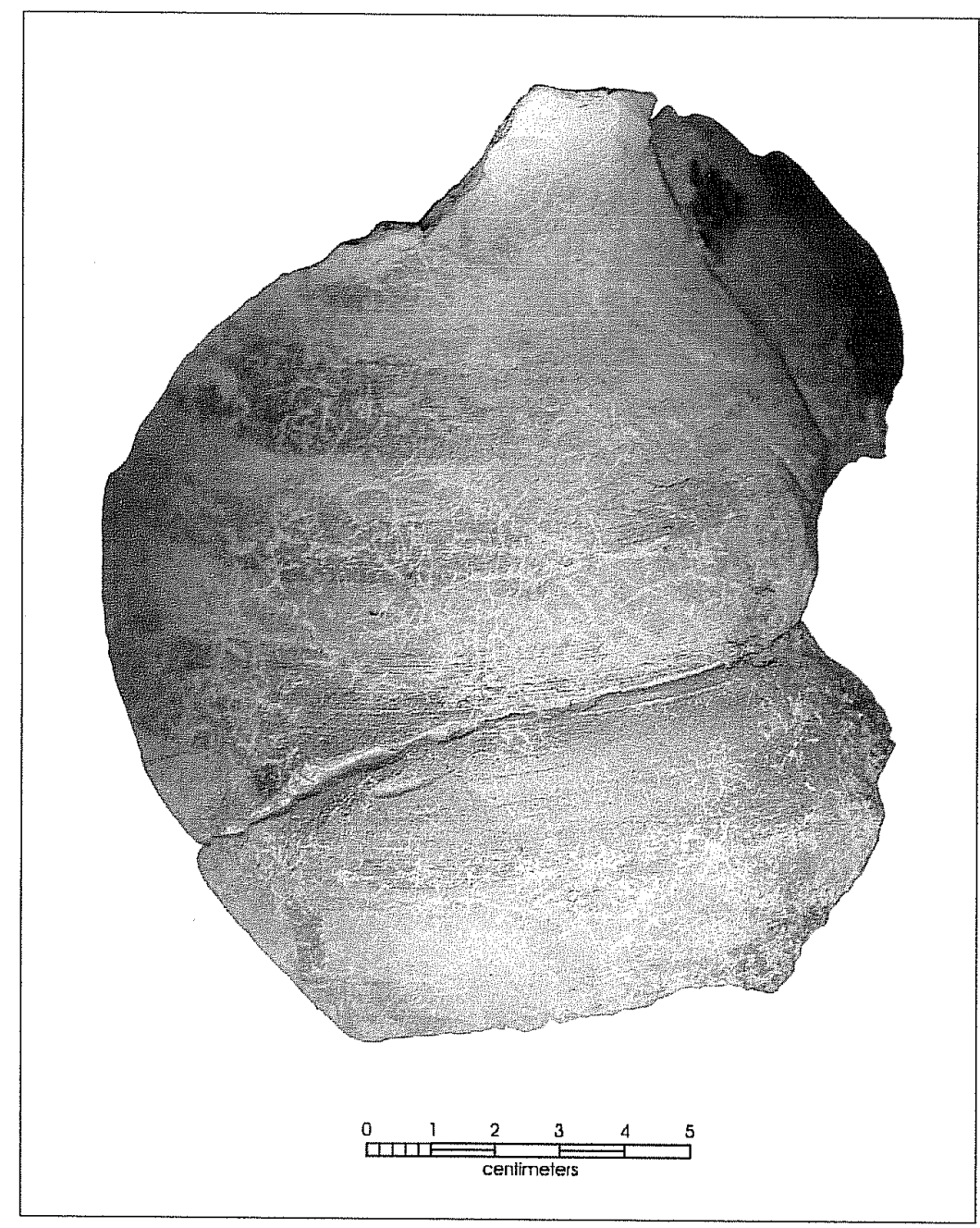

Figure 6-2. Fragment of a Valero ware water jug found in kiln. 


\section{Tonalá Burnished Ware}

A burnished ware made in the town of Tonalá, Jalisco, has a fine gray paste that has a sweet, earthy fragrance when damp. Vessel walls are generally thin (ca. 4-6 mm) and are burnished on one or both surfaces. The eight sherds in this collection are very small, and all but one bear a burnished red-brown slip on one surface (Figure 6-1e). This type was imported to Colonial sites throughout the eighteenth century.

\section{Red Burnished Ware}

Sherds of this ware have been recovered from eighteenthcentury Colonial sites throughout Texas. They have a highly burnished red slip on a fine-grained red body. The exteriors of vessels have burnished designs on matte areas, and the burnished areas tend to spall during firing, giving a speckled appearance on some sherds. The 19 sherds recovered during this project are too small to allow identification of vessel shape. Two rim sherds are present in the collection. The sherd shown in Figure 6-1f has a pattern in burnished (appears darker) and matte areas on the outer surface.

\section{Olive Jar}

Sherds of ceramic jars used for shipping wine and olive oil from Spain occasionally turn up in eighteenth-century sites in Texas. The two olive jar sherds recovered represent an unglazed jar with throwing rings on the interior. The coarse, reddish tan body and the thickness of the wall (14-15 mm) positively identify this type (Figure 6-1g).

\section{Unglazed Kiln-made Wares}

Included in the fill from the kiln were 960 sherds of unglazed, wheel-turned pottery which appear to be from the waster pile (discards of broken or mis-fired vessels) that would have accumulated outside the kiln during the time it was in use. These provide a sample of the shapes and sizes of the vessels that were being fired in the kiln (Figure 6-3). The fact that they are all unglazed suggests that those that were considered acceptable would have been taken somewhere else to be glazed and fired again at a higher temperature, if indeed they were to be glazed. Glazed ware requires a preliminary firing at rather low temperatures and then a shorter firing at higher temperatures after a liquid glaze is applied (Foster 1955:11).

The vessels appear be primarily shallow bowls (Figure $6-4 a)$ of various sizes, ranging from $15 \mathrm{~cm}(6 \mathrm{in}$.) to $29 \mathrm{~cm}$ (11.5 in.) in diameter, but others appear to be larger containers.
The paste varies in thickness from 4-13 mm. None had a ring foot, but instead had a flattened area on the base to steady them on a flat surface (Figure 6-4b). Two sherds from one vessel represent a jar with a $12-\mathrm{cm}$ mouth, the only such vessel present in the collection. The sherds range in color from light reddish brown (5YR 6/4) to dark gray (10YR 4/1). No sherds of this pottery, glazed or unglazed, have been recovered in other excavations at Mission Espada, or indeed elsewhere in the San Antonio area.

\section{Lead-Glazed Wares}

\section{Sandy Paste Lead-Glazed}

Lead-glazed vessels with a sandy paste were the most common utility ware brought to the frontier from Mexico, and the most common imported type recovered during this project $(n=416)$. They vary from a heavy (10 mm thick) yellow-glazed ware (Figure 6-5a) to a slightly thinner (3-5 $\mathrm{mm}$ ) ware with a yellow body and green rim band.

\section{Galera Ware}

Sherds of thin (3-4 mm) lead-glazed ware with a finetextured orange paste are commonly recovered from Colonial sites in Texas and elsewhere in the southwest. It is still being made today in western Mexico, but was most popular in the eighteenth and nineteenth centuries. The thin lead glaze on these vessels brings out the red-orange color of the paste. Chocolate pots and bean pots are usually decorated with cream, brown, and green designs (Figure $6-5 b)$. One hundred sherds of this type were recovered.

\section{Red-Brown Ware}

Vessels with a similar paste to Galera ware but bearing a smooth red-brown glaze on the interior surface sometimes are decorated with a single dark brown band. The sherds recovered from this site $(n=6)$ are too small to allow reconstruction of vessel shape (Figure 6-5c).

\section{Black Luster}

Sherds with a shiny black glaze over a buff paste appear to represent small pots of some type. Schuetz (1969:52) has identified black luster sherds with a buff paste as coming from Santa Fe, Michoacán. Barnes (1980:100) describes black lusterware with a reddish brown paste still being made in Michoacán. Six fragments of this type were recovered (Figure 6-5d) 


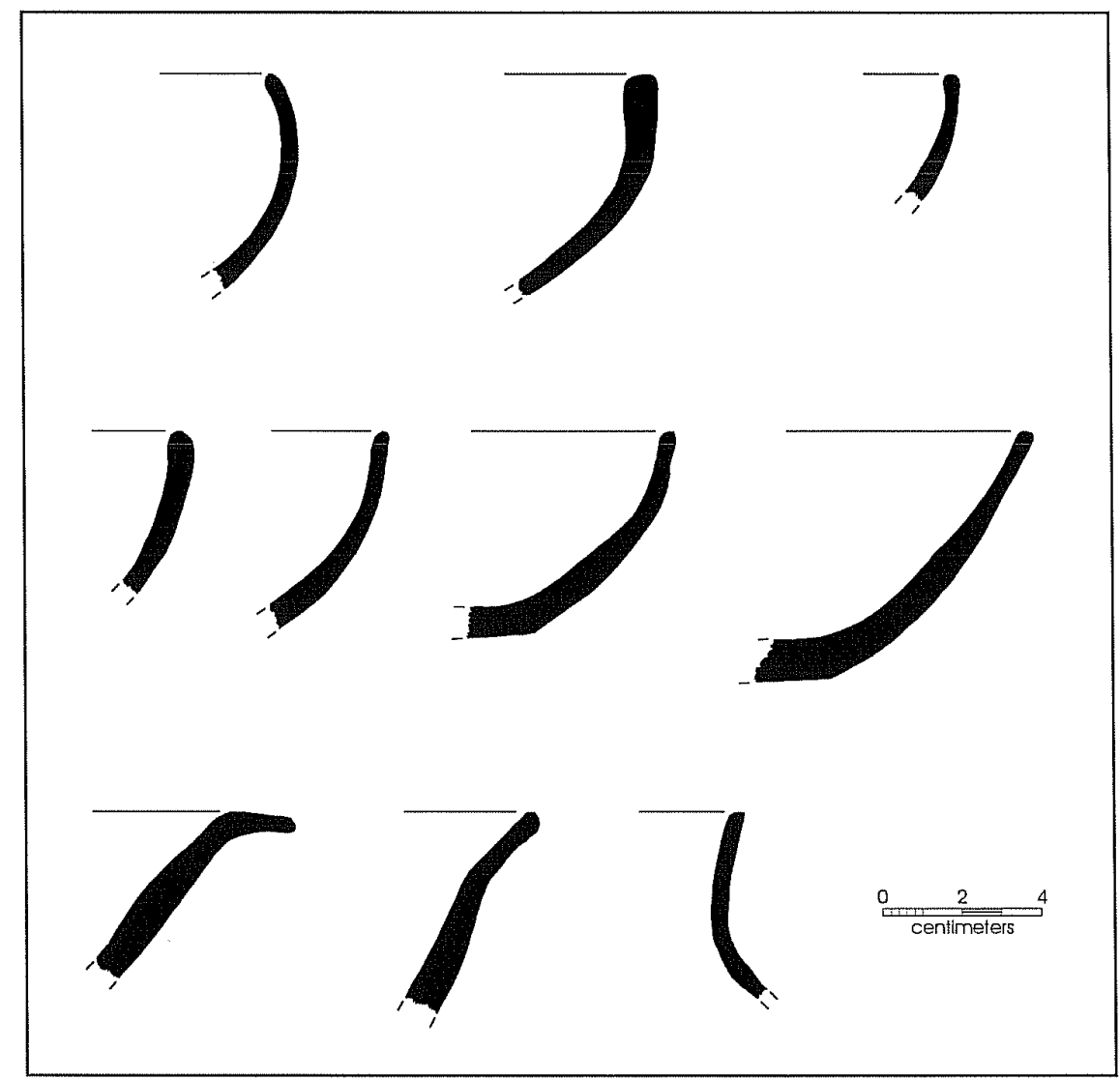

Figure 6-3. Vessel shapes and rim types from pottery found in the kiln.

\section{Tin-Glazed Wares (Majolicas)}

Majolicas are unrefined earthenwares with a lead glaze to which tin has been added to create an opaque, creamy white background. Vessel shapes are deep plates, bowls, and small cups. The small size of the majolica sherds recovered from these excavations makes it difficult to separate them into discrete decorative patterns. For this reason, the sherds have been sorted in the following manner: undecorated sherds were first removed into one group, sherds having touches of blue decoration that could not be identified as one particular pattern were then isolated, sherds with touches of polychrome were put into another group, and the remaining sherds which could be identified were then sorted into types. All of these types have been found on mission sites at San Antonio and Goliad, as well as elsewhere throughout the state.

\section{Undecorated Majolicas}

Of the 111 undecorated majolica sherds recovered, some may represent undecorated vessels, which were made throughout the eighteenth century (Lister and Lister 1974:30). Others are probably undecorated portions of otherwise decorated vessels.

\section{Blue on White}

Any tin-glazed sherd that has some indication of blue decoration but is too small to identify as to pattern is included in this group of 86. Many of them are probably from Puebla Blue on White vessels that were popular throughout the eighteenth century. The paste color of these wares is cream to pink. 


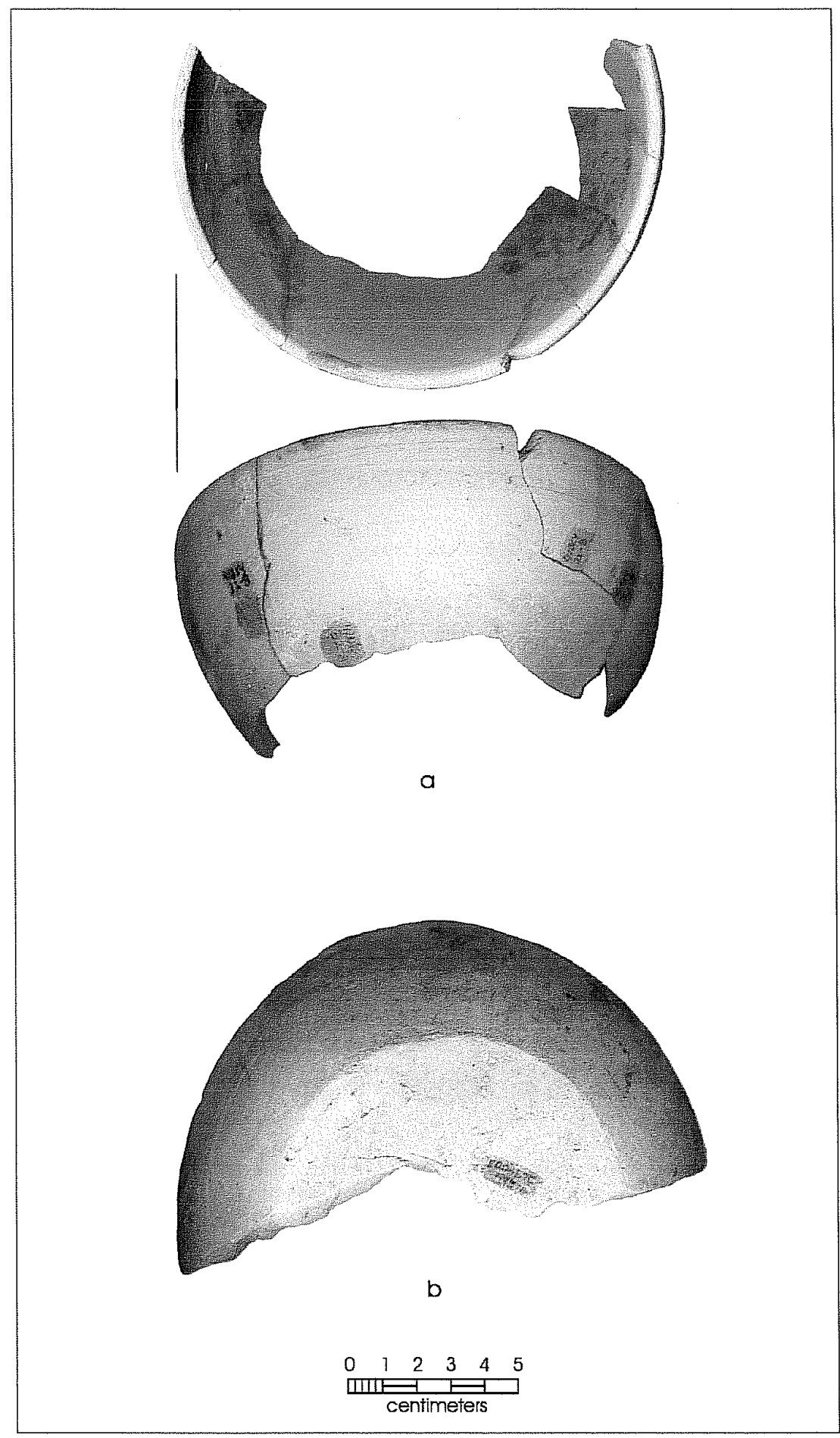

Figure 6-4. Examples of kiln-made wares: a) fragment of small bowl; b) fragment of the flat bottom of large container. 


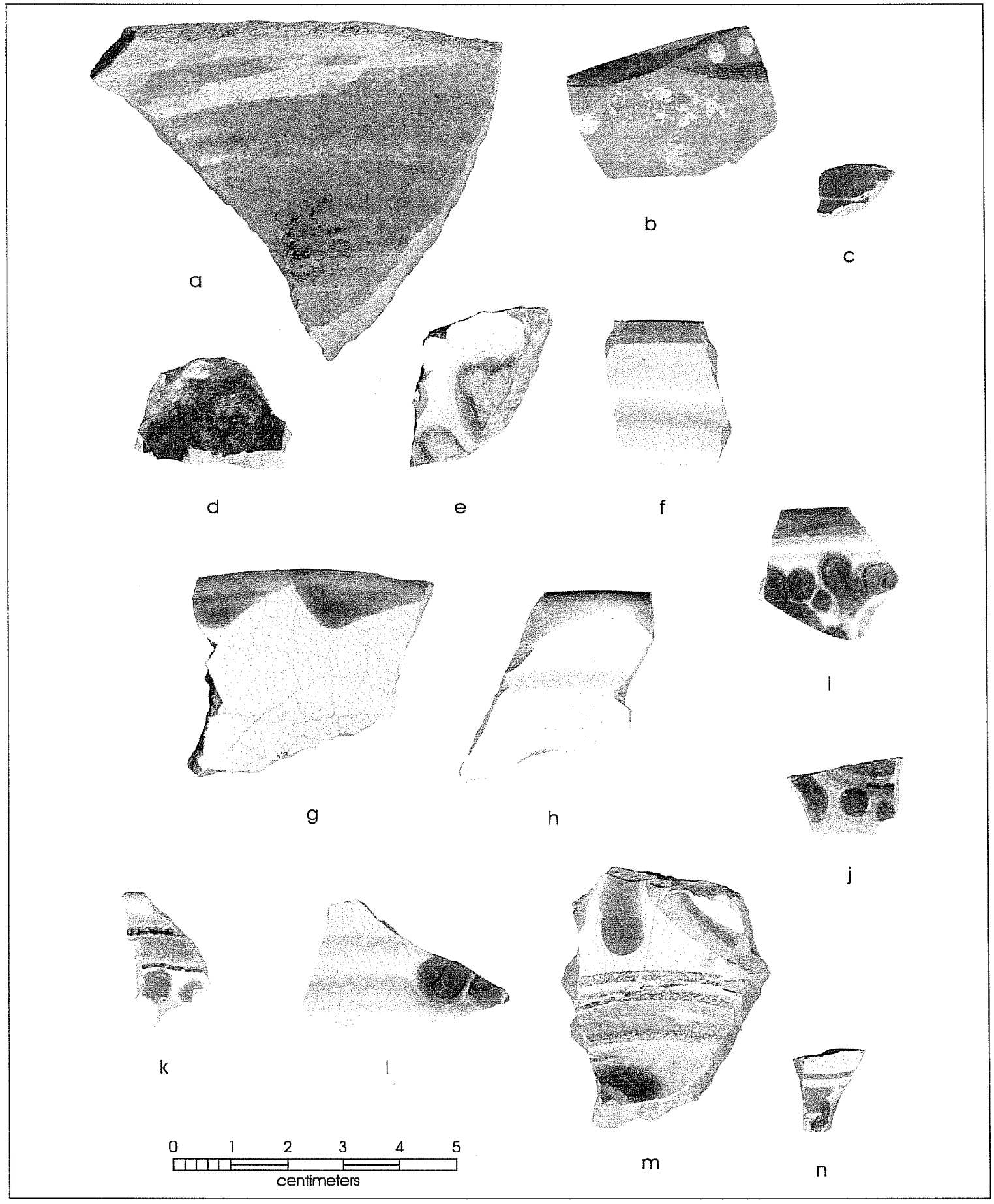

Figure 6-5. Examples of glazed Colonial ceramics: a) sandy paste lead-glazed ware; b) Galera lead-glazed ware; c) RedBrown lead-glazed ware; d) Black Luster lead-glazed; e) undefined polychrome tin-glazed; f) Plain Huejotzingo Banded; g) Wavy band Huejotzingo; h) Green wavy band Huejotzingo with extra band; i) San Agustín; j) Blue on Blue; k) San Elizario; 1) Puebla Blue on White II; m) Monterey Polychrome; n) Guanajuato. 


\section{Polychrome}

Sherds with touches of polychrome decoration too small to identify a decorative type are included in this group of 30 (Figure 6-5e). Many of these sherds have a red paste typical of the nineteenth-century polychromes.

\section{Huejotzingo Banded}

Vessels of this type $(n=21)$ generally have no decoration except for a band of color on and over the rim. Some have a simple blue or green band (Figure 6-5f). These were made throughout the eighteenth century (Goggin 1968:195). Others with a wavy blue or green band (Figure 6-5g) can be more tightly dated to ca. 1775 to 1825 (Seifert 1977). Occasionally, those with a green wavy rim band have an additional thin, parallel band below (Figure 6-5h).

\section{San Agustín}

The pattern of this type $(n=18)$ consists of floral designs in two shades of blue that nearly cover the glossy white background (Figure 6-5i). The back surface of the plates has interlocking blue loops. First attributed to the first quarter of the eighteenth century (Goggin 1968:189), this pattern appears to extend throughout the eighteenth century in Texas sites.

\section{Blue on Blue}

Sherds with a medium blue background and floral designs in darker blue (Figure 6-5j) have been attributed to the eighteenth century by Lister and Lister (1974:34-35). Schuetz (1969:56) described this type from Mission San Juan and Nickels (2000:97) from Mission Rosario at Goliad. These deep plates, typical of eighteenth-century Puebla potteries, have blue loops on the back. Four such sherds are in this collection.

\section{San Elizario}

This type has brown accents on a classic Puebla Blue on White pattern (Figure 6-5k). Blue petals with brown accents are suspended from narrow brown bands on either side of a broader blue rim band, and brown legs and beak accent a central crane-like bird. Ivey and Fox (1999:37) date this type from 1755 to 1780 in Texas. Sixteen sherds of this type were recovered.

\section{Puebla Blue on White II}

This variation of Puebla Blue on White appears only on cups and small bowls. The design consists of two or three narrow, pale blue bands under the rim on the exteriors of vessels (Figure 6-51). Below the bands are alternating darker blue petal-shaped dots. On some vessels, there is a trio of darker blue dots suspended from the blue bands. This type appears to have been made throughout the eighteenth century. Four of these sherds were recovered.

\section{Monterey Polychrome}

On this type, an orange rim band is surrounded by brown lines, with orange and yellow floral elements alternating with green sprays. It was popular from Florida to California in the late-eighteenth and early-nineteenth centuries, and is common on San Antonio Colonial sites. Sixteen Monterey Polychrome sherds are in this collection (Figure 6-5m).

\section{Guanajuato}

A new color combination appeared in the early nineteenth century (Figure 6-5n). It combined rust, green, and brown in an assortment of new designs (McKenzie 1989). The paste is consistently dark red and vessel shapes appear to have been influenced more by European ceramics than by those of Mexico. Only two such sherds are in this collection.

\section{French Faience}

One-half of a tin-glazed vessel was found in Level 8 of TU 32 inside the kiln (see Figure 5-6). The white glaze, the single blue band below the rim on the interior, and the flat base with no foot ring identifies it as faience (Miller and Stone 1970:Figure 11). This faience vessel is by far the largest fragment of faience so far recovered from an archeological site in Texas (Figure 6-6). Other Spanish Colonial site excavations on the San Antonio River have yielded a few sherds of this French ceramic type, Mission San Juan Capistrano (Schuetz 1969:57), the Alamo (Fox 1992:27; Schuetz 1973:22), and Mission Rosario (Gilmore 1974:53) for example. This type of vessel, with a diameter of $22 \mathrm{~cm}$ ( $8.5 \mathrm{in}$.) and a depth of $30 \mathrm{~mm}$ (2.25 in.), is referred to as a dessert plate (Brain 1979:37). 


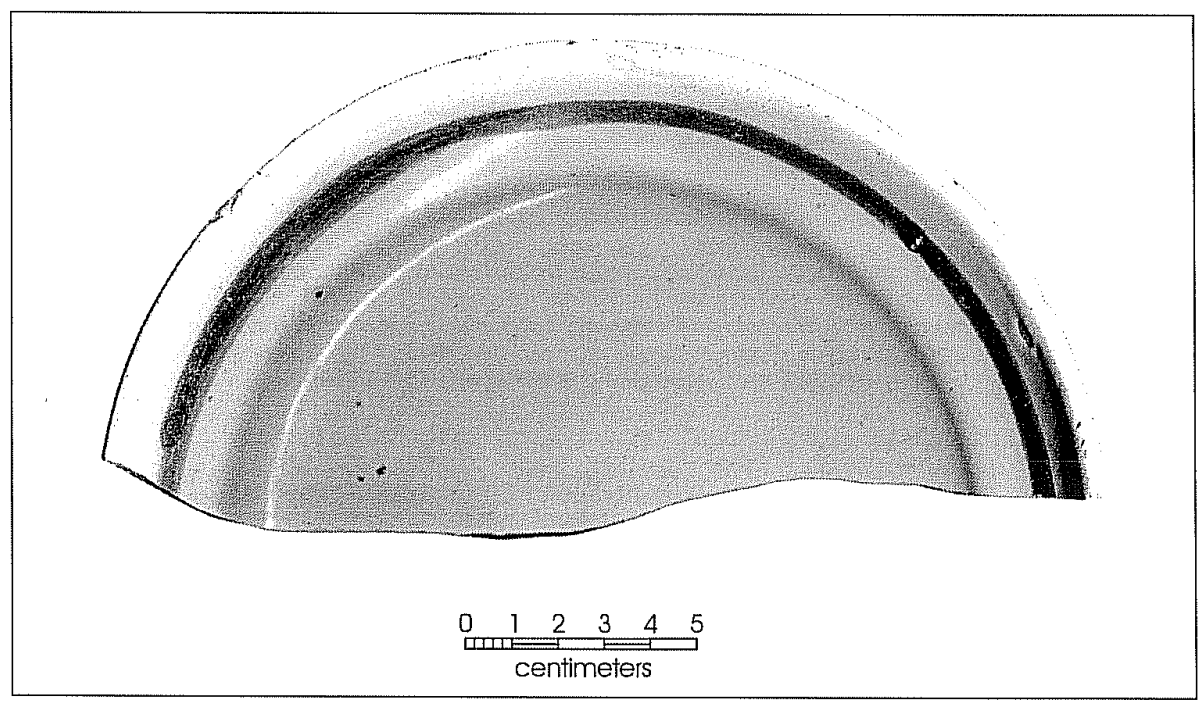

Figure 6-6. French Faience plate fragment from kiln (see Figure 5-6).

\section{White Earthenwares}

The refined white earthenwares recovered during these excavations include both undecorated sherds and those with various types of brightly colored decorations. Decorated white earthenwares appear to have replaced majolicas in the households of mission inhabitants. The British flooded the market with these wares in the 1790 s, causing many Mexican majolica makers to go out of business by 1802 (de Humboldt 1941:17).

The term whiteware is used here to include all white-bodied wares from the plain white earthenwares and ironstones imported from England during the late eighteenth century and the first half of the nineteenth century; through the plain White Granite wares made in U.S. factories in the last half of the nineteenth century; and the semi-porcelains popular from 1880 on into the twentieth century.

\section{Undecorated Whitewares}

The 403 sherds of this type in the assemblage may represent wholly undecorated vessels or undecorated portions of otherwise decorated wares described below.

\section{Edge Decorated}

Blue or green painting on the rim only was a popular form of decoration from the late-eighteenth to the late-nineteenth centuries, but the details changed through time, making it possible to date edge decorated whiteware in some detail (Stelle 2001). The 13 edge decorated sherds from this site include two in green and the rest in blue. Table 6-1 provides dating information on the types recovered, and Figure 6-7, a-f, shows examples of each.

Table 6-1. Dating Edge-decorated Whitewares (based on Stelle 2001:Table 1)

\begin{tabular}{|l|c|c|c|}
\hline \multicolumn{1}{|c|}{ Description } & Ct. & $\begin{array}{c}\text { Maximum } \\
\text { Popularity }\end{array}$ & $\begin{array}{c}\text { Production } \\
\text { Range }\end{array}$ \\
\hline Scalloped rim, impressed, curved lines (Figure 6-7a) & 3 & $1802-1832$ & $1795-1845$ \\
\hline Scalloped rim, impressed, straight lines (Figure 6-7b) & 3 & $1809-1831$ & $1795-1840$ \\
\hline Scalloped rim, impressed bud (Figure 6-7c) & 2 & $1813-1834$ & $1800-1850$ \\
\hline Embossed patterns (Figure 6-7d) & 1 & $1823-1835$ & $1820-1845$ \\
\hline Unscalloped, impressed rim (Figure 6-7e) & 1 & $1841-1857$ & $1825-1891$ \\
\hline Unscalloped, unmolded (Figure 6-7f) & 1 & $1874-1884$ & $1850-1897$ \\
\hline Indeterminate & 2 & -- & - \\
\hline
\end{tabular}




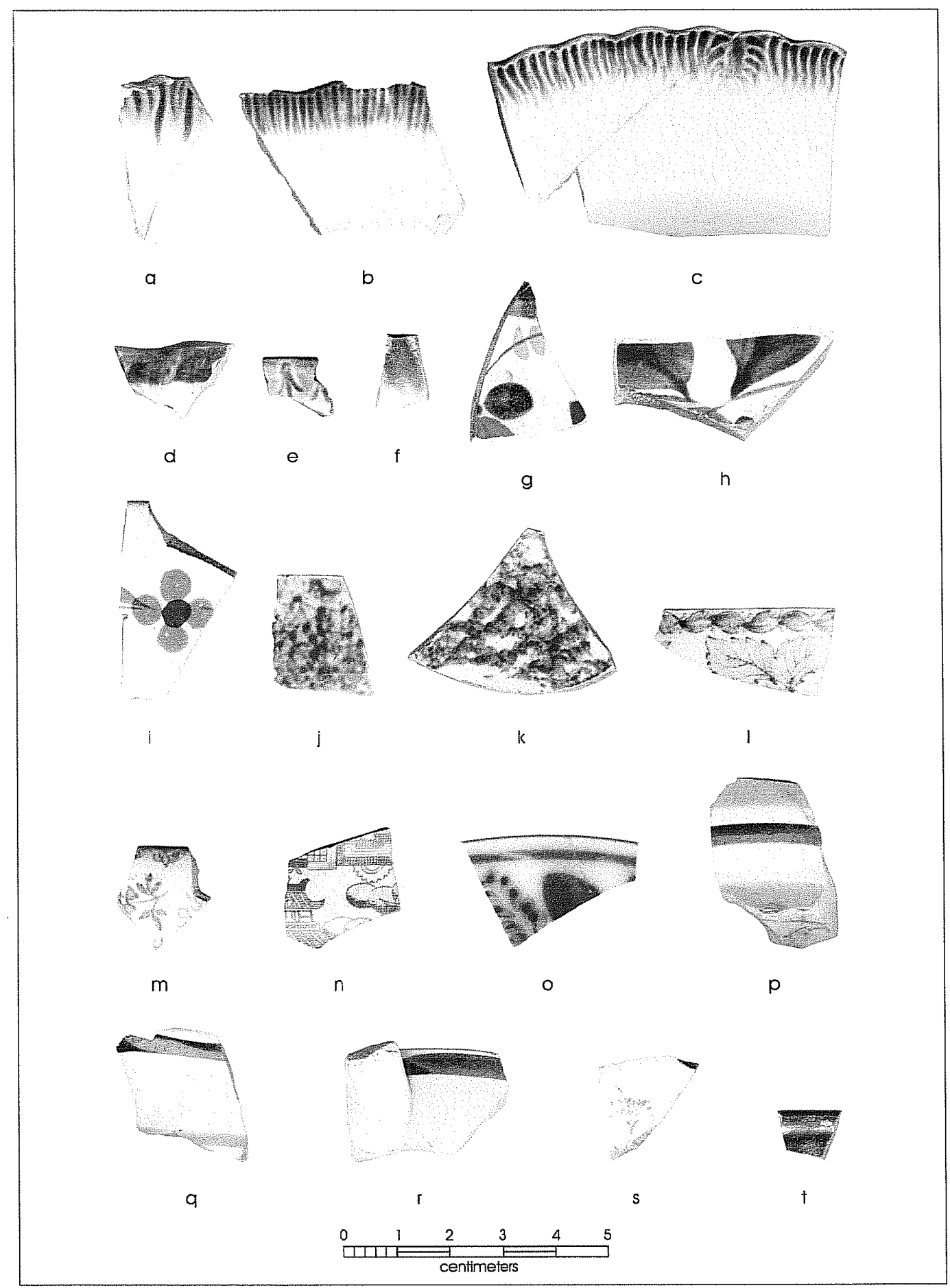

Figure 6-7. Examples of decorated white earthenwares: a-f) edge decorated sherds (see Table 6-1); g-i) handpainted; j) spatter decorated; k) sponge decorated; 1-n) transfer printed; o) flow blue transfer; p) banded slip; q) band and line; r) tea leaf ironstone; s) decalcomania; t) copper luster. 


\section{Hand-Painted Decoration}

A full color range of hand-painted decoration is present in this collection. The earliest color combination (brown, mustard yellow, and olive green) was popular from about 1795 to the 1820s (Noel Hume 1982:129). Wares painted with blue floral designs were popular in the 1820 s, followed by a new color group in the 1830s that consisted of red, black, and lighter shades of blue and green (Miller 2000:93). All of these color combinations are represented in the 82 sherds in this collection. They are distributed as shown in Table 6-2, and examples are shown in Figure 6-7, g-i.

\section{Spatter Decoration}

This type of decoration consists of fine, close-set dots (Figure 6-7j) accomplished by blowing dry powdered paint or powdered paint mixed with oil onto the biscuit body (Kelly and Kowalsky 2001:6). Most spattered vessels also have hand-painted designs such as a peafowl or rooster, or a flower in the center. The 23 sherds in this collection are spattered with red, blue, or bright green and one has part of a rooster design present.

\section{Sponged Decoration}

Sponged decoration is created by merely dipping a sponge in paint and applying it on the surface of a vessel, which produces a more open result, with much of the white background showing through (Figure 6-7k). Most objects decorated in this way have no other decoration applied. This type of decoration was much in demand from the 1840 s to the 1880s (Hughes 1967:71). Sponged decorations from this site (11 sherds) are done in blue, green, and red.

\section{Cut Sponge Stamped}

Invented in Scotland and introduced in England in 1845 (Robacker and Robacker 1978:80), this type of decoration uses the cross-section of a sponge stem with a design cut into it. This is used to stamp decorative patterns onto the vessels, usually in company with hand-painted designs. This collection $(n=10)$ includes eight different patterns in purple, red, bright green, and a combination of green and brown.

\section{Transfer Printed}

Designs for this type of decoration were engraved on copper plates and impressed on paper. The paper print was applied to an unglazed earthenware vessel, which was then glazed and fired in a kiln. This type of decoration on whiteware was popular throughout the first half of the nineteenth century (Figure 6-7, 1-n). The technique has been used on other types of ceramics well into the twentieth century (Miller 2000:94). Transfer prints on the 28 sherds in this collection are done in blue, red, gray, green, and purple.

\section{Flow Blue Transfer}

A new technique was invented ca. 1825 in which chlorinated vapor was introduced into the kiln, blurring the print. It was used primarily on blue transfer prints, but also appears occasionally on purple and brown prints (Ray 1974:69). Only the blue type is represented on the eight sherds from these excavations (Figure 6-7o).

\section{Banded Slip or Dipped Decoration}

This whiteware type can be identified by the application of colored clay slips in bands and/or dots, worms, annular designs, and engine-turned or rouletted decoration. The colors used include bright blue, gray, various shades of earthen brown, yellows, greens, and black (Figure 6-7p). Vessels include mugs, bowls, cups, and covered dishes (Majewski and O'Brien 1987:163). The 37 sherds in this collection are too small to be able to identify vessel shapes, but nearly every color is represented among them.

\section{Band and Line Decoration}

Vessels with one or two thin bands of color below the rim became common in the last quarter of the nineteenth century. This type of decoration was most often used on "hotel" wares and can still be found in use today (Miller 2000:92). The

Table 6-2. Dating Hand-painted Whitewares

\begin{tabular}{|l|c|c|}
\hline \multicolumn{1}{|c|}{ Colors } & Ct. & Approx. Dates \\
\hline Brown, mustard yellow, and olive green (Figure 6-7g) & 9 & ca.1795-1820s \\
\hline Blue floral designs (Figure 6-7h) & 24 & $1820 \mathrm{~s}$ \\
\hline Red, black, and lighter shades of blue and green (Figure 6-7i) & 43 & $1830 \mathrm{~s}$ \\
\hline Indeterminate & 6 & -- \\
\hline
\end{tabular}


body on which it is used is generally heavy semi-porcelain. One sherd of this type was recovered (Figure 6-7q).

\section{Tea Leaf Ironstone}

Plain white ironstone first appeared in this area after the Civil War and was popular for the remainder of the century. However, by the 1880 s people were looking for something new. An Englishman had started adding copper luster bands and tea leaves to ordinary ironstone in the $1850 \mathrm{~s}$, and by the 1880 s this style had become very popular in America. The craze died out by 1910 (Ray 1974:221-222). Four fragments of this ceramic type were recovered during these excavations (Figure 6-7r).

\section{Decalcomania}

This technique was developed in the mid-nineteenth century but was particularly popular in America around 1900 (Yakubik 1990:305). Since the decal design was applied over the glaze, it is possible by holding a sherd up to the light to see that the surrounding areas appear glossier than the decal design (Durrenberger 1965:10). Without the protection of the glaze, the pattern is often badly damaged in archeological contexts. Decal decoration has been used on both whitewares and porcelains (see the section on porcelains below). Three whiteware sherds with decal decoration are in this collection, all in poor condition (Figure 6-7s).

\section{Copper Luster}

Luster decoration is formed by applying a thin metallic film to a ceramic body. Copper luster was commonly applied to a dark clay-colored body. Luster-decorated pottery was made only by English potters and was produced for a lengthy period after about 1840 (Godden 1975:215). The single copper luster sherd recovered during these excavations has a red paste and is covered on the inside with a white slip (Figure 6-7t).

\section{Late Majolica}

This is a typically Victorian ceramic, first introduced ca. 1850 (Godden 1975:272). A coarse earthenware body is covered with opaque glazes in light and dark green, brown, blue, yellow, and red. Domestic ware in this majolica dates from the early 1860s (Hughes 1967:165). Two late majolica sherds from TU 46, Level 2, have an opaque green glaze. They are too small to tell the vessel shape or size.

\section{Other Refined Earthenwares}

\section{Yellow wares}

This type has a yellow body covered with a clear (Figure 6-8a) or dark brown glaze (Figure 6-8b). Made first in England in the late-eighteenth century and exported to the United States, yellow ware soon was being made here as well (Gallo 1985). It was primarily made as kitchen ware in the form of mixing bowls, baking pans, and pitchers. Twelve yellow ware sherds were recovered.

\section{Stonewares}

Stonewares have a hard, vitrified body closer to porcelain than to earthenware. It was frequently used to make containers for liquids, and for food storage vessels.

\section{European Stoneware}

This type of stoneware has a fine, gray paste and a dull gray or brown glaze. It was frequently made into ink bottles and other liquid containers. Three such sherds were recovered (Figure 6-8c).

\section{American Stoneware}

A surprising number $(n=17)$ and variety of sherds of American-made stoneware vessels are included in this collection (Figure 6-8, d-f). These would probably represent households that were in existence on the mission compound in the late-nineteenth and early-twentieth centuries. The glazes on the samples in this collection were all in use in the period between ca. 1850 and 1920 (Greer 1981).

\section{Porcelains}

\section{Chinese Porcelain}

Chinese porcelains have a thin, delicate body and a glassy glaze (Figure 6-8g). The three Chinese sherds recovered from these excavations were decorated with red and beige painted designs over a stark white body and are similar to other sherds excavated at the missions (Hard et al. 1995:43; Nickels 2000:97). Delicate porcelain cups and bowls were imported to Acapulco on the Manila galleons, then transported by mule to Mexico City during the Colonial period and until the trade was discontinued ca. 1815. 


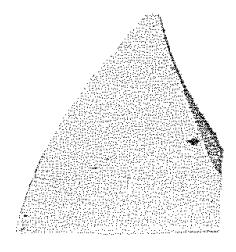

a

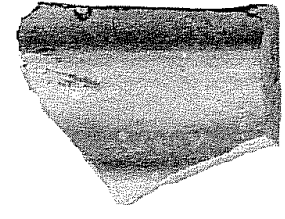

d

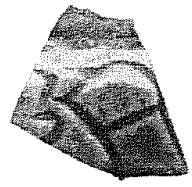

b

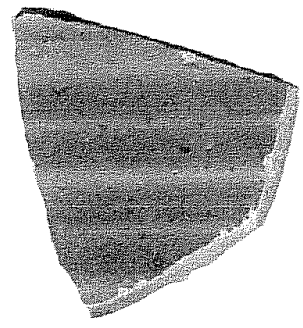

C
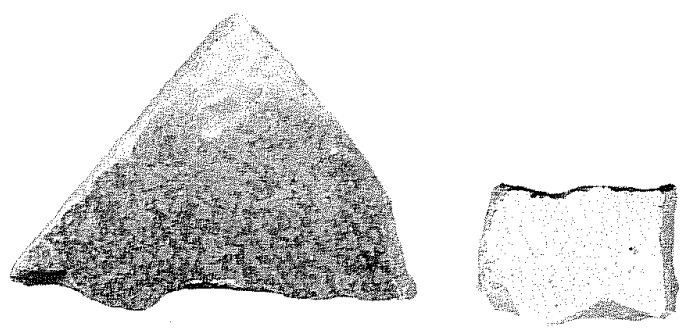

e

$f$

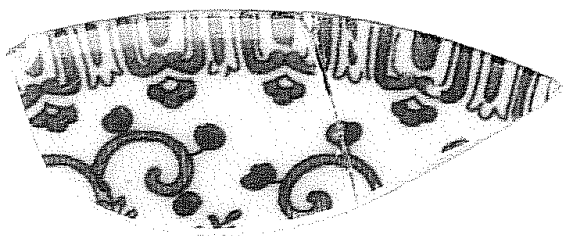

g

h

$\begin{array}{lccccc}0 & 1 & 2 & 3 & 4 & 5 \\ \text { CIIIL } & =\end{array}$

Figure 6-8. Examples of other refined earthenwares: a) yellow ware with a clear glaze; b) molded yellow ware with a dark brown glaze; c) European stoneware; d-f) American stoneware; g) Chinese porcelain; h) European porcelain (transfer printed).

\section{European Porcelain}

Hard paste porcelain was made in Europe until late in the nineteenth century, then in the United States as well. It has a stark white surface and a thick glaze that is neither crazed nor discolored (Majewski and O'Brien 1987:127). Most of this type of porcelain in this collection (51 sherds in all) is undecorated, but a few sherds bear decal or hand-painted decoration. Several of the sherds have a blue transfer oriental-looking design that apparently was sold in San Antonio in the early-twentieth century (Figure 6-8h), as it is found in numerous late deposits in town. 


\section{BOTTLE/CONTAINER GLASS}

There are 1,302 glass container sherds in the collection from these excavations. Manufacturing techniques, makers' marks, and to a lesser extent, glass colors can be used to estimate the dates of glass. With the exception of color, however, most dating of glass requires large fragments of the base or lip, which are rare in this collection. Glass color is the only characteristic that can be assessed on all fragments. A few colors are known to date from certain time periods, but most colors cannot be assigned with certainty to a particular time frame.

\section{Glass Colors}

The "natural" color of glass is one of various shades of bluegreen (referred to in this report as "aqua"), depending on the source of sand melted to make the glass (Munsey 1970:37). Various additives can give glass different colors or remove all colors, producing "clear" or "colorless" glass. There was little if any clear glass made in the United States before 1840 (Kendrick 1967:21), but some clear glassware was being made in Puebla from the 1540s through the nineteenth century (Deagan 1987:129-130). Clear glass was always fairly rare, however, until about 1880 , when food began to be preserved in glass jars and the demand for clear glass increased dramatically (Munsey 1970:55). At that time, manganese was added to glass to decolorize it. When left in sunlight for a long period of time, the glass begins to turn a shade of amethyst (sometimes called lavender or "suncolored" glass). The use of manganese to decolorize glass continued until 1915, when the major source of this mineral, in Germany, became unavailable. Manufacturers in the U.S. turned to selenium as a decolorizing agent. Clear glass with selenium in it turns a light amber-yellow when exposed for long periods to sunlight. By about 1930, manufacturers of clear glass switched to arsenic, which does not change color in sunlight (Munsey 1970:55). Thus, although colorless clear glass may come from any time in the history of Espada, it is much more likely to be twentieth century in origin. Amethyst clear glass can be dated from roughly 1880 to 1915 . Amberyellow clear glass can be dated from 1915 to 1930 .

Other colors can also be given dates. A shade of olive to brown-olive glass was in use, especially for wine bottles, from the Colonial period through the nineteenth century. A very dark green glass, so dark it appears black unless held to a bright light, was in use during the nineteenth century until about 1880 (Munsey 1970:37). Bright green, very clear glass is twentieth century in origin. Other shades of green, not described here, are not datable. Cobalt blue bottles were being made for medicines beginning around 1933 (Miller and Pacey 1985:45). Most brown glass is twentieth century in origin, but there were shades of dark amber-brown that were in use in the nineteenth century, so brown glass cannot be reliably dated.

Glass fragments were dated by color when possible and tallied in the appropriate categories in the tables in Chapter 5. Overall glass color totals are listed in Table 6-3. Looking at Table 6-3, and considering the previous discussion, it will be seen that the majority of glass fragments cannot be positively dated. Those that can be dated reflect the use of Mission Espada from the eighteenth through the twentieth centuries.

\section{Glass Manufacturing}

Glass has been made for thousands of years (Munsey 1970:6). The manufacturing techniques in use during the inhabitation of Mission Espada can be used to estimate the dates of some bottles and containers.

At the beginning of the eighteenth century, most bottles were still being free blown, that is, they were made by an artisan blowing and shaping the bottles by hand. In the first quarter

Table 6-3. Distribution of Bottle and Container Glass by Color

\begin{tabular}{|c|c|}
\hline Color & Ct. \\
\hline \begin{tabular}{|l} 
Olive \\
\end{tabular} & 125 \\
\hline "Black" & 29 \\
\hline Clear (amethyst) & 17 \\
\hline Cobalt blue & 15 \\
\hline Clear (amber-yellow) & 94 \\
\hline Bright Green & 25 \\
\hline Clear & 628 \\
\hline Red & 3 \\
\hline Other green & 6 \\
\hline Aqua & 163 \\
\hline Brown & 187 \\
\hline Milk glass & 7 \\
\hline Brown-black (modern) & 3 \\
\hline Total & 1,302 \\
\hline
\end{tabular}


of the nineteenth century, molded bottles, blown into two or three-piece molds, became more common, and by 1840 they were the standard. These bottles have a mold seem on the side that extends to just below the lip (Adams 1971:16).

In 1903, Michael J. Owens patented an automatic bottlemaking machine that produced a complete bottle without the need for the artisan. Bottles made in Owens' machine had mold lines all the way to the top of the lip (Lorrain 1968:43). This process was adopted by almost every bottle maker within a few years.

The marks left by various manufacturing techniques allow identification of some bottle fragments. Hand-blown bottles usually have pontil (the metal rod used to hold the bottle during shaping) marks on their base and occasionally other tool marks (Munsey 1970:47-48). Laid-on lips were applied to both free-blown and later to mold-blown bottles, from about 1840 to 1870 (Newman 1970:73). Lips shaped with lipping tools became more common after about 1850 . Lipping tools created a more or less standardized shape for various purposes (see Munsey 1970 for detailed discussion).

Some bottle shapes can also provide an estimate of date. The first panel bottles appeared ca. 1867 (Lorrain 1968:40). The first round milk bottles were made in the mid-1880s (Lorrain 1968:44). Bitters, usually sold in distinctive bottles, was a popular medicinal drink during the last half of the nineteenth century (Munsey 1970:111-112). The cork was the predominant bottle closure until after standardization, made possible by the automatic bottle machine, when screwtop and crown cap bottles were adopted (Miller and Pacey 1985:45). A Coca Cola bottling works opened in San Antonio in 1903 (San Antonio Light 1969), and the classic Coca Cola bottle shape was adopted in 1915 (Munsey 1970: 106).

A few glass bottles and bottle fragments in the collection are large enough to identify manufacturing methods or provide other datable indications. They are listed in Table $6-4$, and a few of the more interesting bottles are discussed.

One piece of clear glass, the thick bottom of a hand-blown bottle, appears to have been chipped into a scraper in a fashion similar to techniques used by Native Americans on chert (Figure 6-9a). This piece was recovered from the Northwest Gateway area, in Level 1 of TU 44. The use of glass in this fashion has been seen in proto-historic and other Colonial sites.
The bottom of a hand-blown fancy bottle was recovered from Level 3 of TU 18. The aqua bottle has a pontil mark on the base. It is formed in a square with scallops on the sides (Figure 6-9b). The unevenness of these scallops also shows the bottle was not made in a mold. It probably dates from the Colonial period to the early-nineteenth century.

A small aqua bottle base was recovered from Level 3 of TU 16. This fragment appears to have been hand-blown, with a large kickup (the bottom of the bottle was pushed up into the bottle to make the bottle appear to hold more than it does) that had been disguised by adding glass to the concavity in the bottle bottom and roughly smoothing it (Figure 6-9c).

Another example of early clear glass, found in Level 3 of TU 6, is the lip of a bottle that may have had a "pulled" neck in which the narrowing of the neck is created by pulling it while the glass is still hot. The stretching leaves thin marks on the glass. Subsequently, the lip was applied and shaped with a lipping tool (Figure 6-9d). This bottle was probably made around the middle of the nineteenth century, but could have been made any time before 1903 .

Another clear bottle lip, made for a medicine bottle, is made on a molded bottle and shaped with a lipping tool (Figure 6-9e). It was recovered from Level 3 of TU 19. It probably dates between about 1880 and 1903 .

A small fragment of a brown bottle lip, probably from a liquor bottle, recovered from Level 1 of TU 20, was also made with a lipping tool. The applied glass is smoothed on the outside but left rough on the inside of the bottle (Figure 6-9f). The heavy patina is common on older brown glass.

Two complete bottles are in the collection, both machine made. The first is a small medicine bottle made for a cork closure. The second is a "Dixie Brand" soda bottle (Figure 6-9g). The embossed lettering near the bottom states "PROP. OF SAN ANTONIO/CHIC CHIC BOT. WORKS... $2451 \ldots 6$ 1/2 FL. OZS." The number " 2451 " is in much smaller letters than the others. The bottle bottom has "DIXIE" embossed on it. The lip is made for a crown cap. Although this particular brand and the Chic Chic Bottling Works has not yet been identified in the archives of San Antonio businesses, it is probable that the bottle was made in the 1920s and 1930s, when local sodawater bottlers often made their own brands. 
Table 6-4. Diagnostic Glass

\begin{tabular}{|c|c|c|c|c|}
\hline Unit & Level & Ct. & Color & Description \\
\hline 1 & 3 & 1 & Aqua & Bottle base, probably from a Coca Cola bottle. Post 1915 (Munsey 1970:106). \\
\hline 6 & 3 & 1 & Clear (yellow) & Fragment of small bottle base. Post 1915. \\
\hline 6 & 3 & 1 & Clear & Bottle lip. Neck appears to have been "pulled." Lipping tool used. Probably ca. 1840-1903. \\
\hline 9 & 1 & 1 & Clear (amethyst) & Fragment with etched bands. Probably ca. 1880 to 1915 . \\
\hline 9 & 2 & 3 & Aqua & Molded bottle with some lettering on side. Probably ca. 1840-1903. \\
\hline 14 & 2 & 1 & Aqua & Bottle lip from molded bottle. Lipping tool used. Probably ca. 1840-1903. \\
\hline 16 & 3 & 1 & Aqua & $\begin{array}{l}\text { Base of small ( } 2.6 \mathrm{~cm} \text { in diameter) bottle. Deep kickup has been disguised by adding glass to } \\
\text { the cavity in the base of the bottle. Tool marks and lack of mold seams suggest it was hand- } \\
\text { blown. } 18 \text { th to early } 19 \text { th century. }\end{array}$ \\
\hline 17 & 3 & 1 & Aqua & Fragment of Coca Cola bottle. Post 1915 (Munsey 1970:106). \\
\hline 17 & 3 & 1 & Clear & $\begin{array}{l}\text { Machine made rectangular bottle, narrower at the top than the bottom, with a chevron pattern } \\
\text { embossed on three sides. Base mark shows it was made by the Knox Glass Bottle Co. of } \\
\text { Mississippi, sometime between } 1932 \text { and } 1953 \text { (Toulouse } 1971: 271 \text { ). }\end{array}$ \\
\hline 18 & 2 & 1 & Clear & Bottle base with pontil mark. 18th to early 19 th century. \\
\hline 18 & 3 & 3 & Aqua & $\begin{array}{l}\text { Bottle base, square shaped, with tool marks on sides and with pontil mark on the base. Hand- } \\
\text { blown. Probably prior to } 1840 \text {. }\end{array}$ \\
\hline 19 & 3 & 1 & Clear & Molded medicine bottle neck. Lipping tool used. Probably ca. 1840-1903. \\
\hline 20 & 1 & 1 & Aqua & Fragment of applied bottle lip. Probably ca. 1840-1903. \\
\hline 20 & 1 & 1 & Brown & Fragment of bottle lip shaped with lipping tool. ca. 1840-1903. \\
\hline 22 & 1 & 1 & Olive & Bottle base, probably hand-blown. 18th to early 19 th century. \\
\hline 22 & 1 & 1 & Brown & Brown bottle lip, made for a crown cap. Post 1903. \\
\hline 22 & 1 & 1 & Clear & Fragment of clear glass with blue painted "Tan..." logo. 20th century. \\
\hline 23 & 1 & 1 & Clear & Screw jar lip. Machine made. Post 1903. \\
\hline 23 & 1 & 1 & Aqua & Bottle lip made for a crown cap. Post 1903. \\
\hline 23 & 6 & 1 & Clear & Complete "Dixie" brand soda bottle. \\
\hline 32 & 3 & 1 & Clear & Screw jar lip. Machine made. Post 1903. \\
\hline 34 & 2 & 1 & Clear & $\begin{array}{l}\text { Machine made small bottle, with cork lip, probably for medicine. Markers' mark indicates the } \\
\text { bottle was made by the Owens Bottle Co. between } 1911 \text { and } 1929 \text { (Toulouse 1971:393). }\end{array}$ \\
\hline 34 & 2 & 1 & Brown & Brown bottle base, probably machine made. \\
\hline 43 & 1 & 1 & Clear & Screw jar lip. Machine made. Post 1903. \\
\hline 44 & 1 & 1 & Clear & Hand-blown bottle base, worked into scraper. Colonial. \\
\hline 46 & 1 & 1 & Aqua & Bottle base, probably machine made. Post 1903. \\
\hline \multicolumn{2}{|c|}{ Surface } & 1 & "Black" & Fragment of a bottle kickup. Probably $1840-1890$. \\
\hline
\end{tabular}

\section{OTHER HOUSEHOLD ITEMS}

\section{Caps and Tops}

None of the various types of bottle stoppers that had been invented by 1885 was totally satisfactory for the bottling of carbonated beverages. In 1892, William Painter of Baltimore invented the "crown cork," a metal cap with a corrugated flange, lined with a cork disk (Vaughan 1997:217). In 1930, the addition of a foil liner over the cork for the first time protected beer from reacting with the cork (Maxwell 1993:95). Unfortunately, none of the 19 crown caps recovered from these excavations still retains lining materials. However, it is safe to say that they must have accumulated after 1892 . They may have been deposited by occupants of houses within the mission compound or by later mission visitors. They all came from Levels 1,2 , or 3 in the excavations.

In the $1960 \mathrm{~s}$, the pop-top or tab-top was invented to allow the opening of beer cans without an opener. This was followed in the 1970 s by the pull-ring. Both of these openers were abandoned soon afterwards in favor of stay-tab devices that stayed with the can (Vaughan 1997:210). The 11 tabtops and ring tops in this collection, all from Levels 1 and 2 , are a product of later visitors to the site rather than Colonial or nineteenth-century mission residents. 


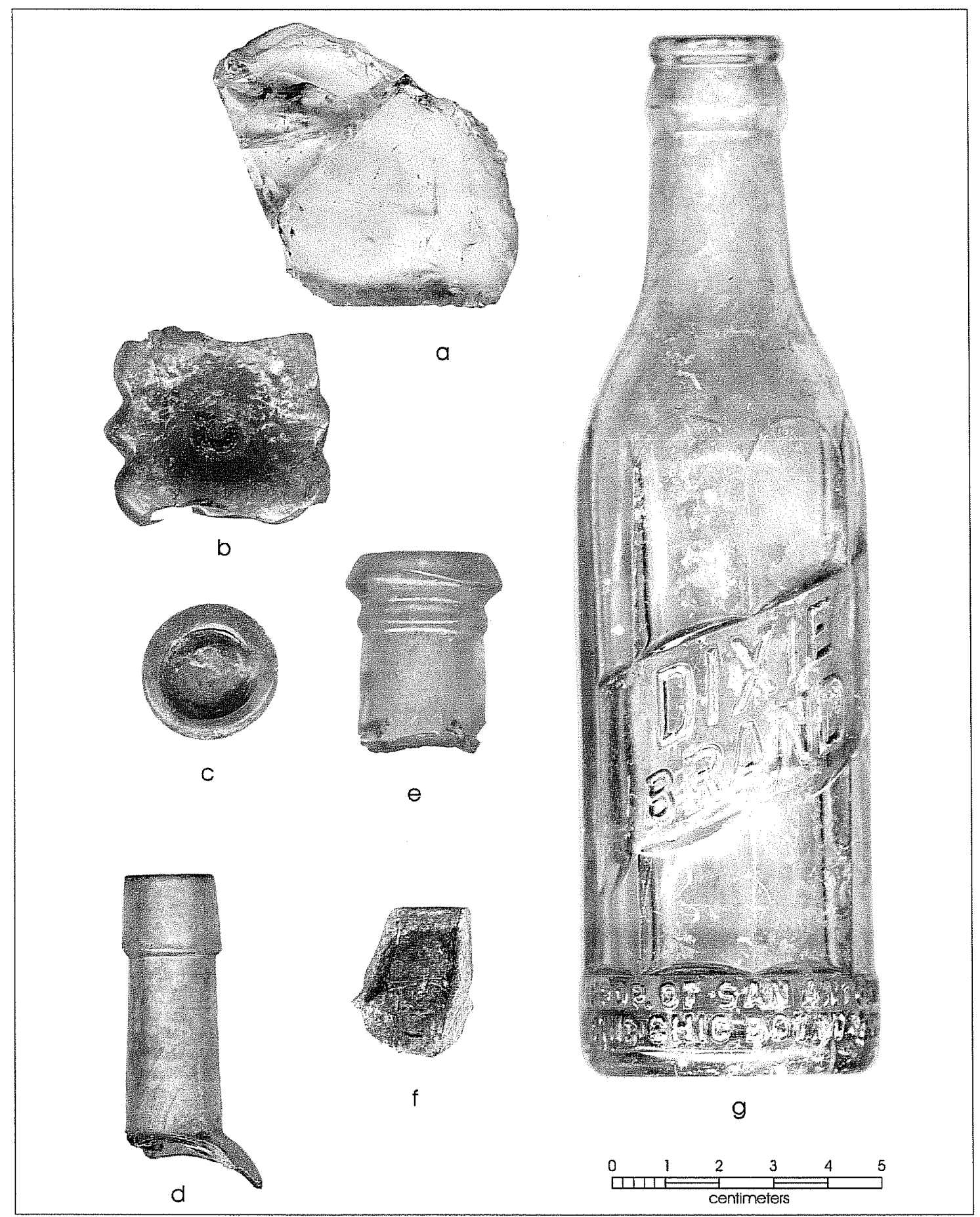

Figure 6-9. Examples of diagnostic glass: a) chipped glass bottle bottom; b) bottom of a free-blown bottle; c) base of small bottle with disguised kickup; d) clear bottle lip, e) medicine bottle molded, with lip applied with lipping tool; f) fragment of bottle lip interior, showing roughly applied glass; g) small machine-made medicine bottle; h) "Dixie Brand" soda bottle. 


\section{Table And Kitchen Wares}

Two segments of knife blades are the only table wares in the collection. Recovered from the upper levels in TU 18 (Level 2) and TU 19 (Level 1), neither can be securely dated by the other artifacts found in the same level since the deposits contain both eighteenth- and nineteenth-century materials.

A section of the rim of a large, heavy copper cooking vessel, estimated to be $38 \mathrm{~cm}$ ( $15 \mathrm{in}$.) in diameter, was recovered from the bottom of the pottery kiln in Drainage System A (TU 32, Level 8). One copper rivet that was once part of the handle attachment is still in place. Fragments of the lower part of the vessel are still attached to the rim, and these suggest by their location and shape that the entire vessel was hammered from one large sheet of copper. The craftsmanship is similar to that of Spanish Colonial vessels. Several similar copper vessels were recovered during archeological investigations at Mission Espiritu Santo in Goliad (Mounger 1959:207).

\section{Miscellaneous Household Items}

Two cast iron stove fragments were found in Level 2 of TUs 19 and 23. Cast iron stoves appeared in South Texas about 1860 (Crosby 1977:188).

Thirteen fragments of the thin, curved glass that represent the chimneys of oil lamps were recovered during this project.

A section of a coffee mill came from Level 2 of TU 20 . Coffee mills were being manufactured as early as 1832 in New England (Herskovitz 1978:67). The artifacts from this level include a mixture of eighteenth- and nineteenth-century ceramics, but it is unlikely that a coffee mill would have been used until the last part of the nineteenth century in this area, when Anglo-American cuisine began to be accepted. When roasted coffee beans became available in local stores, it was still not possible to buy ground coffee because it would rapidly lose its flavor unless used immediately (Buxton 1957:210). According to the 1927 edition of the Sears, Roebuck Catalogue (Mirken 1970:968), coffee grinders were still on the market at that time.

An interesting object from TU 7, Level 2, appears to be a fluting or crimping iron (Franklin 1976:67) for use on women's clothing or curtains. This also probably dates to the late nineteenth century.

\section{Personal Items}

\section{Beads}

Glass trade beads are found on eighteenth-century sites throughout Texas (Corbin et al. 1980:123; Harris et al. 1965: 287-363; Schuetz 1969:58-62; Tunnell and Newcomb 1969:106-112). Fifty-four trade beads were recovered during this project (Table 6-5).

R. King Harris spent many years identifying and classifying these beads, and the following identifications and comparative dates are taken from his work when possible. The sizes used in Harris' descriptions for beads from these excavations are small (2-4 mm), medium (4-6 mm), and large (over 6 $\mathrm{mm}$ ), and the colors are taken from Bustanoby (1947). The descriptions are taken from Harris and Harris (1967:141144). Harris' dates are derived from a compilation of bead collections from dated sites.

Twenty-four (44.4\%) of the trade beads were recovered from the Northwest Gateway units. The units along the Hike-andBike Trail also yielded 24 beads. Six additional beads $(11.1 \%)$ were recovered from TU 34 in the fill in the pit near the pottery kiln. The total bead collection includes both the beads recovered during the unit excavations and beads recovered by floating the soil samples recovered from selected units. Examples of each type described below can be seen in Figure 6-10.

The two most common beads are Harris No. 48 (Figure 6-10c) and No. 80 (Figure 6-10j). Both are small garter beads, probably intended for sewing onto garments.

Square jet rosary beads have been excavated from Spanish Colonial sites throughout the southwest and the Caribbean (Deagan 1987:182; Gilmore 1975:132; Ricklis 2000:87; Schuetz 1969:46). Three were recovered during this excavation (Figure 6-10, 1-n); two from TU 31, another, better made, from TU 26, is shaped into a thin square with one flat side, the others shaped into a flat pyramid. Two holes are drilled through corners of the rectangle in such a way that they can be double strung (Schuetz 1969:46, Plate 21g).

Coral beads (Figure 6-10k) have been identified at Mission Rosario and at San Juan Bautista in Mexico (Harris et al. 1999:392). Harris et al. (1999) believe these beads date from between 1750 and 1780 and were used in rosaries given to Native Americans. 
Table 6-5. Bead Types Recovered (types based on Harris and Harris 1967 when noted)

\begin{tabular}{|c|c|l|}
\hline Type & Count & \multicolumn{1}{|c|}{ Description } \\
\hline Harris No. 10 & 1 & $\begin{array}{l}\text { Large, Peacock Blue, opaque, barrel-shaped necklace bead of simple construction. The glass has fine lines } \\
\text { running lengthwise with the bead, giving it a texture reminiscent of striped sugarcane (1700-1836). }\end{array}$ \\
\hline Harris No. 18 & 1 & Large, black, opaque, spherical bead of simple construction (1700-1740). \\
\hline Harris No. 46 & 1 & $\begin{array}{l}\text { Small, Peacock Blue, opaque, donut-shaped garter bead of simple construction. The glass of this bead has a } \\
\text { sugar cane-like texture (1700-1836). }\end{array}$ \\
\hline Harris No. 48 & 13 & Small, dark Bluebird Blue, translucent, donut-shaped garter bead of simple construction (1700-1836). \\
\hline Harris No. 49 & 2 & Small, clear, donut-shaped garter bead of simple construction (1700-1836). \\
\hline Harris No. 50 & 2 & $\begin{array}{l}\text { Small, black, opaque, donut-shaped garter bead of simple construction. The glass is porcelain-like in } \\
\text { texture (1700-1836). }\end{array}$ \\
\hline Harris No. 57 & 1 & $\begin{array}{l}\text { Small, brick red, opaque (outer layer), tube-shaped bead of complex construction. Inner layer is translucent } \\
\text { light green. This bead is the type commonly called "Cornaline d'Aleppo." }\end{array}$ \\
\hline Harris No. 61 & 8 & Small, dark Bluebird Blue, translucent, tube-shaped garter bead of simple construction. \\
\hline Harris No. 64 & 2 & Small, white, opaque tube-shaped garter bead of simple construction. \\
\hline Harris No. 66 & 2 & Small, black, opaque, tube-shaped garter bead of simple construction. \\
\hline Harris No. 80 & 13 & Small, Peacock Blue, translucent, donut to barrel-shaped, garter bead of simple construction. \\
\hline Harris No. 96 & 1 & Medium, black, opaque, donut-shaped garter bead of simple construction. \\
\hline Harris No. 138 & 1 & Medium, Peacock Blue, translucent, barrel-shaped garter bead of simple construction. \\
\hline Harris No. 164 & 1 & Medium, dark Bluebird Blue, translucent, barrel-shaped garter bead of simple construction. \\
\hline Glass, no Harris type & 1 & Medium, red, opaque, round necklace bead with raised band around the middle. \\
\hline Jet Beads & 3 & Two are minimally worked, one a little more carefully worked, but all quite crude. \\
\hline Coral Bead & 1 & Made from pink coral. \\
\hline
\end{tabular}

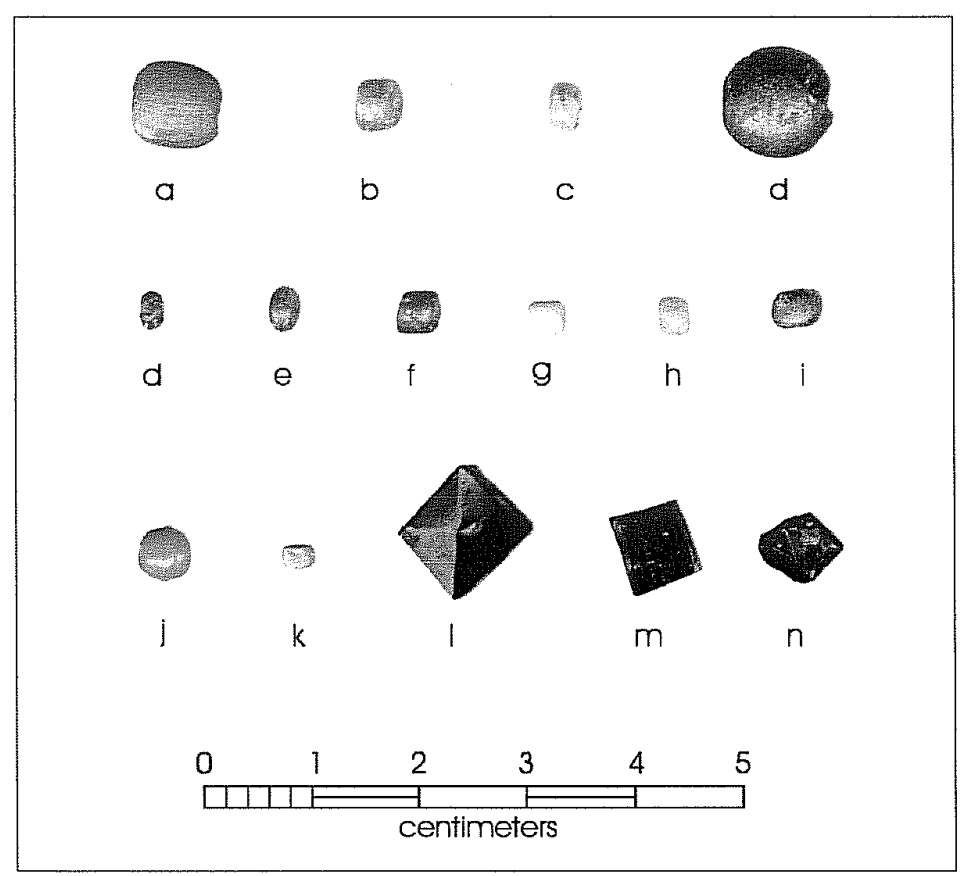

Figure 6-10. Examples of trade beads recovered: a) Harris No. 10; b) Harris No. 18; c) Harris No. 48; d) Harris No. 49; e) Harris No. 50; f) Harris No. 57; g) Harris No. 61; h) Harris No. 64 ; i) Harris No. 66; j) Harris No. 80; k) Harris No. 96; l) Harris No. 138; m) Harris No. 164; n) Red opaque glass bead (no Harris type); o) Coral bead; p-r) Jet beads. 
In addition to the trade beads, two beads made form bird bones were recovered. Beads made from small segments of bird bones are commonly found on Texas mission sites (Ricklis 2000:165; Schuetz 1969:76). One made from a small bird variety came from Level 2 of TU 25 (Figure 6-11a). It is $5 \mathrm{~mm}$ in diameter and $16 \mathrm{~mm}$ long. The other, from Level 7 of TU 34, was made from the bone of a very large bird, being $11 \mathrm{~mm}$ in diameter and $48 \mathrm{~mm}$ long (Figure 6-11b). Both were made by grooving and snapping off the desired length of bone. The ends are polished and there is considerable polish on the shaft.

\section{Jewelry}

Small pieces of copper alloy jewelry with glass sets were brought to the missions as presents for the Indians. Found on most Colonial mission sites, these include finger rings, earrings, and crucifixes (Gilmore 1974:75; Ricklis 2000:85; Schuetz 1969:44).

A finger ring made of copper or brass with a clear glass set was found in Level 3 of TU 3, just outside the gateway (Figure 6-12a). A copper earring consisting of a clear glass set mounted in a circular, flower-shaped setting has a wire brazed to the back for attachment to the ear lobe (Figure 6-12b). This came from Level 2 of TU 17, about $4 \mathrm{~m}$ north of TU 3 and probably within the same midden deposit.

The lower two-thirds of a copper crucifix with five clear glass sets was recovered from Level 2 of TU 25 (Figure

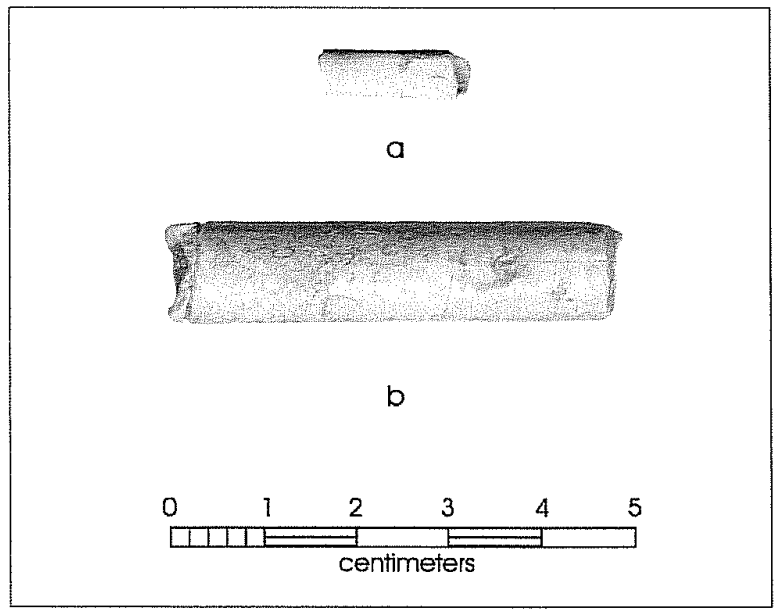

Figure 6-11. Bone beads: a) bead made from a small bird bone; b) bead made from a large bird bone. 6-12c). This unit was about $3 \mathrm{~m}$ south of TU 3 and was within the gateway. This crucifix is similar to others found in mission contexts in South Texas (Meissner 2002:226; Schuetz 1969:45.)

A teardrop-shaped clear glass set in a copper setting appears to once have been part of a larger piece, possibly a crucifix similar to the one that was recovered (Figure 6-12d). This came from the third level in TU 46, which constitutes part of the fill in the pottery kiln.

\section{Clothing Items}

\section{Buttons}

Sixteen buttons were recovered during this project. Most appear to be nineteenth century in origin. They are listed in Table 6-6 and several examples are shown in Figure 6-13.

Three copper buttons with drilled shanks were recovered. One solid cast button from Level 2 of TU 21 has a molded design (Figure 6-13a), and two from Level 3 of TU 26 and Level 1 of TU 37 are the back portions of compound buttons. The first buttons with drilled shanks, popular until about 1830 , were cast in one piece with shanks formed from a protuberance on the back (Albert and Kent 1949:8). Also in use at that time were compound buttons with the back and shank cast in one piece and a convex face usually plain or stamped with a decorative design (Schuetz 1969:47). The other two buttons recovered were backs for this latter type.

Three "pearl" or shell buttons came from TUs 15,17 , and 38. Buttons made of marine shell were imported from England in the first half of the nineteenth century. By the 1890 s, these buttons were made in the U.S. using freshwater mussel shell (Kneupper 1994:80). The shell buttons in this collection appear to be the earlier type, since they are thicker and sturdier than freshwater mussel shell buttons. They are machine made (see Figure 6-13b for an example).

One white porcelain button came from Level 2 of TU 7 (Figure 6-13c). In 1840, Richard Prosser of England patented the process for making these. Kaolin clay powder was pressed into molds that were then fired to produce buttons. Within ten years, most china or porcelain buttons were being made in France and the U.S. (Pool 1987:281). They were very common until after about 1910 when various types of plastic became the most common button material (Albert and Kent 1949:35). 


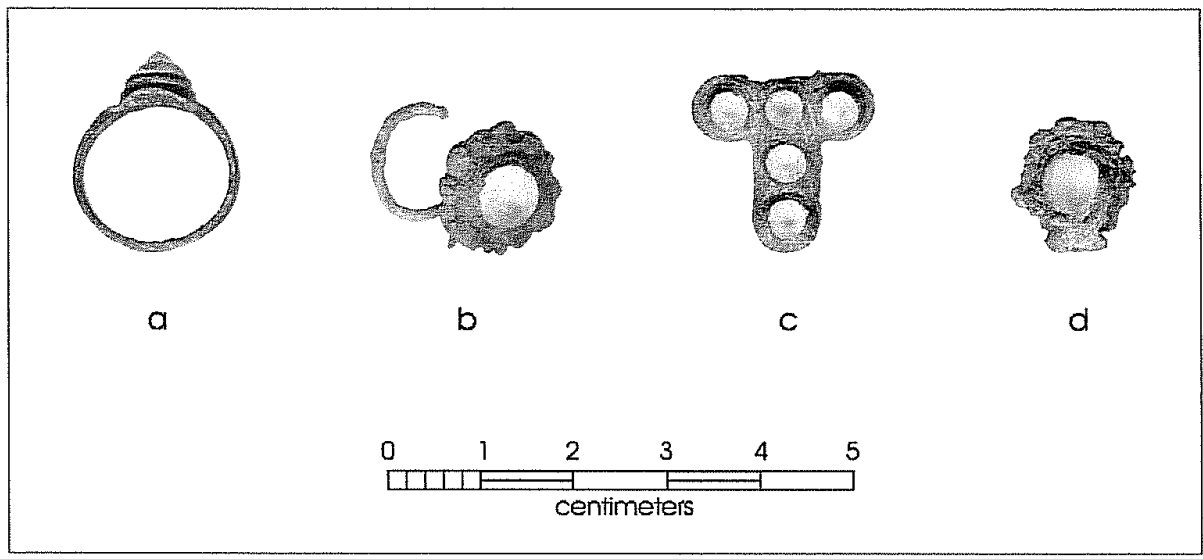

Figure 6-12. Jewelry: a) copper alloy ring with glass jewel; b) copper alloy earring with glass jewel; c) fragment of copper alloy crucifix with glass jewels; d) copper alloy fragment with glass jewel.

Table 6-6. Buttons and Other Clothing Items

\begin{tabular}{|l|c|l|l|c|l|}
\hline \multicolumn{1}{|c|}{ Item } & Ct. & Unit/Level & Composition & Size (mm) & \multicolumn{1}{|c|}{ Description } \\
\hline Button & 1 & TU7/2 & Ceramic & 10.8 & Ceramic "tire" type, four hole. \\
\hline Button & 1 & TU18/1 & Composition & 2.6 & Rounded square, self shank, black. Dated between about 1880 and 1930. \\
\hline Button & 1 & TU9/1 & Composition & 12.3 & $\begin{array}{l}\text { Pale brown with tiny black specks. Two hole. Dated between about 1880 } \\
\text { and 1930 (Meissner 1997:120). }\end{array}$ \\
\hline Button & 1 & TU37/1 & Copper alloy & 11.6 & Back of a compound button. Drilled shank. \\
\hline Button & 1 & TU21/2 & Copper alloy & $12.0 \times 8.8$ & Small button with broken drilled shank. Embossed pattern. \\
\hline Button & 1 & TU26/3 & Copper alloy & 13.8 & Back of a compound button. Drilled shank. \\
\hline Button & 2 & TU15/2 & $\begin{array}{l}\text { Copper alloy } \\
\text { and iron }\end{array}$ & 16.5 & $\begin{array}{l}\text { Overall buttons (stud back), copper alloy faces with iron back. Train } \\
\text { embossed on front. }\end{array}$ \\
\hline Button & 1 & TU15/2 & Copper alloy & 13.5 & $\begin{array}{l}\text { Copper alloy face over iron back. Type usually sold as underwear buttons } \\
\text { until mid-20th century. }\end{array}$ \\
\hline Button & 1 & TU19/1 & Glass & 14.3 & Clear glass two-hole. \\
\hline Button & 1 & TU17/4 & Iron & 17 & Metal overall button (stud back). \\
\hline Button & 2 & TU15/3 & Iron & 15 & Iron alloy hand-snap buttons ("bachelor's buttons"). \\
\hline Button & 1 & TU38/1 & Shell & 10.1 & Machine-made, marine shell, two hole. \\
\hline Button & 1 & TU17/1 & Shell & 10.1 & Machine-made, marine shell, two hole. \\
\hline Button & 1 & TU15/3 & Shell & 10.5 & Machine-made, marine shell, four hole. \\
\hline Shoe heel & 1 & TU42/2 & Leather & & Badly worn. \\
\hline Shoe fragment & 1 & TU12/1 & Leather & & Badly worn. \\
\hline Shoe Eyelet & 1 & TU7/2 & Metal & & \\
\hline Shoe Eyelet & 1 & TU15/2 & Metal & & \\
\hline Shoe Eyelet & 1 & TU26/2 & Metal & & \\
\hline Shoe Eyelet & 1 & TU32/2 & Metal & & \\
\hline Strap fastener & 1 & TU17/4 & Metal & & \\
\hline
\end{tabular}




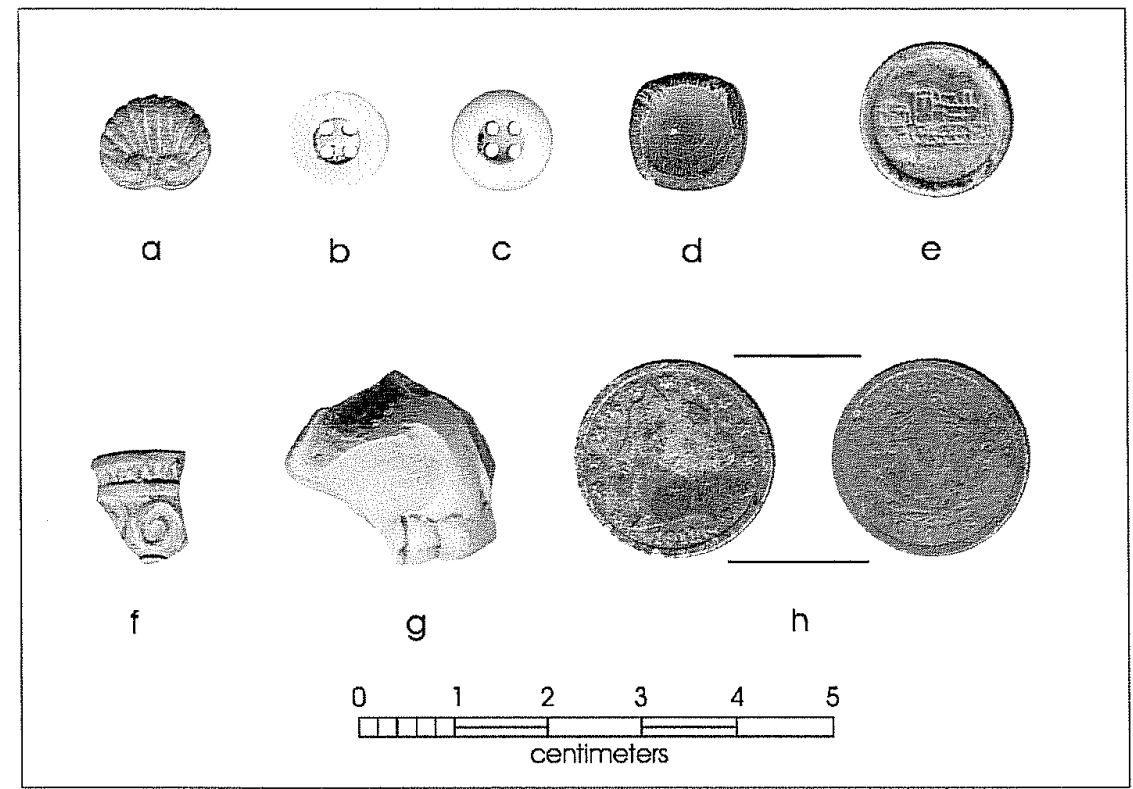

Figure 6-13. Other personal items: a) copper alloy button with drilled shank; b) 4-hole marine shell button; c) ceramic button; d) composition button; e) overall button with embossed train; f) fragment of molded design on clay pipe bowl; g) fragment of clay pipe figurehead; h) U.S. nickel dated 1911.

Two composition buttons are in the collection. The term "composite" refers to buttons that were made of a mixture of substances and molded with holes or self-shank attachments (Pool 1987:286). These buttons were commonly in use from the late nineteenth century until about the time of World War I (Meissner 1997:120). One square, black button with a dish-shaped face and self-shank (Figure 6-13d) came from Level 1 of TU 18. The other, a tan button, came from Level 1 of TU 9.

Two copper overall buttons had a train embossed on them (Figure 6-13e). Similar, though not identical, buttons are dated to 1900-1935 in Hughes and Lester (1991:684).

Two metal buttons are a type called hand snap, also called "bachelor's buttons" because they did not require sewing. The two halves were just snapped together (Israel 1993:320).

Other clothing items recovered included a few shoe parts, an overall strap fastener, and a snap fastener (Table 6-6).

\section{Pipes}

Long stemmed white clay pipes have been made since 1558 in England and are still made today (Ayto 1987). Fragments of clay smoking pipes have been found at other mission sites (Ricklis 2000:80; Schuetz 1969). One white clay pipe stem, from TU $21,7.8 \mathrm{~mm}$ in diameter, with a hole $2.2 \mathrm{~mm}$ in diameter was recovered during the project.

One red clay bowl fragment from TU 22 has part of a design (Figure 6-13f) that is similar to pipes made in Ohio in the late-nineteenth and early-twentieth centuries (Sudbury 1979:182, Plate 13). Another red clay bowl fragment, from TU 1, has part of a figurine (Figure 6-13g). Such pipes were popular in the late-nineteenth and early-twentieth centuries. The portion of the pipe's visible interior does not look as if the pipe was ever used. 


\section{Other Personal Items}

Three U.S. coins were recovered during the excavations. A 1911 nickel came from Level 1 of TU 22 just north of the gateway (Figure 6-13h). A 1942 penny and a 1984 penny were found in the fill of the pottery kiln, in Level 2 of TU 32 and Level 1 of TU 46, respectively. A small gear from a wristwatch mechanism came from Level 3 of TU 17. A piece of a contemporary hair brush that consists of a plastic back and plastic bristles was found in Level 1 of TU 7.

\section{Activities}

Artifacts in this class include toys, items related to various games, writing materials, etc. Four toys were identified. The most interesting was a piece of blackboard slate, recovered in Level 2 of TU 47, that has been chipped into a shape resembling an arrow point (Figure 6-14). Slate is far too brittle to use as an actual projectile point, but this item was almost certainly a toy. The other toys recovered were a metal toy car, in a style reminiscent of the late 1970 s, and a fragment of a porcelain doll's dish. The latter is probably from the late-nineteenth to early-twentieth centuries.

Five other pieces of blackboard slate were identified in the collection. In addition, two pieces of the graphite "lead" of a pencil, and three ferrules (i.e., the metal band that hold erasers on a pencil), were recovered.

\section{Arms}

There were very few artifacts in this class, but they represent the entire period of mission occupation. They are described in Table 6-7. Of particular interest is the arrow point made on a piece of copper alloy sheeting (Figure 6-15a), from TU 18, Level 2. The base was made by folding a section of

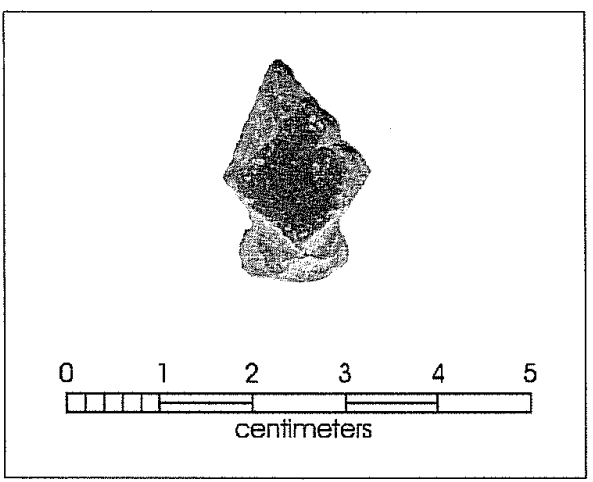

Figure 6-14. Slate "arrow point."

the copper, but the rest of the shaping seems to have been cut out of a larger piece of metal. Metal points are not uncommon in Colonial and other late-eighteenth- and earlynineteenth-century sites (Tomka 2002:232). As is usually the case with metal points in Texas, this point has no barbs (Tomka 2002:232).

There were two lead balls recovered during the excavations (Table 6-7). One is probably a musket ball, approximately $18 \mathrm{~mm}$ in diameter, with a dent on one side that may represent an impact (Figure 6-15b). The other is smaller, about 13 $\mathrm{mm}$ in diameter, and was probably intended for a pistol (Figure 6-15c).

The most interesting of the three cartridges recovered is a .38 caliber center-fired round (Figure 6-15d). The $.38 \mathrm{~S} \&$ W was introduced in the late 1870 s and used mostly by police forces. It's popularity began to fade after 1902 (Hawks 2002). Weapons that fired this round were made by many companies. This cartridge was made by the Winchester Repeating Arms Company. This cartridge has been fired.

Table 6-7. Arms-related Artifacts

\begin{tabular}{|c|c|l|}
\hline Unit & Lev. & \multicolumn{1}{|c|}{ Description } \\
\hline 18 & 2 & Copper alloy point. Shank was made by bending and flattening metal. \\
\hline 18 & 3 & Musket ball, lead, $18 \mathrm{~mm}$. One side is slightly flattened, suggesting an impact. \\
\hline 32 & 4 & Musket or pistol ball, $13 \mathrm{~mm}$. \\
\hline 31 & 3 & .38 caliber Center-fired cartridge. Headmark: "WRA Co/38 S \& W". \\
\hline 8 & 3 & 10 gauge brass shotgun casing. Headmark: "ELEY BRO/10/LONDON". \\
\hline 23 & 1 & .22 short rimfire cartridge. Headmark: " $\mathrm{H}$ ". Made by the Winchester Repeating Arms Company. \\
\hline 42 & 2 & .22 short cartridge, flattened. Has been fired. No headmark. \\
\hline 43 & 1 & .177 caliber pellet for air gun. \\
\hline
\end{tabular}




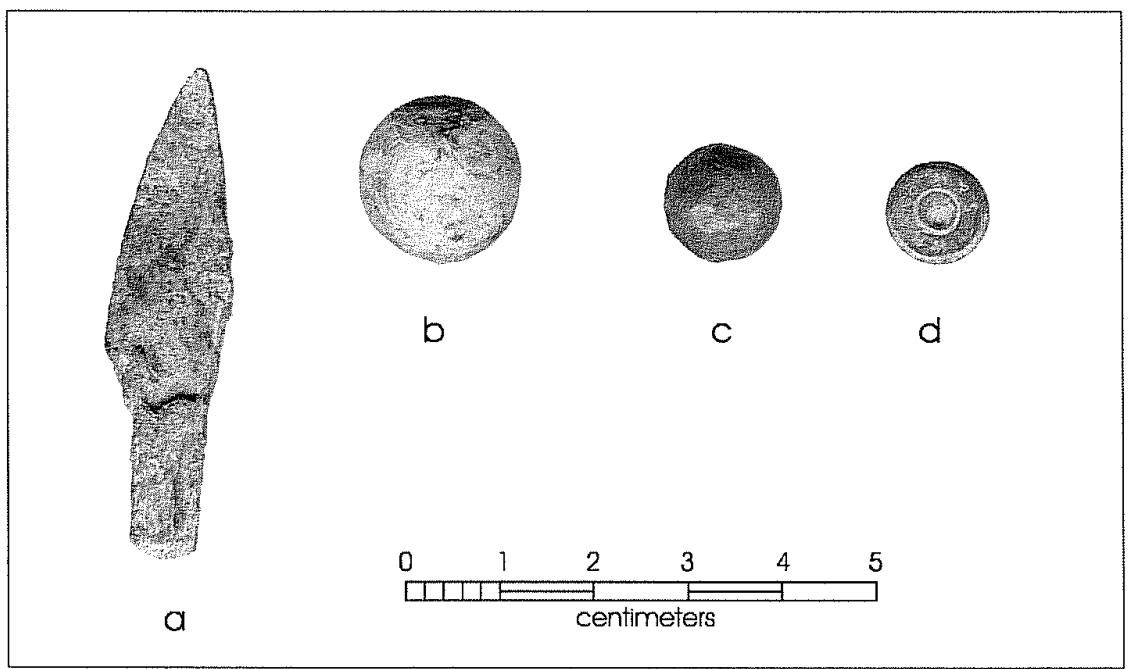

Figure 6-15. Arms-related artifacts: a) copper alloy arrow point; b-c) lead musket balls; d) .38 caliber cartridge.

\section{Construction}

There were 1,156 construction-related artifacts recovered during this project. The categories of construction items and their counts are shown in Table 6-8.

Table 6-8. Construction-related Artifacts

\begin{tabular}{|c|c|}
\hline Construction Artifacts & Count \\
\hline Cut Nails & 57 \\
\hline Wire Nails & 152 \\
\hline Other nails and tacks & 8 \\
\hline Screws & 7 \\
\hline Nuts \& Bolts & 4 \\
\hline Other Hardware & 12 \\
\hline Brick, Tile & 365 \\
\hline Mortar & 179 \\
\hline Plaster & 13 \\
\hline Window glass & 284 \\
\hline Asphalt & 66 \\
\hline Concrete & 3 \\
\hline Electrical items & 6 \\
\hline Total & 1156 \\
\hline
\end{tabular}

The change in the manufacture of nails just before the end of the nineteenth century provides a useful dating method. Wire nails were a tiny fraction of nail production in 1880 , but by 1890 , half of all nails were wire, and ten years later they made up about $85 \%$ of all nails manufactured (Adams 2002:72).

One item of particular interest is a decorative copper plate used to construct doors during the Colonial period. This artifact, known in Spanish as a chapatone, is clearly hand made (Figure 6-16).

\section{Barn/Workshop}

Artifacts in this class $(n=99)$ include horse-related items, machinery parts, fencing and other wire (except insulated electrical wire) and similar items. They are presented in Table 6-9.

\section{Miscellaneous}

This class includes metal items not placed in other categories, such as unidentified metal objects and metal scrap, and other miscellaneous items. They are listed in Table 6-10. 


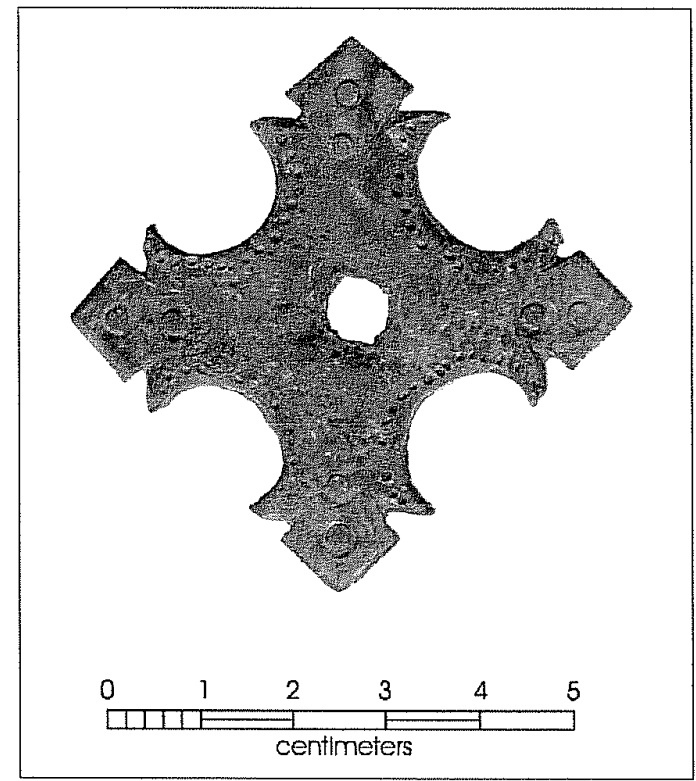

Figure 6-16. Copper alloy chapatone.
Table 6-9. Artifacts from Bam/Workshop

\begin{tabular}{|l|r|}
\hline \multicolumn{1}{|c|}{ Artifact } & Count \\
\hline Horseshoe nails & 1 \\
\hline Other horse tack & 1 \\
\hline Rubber tire fragments & 8 \\
\hline Machinery Parts & 4 \\
\hline Fencing staples & 5 \\
\hline Wire & 80 \\
\hline & 99 \\
\hline
\end{tabular}

Table 6-10. Metal and Miscellaneous Artifacts

\begin{tabular}{|l|r|}
\hline \multicolumn{1}{|c|}{ Artifact } & \multicolumn{1}{c|}{ Comnt } \\
\hline Unidentified Metal Objects & 36 \\
\hline Metal Scrap & 913 \\
\hline Burned clay & 492 \\
\hline Cedar post fragments & 16 \\
\hline Other wood fragments & 63 \\
\hline Charcoal & 57 \\
\hline Coal slag & 9 \\
\hline Melted glaze & 1 \\
\hline Plastic & 48 \\
\hline Unidentified items & 4 \\
\hline & 1639 \\
\hline
\end{tabular}

tip is not enough to confirm this (Figure 6-17, $\mathrm{k}-1$ ). The breaks on two of the proximal fragments can be identified as manufacture breaks, another is likely a use break and all others are indeterminate (Table 6-11). Of the confirmed Guerrero points, two are in the proportionally shorter, broader triangular form and eight favor the proportionally longer, narrower lanceolate form.

\section{Bifaces}

The five bifaces present (Table 6-11) were likely intended for arrow point production. Three of the bifaces are complete but are only in the second stage of reduction. A stage 2 biface has had flakes removed from all edges but is not thinned or necessarily symmetrical (Andrefsky 1998:180-183). At this stage of reduction a biface is not committed to becoming a particular tool; however, the stage 2 bifaces recovered from the test units are flaked enough to identify proximal and distal ends and are of the right size to produce arrow points after further reduction (Figure 6-17, $\mathrm{m}-0$ ). There were two stage 3 bifaces recovered (Table 6-11). Stage 3 bifaces are defined as well-edged, thinned and essentially symmetrical (Andrefsky 1998:180-182). The two analyzed here may be arrow point blanks but manufacture breaks occurred on each halting further reduction (Figure 6-17, p-q). 


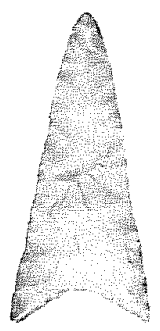

a

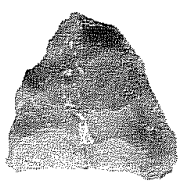

g

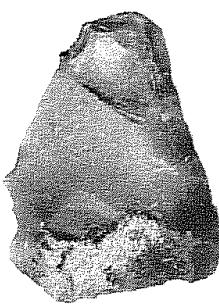

$\mathrm{m}$

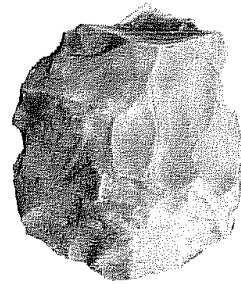

q

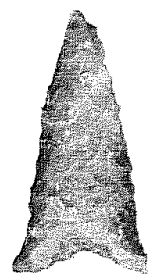

b

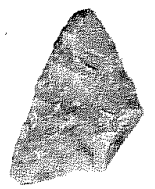

h

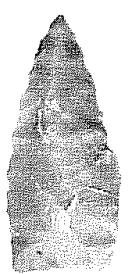

$\mathrm{c}$
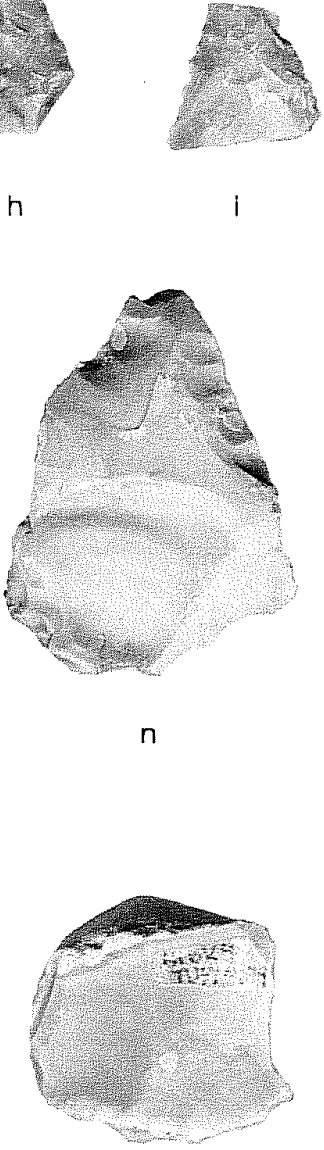

r
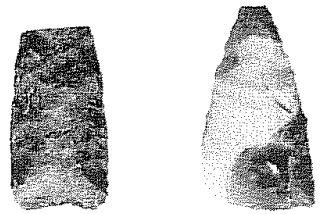

e
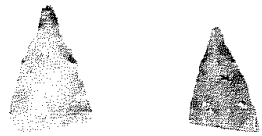

k

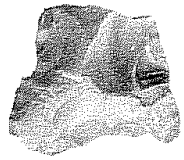

$\mathrm{p}$
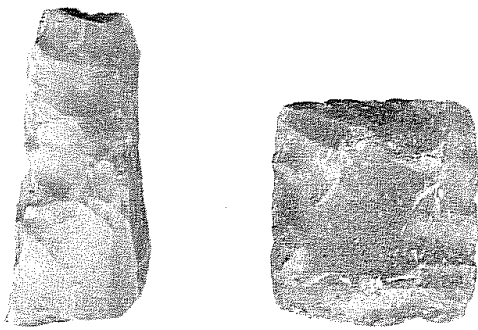

$\dagger$

\section{\begin{tabular}{llllll}
0 & 1 & 2 & 3 & 4 & 5 \\
\hline CIII & $=$
\end{tabular}}

Figure 6-17. Lithic tools: $\mathrm{a}-\mathrm{g}$ ) Guerrero points; $\mathrm{h}-\mathrm{j}$ ) Guerrero point fragments; $\mathrm{k}-1$ ) unknown point fragments; $m-n$ ) stage 2 bifaces; 0 ) stage 2 biface fragment; $p-q$ ) stage 3 bifaces; $t-s$ ) expedient unifaces; $t$ ) gunflint. 
Table 6-11. Data from Lithic Tools

\begin{tabular}{|c|c|c|c|c|c|c|c|}
\hline \multirow[b]{2}{*}{ Unit } & \multirow[b]{2}{*}{ Level (cm) } & \multirow[b]{2}{*}{ Cat\# } & \multirow[b]{2}{*}{ Tool Type } & \multicolumn{3}{|c|}{ Max. Dimensions (mm) } & \multirow[b]{2}{*}{ Blank } \\
\hline & & & & Length & Width & Thick & \\
\hline & & & Arrow Points & & & & \\
\hline 5 & $3(20-30)$ & 034-007 & Guerrero Arrow Point, proximal & & 18 & 3 & flake blank \\
\hline 5 & $3(20-30)$ & 034-006 & Guerrero Arrow Point, proximal & & & 4 & indeterminate \\
\hline 17 & $4(30-40)$ & $115-006$ & Guerrero Arrow Point, complete & 37 & 17 & 3 & indeterminate \\
\hline 19 & $3(20-30)$ & $145-006$ & Indeterminate distal fragment & & & 3 & indeterminate \\
\hline 22 & $4(30-40)$ & $156-005$ & Guerrero Arrow point, complete & 31 & 14 & 4 & flake blank \\
\hline 22 & $4(30-40)$ & $156-006$ & Guerrero Arrow Point, proximal & & 14 & 3 & indeterminate \\
\hline 22 & $4(30-40)$ & $156-007$ & Guerrero Arrow Point, complete & 25 & 13 & 2 & flake blank \\
\hline 29 & $1(0-10)$ & $211-013$ & Guerrero Arrow point, complete & 17 & 20 & 5 & indeterminate \\
\hline 30 & $1(0-10)$ & $212-010$ & Indeterminate distal fragment & & & 2 & indeterminate \\
\hline 32 & $3(20-30)$ & 236-008 & Guerrero Arrow Point, complete & 32 & 16 & 4 & flake blank \\
\hline 42 & $2(10-20)$ & $301-008$ & Guerrero Arrow Point, proximal & & 11 & 4 & indeterminate \\
\hline \multirow[t]{2}{*}{47} & $2(10-20)$ & $326-006$ & Guerrero Arrow Point, broken ear & 22 & & 4 & indeterminate \\
\hline & & & Bifaces/Point Preforms & & & & \\
\hline 17 & $4(30-40)$ & $115-007$ & Biface, stage 2, complete & 34 & 25 & 7 & secondary flake \\
\hline 17 & $3(20-30)$ & $110-012$ & Biface, stage 2, complete & 48 & 35 & 9 & secondary flake \\
\hline 21 & $2(10-20)$ & $132-007$ & Biface, stage 3, proximal & & & 5 & indeterminate \\
\hline 26 & $3(20-30)$ & 199-011 & Biface, stage 3, proximal & & 27 & 8 & secondary flake \\
\hline \multirow[t]{2}{*}{34} & $8(70-80)$ & $261-003$ & Biface, stage 2, complete & & & & secondary flake \\
\hline & & & Unifaces & & & & \\
\hline 18 & $3(20-30)$ & $173-005$ & Uniface, indeterminate, heavily damaged & & & & indeterminate \\
\hline \multirow[t]{2}{*}{37} & $2(10-20)$ & $279-011$ & Uniface, expedient scraper & 34 & 34 & 21 & worked pebble \\
\hline & & & Gunflints & & & & \\
\hline 26 & $3(20-30)$ & 199-012 & Bifacially worked on all edges, no wear & 27 & 25 & 6 & flake blank \\
\hline
\end{tabular}

\section{Unifaces}

Two unifaces are present in the assemblage (Table 6-11). The first is a small expedient hide scraper made from a pebble or a piece of angular debris (shatter) and would be held between the thumb and forefinger (Figure 6-17r). This type of scraper is common to the missions (Tomka and Fox 1999:38). The second uniface has a 37-mm-long worked edge with step fractures and polish identifying this artifact as a utilized uniface (Figure 6-17s). The length of the worked edge is cut short by breakage and all other surfaces seem to have been pulverized beyond recognition. Considering the form and size of the remaining working edge, this uniface was probably a scraper, larger than the expedient scraper. As with the stage 2 bifaces and the distal projectile point fragments, due to damage the function of the second uniface as a scraper is only supposition.

\section{Gunflints}

The single gunflint recovered is very formal (Figure 6-17t). Made from a flake, it is bifacially worked, rectangular and well-thinned (Table 6-11). The basic shape and bifacial working fit the description of gunflints found at other missions (Fox 1979:28). There are no traces of the bulb of percussion and all cortex has been removed. There is no crushing of the edges and no step fractures are present. No polish is present and there are no signs of retouch. Every indication is that this well-crafted gunflint was never used.

\section{Cores}

The seven cores recovered are in three forms: pebble cores, unidirectional cores and bidirectional removal cores. The pebble cores are the most common $(n=4)$ and all are chert. These cores are smaller, with generally fewer flake removal scars (Table 6-12). 
Table 6-12. Data from Lithic Cores

\begin{tabular}{|c|l|l|l|c|c|c|c|}
\hline \multirow{2}{*}{ Unit } & & & & \multicolumn{3}{|c|}{ Maximum Dimensions (mm) } & \multirow{2}{*}{$\begin{array}{c}\text { Number of } \\
\text { Revel (cm) }\end{array}$} \\
\cline { 5 - 7 } & Cat\# & Core Type & Length & Width & Thickness & Remal Scars \\
\hline 4 & $2(10-20)$ & $036-007$ & unidirectional & 67 & 67 & 25 & 4 \\
\hline 25 & $2(10-20)$ & $189-014$ & pebble core & 55 & 42 & 27 & 1 \\
\hline 34 & $7(60-70)$ & $258-008$ & bidirectional & 65 & 51 & 13 & 13 \\
\hline 35 & $2(10-20)$ & $272-005$ & unidirectional & 123 & 84 & 71 & 15 \\
\hline 1 & $1(0-10)$ & $035-002$ & pebble core & 50 & 35 & 22 & 3 \\
\hline 13 & $3(20-30)$ & $013-002$ & pebble core & 47 & 38 & 21 & 6 \\
\hline 13 & $3(20-30)$ & $013-003$ & pebble core & 62 & 53 & 16 & 2 \\
\hline
\end{tabular}

The only bidirectional core has two platforms. From one platform, the flakes were removed along the length, from the other, removals were through the thickness of the core.

The smaller of the two unidirectional cores is somewhat tabular in shape having flakes removed from one side only. The second unidirectional core, at $123 \mathrm{~mm}$ long, is the largest core in the assemblage. It has the most flake removal scars and is the only core recovered made of quartzite rather than chert. Despite the number of removals taken from this core, there are no quartzite tools and only three quartzite lithics among the 799 unmodified pieces of debitage.

The chert cores are essentially "exhausted" indicating their maximized exploitation as a resource. The quartzite core still has surface available for the removal of good-sized flakes. The cause of its discontinued use is unknown.

\section{Unmodified Debitage}

Test unit excavations recovered a total of 799 pieces of unmodified debitage providing a decent sample size for analysis. The debitage was examined for amount of cortex, size, facet count, and type/morphology.

Cortex examination showed primary flakes to be the least common at $5.9 \%(n=47)$. There is then a sharp jump in the number of secondary flakes to $40.2 \%(n=321)$ with a lesser increase in the number of tertiary flakes $(n=431$; Figure 6-18). This pattern reflects typical core reduction.

Debitage size recovery favors the 11-20 mm size range at $53.3 \%(\mathrm{n}=426)$ with a sharp drop off to the next most numerous size category, 21-30 $\mathrm{mm}$ (Figure 6-19). The counts decrease gradually from sizes $21-30 \mathrm{~mm}$ through $61-70 \mathrm{~mm}$. As with most excavations, the use of $1 / 4$-inch screen has resulted in a very low recovery of debitage in the 1-10 mm size range, as a result, representation of this size class has been artificially reduced. While the size patterns are similar to those found at other mission sites (Tomka and Fox 1999:37) there are three additional size ranges represented in this assemblage (Figure 6-19). There is one flake each in the 71-80 mm size, the 101-110 $\mathrm{mm}$ size, and the $301-310 \mathrm{~mm}$ size range. Two are core preparation flakes and one is a core reduction flake. One was recovered in Level $3(20-30 \mathrm{~cm})$ and two in Level $4(30-40 \mathrm{~cm})$. At one flake each, these large size classes each represent a minuscule amount $(0.1 \%)$ of the total unmodified debitage count.

In the category of platform facet counts, the largest classification was the $\mathrm{n} / \mathrm{a}$ or not available class. A facet count was considered $\mathrm{n} / \mathrm{a}$ when the platform was gone or damaged. Excluding the $n /$ a grouping ( $n=548$ ), the largest class was single facet platforms $(\mathrm{n}=198)$ with corticate platforms $(\mathrm{n}=36)$ a distant second (Figure 6-20). Few in number are the two facets $(n=11)$ and three or more facets $(n=6)$ platform classes. These flakes are seen as being the results of bifacial reduction (Andrefsky 1998:89-90,118).

Flake typing divides the debitage into nine classes: biface manufacture, biface thinning, core preparation, core reduction, platform preparation, blades, uniface manufacture, angular debris, and indeterminate. As a group, core preparation and platform preparation flakes both result from the same reduction goal, to work the core to a condition where a desired size and shape of flake may be struck off. To this end, they are grouped into one class for comparison. As one group, core and platform preparation flakes account for $37.1 \%(\mathrm{n}=296)$ of the debitage and are the largest class (Figure 6-21). The next largest grouping is the indeterminate classification. Indeterminate flakes were either damaged, and so lack diagnostic features, or share features of two or more flake types. Numbers drop dramatically to the next 


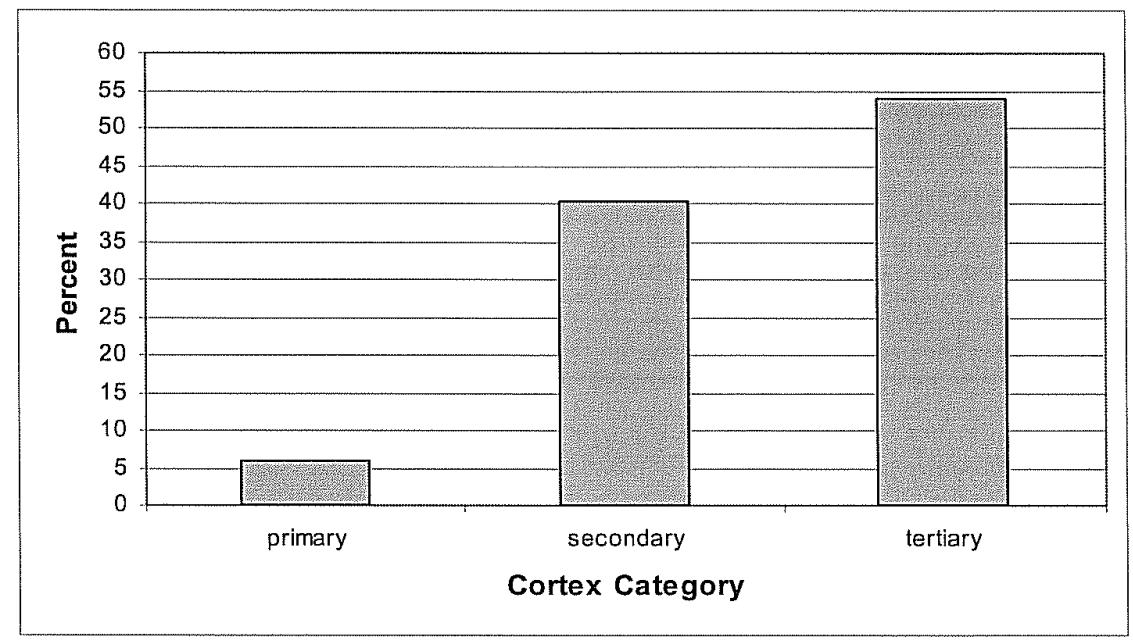

Figure 6 18. Distribution of debitage by cortex categories.

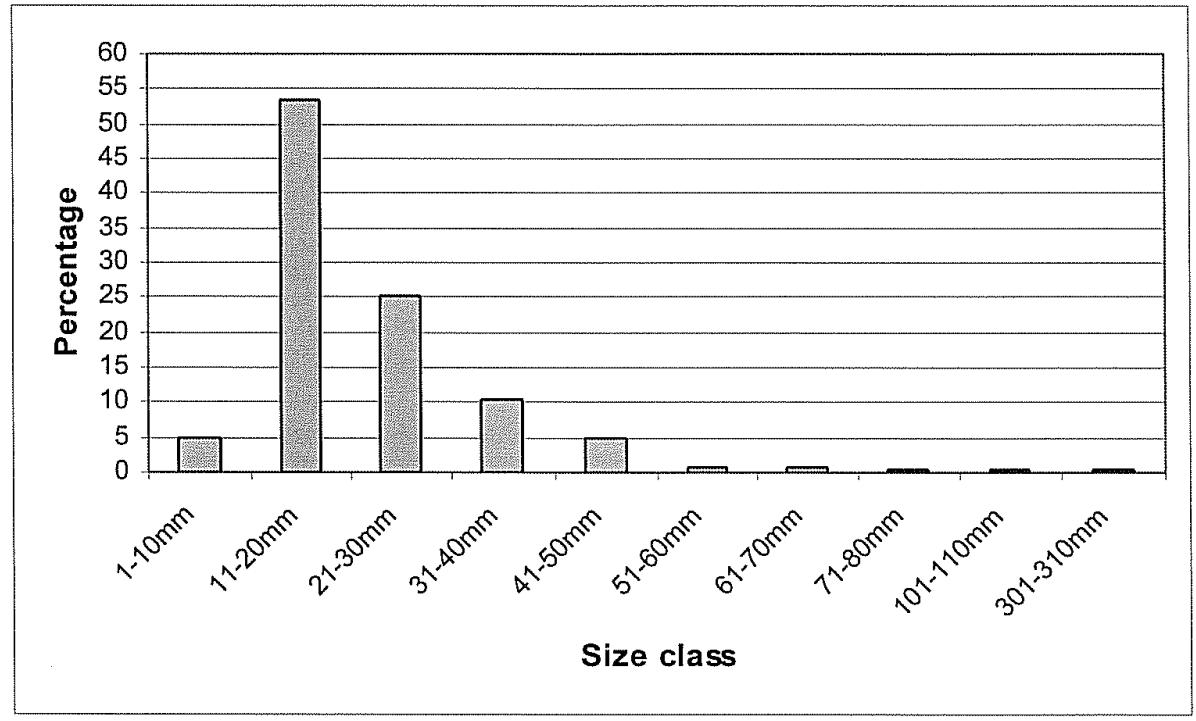

Figure 6-19. Distribution of debitage by size.

class which is angular debris, followed by biface thinning flakes, core reduction flakes, biface manufacture flakes, uniface manufacture flakes, and lastly, blade fragments (Figure 6-21). The core and platform preparation flakes, along with the core reduction and uniface manufacture flakes, overwhelmingly have single facet platforms indicating most reduction was off unidirectional and bidirectional cores rather than bifacial cores. This is supported by the recovery of unidirectional and bidirectional cores and no bifacial cores. All of this suggests a greater emphasis on production of unifaces and expedient tools rather than bifacial tools (Tomka et al. 1999:33-34). As is shown by the presence of Guerrero points and small, rough bifaces, there was some bifacial working. This is further demonstrated by the presence of a small number of biface manufacture and biface thinning flakes (Figure 6-21). 


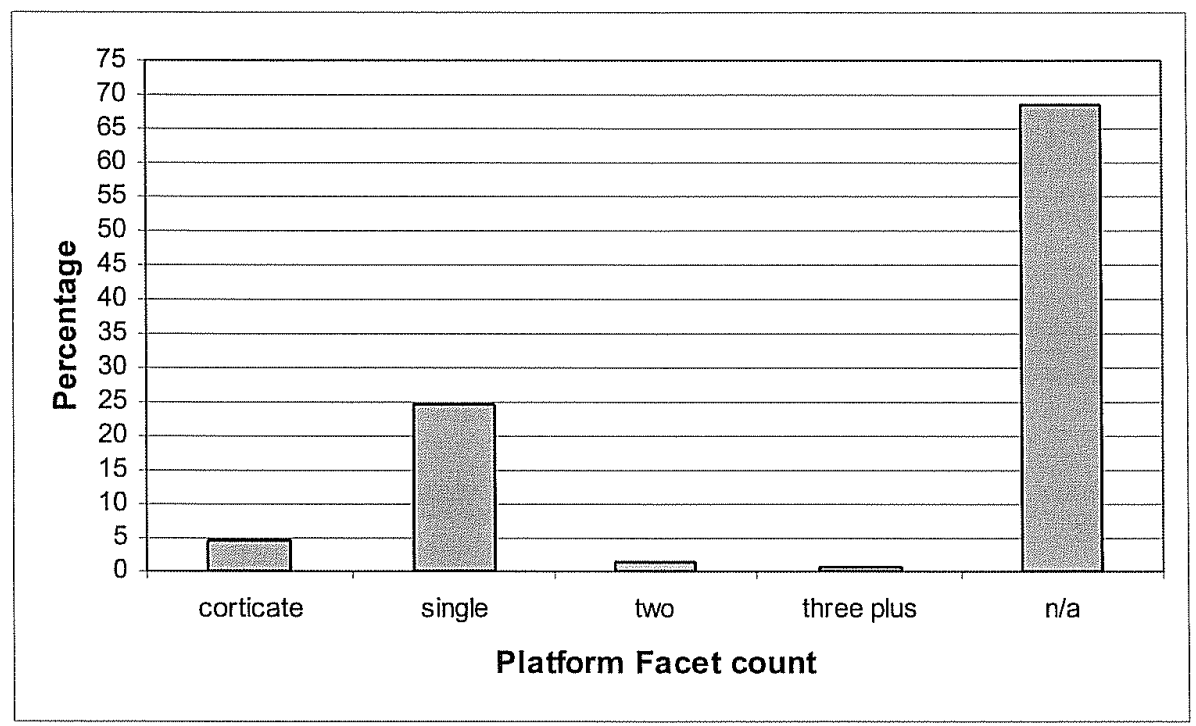

Figure 6-20. Distribution of platform-bearing flakes by facet counts.

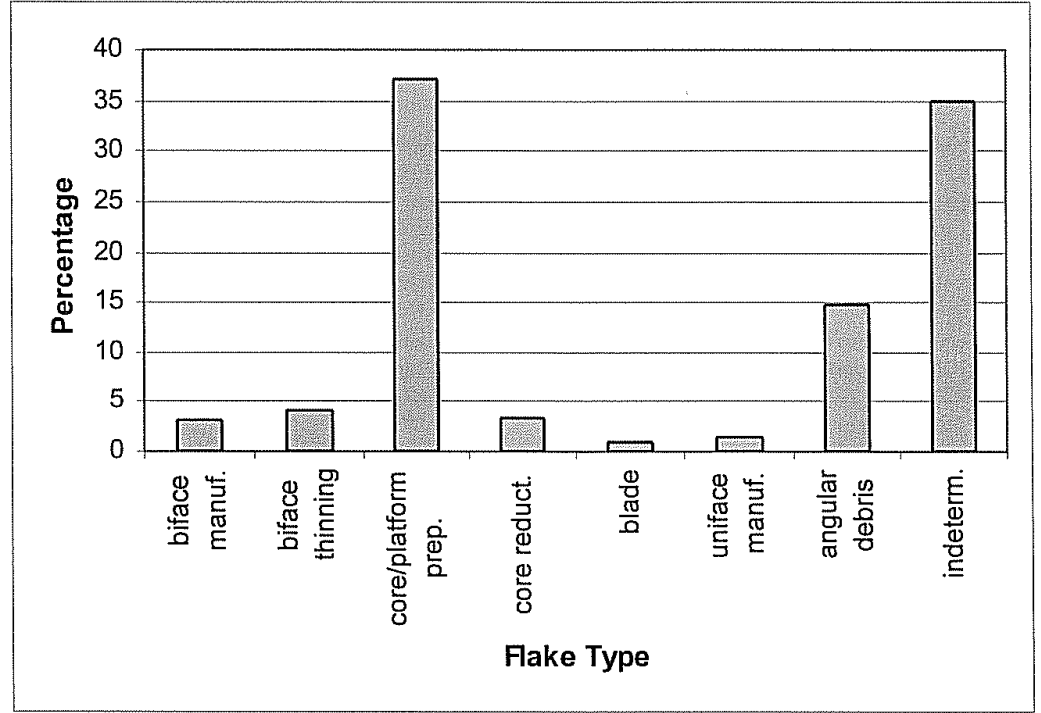

Figure 6-21. Distribution of debitage by flake type. 


\section{Lithics Overview}

The lithics from Mission Espada are made from knappable materials procured from the gravels of the San Antonio River. The large flakes found at Espada may indicate the availability of larger chert cobbles along the nearby section of river. Another explanation may be that unmodified flakes this large have not been recorded at other missions due to their rarity and the small sample size of recovered lithics. A large sample of over 2,000 mission lithics has been analyzed in Fox (1979), but as size was not a focus for the unmodified debitage, no size ranges were reported for comparison.

The tool forms recovered are of a limited variety. There is one gunflint, one "thumbnail" scraper, one other possible scraper, 12 arrow points, and five rough bifaces. The small size of the bifaces (27-48 mm long) and of the arrow points (17-37 mm long), combined with the small size of the biface manufacture and thinning flakes $(9-45 \mathrm{~mm}$ with $65 \%$ below $20 \mathrm{~mm}$ ), indicates a focus on the production of small bifaces. As stated earlier, the cores, facet counts, and remaining unmodified debitage show the dominance of unifacial and expedient tool production.

This pattern in tool forms has been noted at other missions. The increase in expedient tools, like the thumbnail scraper, seems to reflect a more sedentary lifestyle (Tomka and Fox 1999:38). The lack of many bifacial stone tool forms is interpreted as replacement of these forms with metal tools. A specific example is the replacement of stone knives by metal knives (Tomka and Fox 1998:33). The advantage of a metal knife is clear. Metal knives last many years and hold an edge far longer than a stone knife. After initial investment, the metal knife would be a highly effective, low maintenance tool, therefore of economic benefit. Chert, for the production of stone arrow points, was both free and abundant from the river banks at mission locations. In the hands of persons skilled in lithic technology, they were quickly made. A copper point was found during this project (see Figure 6-15a). This arrow point of thin, relatively soft metal could just as easily be damaged from use as would a chert point. Unlike metal knives, metal arrows are not always clearly superior in their performance, they cost more than stone points and were less abundant. Metal arrow points were not economically viable replacements for stone arrow points. In essence, the lithics at Mission Espada demonstrate the most advantageous selection involved in the adoption of European technologies by American peoples.

\section{Vertebrate Faunal Remains}

\author{
Barbara A. Meissner
}

A total of 22,092 vertebrate faunal remains, weighing $28,970.82$ grams, was recovered during the project. A list of taxa identified for all bone is shown in Table 6-13. A complete provenienced list of all data acquired from the bones is on file at CAR and is available upon request.

\section{Methods}

In the field, all bone was recovered by dry screening matrix through $1 / 4$-inch mesh. Bones were bagged with other artifacts by unit and level. In the laboratory, all bone was washed, air-dried, and bagged by unit and level. The bone was identified to the most specific taxon possible using the comparative collection at $\mathrm{CAR}$, as well as several reference texts (Balkwill and Cumbaa 1992; Boessneck 1970; Cohen and Serjeantson 1996; Gilbert 1990; Hildebrand 1955; Hillson 1986; Olsen 1960, 1964, 1968; Schmid 1972; Sobolik and Steele 1996). Identifications were conservative, i.e., bone that appeared to be cow-sized was not identified as Bos taurus unless it could be differentiated from Bison and Equus species. All bone was weighed. Evidence of exposure to heat was noted on all bone. Element, portion of element, side, evidence of immaturity, butcher marks, and pathologies were noted on bone identified to the order taxonomic level. When bone could be identified only to class (e.g., mammal, bird, etc.), an estimate of the size of the animal was made when possible. After the analysis, the bone was bagged by unit and level. Bone identified to at least the order taxonomic level was bagged separately and included in the unit-level bags.

Before beginning an analysis of vertebrate faunal remains, consideration must be given to the fact that badly fragmented bone is usually unidentifiable, and is thus "analytically absent" (Lyman and O'Brien 1987). Small bones are more likely to be rendered unidentifiable by non-cultural taphonomic factors (Von Endt and Ortner 1984), while large bones, especially those of such animals as cattle, may be more likely to be processed to extract bone grease, leaving the majority of the bone unidentifiable (Vehik 1977). The degree to which any of these factors has affected the collection cannot usually be assessed. 
Table 6-13. Taxa Identified

\begin{tabular}{|c|c|c|c|}
\hline Taxa & Common Name & Count & Weight (g) \\
\hline \multicolumn{4}{|c|}{ Mammals } \\
\hline Artiodactyl & Deer, sheep, goats & 163 & 582.97 \\
\hline Bos taurus & Cattle & 106 & $3,442.96$ \\
\hline Bovinae & Cattle or bison & 167 & $2,181.64$ \\
\hline Canis sp. & Dog, wolf, or coyote & 12 & 25.70 \\
\hline Canis latrans & Coyote & 2 & 3.02 \\
\hline Capra hircus & Domestic goat & 8 & 33.56 \\
\hline Capra/Ovis & Goat or sheep & 28 & 126.74 \\
\hline Carnivora & Carnivore & 6 & 1.97 \\
\hline Conepatus mesoleucus & Hog-nosed skunk & 3 & 3.20 \\
\hline Dasypous novemcintus & Armadillo & 2 & 0.41 \\
\hline Didelphis virginiana & Opossum & 51 & 38.54 \\
\hline Equus sp. & Horse family & \begin{tabular}{l|l|}
36 \\
\end{tabular} & 370.13 \\
\hline Felis domesticus & Domestic cat & 6 & 11.31 \\
\hline Lepus californicus & Blacktailed jackrabbit & 6 & 3.95 \\
\hline cf. Lynx rufus & Bobcat & 2 & 4.54 \\
\hline Mephitis mephitis & Stripped skunk & 1 & 0.30 \\
\hline Neotoma sp. & Woodrats & 161 & 46.32 \\
\hline Odocoileus virginianus & White-tailed deer & 76 & 535.98 \\
\hline Ovis aries & Domestic sheep & 26 & 152.64 \\
\hline Pecari tajacu & Javelina, collared peccary & 24 & 114.99 \\
\hline Procyon lotor & Raccoon & 3 & 3.39 \\
\hline Rodentia & Rodents & 148 & 26.86 \\
\hline Sciurus sp. & Tree squirrels & 4 & 1.83 \\
\hline Sigmodon hispidus & Cotton rat & 18 & 3.51 \\
\hline Sus scrofa & Domestic pig & 30 & 70.47 \\
\hline Sylvilagus sp. & Cottontail rabbit & 25 & 9.41 \\
\hline Mammal--very small & Mice, rat-sized & 57 & 6.77 \\
\hline Mammal--small & Rabbit-sized & 44 & 17.16 \\
\hline Mammal--medium & Dog-sized & 54 & 37.19 \\
\hline Mammal--large & Deer, sheep-sized & 364 & 851.16 \\
\hline Mammal--very large & Cattle, bison, horse-sized & 2,069 & $10,230.66$ \\
\hline \multirow[t]{2}{*}{ Mammal } & Size indeterminate & 17,865 & $9,686.16$ \\
\hline & Total Mammals & 21,567 & $28,625.44$ \\
\hline \multicolumn{4}{|c|}{ Birds } \\
\hline Anas sp. & Ducks & 6 & 2.18 \\
\hline Anser/Branta & Geese & 11 & 7.06 \\
\hline Gallus domesticus & Chicken & 18 & 12.32 \\
\hline Meleagris gallopavo & Turkey & 9 & 9.82 \\
\hline Aves--medium & Pigeon-sized & 10 & 1.90 \\
\hline Aves--large & Chicken-sized & 7 & 6.41 \\
\hline Aves--very large & Turkey, hawk-sized & 13 & 17.69 \\
\hline \multirow[t]{2}{*}{ Aves } & Size indeterminate & 149 & 61.32 \\
\hline & Total Birds & 223 & 118.70 \\
\hline
\end{tabular}


Table 6-13. continued...

\begin{tabular}{|c|c|c|c|}
\hline Taxa & Common Name & Count & Weight $(\mathrm{g})$ \\
\hline \multicolumn{4}{|c|}{ Reptiles } \\
\hline Chelydra serpentina & Snapping turtle & 1 & 0.73 \\
\hline Crotalus sp. & Rattlesnakes & 2 & 0.51 \\
\hline Pseudomys sp. & Pond sliders & 3 & 3.88 \\
\hline Terrepene sp. & Box turtles & 10 & 8.82 \\
\hline Trionyx $x$ sp. & Softshelled turtles & 35 & 112.43 \\
\hline \multirow[t]{2}{*}{ Testudinata } & Turtles & 25 & 20.42 \\
\hline & Total Reptiles & 76 & 146.79 \\
\hline \multicolumn{4}{|c|}{ Amphibians } \\
\hline \multirow[t]{2}{*}{ Rana sp. } & Frogs & 1 & 0.19 \\
\hline & Total Amphibians & 1 & 0.19 \\
\hline \multicolumn{4}{|c|}{ Boney Fishes } \\
\hline Aplodinotus grunniens & Freshwater drum & 2 & 1.21 \\
\hline \begin{tabular}{|l} 
Ictalurus $\mathrm{sp}$. \\
\end{tabular} & Catfish & 25 & 11.73 \\
\hline Lepisosteus sp. & Gars & 3 & 0.65 \\
\hline Pylodictus olivaris & Bullhead catfish & 9 & 5.89 \\
\hline \multirow[t]{2}{*}{ Osteichthyes } & Unidentified fish & 90 & 29.16 \\
\hline & Total Fishes & 129 & 48.64 \\
\hline Vertebrata & Unidentified bone & 96 & 31.06 \\
\hline \multicolumn{2}{|r|}{ Overall Totals } & 22,092 & $28,970.82$ \\
\hline
\end{tabular}

Three measures of relative abundance were used to estimate the importance of all species to the meat diet as represented by this collection: Number of Identified Specimens (NISP), Minimum Number of Individuals (MNI), and bone weight. NISP is the count of specimens that have been identified to at least the genus taxonomic level. Its use as a measure of relative abundance is problematic (Grayson 1984:20-24; Reitz and Wing 1999:191-192). NISP cannot differentiate between 11 fragments from 11 different cows and 11 fragments of a single cow. Reliance on NISP alone will distort the estimate of relative importance in favor of small animals and animals with parts that are more readily identifiable in fiagmentary form (Grayson 1984:20-24).
Minimum Number of Individuals (MNI) is a derived measure commonly used to get around some of the problems of NISP. MNI is the minimum number of animals of each species that must have been present to account for the elements identified for that species. This is determined by dividing paired elements (or portions of elements such as proximal or distal ends) into right and left sides, and then finding the most abundant such element. Estimated age of the animals (at least immature vs. mature) is often considered in the analysis. MNI can, if properly calculated, be a useful counter-point to NISP. However, MNI also has problems as a measure of relative abundance. One problem with $\mathrm{MNI}$ is the assumption that the presence of an element implies the 
presence of the entire animal. Humans rarely kill, butcher, and eat an animal all in the same location (Lyman 1994:300). Choices are made at each stage of butchery, processing, cooking, and disposal, so that the complete carcass is unlikely to be found in any one location unless it was not eaten (e.g., a rat or snake disposed of in a trash midden).

More importantly, Grayson (1984:29-49) has pointed out that MNI is extremely sensitive to the way in which the analyst aggregates the data. MNI counts can be made to vary a great deal by changing how the analyst groups the data - for instance, by unit/level, by complete unit, by natural level, by the entire site, etc. (see Grayson 1984:34-49). The more inclusive the grouping, the more the data are reduced.

In the particular case of this project, the analyst had a choice of aggregating the collection by unit, by grouping of units, or grouping the entire collection. The analyst chose to group units that were adjacent to each other, and consider nonadjacent units separately. Thus, TUs $5,17,22$, and 26 were grouped, as were TUs 6,15 , and 19 ; TUs 10 and 20 ; and TUs 12,16 , and 18 . Units in the gate area (TUs $28-31,36$ $42,44-45$, and 47-48), the kiln (TUs 32-33, 43, 46, and 49), and the pit feature (TUs 34-35) were also grouped (see Figure 4-2). All other units were considered separately for the purpose of estimating MNI. It is possible that at least some faunal remains were scattered over a wide area, and in such cases, under this method, bone from the same animal might be counted twice in the MNI estimate. However, given the area tested in this project, and the spacing of the units, it seemed that considering the entire collection as a whole would have grossly underestimated the MNI.

Bone weight can also, with caution, be used as a measure of relative abundance. Bone weight is, in general, a better indicator of relative dietary importance (as opposed to relative abundance) than NISP or MNI, but this measure must not be used exclusively. In general, larger bones carry more meat, but the relationship is not linear (Reitz and Wing 1999:222-231), varies among different taxa, and there is considerable variation from one part of the animal to another (e.g., lower legs of cattle are dense, heavy bones but carry relatively little meat compared to other bones of the body). Comparing taxa of different classes can be problematic. For instance, because most of the body weight of fish is carried by the water, their bones are a much smaller percentage of total body weight than is seen in land animals. As a result, the bone weight of fish seriously underestimates the relative importance to the diet when compared with mammals. Using bone weight as an assessment of dietary importance also suffers from the necessary assumption that all taphonomic factors that affect bone weight (such as leaching, mineralization, or encrustation) have affected all bone in the collection uniformly. Bone weight tends to emphasize the importance of larger, heavier animals, and because of this, tends to counter-balance the tendency of NISP to emphasize smaller animals.

Each analytic method discussed above is subject to a number of biases (Reitz and Wing 1999:200). Used together, however, NISP, MNI, and bone weight can provide a better picture of the relative importance of each species to the diet than each method can provide when used alone.

\section{Results}

Table 6-14 shows the bone identified to at least the genus taxonomic level, with bone weight and MNI. The bone was, generally, in very fragmented condition, so that only $3.3 \%$ $(n=726)$ could be identified to the genus taxonomic level, and $92.6 \%(n=20,453)$ of the bone could be identified only as mammalian. A total of 33 genera was identified. Pack rat (Neotoma sp.) is the most common identified bone, constituting $22.2 \%$ of the total NISP. It is unlikely that these animals were part of the diet. They were more likely to have been drawn to the trash in the middens, and may have nested there, or they may have been disposed of after they had been killed elsewhere in the mission.

Of the genera of economic importance, cattle (Bos taurus) are the most common, with $14.6 \%$ of the total NISP, and MNI of 13 (Table 6-14). Small domestic food animals were fairly rare. Together, goat, sheep, and pig were only $8.8 \%$ of the total NISP, but MNI estimates of 4,7 , and 3 respectively, suggest that the percentage of NISP somewhat underestimates their relative abundance. White-tailed deer (Odocoileus virginianus) were more common, with $10.5 \%$ of the NISP, and an MNI of 13. In fact, all wild mammals commonly hunted for food (including deer, rabbit, raccoon, opossum, squirrel, and javelina) taken together were $25.2 \%$ of the total NISP, and $26 \%$ of the total MNI. Turtle bones were $6.7 \%$ of the NISP. Birds and fish were small components of the NISP, constituting only $4.5 \%$ and $5.4 \%$, respectively (Table 6-14).

As mentioned in the Methods section, however, NISP and MNI can both give a false impression of the relative importance of an animal to the diet. The percent of total NISP bone weight for each of the categories mentioned above is listed in Table 6-15. This table shows that the diet 
Table 6-14. Identified Genera, with Count, Bone Weight, and MNI

\begin{tabular}{|c|c|c|c|c|c|c|}
\hline Genera & Count & $\%$ & MNI & $\%$ & Weight (g) & $\%$ \\
\hline Bos taurus & 106 & $14.6 \%$ & 13 & $8.4 \%$ & $3,442.96$ & $68.2 \%$ \\
\hline Canis sp. & 12 & $1.7 \%$ & 4 & $2.6 \%$ & 25.70 & $0.5 \%$ \\
\hline Canis latrans & 2 & $0.3 \%$ & 2 & $1.3 \%$ & 3.02 & $0.1 \%$ \\
\hline Capra hircus & 8 & $1.1 \%$ & 4 & $2.6 \%$ & 33.56 & $0.7 \%$ \\
\hline Conepatus mesoleucus & 3 & $0.4 \%$ & 2 & $1.3 \%$ & 3.20 & $0.1 \%$ \\
\hline Dasypous novemcintus & 2 & $0.3 \%$ & 1 & $0.6 \%$ & 0.41 & $0.0 \%$ \\
\hline Didelphis virginiana & 51 & $7.0 \%$ & 4 & $2.6 \%$ & 38.54 & $0.8 \%$ \\
\hline Equus sp. & 36 & $5.0 \%$ & 3 & $1.9 \%$ & 370.13 & $7.3 \%$ \\
\hline Felis domesticus & 6 & $0.8 \%$ & 1 & $0.6 \%$ & 11.31 & $0.2 \%$ \\
\hline Lepus californicus & 6 & $0.8 \%$ & 4 & $2.6 \%$ & 3.95 & $0.1 \%$ \\
\hline cf. Lynx rufus & 2 & $0.3 \%$ & 1 & $0.6 \%$ & 4.54 & $0.1 \%$ \\
\hline Mephitis mephitis & 1 & $0.1 \%$ & 1 & $0.6 \%$ & 0.30 & $0.0 \%$ \\
\hline Neotoma sp. & 161 & $22.2 \%$ & 26 & $16.9 \%$ & 46.32 & $0.9 \%$ \\
\hline Odocoileus virginianus & 76 & $10.5 \%$ & 13 & $8.4 \%$ & 535.98 & $10.6 \%$ \\
\hline Ovis aries & 26 & $3.6 \%$ & 7 & $4.5 \%$ & 152.64 & $3.0 \%$ \\
\hline Pecari tajacu & 24 & $3.3 \%$ & 7 & $4.5 \%$ & 114.99 & $2.3 \%$ \\
\hline Procyon lotor & 3 & $0.4 \%$ & 3 & $1.9 \%$ & 3.39 & $0.1 \%$ \\
\hline Sciurus sp. & 4 & $0.6 \%$ & 2 & $1.3 \%$ & 1.83 & $0.0 \%$ \\
\hline Sigmodon hispidus & 18 & $2.5 \%$ & 5 & $3.2 \%$ & 3.51 & $0.1 \%$ \\
\hline Sus scrofa & 30 & $4.1 \%$ & 3 & $1.9 \%$ & 70.47 & $1.4 \%$ \\
\hline Sylvilagus sp. & 25 & $3.4 \%$ & 7 & $4.5 \%$ & 9.41 & $0.2 \%$ \\
\hline Total Mammals & 602 & $82.9 \%$ & 113 & $73.4 \%$ & $4,876.16$ & $96.6 \%$ \\
\hline Anas sp. & 6 & $0.8 \%$ & 2 & $1.3 \%$ & 2.18 & $0.0 \%$ \\
\hline Gallus domesticus & 18 & $2.5 \%$ & 7 & $4.5 \%$ & 12.32 & $0.2 \%$ \\
\hline Meleagris gallopavo & 9 & $1.2 \%$ & 3 & $1.9 \%$ & 9.82 & $0.2 \%$ \\
\hline Total Birds & 33 & $4.5 \%$ & 12 & $7.8 \%$ & 24.32 & $0.5 \%$ \\
\hline Chelydra serpentina & 1 & $0.1 \%$ & 1 & $0.6 \%$ & 0.73 & $0.0 \%$ \\
\hline Crotalus sp. & 2 & $0.3 \%$ & 2 & $1.3 \%$ & 0.51 & $0.0 \%$ \\
\hline Pseudomys sp. & 3 & $0.4 \%$ & 3 & $1.9 \%$ & 3.88 & $0.1 \%$ \\
\hline Terrepene sp. & 10 & $1.4 \%$ & 4 & $2.6 \%$ & 8.82 & $0.2 \%$ \\
\hline Trionyx sp. & 35 & $4.8 \%$ & 5 & $3.2 \%$ & 112.43 & $2.2 \%$ \\
\hline Total Reptiles & 51 & $7.0 \%$ & 15 & $9.7 \%$ & 126.37 & $2.5 \%$ \\
\hline Rana sp. & 1 & $0.1 \%$ & 1 & $0.6 \%$ & 0.19 & $0.0 \%$ \\
\hline Total Amphibians & 1 & $0.1 \%$ & 1 & $0.6 \%$ & 0.19 & $0.0 \%$ \\
\hline Aplodinotus grunniens & 2 & $0.3 \%$ & 1 & $0.6 \%$ & 1.21 & $0.0 \%$ \\
\hline Ictalurus sp. & 25 & $3.4 \%$ & 7 & $4.5 \%$ & 11.73 & $0.2 \%$ \\
\hline Lepisosteus sp. & 3 & $0.4 \%$ & 3 & $1.9 \%$ & 0.65 & $0.0 \%$ \\
\hline Pylodictus olivaris & 9 & $1.2 \%$ & 2 & $1.3 \%$ & 5.89 & $0.1 \%$ \\
\hline Total Fish & 39 & $5.4 \%$ & 13 & $8.4 \%$ & 19.48 & $0.4 \%$ \\
\hline TOTAL & 726 & $100.0 \%$ & 154 & $100.0 \%$ & $5,046.52$ & $100.0 \%$ \\
\hline
\end{tabular}


Table 6-15. Percentage of NISP Bone Weight for Selected Categories

\begin{tabular}{|l|r|}
\hline \multicolumn{1}{|c|}{ Category } & $\begin{array}{c}\text { \% of } \\
\text { NISP Wgt. }\end{array}$ \\
\hline Cattle & $68.2 \%$ \\
\hline Other domestic artiodactyls & $5.1 \%$ \\
\hline Wild Mammals & $14.0 \%$ \\
\hline Birds & $0.5 \%$ \\
\hline Turtles & $2.5 \%$ \\
\hline Fish & $0.4 \%$ \\
\hline
\end{tabular}

is dominated by cattle, but that wild mammals are also an important part of the diet.

\section{Butchering}

Butchering marks were recorded only on bone that was identified to at least the order taxonomic level, with one exception. All saw marks on bones were recorded. This was considered important because sawing bone is a significant temporal indicator. Although we to not know exactly when bone sawing became the normal method of butchery in San Antonio, we do know that sawed bone is never seen in purely Colonial contexts in the San Antonio missions (for instance, no sawed bone was recovered from a well-sealed Colonialperiod bone bed outside the west wall of Mission San Antonio de Valero [see Meissner 1999a]). It is likely that sawing was introduced by professional butchers at some point in the nineteenth century and was not used in the "home butchering" of the mission inhabitants until after secularization. Butcher marks were observed on 104 bones. Table 6-16 lists the butcher mark types and the number of bones displaying these marks by taxon.

Only nine bones in the collection $(0.04 \%$ of the total) showed evidence of being sawed. Of these, the type of saw could not be identified on one bone; four bones had been sawed with a machine saw, indicating butchering in the twentieth century. Four of the sawed bones were cut with handsaws, a nineteenth-century butchering practice. All sawed bone came from levels that showed extensive mixing of Colonial with post-Colonial artifacts.

Most of the bones with butcher marks had been chopped (64 of 104, 61.5\%). There were impact scars on a total of 21 bones $(20.2 \%)$, all but two of which were long bones. Two bovid ribs also had impact scars.
One soft shell turtle shell (Trionyx sp.), in 19 pieces, is not included in the list in Table 6-16. When the shell was reconstructed, the method used to open the shell became evident. A large percent of the carapace is present, and it has been broken all around the outer edge of the costal bones by a series of impacts (Figure 6-22). There is some smoke staining along this broken margin, but none elsewhere on the carapace. This suggests that turtle shell was broken open, then placed over (or in) the fire for a short time. This was probably done to make removal of the meat from the shell easier. The body of the turtle protected the inner surface of the carapace from heat alteration, and the outer carapace was protected by its leathery cover from which this family of turtles gets its common name.

\section{Pathologies}

Pathologies were noted on only two bones in this collection. They are carpal bones of an unidentified artiodactyl, which appeared to articulate, both showing evidence of some sort of inflammatory process.

\section{Evidence of Heat Alteration}

The duration and intensity of heating necessary to calcine bone is considerable. It is unlikely to occur during routine cooking, even over an open fire (Lyman 1994:388-389). Five percent $(n=1,102)$ of the bone from this collection showed evidence of heat alteration, but there was a marked difference both in the number of burned bones, and in the degree of heat alteration, depending on where in the project area the bone was collected. Table 6-17 shows the count of bone that is smoke stained, charred, partially calcined, and calcined, by area.

It is interesting that nearly half the bone recovered from the kiln shows evidence of heat alteration, of which $74.4 \%$ is completely calcined (Table 6-17). This included some quite large bones. It strongly suggests that bone was being used as part of the fuel in the firebox of the kiln. This pattern is unusual. A review of the literature reveals only one case which had such large numbers of heavily burned bone in a Colonial-period site (McKee and Langenwalter 1985), and this case was also in association with a kiln. In addition, the author has examined bone from Ft. St. Louis, a French and Spanish site in Victoria County where there was a large number of burned bones not associated with a kiln. In that case, bone was apparently used as fuel due to scarcity of firewood (Meissner 2003). 
Table 6-16. Butcher Marks Recorded by Taxon and Type

\begin{tabular}{|c|c|c|c|}
\hline Taxon & Bone & Type & Count \\
\hline \multirow{12}{*}{ Bos taurus } & Cranium & Cut & 1 \\
\hline & Femur & Impact scar & 1 \\
\hline & Lumbar vertebra & Chop & 2 \\
\hline & Metacarpal & Cut & 1 \\
\hline & \multirow[t]{2}{*}{ Radius } & Chop & 1 \\
\hline & & Impact scar & 1 \\
\hline & Rib & Chop & 3 \\
\hline & \multirow[t]{2}{*}{ Scapula } & Chop & 1 \\
\hline & & Impact scar & 1 \\
\hline & \multirow[t]{3}{*}{ Ulna } & Cut & 1 \\
\hline & & Chop & 1 \\
\hline & & Impact scar & 2 \\
\hline \multirow{2}{*}{ Capra hircus } & Calcaneus & Impact scar & 1 \\
\hline & Radius & Chop & 1 \\
\hline \multirow{2}{*}{ Capra/Ovis } & \multirow[t]{2}{*}{ Tibia } & Cut & 1 \\
\hline & & Impact scar & 1 \\
\hline \multirow{8}{*}{$\begin{array}{l}\text { Odocoileus } \\
\text { virginianus }\end{array}$} & Humerus & Impact scar & 1 \\
\hline & Innominate & Chop & 1 \\
\hline & Metatarsal & Chop & 3 \\
\hline & \multirow[t]{3}{*}{ Radius } & Cut & 1 \\
\hline & & Chop & 1 \\
\hline & & Impact scar & 1 \\
\hline & Scapula & Chop & 1 \\
\hline & Tibia & Impact scar & 3 \\
\hline \multirow{2}{*}{ Ovis aries } & \begin{tabular}{|l|} 
Astalagus \\
\end{tabular} & Chop & 1 \\
\hline & Metatarsal & Cut & 1 \\
\hline \multirow{4}{*}{ Pecari tajacu } & Astalagus & Chop & 1 \\
\hline & Cranium & Chop & 1 \\
\hline & \multirow[t]{2}{*}{ Humerus } & Chop & 1 \\
\hline & & Impact scar & 2 \\
\hline \multirow{2}{*}{ Sus scrofa } & Humerus & Chop & 1 \\
\hline & Scapula & Chop & 1 \\
\hline
\end{tabular}

In other parts of the project area, burned bone is much less common, and shows a very different distribution of degree of heat alteration. In the units at the gate and along the west wall, $70 \%$ of burned bone is either smoke stained or charred (Table 6-17). This pattern is indicative of cooking, with some disposal of bone in the fire. Only $1.0 \%$ of the bone in the pit was burned, $87.1 \%$ of which was smoke stained or charred. It does not appear that bone was used as fuel except in the kiln.
Table 6-16. continued...

\begin{tabular}{|c|c|c|c|}
\hline Taxon & Bone & Type & Count \\
\hline \multirow{18}{*}{ Artiodactyl } & Calcaneus & Chop & 1 \\
\hline & Femur & Chop & 4 \\
\hline & \multirow[t]{2}{*}{ Humerus } & Chop & 1 \\
\hline & & Impact scar & 2 \\
\hline & Innominate & Chop & 1 \\
\hline & Lateral phalange & Chop & 1 \\
\hline & Lumbar vertebra & Chop & 5 \\
\hline & \multirow[t]{2}{*}{ Metapodial } & Cut & 1 \\
\hline & & Chop & 2 \\
\hline & \multirow[t]{2}{*}{ Radius } & Chop & 1 \\
\hline & & Impact scar & 1 \\
\hline & \multirow[t]{2}{*}{ Rib } & Cut & 2 \\
\hline & & Chop & 4 \\
\hline & Scapula & Chop & 1 \\
\hline & Thoracic vertebra & Chop & 3 \\
\hline & \multirow[t]{2}{*}{ Tibia } & Chop & 2 \\
\hline & & Impact scar & 1 \\
\hline & UIna & Chop & 1 \\
\hline \multirow{11}{*}{ Bovine } & 1st Phalange & Chop & 1 \\
\hline & Astalagus & Chop & 1 \\
\hline & \multirow[t]{2}{*}{ Axis } & Cut & 1 \\
\hline & & Chop & 1 \\
\hline & \multirow[t]{2}{*}{ Lumbar vertebra } & Cut & 1 \\
\hline & & Chop & 2 \\
\hline & \multirow[t]{3}{*}{ Rib } & Cut & 1 \\
\hline & & Chop & 7 \\
\hline & & Impact scar & 2 \\
\hline & Sacrum & Chop & 1 \\
\hline & Thoracic vertebra & Chop & 3 \\
\hline \multirow{5}{*}{ Large Mammal } & \multirow[t]{5}{*}{ Long bones } & Chop & 1 \\
\hline & & Impact scar & 1 \\
\hline & & Hand saw cut & 4 \\
\hline & & Machine saw cut & 4 \\
\hline & & Indeter. saw cut & 1 \\
\hline & & Overall total ${ }^{*}$ & 107 \\
\hline
\end{tabular}

*Some bones had more than one type of butcher mark.

\section{Discussion}

This collection is similar to several other faunal collections from San Antonio missions. Table 6-18 shows the percent of NISP bone weight for six categories of fauna from six recent projects at four San Antonio missions. The bone from the current project closely resembles bone from three projects along the south wall of Mission San José (Meissner 1998b, 1999a, 1999b). The assemblage from the Mission 


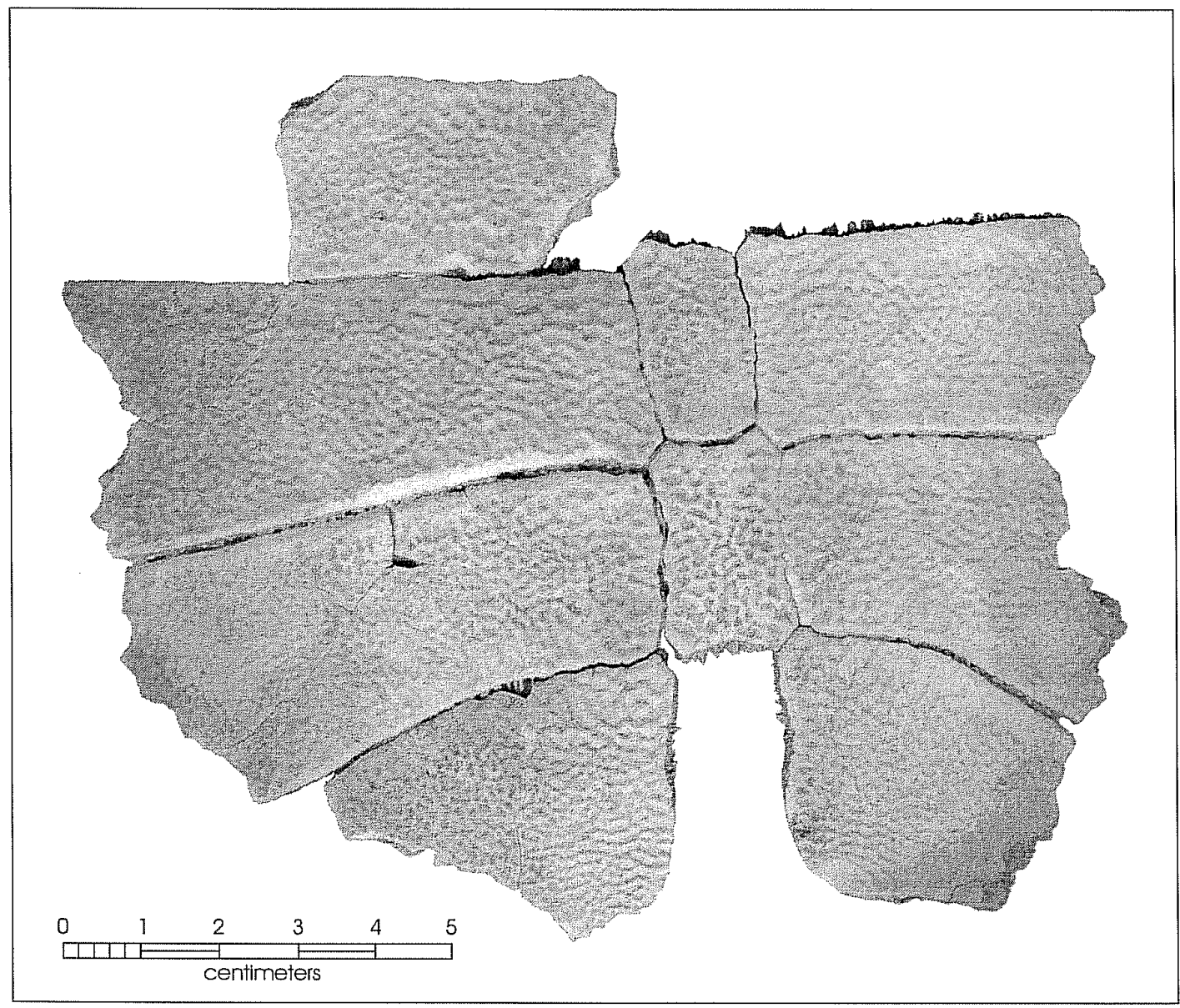

Figure 6-22. Soft-shelled turtle carapace, showing impact scars and burning around edge.

Table 6-17. Bone Displaying Heat Alteration by Area

\begin{tabular}{|l|r|r|r|r|}
\hline & \multicolumn{1}{|c|}{ Kiln } & $\begin{array}{c}\text { Gate Area \& } \\
\text { West Wall }\end{array}$ & \multicolumn{1}{c|}{ Pit } & Total \\
\hline Smoke stained & 19 & 173 & 8 & $\mathbf{2 0 0}$ \\
\hline Charred & 102 & 172 & 19 & $\mathbf{2 9 3}$ \\
\hline Partially calcined & 27 & 111 & 2 & $\mathbf{1 4 0}$ \\
\hline Calcined Total & 430 & 37 & 2 & 469 \\
\hline $\mathbf{5 7 8}$ & $\mathbf{4 9 3}$ & $\mathbf{3 1}$ & $\mathbf{1 1 0 2}$ \\
\hline $\begin{array}{r}\text { Percentage of Total } \\
\text { Area Bone Count }\end{array}$ & $46.4 \%$ & & & \\
\hline \multicolumn{4}{r}{} \\
\hline
\end{tabular}


Table 6-18. Percent of NISP Bone Weight for Six Categories from Six Projects at Four San Antonio Missions

\begin{tabular}{|c|c|c|c|c|c|c|c|}
\hline \multirow[b]{3}{*}{ Categories } & \multicolumn{7}{|c|}{$\%$ of NISP Weight } \\
\hline & \multicolumn{2}{|c|}{ Espada } & \multicolumn{3}{|c|}{ San José } & \multirow{2}{*}{$\begin{array}{c}\text { Concepción } \\
\text { Meissner } \\
2000 \mathrm{~b}\end{array}$} & \multirow{2}{*}{$\begin{array}{c}\text { San Juan } \\
\text { Meissner } \\
2000 \mathrm{c}\end{array}$} \\
\hline & $\begin{array}{l}\text { Current } \\
\text { Project }\end{array}$ & $\begin{array}{c}\text { Meissner } \\
2000 \mathrm{a}\end{array}$ & $\begin{array}{c}\text { Meissner } \\
1999 \mathrm{~b}\end{array}$ & $\begin{array}{c}\text { Meissner } \\
1999 \mathrm{c}\end{array}$ & $\begin{array}{c}\text { Meissner } \\
\text { 1998b }\end{array}$ & & \\
\hline Cattle & $66.2 \%$ & $36.0 \%$ & $78.0 \%$ & $64.8 \%$ & $76.0 \%$ & $84.3 \%$ & $80.2 \%$ \\
\hline $\begin{array}{c}\text { Sheep, Goats, } \\
\text { \& Pigs }\end{array}$ & $5.1 \%$ & $33.2 \%$ & $6.3 \%$ & $6.5 \%$ & $6.3 \%$ & $0.7 \%$ & $4.4 \%$ \\
\hline Wild Mammals & $14.1 \%$ & $5.2 \%$ & $12.2 \%$ & $13.6 \%$ & $0.6 \%$ & $6.8 \%$ & $4.6 \%$ \\
\hline Birds & $0.5 \%$ & $3.2 \%$ & $0.4 \%$ & $1.3 \%$ & $1.1 \%$ & $0.4 \%$ & $1.0 \%$ \\
\hline Turtles & $2.2 \%$ & $0.7 \%$ & $2.4 \%$ & $4.4 \%$ & $1.5 \%$ & $1.3 \%$ & $1.6 \%$ \\
\hline Fish & $0.4 \%$ & $3.1 \%$ & $0.9 \%$ & $1.2 \%$ & $0.8 \%$ & $0.6 \%$ & $0.4 \%$ \\
\hline
\end{tabular}

Concepción project is believed to be a butchering discard midden rather than a general trash midden, which would explain the high percentage of cattle bone. Cattle are also more dominant in the bone from Mission San Juan. Each of the projects listed in Table 6-18, except the Priest Quarters project at Espada (Meissner 2000a), is somewhat different, but in general these five collections are much the same. In all, beef is the dominant item in the diet, although the degree to which wild mammals commonly hunted for food are included in the diet is variable. Smaller domestic food animals are present in small numbers. Birds, turtles, and fish each provide a small percentage of total NISP bone weight.

It is interesting that this collection is very different from the faunal remains recovered from outside the walls of the priests quarters during recent excavations at Espada (Zapata et al. 2000). The bone from the Priest Quarters project was not nearly as fragmented (Table 6-19). Cattle represent only $4.6 \%$ of the total NISP for that collection and only $36 \%$ of the total NISP bone weight, compared to an average among the other five collections listed in Table 6-18 of 74.9\% of NISP bone weight. Domestic food animals such as goats, sheep, and pigs are $24 \%$ of the NISP. Fish and chicken are much more abundant than is true of the bone from the current project (Table 6-19). Though the priest quarters are only about $30 \mathrm{~m}$ from the gate area units (see Figure 3-1), the difference in the two collections is striking. The most likely explanation is that the Priest Quarters excavation recovered material discarded from the priests' kitchen, and that the priests' diet was somewhat different from the diet of the other mission inhabitants (Meissner 2000a).
This collection, like most collections from mission sites in San Antonio, is highly fragmented, with only 3.3\% identified to the genus taxonomic level. The nature of the fragmentation is difficult to assess. One almost complete Bos scapula, for instance, which had been deposited intact, arrived at the lab in 32 pieces. This fragmentation was due to the fragile nature of this large, flat bone and cultural and non-cultural taphonomic factors that made the bone very brittle. The extremely fragmented nature of most of the bone in the gateway area, where only 83 of 3,542 bones could be identified and the average bone weight was only 0.82 grams, is at least partially the result of years of automobile traffic over the area. At least some of the fragmentation of other bones can be attributed to similar processes.

However, there is evidence that other cultural processes are at least partially responsible for the large numbers of highly fragmented bone. Of the 273 bovid bones identified in the collection (bone identified as Bos and that which could only be identified as Bovinae), only 41 are identified fragments of long bones, including metapodials. Of those, all but 15 were found in the pit feature or in the kiln (Table 6-20). If the pit and the kiln area are excluded and we examine the units in the gateway area and along the west wall, we see that only 147 bovid elements were identified, and of these, only 15 were long bone fragments. In addition, 1,562 bones were from bovid-sized animals, and 14,392 mammalian bones were so fragmented that it was not possible to assign them to an estimated size of animal, although perhaps as much as $75 \%$ of these bones were probably also from bovidsized animals. 
Table 6-19. Comparison of Current Project with Bone from Priest Quarters Project (Meissner 2000a)

\begin{tabular}{|c|c|c|c|c|}
\hline & \multicolumn{2}{|c|}{ Current Project } & \multicolumn{2}{|c|}{ Priest Quarters Project } \\
\hline Total Bone & \multicolumn{2}{|c|}{22,092} & \multicolumn{2}{|c|}{6,485} \\
\hline \% Identified to Genus & \multicolumn{2}{|c|}{$3.3 \%$} & \multicolumn{2}{|c|}{$6.0 \%$} \\
\hline Average Bone Wgt. (g) & \multicolumn{2}{|c|}{1.31} & \multicolumn{2}{|c|}{1.93} \\
\hline Genera & Count & $\begin{array}{c}\% \text { of total } \\
\text { NISP }\end{array}$ & Count & $\begin{array}{c}\% \text { of total } \\
\text { NISP }\end{array}$ \\
\hline Bos & 106 & $14.6 \%$ & 18 & $4.6 \%$ \\
\hline Capra & 8 & $1.1 \%$ & 16 & $4.1 \%$ \\
\hline Equus & 36 & $5.0 \%$ & 3 & $0.8 \%$ \\
\hline Odocoileus & 76 & $10.5 \%$ & 21 & $5.4 \%$ \\
\hline Ovis & 26 & $3.6 \%$ & 67 & $17.3 \%$ \\
\hline Sus & 30 & $4.1 \%$ & 10 & $2.6 \%$ \\
\hline Sylvilagus & 25 & $3.4 \%$ & 8 & $2.1 \%$ \\
\hline Gallus & 18 & $2.5 \%$ & 42 & $10.8 \%$ \\
\hline Meleagris & 9 & $1.2 \%$ & 7 & $1.8 \%$ \\
\hline Pseudomys & 3 & $0.4 \%$ & 0 & $0.0 \%$ \\
\hline Trionyx & 35 & $4.8 \%$ & 4 & $1.0 \%$ \\
\hline Ictalurus & 25 & $3.4 \%$ & 88 & $22.7 \%$ \\
\hline Pylodictus & 9 & $1.2 \%$ & 61 & $15.7 \%$ \\
\hline Total Selected Genera & 406 & $55.9 \%$ & 345 & $88.9 \%$ \\
\hline Total NISP & 726 & $100.0 \%$ & 388 & $100.0 \%$ \\
\hline
\end{tabular}

Table 6-20. Location of Identified Bovid Long Bone Fragments

\begin{tabular}{|l|c|}
\hline Location & Identified Bovid Long Bones \\
\hline Pit & 24 \\
\hline Kiln & 2 \\
\hline Other & 15 \\
\hline & 41 \\
\hline
\end{tabular}

One possible explanation for this fragmentation is that the mission inhabitants were processing the beef carcasses for bone grease. Bone grease is a concentrated food, containing protein and vitamins as well as fat, and has the added advantage of being storable (Vehik 1977:172). Extraction of bone grease involves breaking bone, especially the ends of long bones, which have a high fat content, into small pieces and then boiling them for an extended period of time. Bone fat melts out of the bone and floats to the surface where it is periodically skimmed off (Vehik 1977:171). The shattering of the bone ends leaves them much less identifiable. The boiling removes nutrients and makes the bone more friable after burial (Nicholson 1996; Vehik 1977:173). The result is large numbers of unidentifiable bones and few, if any, bovid long bone ends.

This is the pattern seen in the faunal collection from the gateway area and the west wall, where only $10 \%$ (15 of 147) of the identified bovid bones were long bone fragments. In contrast, the pit feature contains 105 identified bovid bones, of which $23(22 \%)$ are long bone fragments. The large numbers of unidentifiable bone and small numbers of bovid long bones strongly suggests that, during at least some time in the mission period, bovid bone was being processed to extract bone grease, and the remains of this operation were being dumped near the gate and along the west wall of the mission.

This is a pattern that, while not universal at mission sites, is not uncommon. In particular, a series of recent excavations along the south wall of Mission San José y San Miguel, a few miles north of Mission Espada, also had large numbers of unidentifiable mammalian bone and very few, if any, identifiable bovid long bones (Meissner 1998b:38-39, 1999b:38-40, 1999c:45-46). 


\section{Summary and Conclusions}

The 22,092 bones from this project are highly fragmented, with only $3.3 \%$ identifiable to the genus taxonomic level. The meat diet represented by these identified specimens is dominated by beef, but there are a significant number of wild mammals, especially deer, also present (Table 6-14). Other domestic food animals are much less common. Only very small numbers of fish and birds were identified. In many ways, this collection can be considered typical of mission bone collections, although there is a larger percent of wild mammals commonly hunted for food than is usually seen in such collections (Table 6-18).

Evidence from heat-altered bone strongly suggests that bone was used as fuel in the pottery kiln. Elsewhere, bone was not routinely thrown into the fire, either as fuel or as a method of disposal.

The small numbers of bovid long bone fragments, and the large number of unidentifiable fragments in the units in the gateway and along the west wall, suggest that bovid bone was being processed to extract bone grease. The collection in the gateway area seems to represent part of a general trash dump in which the remains of bone grease extraction, among other bones, were dumped. The bone in the pit feature, however, has a much higher percentage of bovid long bones, suggesting that during the time this feature was being used as a dump, bovid bones were not being as intensively processed.

In conclusion, this collection is similar to most other faunal collections from nearby missions. It is, however, very different from the faunal collection recovered from excavations at the priests' quarters at Mission Espada (Table 6-19). This collection helps to point out that, within the general pattern of a beef dominated diet at the San Antonio missions, there was some variation both within each mission and from one mission to another. 



\section{Chapter 7: Discussion}

This project has provided an opportunity to examine artifacts and features from an unusually large area in the vicinity of one of the five missions of San Antonio. The 32,740 artifacts and 12 features identified have the potential to greatly increase our understanding of the mission inhabitants and their activities.

\section{The Pottery Kiln}

The kiln, in particular, adds greatly to our knowledge of post-secularization life at Mission Espada. Since no mention of wheel-thrown vessels and no mention of a pottery kiln is made in mission inventories, the kiln must represent the adoption of European pottery-making techniques at some point after the last of the mission inventories was completed.

When Native Americans settled in Mission Espada, they continued to make pottery indistinguishable from the kind they had been making for some 800 years. The simple bowls and jars of Goliad ware made at the missions in Colonial times were fired in open fires or shallow pits, which achieved relatively low temperatures. In this method, pottery to be fired is arranged on a bed of fuel on the ground and surrounded with more fuel. This is ignited and after the fuel has burned itself out, the firing is finished (Rice 1987:153). Evidence for the use of this method is the wide range of colors indicating variations in the degree of heat the vessels received and black cores evident on the sherds indicating that the vessels were not thoroughly fired at a temperature that insured total oxidation.

Firing in a kiln protects the pottery from drafts and permits higher temperatures, not to mention more efficient use of fuel. There are two basic types of pottery kilns, updraft kilns fired from below so that the heat rises upward through the vessels and out the top, and downdraft kilns fired from the side with the heat being drawn through the vessels and out a chimney on the opposite side (Noel Hume 1969:168).

Brick is a popular material used for building kilns because of its ability to withstand the constant heating and cooling of kiln operation (Rice 1987:158). Given the customary shape of bricks, it is easier to build a square or rectangular kiln of brick than a round one, which would explain the shape of the Espada kiln. Although it is difficult to tell from the remains left in the ground, it appears that this was a double-chambered updraft kiln (Figure 7-1). The lower chamber was the firebox and above this would have sat the firing chamber that was evidently allowed to collapse or was intentionally dismantled after the kiln was no longer in use. The fact that the firebox is surrounded by dark brown clay/loam confirms that the kiln structure did not extend any farther to the north, west, or south and that it probably did not have a chimney. The surrounding clay would also have helped to maintain the heat in the kiln. It seems very possible that the excavation of the large pipe trench on the east side of the kiln removed all traces of a chamber or passage that would have extended in that direction in order to allow stoking of the fire in the kiln. The opening of this passage would have been located in the side of a natural drainage channel that probably once ran from the road toward the river. Unfortunately, the pipe trench that enlarged and deepened this drainage was excavated before the archeological crew arrived on the site, and they were not able to observe its original shape and size.

The large number of bricks represented by the 218 fragments recovered from the kiln fill, plus an even larger number of bricks and fragments scattered around the site, confirms that there must have been a good-sized firing chamber with perhaps a domed roof of bricks or large pottery sherds containing flue holes to allow the escape of the heat and smoke. The roof would have to be removed to empty the kiln, then rebuilt each time it was reused (Noel Hume 1969:168).

There would have been a grate of metal or fired clay suspended over the firebox to hold vessels above the fire and allow the heat to rise through them. A central, circularshaped area outlined with burned daub recorded in the sixth level of the kiln excavation may well have been the remains of a support for this grate. Fragments of green glazed "slag" recovered from this level and seen on some of the kiln pottery fragments is actually the product of the melting of overhead bricks that sometimes drip onto objects within the kiln when overheating occurs (Greer 1999:227). There were no indications in the fill of kiln furniture such as saggars or other fired clay objects to support the vessels to be fired so as to obtain the benefit of the rising heat in the kiln (South 1999:295), suggesting that they must have been stacked one upon another. Since the vessels from this 


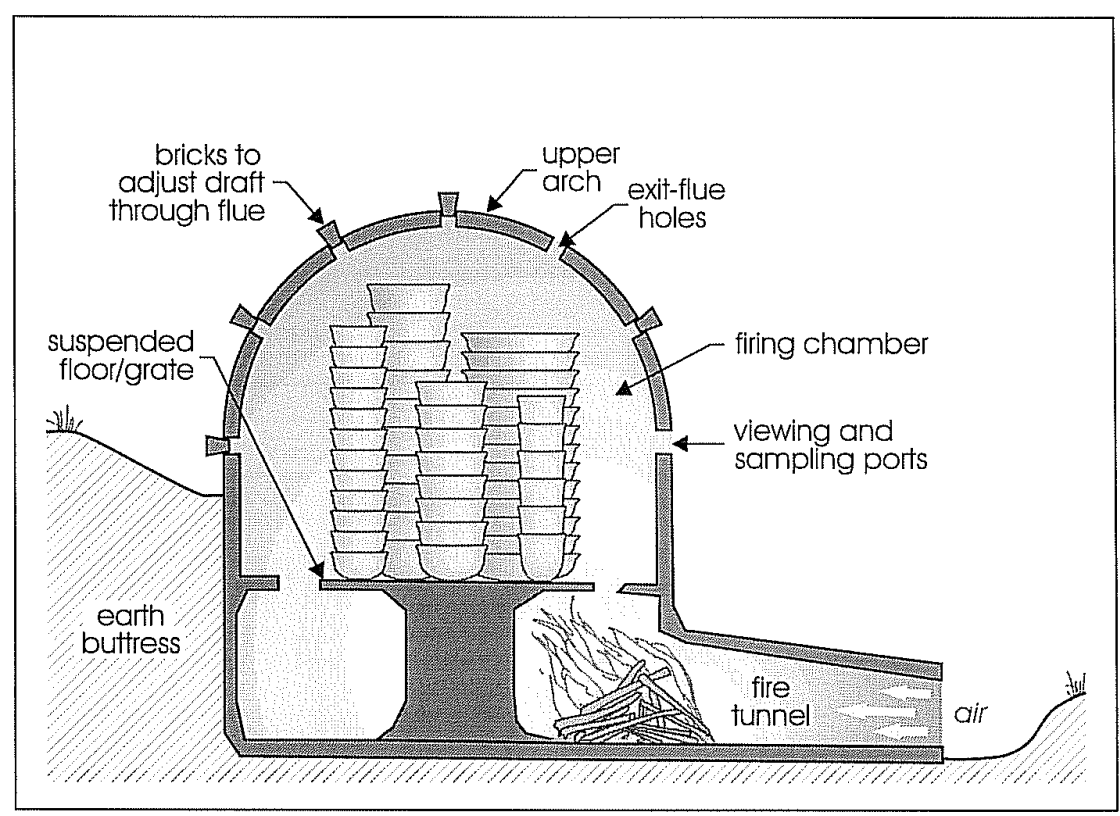

Figure 7-1. Stylized drawing of an updraft kiln, believed to the similar to the kiln in Drainage System $A$.

kiln all appear to be unglazed, they would probably not have had a tendency to stick together, a common problem when firing glazed pots.

When a pottery kiln is in use, all vessels that are broken or misshapen during firing are discarded in what is generally known as a waster pile to one side of the kiln entrance, usually downhill as a matter of convenience. The artifacts found in the kiln present a picture of someone shoveling the contents of the waster pile into the empty kiln in order to fill it in, with the sherd-filled deposits collecting against the north and west walls, slanting downward toward the southeast. The apparent break in the deposits at Level 5, with a deposit of soil containing mission-period artifacts, suggests a different origin for the fill in the top four levels. Perhaps wagonloads were brought from the vicinity of the mission gate midden.

The fact that this pottery was made with a potter's wheel and fired in what appears to be a well-made kiln suggests that the potter was knowledgeable about his or her craft and operated in a post-mission setting, since to our knowledge there were no potter's wheels at the mission during Colonial times. The only kiln mentioned in the inventories is a brick kiln, meaning one specifically for firing bricks. In any case, the ceramics made in this kiln do not appear to have been a major economic success, since they have not been a noticeable component of the archeological record in San Antonio, or even at Espada itself.

The obvious use of mission-made bricks (ladrillos) suggests that there must have been a supply of these somewhere in the vicinity. The 1772 inventory of Espada specified that there were 10,000 ladrillos (rectangular roof tiles) as well as 300 baldosas (square floor tiles) on hand at that time, the products of the mission brick kiln (Ivey et al. 1990:201). There could have been many left over when our potter decided to build his kiln.

\section{The Pit Feature}

As has been mentioned, the pit feature located near the kiln may be a borrow pit from which the potter dug clay for pots (see Figure 5-1). The presence of what appears to be episodes of natural infilling (see Figure 5-2) suggests the pit was open for some time before it was deliberately filled. The lower fill is nearly sterile, while the upper part of the fill is very similar to the upper layers of fill in the kiln. Both contain a large number of Colonial artifacts and smaller numbers of post-Colonial artifacts. It is possible that the upper part of 
both holes were filled at the same time and from the same source. As mentioned above, that source may have been part of the midden near the gateway, as it closely resembles this area in terms of the type of artifacts present.

\section{The Limestone Foundation}

The limestone foundation uncovered in the Northwest Gateway units (see Chapter 5) presents an interesting dilemma. Taken at face value, it appears that there was no gate at the location where reconstruction of the mission has placed it. Yet, the excavation of TU 1 shows clearly the remains of a Colonial foundation for the northern part of the reconstructed gate room (see Figures 4-2 and 5-17).

It seems most likely that the foundation located during this project is the remains of the original west wall of the mission, built around 1756 (Habig 1968:211). If this is the case, then the wall may have been opened at this location after 1785, and "gate rooms" north and south of the opening added. Only one of these rooms, the northern, has been reconstructed (see Figure 2-1). It is possible that the limestone paving found outside the foundation in the Northwest Gateway units (see Figure 5-13) is all that remains of the flooring of the southern gate room. The finding of similar flagstone paving in the rooms now used as a Visitors' Center on the southeast corner of the mission (Escobedo 1984) strongly hints at this possibility (see Figure 3-1). Only a full excavation of the area west and south of the Northwest Gateway units could confirm the presence of a southern "gate room" to correspond to the partially reconstructed room on the northern side of the gate. Testing inside the northern gate room might show the remains of flagstone paving in that room as well.

\section{Research Issues}

The research issues presented in Chapter 1 are based on issues described in the original scope of work for this project and are primarily concerned with the midden deposit near the gate. They will be considered below.

What is the age of the midden deposit along the west wall of the mission?

In order to answer this question, the midden area must be defined. By examining the artifact density (that is the number of artifacts per cubic meter excavated in each unit) of the units along the Hike-and-Bike Trail, a distinct distribution is noted. As shown in Figure 7-2, the units located in the southern portion of the Hike-and-Bike Train (TU 2 through TUs 5, 17, 22, and 26) have a high density of artifacts, above 2,000 per $\mathrm{m}^{3}$. The only other units with an artifact density above 2,000 are TU 23 and TUs 12,16 , and 18 near the northern end of the tested area (TUs 10 and 20 have an artifact density that is nearly 2,000 per $\mathrm{m}^{3}$, as well).

The units nearer the gate, with a high artifact density are, therefore, defined as the "gate midden." These units are TUs $1,2,3,4,5,17,21,22,24,25$, and 26 (see Figure 4-2). Among these units, $88 \%$ of all datable artifacts are Colonial in origin (Table 7-1). Nineteenth-century artifacts are present, but are only a small percentage of the total. Of the 50 twentieth-century artifacts recovered from these units, $72 \%(n=36)$ come units TU 26 and TU 17 . These twentiethcentury artifacts are confined to the upper two levels in TU 26 , and TU 17 is known to be disturbed (see unit description in Chapter 5). The units in the gateway itself are known to be heavily disturbed, yet they too show a strong Colonial component (Table 7-1).

The midden in the gateway and along the southern part of the Hike-and-Bike Trail is, therefore, largely Colonial in origin. While there is evidence of a small component of nineteenth-century additions, and some twentieth-century intrusions, the midden can be considered primarily Colonial in origin.

\section{Is the midden the result of a general trash discard, or is it associated with a specific activity (such as butchering, etc.)?}

The midden appears to be the result of general trash disposal. There are large numbers of ceramics $(n=2,134)$ and large numbers of animal bone $(n=10,113)$, but the latter is in too poor a condition to be able to reliably determine if it is a general or butchering refuse pile. However, only nine bovid phalanges were recovered in the midden area, strongly suggesting that this was not a butchering refuse pile, as these dense bones should be in much more abundance if that were the case.

\section{Was the trash discarded in a pit or was it} discarded as a sheet deposit?

Such trash pits have been found in Colonial contexts. A good example is the refuse pits found at Mission Nuestra Señora del Refugio, in Refugio County (Tennis 2002). However, there was no evidence of such pits found during this project 


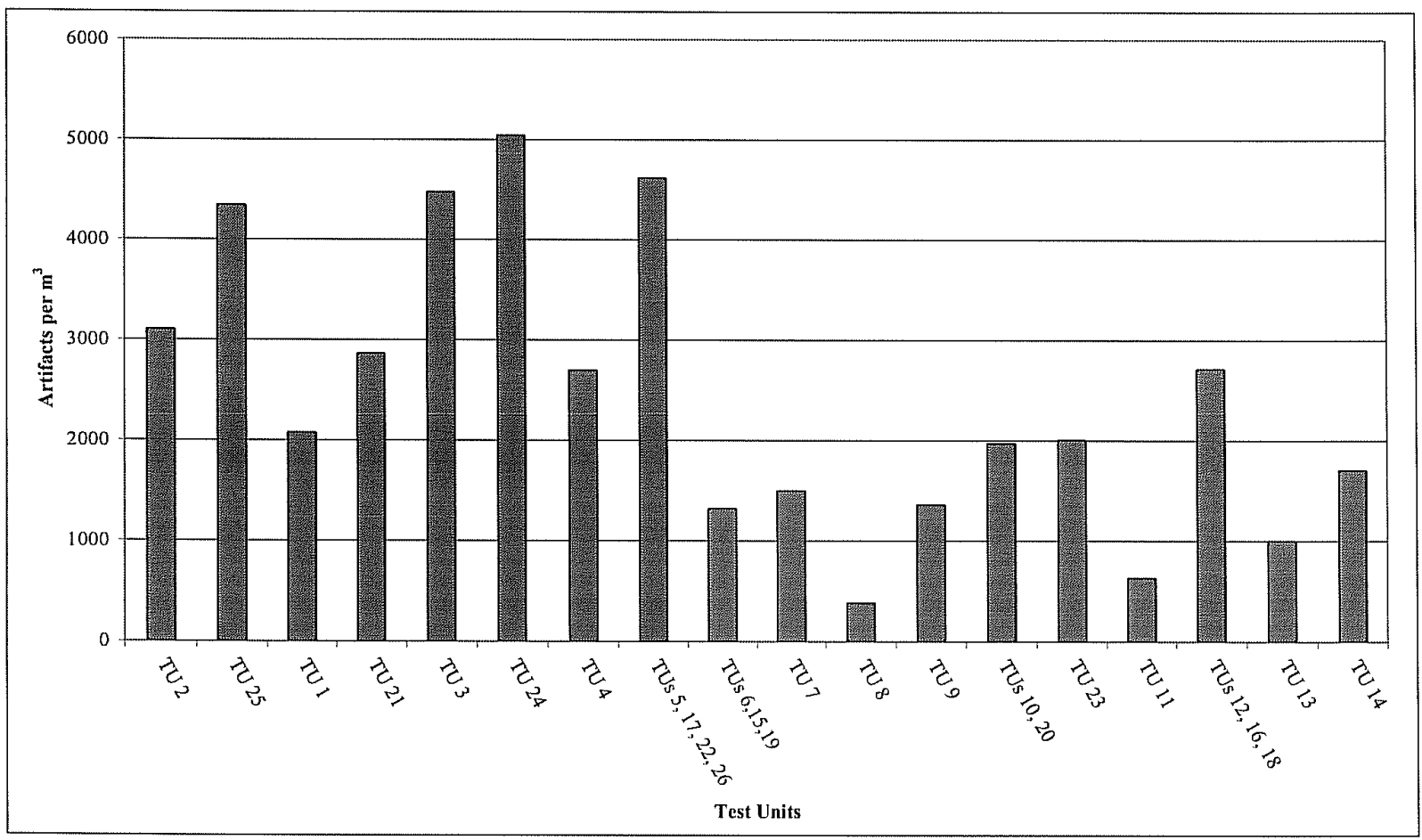

Figure 7-2. Artifact density (artifacts per $\mathrm{m}^{3}$ ) for units along the Hike-and-Bike Trail (south to north).

except the pit in Drainage System A. This pit did have some refuse in it, but it did not appear to have been originally dug as a trash pit, as the lowest levels of fill are nearly sterile (see Table 5-1).

\section{Are patterns of artifact dispersal apparent? If so, what can be inferred from such patterns?}

As mentioned above, there is a high density of artifacts in the gateway area and in the test units in the southern part of the Hike-and-Bike Trail. Test units with low artifact density include TUs $6,15,19,7,8,9,11,13,14$. As can be seen in Table 7-2, the datable artifacts from these units are divided almost evenly between the eighteenth, nineteenth, and twentieth centuries.

Units in the northern part of the Hike-and-Bike Trail with relatively high artifact density include TUs $10,20,12,16$, and 18 (see Figure 7-2). The datable artifacts from these units are shown in Table 7-3. The increased density can be attributed to a slightly higher count of Colonial artifacts, but the nineteenth-century artifacts make up almost $25 \%$ of the datable artifacts. Twentieth-century artifacts were only found in TUs 10, 20, and 23 .
How is the midden related to the nineteenthcentury houses known to have been placed along the wall?

It appears that nineteenth-century artifacts are much more common along the northern part of the Hike-and-Bike Trail. These may be associated with the jacal structures seen in Figure 2-2. Looking at the units with higher nineteenthcentury artifact counts (Tables 7-1 through 7-3), it is possible that the gate itself may have been one such breach. Another may have been located just north of the "gate room" (represented by TUs 26, 5, 17, 22, 19, 6, 15). This area would be associated with the house owned by Ramon Casillas ca. 1827 (Figure 2-2), and may also be associated with the stone house, probably built by Father Bouchu after 1868 (see Chapter 2).

Another area of relatively high nineteenth-century artifact density is seen in TUs 10,20, and 23. These may have been associated with the house owned by Ventura Hinojosa ca. 1827 (see Figure 2-2). TUs 12, 16, and 18 also have a relatively high count of nineteenth century artifacts, and may be associated with the house owned by Jana Gonzava ca. 1827 . 
Table 7-1. Total Datable Artifacts from Midden Along Hike-and-Bike Trail and Midden in Gateway Area

\begin{tabular}{|l|r|r|r|r|r|r|r|r|r|r|r|r|}
\hline & \multicolumn{10}{|c|}{ Midden in Hike-and-Bike Trail } & \multicolumn{1}{c|}{$\begin{array}{c}\text { Midden in } \\
\text { Gateway Area }\end{array}$} \\
\cline { 2 - 13 } \multicolumn{1}{c|}{ Approximate Dates } & TU 2 & TU 25 & TU 1 & TU 21 & TU 3 & TU 24 & TU 4 & $\begin{array}{c}\text { TU 26, 5, } \\
17,22\end{array}$ & Total & $\%$ & Ct. & $\%$ \\
\hline Colonial & 81 & 582 & 35 & 208 & 76 & 363 & 51 & 903 & 2299 & $88.0 \%$ & 556 & $76.1 \%$ \\
\hline 18th/19th Century & 11 & 7 & 10 & 7 & 2 & 6 & 16 & 19 & 78 & $3.0 \%$ & 72 & $9.8 \%$ \\
\hline 19th Century & 1 & 38 & 11 & 5 & 1 & 9 & 14 & 55 & 134 & $5.1 \%$ & 59 & $8.1 \%$ \\
\hline Late 19th/Early 20th Century & & & & & & 1 & & 50 & 51 & $2.0 \%$ & 14 & $1.9 \%$ \\
\hline 20th Century & & & 3 & & & 2 & 3 & 42 & 50 & $1.9 \%$ & 30 & $4.1 \%$ \\
\hline & & & & & & & & Total & 2612 & $100.0 \%$ & 731 & $100.0 \%$ \\
\hline
\end{tabular}

Table 7-2. Total Datable Artifacts from Units with Low Artifact Density on Hike-and-Bike Trail

\begin{tabular}{|l|r|r|r|r|r|r|r|r|r|}
\hline \multicolumn{1}{|c|}{ Approximate Dates } & TUs 6, 15, 19 & TU 7 & TU 8 & TU 9 & TU 11 & TU 13 & TU 14 & Totals & \% \\
\hline Colonial & 79 & 19 & 4 & 5 & 36 & 31 & 21 & 195 & $39.2 \%$ \\
\hline 18th/19th Century & 13 & 1 & & 5 & 3 & 2 & 4 & 28 & $5.6 \%$ \\
\hline 19th Century & 79 & 15 & 5 & 6 & 1 & 7 & 26 & 139 & $28.0 \%$ \\
\hline Late 19th/Early 20th Century & 22 & 2 & 1 & 5 & & 1 & 3 & 34 & $6.8 \%$ \\
\hline 20th Century & 54 & 2 & 3 & 25 & & 2 & 15 & 101 & $20.3 \%$ \\
\hline
\end{tabular}

Table 7-3. Total Datable Artifacts from Units with High Artifact Density on the Northern Hike-and-Bike Trail

\begin{tabular}{|l|r|r|r|r|r|}
\hline \multicolumn{1}{|c|}{ Approximate Dates } & TU 10, 20 & TU 23 & $\begin{array}{c}\text { TU 12, } \\
\mathbf{1 6 , 1 8}\end{array}$ & Total & \multicolumn{1}{c|}{$\%$} \\
\hline Colonial & 182 & 180 & 324 & 686 & $66.1 \%$ \\
\hline 18th/19th Century & 8 & 5 & 29 & 42 & $4.0 \%$ \\
\hline 19th Century & 54 & 165 & 36 & 255 & $24.6 \%$ \\
\hline Late 19th/Early 20th Century & 3 & 3 & 6 & 12 & $1.2 \%$ \\
\hline 20th Century & 6 & 36 & 1 & 43 & $4.1 \%$ \\
\hline \multicolumn{1}{|r|}{} & & Total & 1038 & $100.0 \%$ \\
\hline
\end{tabular}


It is important to realize, however, that these patterns involve a relatively small number of artifacts. Only $6.3 \%$ (584 of 9,289 ) of the total datable artifacts in the gateway and along the Hike-and-Bike Trail could be assigned reliably to the nineteenth century. The relatively small numbers strongly suggest that the inhabitant of the jacales built along the northern end of the west wall usually disposed of their trash somewhere else. The nineteenth-century artifacts recovered appear to be the result of occasional, casual trash disposal, not associated with a designated trash disposal area.

\section{To what extent are post-Colonial artifacts mixed} with Colonial artifacts? Have construction activities, especially the twentieth-century reconstruction of the walls, impacted the midden?

The artifacts in the Northwest Gateway units are, for the most part, fairly mixed. The number of post-Colonial artifacts is not high and these artifacts tended to be in the upper two levels, but most of the Colonial artifacts were also in the first two levels as well. This is not surprising, since most units in the gateway area were not dug deeper than Level 2.

Away from the gate itself, in the units of the gate midden along the southern part of the Hike-and-Bike Trail, there was relatively little disturbance noted except in TU 1 and TU 17. If one or two early-nineteenth-century whiteware sherds are ignored, most units in the midden have unmixed Colonial deposits beginning in either Level 3 or Level 4. An exception is TU 3, which, with the exception of a single piece of white earthenware in Level 1, appears to be complete unmixed Colonial midden (Table 5-8).

As mentioned above, the low-density units appear very mixed. Most have unmixed Colonial deposits only in the lowest levels, if at all. TU 14, in particular, is very mixed, all the way to Level 5 (Table 5-21).

The units with higher artifact densities in the northern part of the Hike-and-Bike Trail appear to be a mixed Colonial and nineteenth-century deposit, with fewer twentieth-century items, most of which are confined to the first level. TU 23 is an exception. It had mixed eighteenth-, nineteenth-, and twentieth-century artifacts all the way to Level 6 (Table 5-17).
Thus, the degree to which the artifacts tell of mixing of sediments varies along the Hike-and-Bike Trail. In some areas, especially TUs 1,17 , and 23 , a great deal of mixing has occurred. In the case of TUs 1 and 17, it is known that a pipe was laid through this area, probably causing the disturbance. It is not know why TU 23 is so mixed. In other units, mixing of datable artifacts is limited to the upper one or two levels.

\section{Was the brick feature observed in Drainage} System $A$ actually a kiln, and if so, what type of ceramic was fired there? Were a significant proportion of the ceramics at Espada made locally?

It is clear from the discussion at the opening of this chapter that the brick feature was a pottery kiln. The large number of ceramic sherds recovered from the kiln represent unglazed wares of a type not seen before at Mission Espada or at any of the other San Antonio missions. The pottery was wheelturned and most of the sherds represent shallow bowls with flattened bottoms. The kiln most likely dates to post-Colonial use of the mission since there are no records of potters' wheels at Mission Espada. The 960 sherds of kiln-made ceramics recovered from the kiln excavation represent $18.9 \%$ of all ceramic sherds recovered during this project. 


\section{Chapter 8: Summary and Conclusions}

Forty-nine test units and nine backhoe trenches were excavated during this project. In addition, archeologists monitored remaining portions of construction work in Drainage System A and the Espada Acequia.

The excavations performed during this project have allowed a glimpse into the lives of the many people who lived at the mission, from 1731 until well into the twentieth century. However, had the entire project been monitored by archeologists, as originally planned, the information gained would have been much more significant.

It is unfortunate that the kiln was disturbed so badly by the unmonitored construction work. It appears to be an example of early-nineteenth-century ceramic technology, and a great deal more could have been learned from it had it been excavated before the trenching activities destroyed a portion of the feature.

Disturbance to the area around the Northwest Gateway is also unfortunate, but certainly not the first such damage. Evidence seen during the excavation shows that the area has been disturbed many times, probably beginning in Colonial times and continuing through to the present. Damage to what remains of the foundations is due, among other things, to the multiple attempts to insert posts in this area and possibly to road grading as well. Laying of utilities through the area has also had an impact. But even though the area has been badly damaged by various activities over time, a very large number of Colonial artifacts are still present, and evidence of the unreconstructed southern gate room is still present.
The area along the Hike-and-Bike Trail presents a picture of varied disturbance. Some areas appear essentially intact. In particular, TUs $2,3,10,11,12,16,18,20,21,22,25$, and 26 had no twentieth-century artifacts below Level 1 . In the cases ofTUs $2,3,10,12,16,18,20,21$, and 26, however, this may be because the upper level had previously been removed by the unmonitored blading of the Hike-and-Bike Trail. In order to get a better idea of the extent of damage to historic deposits that occurred when the trail was bladed, the total number of artifacts dating from the eighteenth century to the early part of the twentieth century was compared to the number of such artifacts recovered from Level 1 of the non-bladed units. The percent of total historic artifacts found in Level 1 of theses units varied from $2 \%$ to $80 \%$, and averaged $28.1 \%$ (Table $8-1$ ). The implications are clear. The historic deposits along the Hike-and-Bike Trail are not deeply buried. Although in some areas there may have been little or no damage done to these deposits by the blading of the trail, in other areas significant damage was done, and on average more than a quarter of the historic artifacts may have been removed by this blading. Since, as can be seen in the tables in Chapter 5, at least some areas of the trail have essentially intact Colonial deposits, and these deposits tend to be near the ground surface; the damage done to the archeological record by this blading activity was significant.

The history of this portion of the Mission Trails Project provides an excellent example of why communication among all components of a large construction project that may impact historic properties is so important. While no one intended to cause the damage done to the historic

Table 8-1. Total Artifacts Dating from the Eighteenth through Early-Twentieth Centuries Compared to Such Artifacts Recovered from Level 1 in the Non-bladed Units along the Hike-and-Bike Trail

\begin{tabular}{|l|c|c|c|c|c|c|c|}
\hline & \multicolumn{7}{|c|}{ Non-Bladed Units } \\
\cline { 2 - 8 } & TU 25 & TU 7 & TU 5 & TU 9 & TU 23 & TU 11 & TU 13 \\
\hline $\begin{array}{l}\text { Total Artifacts Dating from 18th } \\
\text { Century to Early 20th Century }\end{array}$ & 627 & 37 & 68 & 21 & 353 & 40 & 41 \\
\hline Total in Level 1 & 88 & 18 & 2 & 2 & 38 & 12 & 33 \\
\hline$\%$ of Total in Level 1 & $14.0 \%$ & $48.6 \%$ & $2.9 \%$ & $9.5 \%$ & $10.8 \%$ & $30.0 \%$ & $80.5 \%$ \\
\hline
\end{tabular}


properties, failure to communicate among government agencies, contractors, subcontractors, and CAR resulted in significant damage to an important part of the history of San Antonio and Texas.

There was a great deal added to the growing body of information about the missions in San Antonio as a result of this project. However, a great deal more could have been learned, had CAR monitors been present from the beginning of construction in the area around Mission Espada. It is to be hoped that the lessons learned by all involved in this project will prevent similar occurrences in the future. 


\section{References Cited}

Adams, J. P.

1971 Bottle Collecting in America. New Hampshire Publishing Company, Somersworth.

Adams, W. H.

2002 Machine Cut and Wire Nails: American Production and Use for Dating $19^{\text {th }}$-Century and Early-20 $20^{\text {th }}$-Century Sites. Historical Archaeology 36(4):66-88.

Albert, L. S., and K. Kent

1949 The Complete Button Book. John Edwards, Stratford, Connecticut.

Almaráz, F. D.

1982 Land Tenure Study of the San Antonio Missions. Report prepared for the San Antonio Missions National Historical Park, National Park Service, San Antonio.

Andrefsky, W.

1998 Lithics, Macroscopic Approaches to Analysis. Cambridge University Press, New York.

Ayto, E. G.

1987 Clay Tobacco Pipes. Shire Publications Ltd. Aylesbury, Bucks, England. Second Edition, Shire Album 37.

Balkwill, D. M., and S. L. Cumbaa

1992 A Guide to the Identification of Postcranial Bones of Bos taurus and Bison bison. Canadian Museum of Nature, Ottawa.

Barnes, M. R.

1980 Mexican Lead-Glazed Earthenwares. In Spanish Colonial Frontier Research, compiled and edited by H. F. Dobyns. Spanish Borderlands Research No. 1, pp. 91-110. Center for Anthropological Studies, Albuquerque.

Boessneck, J.

1970 Osteological Differences Between Sheep (Ovis aries Linné) and Goats (Capra hircus Linné). In Science in Archaeology, edited by D. Brothwell and E. Higgs, pp. 331-358. Praeger, New York.

Bomar, G. W.

1999 Texas Weather: University of Texas Press, Austin.

Brain, J. P.

1979 Tunica Treasure. Peabody Museum of Archaeology and Ethnology, Harvard University, Cambridge, and the Peabody Museum of Salem, Massachusetts.

Bustanoby, J. H,

1947 Principles of Color and Color Mixing. McGraw-Hill Book Company, Inc., New York.

Buxton, F. W.

1957 Coffee. In The Encyclopedia Americana Vol.VII:209-211. Americana Corporation, New York. 
Clark, J. W., Jr.

1976 The Sugar Industry at Mission San José y San Miguel de Aguayo. Bulletin of the Texas Archaeological Society 47:245-260.

Cohen, A., and D. Serjeantson

1996 A Manual for the Identification of Bird Bones from Archaeological Sites. Revised edition. Archetype Publications, London.

Corbin, J. E., T. C Alex, and A. Kalina

1980 Mission Dolores de los Ais. Stephen F. Austin State University, Papers in Anthropology 2, Nacogdoches.

Corner, W.

1890 San Antonio de Bexar: A Guide and History. Bainbridge and Corner, San Antonio, Texas.

Cox, I. W.

1995 The Murderer in the Mission. Manuscript on file, Center for Archaeological Research, The University of Texas at San Antonio.

Crosby, H. A.

1977 Architecture of Texana, 1831-1883, Jackson County, Texas. Texas Archeological Survey, Research Report 57, Palmetto Bend Reservoir Series 2.

Cruz, G. R.

1983 San Antonio Missions National Historical Park, A Commitment to Research. San Antonio Missions National Historical Park, San Antonio.

Deagan, K.

1987 Artifacts of the Spanish Colonies of Florida and the Caribbean 1500-1800. Volume 1: Ceramics, Glassware, and Beads. Smithsonian Institution Press, Washington, D.C.

de Humboldt, A.

1941 Ensayo Politico Sobre al Reino de la Nueva España, edited and annotated by Vito Alesso Robles. Four volumes. Editorial Pedra Robredo, Mexico.

Drought, R. T. (surveyor)

1956 Plat of the Mission Espada Property, San Antonio, Bexar County, Texas. Job 29-S-133. Revised 8-6-56.

Durrenberger, E. P.

1965 Anderson's Mill (41TV130): A Historical Site in Travis County Texas. Bulletin of the Texas Archeological Society $36: 1-70$.

Escobedo, S.

1984 Untitled report on 1984 excavations at Mission Espada. Manuscript on file at the Center for Archaeological Research, The University of Texas at San Antonio.

Fisher, L. F., 1996 Saving San Antonio: The Preservation of a Heritage. Texas Tech University Press, Lubbock. 
Foster, G. M.

1955 Contemporary Pottery Techniques in Southern and Central Mexico. Middle American Research Institute, Tulane University, New Orleans.

Foster, W. C.

1995 Spanish Expeditions into Texas, 1689-1768. University of Texas Press, Austin.

Fox, A. A.

1981 Test Excavations at Mission San Francisco de la Espada. Archaeological Survey Report, No. 108. Center for Archaeological Research, The University of Texas at San Antonio.

1992 Archaeological Investigations in Alamo Plaza, San Antonio, Bexar County, Texas, 1988 and 1989. Archaeological Research Report, No. 205. Center for Archaeological Research, The University of Texas at San Antonio.

1999 Monitoring of Core Drilling and Testing at Missions San Juan Capistrano and San Francisco de la Espada, San Antonio, Bexar County, Texas. Report submitted to the Texas Antiquities Committee.

Fox, A. A., F. A. Bass, and T. R. Hester

1976 The Archaeology and History of Alamo Plaza. Archaeological Survey Report, No. 16. Center for Archaeological Research, The University of Texas at San Antonio.

Fox, A. A., and T. R. Hester

1976 Archaeological Test Excavations at Mission San Francisco de la Espada. Archaeological Survey Report 22. Center for Archaeological Research, The University of Texas at San Antonio.

Fox, D. E.

1979 The Lithic Artifacts of Indians at the Spanish Colonial Missions, San Antonio Texas. Special Report, No. 8. Center for Archaeological Research, The University of Texas at San Antonio.

Franklin, L. C.

1976 From Hearth to Cookstove. House of Collectibles, Florence, Alabama.

Gallo, J,

1985 Nineteenth and Twentieth Century Yellow Ware. Heritage Press, Richfield Springs, New York.

Gilbert, B. M.

1990 Mammalian Osteology. Missouri Archaeological Society, Columbia.

Gilmore, K.

1974 Mission Rosario, Archeological Investigations 1973. Archeological Report 14, Part 1. Texas Parks \& Wildlife Department, Historic Sites and Restoration Branch.

1975 Mission Rosario, Archeological Investigations 1974. Restoration Branch. Archeological Report 14, Part 2. Texas Parks and Wildlife Department, Historic Sites and Restoration Branch.

Godden, G. A.

1975 British Pottery, An Illustrated Guide. Clarkson N. Potter, Inc., New York.

Goggin, J. M.

1968 Spanish Majolica in the New World. Yale University Publications in Anthropology, Number 72. New Haven. 
Graham, J.

1978 Folk Housing in South and West Texas: Some Comparisons. In Proceedings - An Exploration of a Common Legacy: A Conference on Border Architecture, Marlene Elizabeth Heck, Project Director, Texas Historical Commission, Austin.

Grayson, D. K.

1984 Quantitative Zooarchaeology. Academic Press, New York.

Greer, G. H.

1981 American Stonewares. Schiffer Publishing Limited, Atglen, Pennsylvania.

1999 American Stonewares: The Art and Craft of Utilitarian Potters. Revised $3^{\text {rd }}$ Edition. Schiffer Publishing, Atglen, Pennsylvania.

Gross, K. J.

1997 Archaeological Testing of the New Plaza at Mission San Francisco de la Espada (41BX4), San Antonio, Texas. Archaeological Survey Report, No. 262. Center for Archaeological Research, The University of Texas at San Antonio.

Habig, M. A.

1968 The Alamo Chain of Missions. A History of San Antonio's Five Old Missions. Franciscan Herald Press, Chicago, Illinois.

Hafernick, D. B., I. W. Cox, and A. A. Fox.

1989 Archaeological Investigations of the San Juan Dam, 41 BX 226, Bexar County, Texas. Archaeological Survey Report, No. 179. Center for Archaeological Research, The University of Texas at San Antonio.

Hard. R. J., A. A. Fox, I. W. Cox, K. J. Gross, B. A. Meissner, G. J. Mendez, C. L. Tennis, and J. E. Zapata 1995 Excavations at Mission San José y San Miguel de Aguayo, San Antonio, Texas. Archaeological Survey Report 218. Center for Archaeological Research, The University of Texas at San Antonio.

Harris, R. K., and I. M. Harris

1967 Trade Beads, Projectile Points, and Knives, in A Pilot Study of Wichita Indian Archaeology and Ethnohistory, assembled by R. E. Bell, E. B. Jelks, and W. W. Newcomb, pp. 129-162. Report to the National Science Foundation, Southern Methodist University.

Harris, R. K., I. M. Harris, J. C. Blaine, and J. Blaine

1965 A Preliminary Archeological and Documentary Study of the Womack Site, Lamar County, Texas. Bulletin of the Texas Archeological Society 36:287-363.

Harris, R. K., I. M. Harris, and T. R. Hester

1999 A Study of Glass Beads, Coral Beads, and Bead Spacers from the San Juan Bautista and San Bernardo Missions, Guerrero, Coahuila, Mexico. Bulletin of the Texas Archeological Society 70:385-394.

Hawks, C.

2002.38 Smith and Wesson. Available online at $<\mathrm{http}: / /$ www.chuckhawks.com/38sw.htm>. Accessed December 11, 2002.

Herskovitz, R. M.

1978 Fort Bowie, Material Culture. The University of Arizona Press, Tucson. 
Hildebrand, $\mathrm{M}$.

1955 Skeletal Differences Between Deer, Sheep, and Goats. California Fish and Game 41:327-346.

Hillson, S.

1986 Teeth. Cambridge University Press, Cambridge.

Hughes, E., and M. Lester

1991 The Big Book of Buttons. New Leaf, Sedgewick, Maine.

Hughes, G. B.

1967 Victorian Pottery and Porcelain. Spring Books, London.

Israel, F. L. (editor)

19931897 Sears, Roebuck and Co. Catalogue. Chelsea House, New York.

Ivey, J. E., and A. A. Fox

1981 Archaeological Survey and Testing at Rancho de las Cabras, Wilson County, Texas. Archaeological Survey Report, No. 104. Center for Archaeological Research, The University of Texas at San Antonio.

1999 Archaeological Investigations at Mission Concepción and Mission Parkway. Archaeological Survey Report, No. 114. Center for Archaeological Research, The University Of Texas at San Antonio.

Ivey, J. E., M. B. Thurber, and S. Escobedo

1990 Of Various Magnificence: The Architectural History of the San Antonio Missions in the Colonial Period and the Nineteenth Century. Volume one. National Park Service, Southwest Regional Office, Southwest Cultural Resources Center, Professional Papers No. 11, Santa Fe. Draft on file at the Center for Archaeological Research at The University of Texas at San Antonio.

Kelly, H. E., A. A. Kowalsky, and D. E. Kowalsky

2001 Spongeware 1835-1935, Makers, Marks, and Patterns. Schiffer Publishing, Ltd., Altgen, Pennsylvania.

Kendrick, G.

1967 Bottle Fragments Betray Age of Historical Sites. El Palacio 74(2):19-24.

Killen, K. L., and D. Scurlock

1977 A Report on Preliminary Test Excavations at Mission Espada Kilns, San Antonio, Texas. Preliminary Draft. Manuscript on file, Center for Archaeological Research, The University of Texas at San Antonio.

Kneupper, C.

1994 Buttons in Texas Archeological Society 1994 Field School Manual. Lake Jackson, Texas, June 11-18, 1994.

Lister, F. C., and R. H. Lister

1974 Majolica in Colonial Spanish America. Historical Archaeology 8:17-52.

Lorrain, D.

1968 An Archaeologist's Guide to Nineteenth Century American Glass. Historical Archaeology 22:35-44.

Lyman, R. L.

1994 Vertebrate Taphonomy. Cambridge University Press, Cambridge. 
Lyman, R. L., and M. J. O'Brien

1987 Plow-Zone Zooarchaeology: Fragmentation and Identifiability. Journal of Archaeological Science 16:293-317.

Majewski, T., and M. O'Brien

1987 The Use and Misuse of Nineteenth-Century English and American Ceramics in Archaeological Analysis, in Advances in Archaeological Method and Theory 11, edited by M. B. Schiffer. Academic Press, Inc., New York.

Maxwell, D. B. S.

1993 Beer Cans: A Guide for the Archaeologist. Historical Archaeology 27(1):95-113.

McKee, L. W., and P. E. Langenwalter

1985 Vertebrate Faunal Remains from the Kiln. In Excavations at Mission San Antonio 1976-1978, edited by R. L. Hoover and J. G. Costello, pp. 146-151. Monograph XXVI, Institute of Archaeology, University of California, Los Angeles.

McKenzie, C. M. M.

1989 Independent Study Report on Guanajuato Majolica in the San Antonio Missions Area. Unpublished manuscript on file at the Center for Archaeological Research at The University of Texas at San Antonio.

Meissner, B. A.

1997 Making the Man: Clothing Remains from the Alamodome Project. In Archaeology at the Alamodome: Investigations of a San Antonio Neighborhood in Transition, Vol. III, Artifact and Special Studies, edited by A. A. Fox, M. Renner, and R. J. Hard, pp. 119-164. Archaeological Survey Report, No. 238. Center for Archaeological Research, The University of Texas at San Antonio.

1998a Archeological Monitoring of an Electrical Conduit Trench at Mission San Francisco de la Espada (41BX4), San Antonio, Bexar County, Texas. Archaeological Survey Report, No. 288. Center for Archaeological Research, The University of Texas at San Antonio.

1998 b Vertebrate Faunal Remains. In Mission San José Indian Quarters Foundation Project, Bexar County, Texas: With Appendixes on the Monitoring of the San José Bus Drive and Granary Parking Lot, and on the Monitoring and Shovel Testing of the San José Service Drive, by S. A. Tomka and A. A. Fox. Archaeological Survey Report, No. 278. Center for Archaeological Research, The University of Texas at San Antonio.

1999a Analysis of Vertebrate Faunal Remains from a Spanish Colonial Deposit at Mission San Antonio de Valero (the Alamo). Bulletin of the Texas Archeological Society 70:281-313.

1999b Vertebrate Faunal Remains. In Archaeological Investigation of Rainwater Catchment Basins Along the South Wall of Mission San José, San Antonio, Texas, by S. A. Tomka and A. A. Fox, pp. 39-46. Archaeological Survey Report, No. 287. Center for Archaeological Research, The University of Texas at San Antonio.

1999c Vertebrate Faunal Remains. In Mission San José Repointing and Underpinning Project, San Antonio, Texas, by S. A. Tomka, A. A. Fox, and B. A. Meissner, pp. 35-41. Archaeological Research Report, No. 294, Center for Archaeological Research, The University of Texas at San Antonio.

2000a Vertebrate Faunal Remains. In Archaeological Excavations of the Priest Quarters, Mission San Francisco de la Espada, 41BX4, San Antonio, Texas, by J. E. Zapata, M. J. Brown, and J. J. Durst, pp. 47-60. Archaeological Survey Report, No. 295. Center for Archaeological Research, The University of Texas at San Antonio.

2000b Mission Concepción. In Archaeological Investigations at Four San Antonio Missions: Mission Trails Underground Conversion Project, edited by C. L. Tennis, pp. 59-99. Archaeological Survey Report, No. 297. Center for Archaeological Research, The University of Texas at San Antonio.

2000c Vertebrate Faunal Remains (San Juan). In Archaeological Investigations at Four San Antonio Missions: Mission Trails Underground Conversion Project, edited by C. L. Tennis, pp. 32-42. Archaeological Survey Report, No. 297. Center for Archaeological Research, The University of Texas at San Antonio. 
2002 Other Historic Artifacts. In Archaeological Investigations at the Last Spanish Colonial Mission Established on the Texas Frontier: Nuestra Señora del Refugio (4IRFI), Refugio County, Texas. Volume I: Archaeological Investigation, by C. L. Tennis, pp. 221-230. Archeological Studies Program, Report No. 39, Environmental Affairs Division, Texas Department of Transportation, Austin; and Archaeological Survey Report, No. 315, Center for Archaeological Research, The University of Texas at San Antonio.

2003 Vertebrate Faunal Remains from Fort Saint Louis. Report in preparation.

Meskill, F. K.

1992 Archaeological Testing Within the Southeast Corner of the Plaza at Mission Espada, San Antonio, Bexar County, Texas. Archaeological Survey Report, No. 108. Center for Archaeological Research, The University of Texas at San Antonio.

Miller, G.

2000 A Revised Set of CC Index Values for Classification and Economic Scaling of English Ceramics from 1787 to 1880 in Approaches to Material Culture, Research for Historical Archaeologists, Second Edition, compiled by D. R. Brauner, pp. 86-110. The Society for Historical Archaeology, California, Pennsylvania.

Miller, G. L., and A. Pacey

1985 Impact of Mechanization in the Glass Container Industry: The Dominion Glass Company of Montreal, a Case Study. Historical Archaeology 19(1):38-50.

Miller, J. J., II, and L. M. Stone

1970 Eighteenth Century Ceramics from Fort Michilimackinac, A Study in Historical Archaeology. Smithsonian Studies in History and Technology 4, Smithsonian Institution Press, Washington, D.C.

Mirkin, A. (editor)

19701927 Edition of The Sears, Roebuck Catalogue. Crown Publishers, Inc., New York.

Mission Records [MR] 62-70

1824 Appraisal of the Houses at Mission San Francisco de la Espada by José Antonio Saucedo, Jefe Politico of Bexar, September 30,1824. Archives of the County Clerk, Bexar County Courthouse.

Mission Record [MR] 65

1830 Description of the Houses and Lands Pertaining to the Inhabitants of Mission San Francisco de la Espada, 1827. San Fernando de Bexar, November 24, 1830. Archives of the County Clerk, Bexar County Courthouse.

Mounger, M. A.

1959 Mission Espiritu Santo of Coastal Texas: An Example of Historic Site Archeology. Unpublished Masters Thesis, University of Texas, Austin.

Munsey, C.

1970 The Illustrated Guide to Collecting Bottles. Hawthorn Books, Inc., New York.

Newman, T. S.

1970 A Dating Key for Post-Eighteenth Century Bottles. Historical Archaeology IV:70-75.

Nickels, D. L.

20001999 Excavations at Mission Rosario. Archaeological Research Report, No. 298. Center for Archaeological Research, The University of Texas at San Antonio. 
Nicholson, R. A.

1996 Bone Degradation, Burial Medium and Species Representation: Debunking the Myths, an Experiment-Based Approach. Journal of Archaeological Science 23:513-533.

Noël Hume, I.

1969 Historical Archaeology. Alfred A. Knopf, New York.

1982 Martin's Hundred: The Discovery of a Lost Colonial Virginia Settlement. Dell Publishing, New York.

Norwine, J.

1995 The Regional Climate of South Texas: Patterns and Trends. In The Changing Climate of Texas: Predictability and Implications for the Future, edited by J. Norwine, J. R. Giardino, G. R. North and J. B. Valdez, pp. $138-154$. Cartographics, Texas A\&M University. College Station, Texas.

Olsen, S. J.

1960 Post-Cranial Skeletal Characters of Bison and Bos. Peabody Museum, Cambridge.

1964 Mammal Remains from Archaeological Sites Part I; Southeastern and Southwestern United States. Peabody Museum, Cambridge.

1968 Fish, Amphibian, and Reptile Remains from Archaeological Sites Part I: Southeastern and Southwestern United States. Peabody Museum, Cambridge.

Pool, J. C.

1987 Appendix V: Fanthorp Inn: A Study of Nineteenth and Twentieth Century Buttons, in Archeological Excavations at Fanthorp Inn State Historic Site (4IGM79), Grimes County, Texas, Spring and Fall 1982, by J. D. Ing and J. Hart, pp. 277-290. Texas Parks and Wildlife Department, Historic Sites and Restoration Branch, Austin.

Potter, D. R., S. L. Black, and K. Jolly

1995 Archeology Along the Wurzbach Parkway. Module I: Introduction, Conceptual Framework, and Contexts of Archeological Investigations in Bexar County, South-Central Texas. Studies in Archeology No. 17. Texas Archeological Research Laboratory, The University of Texas at Austin.

Ray, M.

1974 Collectible Ceramics. Crown Publishers, Inc., New York.

Reitz, E. J., and E. S. Wing

1999 Zooarchaeology. Cambridge University Press, Cambridge.

Rice, P. M.

1987 Pottery Analysis, A Sourcebook. The University of Chicago Press, Chicago.

Ricklis, R. A.

2000 Archeological Investigations at the Spanish Colonial Missions of Espiritu Santo (4IGDI) and Nuestra Señora del Rosario (41GD2), Goliad County, Texas. Coastal Archeological Studies, Inc., Corpus Christi, Texas.

Robacker, E. F., and A. F. Robacker

1978 Spatterware and Sponge, Hardy Perennials of Ceramics. A. S. Bames and Company, New Jersey.

Sáenz de Gumiel, J. J.

1772 Ynventario de la Espada. Zacatecas and Celaya microfilm, Reel 13, frames 1338-1374, December 15. Old Spanish Missions Historical Research Library, Our Lady of the Lake University, San Antonio, Texas. 
San Antonio Express

1939 "Society to Buy Mission Aqueduct." San Antonio Express, March 12, 1939.

San Antonio Light

1959 “Espada Dam Lake Due Next Summer." San Antonio Light, August 2, 1959.

1969 Article on Coca Cola bottling works to open in San Antonio. San Antonio Light, September 27, 1969.

Schmid, E.

1972 Atlas of Animal Bones for Prehistorians, Archaeologists, and Quaternary Geologists (Knochenatlas Für Prähistoriker; Archäologen und Quartärgeologen). Elsevier Publishing, Amsterdam.

Schuetz, M. K.

1969 The History and Archeology of Mission San Juan Capistrano, San Antonio, Texas, Volume II. State Building Commission Archeology Program, Report Number 11, Austin.

1970 Excavation of a Section of the Acequia Madre in Bexar County, Texas, and Archeological Investigations at Mission San José in April 1968. Texas Historical Survey Committee, Archeological Report 19, Austin.

1973 Archeological Investigations at Mission San Antonio de Valero, The Second Patio. Unpublished manuscript on file, Office of the State Archeologist, Texas Historical Commission, Austin.

1980 The Indians of the San Antonio Missions, 1718-1821. Unpublished Ph.D. dissertation, The University of Texas at Austin.

Seifert, D. J.

1977 Archaeological Majolicas of the Rural Teotihuacan Valley, Mexico. Unpublished Ph.D. dissertation, The University of Iowa.

Sobolik, K. D., and D. G. Steele

1996 A Turtle Atlas to Facilitate Archaeological Identifications. Mammoth Site of Hot Springs, SD, Inc., Rapid City, $\mathrm{SD}$.

South, S.

1999 Excavating the Pottery of John Bartlam: America's First Creamware Potter. In Old and New Worlds, edited by G. Egan and R. L. Michael, pp. 289-298. Oxbow Books, Oxford, England.

Stelle, L. J.

2001 An Archaeological Guide to Historic Artifacts of the Upper Sangamon Basin. Center For Social Research, Parkland College. Available online at <http:/virtual.parkland.cc.il.us/lstelle1/len/archguide/documents/arcguide.htm>. Accessed December 16, 2002.

Sudbury, B.

1979 Historic Clay Tobacco Pipemakers in the United States of America. Reprint from The Archaeology of Clay Tobacco Pipes, II. The United States of America. BAR International Series No. 60.

Thurber, M. B., S. Escobedo, T. Ireland, and J. E. Ivey

1993 Of Various Magnificence: The Architectural History of the San Antonio Missions in the Colonial Period and the Nineteenth Century, Volume Two. National Park Service Professional Papers No. 11, Santa Fe, Draft on file at the Center for Archaeological Research, The University of Texas at San Antonio. 
Taylor, F. B., R. B. Hailey, and D. L. Richmond

1991 Soil Survey of Bexar County, Texas. United States Department of Agriculture, Soil Conservation Service, Washington, D.C.

Tennis, C. L.

2001 Mission Espada. In Archaeological Investigations at Four San Antonio Missions: Mission Trails Underground Conversion Project, edited by C. L. Tennis, pp. 111-116. Archaeological Survey Report, No. 297. Center for Archaeological Research, The University of Texas at San Antonio.

2002 Archeological Investigations at the Last Spanish Colonial Mission Established on the Texas Frontier: Nuestra Señora del Refugio (4IRF1), Refugio County, Texas. Archeological Studies Program, Report No. 39, Environmental Affairs Division, Texas Department of Transportation, Austin; and Archaeological Survey Report, No. 315, Center for Archaeological Research, The University of Texas at San Antonio.

Tomka, S. A.

2002 Metal Arrow Points. In Archaeological Investigations at the Last Spanish Colonial Mission Established on the Texas Frontier: Nuestra Señora del Refugio (41RF1), Refugio County, Texas. Volume I: Archaeological Investigation, by C. L. Tennis, pp. 231-232. Archeological Studies Program, Report No. 39, Environmental Affairs Division, Texas Department of Transportation, Austin; and Archaeological Survey Report, No. 315, Center for Archaeological Research, The University of Texas at San Antonio.

Tomka, S. A, and A. A Fox

1998 Mission San José Indian Quarters Wall Base Project, Bexar County Texas. Archaeological Survey Report, No. 278. Center for Archaeological Research, The University of Texas at San Antonio.

1999 Archaeological Investigations of Rainwater Catchment Basins Along the South Wall of Mission San José, San Antonio, Texas. Archaeological Survey Report 287. Center for Archaeological Research, The University of Texas at San Antonio.

Tomka, S. A, A. A. Fox, and B. A Meissner.

1999 Mission San José Repointing and Underpinning Project, San Antonio Texas. Archaeological Survey Report, No. 294. Center for Archaeological Research, The University of Texas at San Antonio.

Toulouse, J. H.

1971 Bottle Makers and Their Marks. Thomas Nelson, New York.

Tunnell, C., and W. W. Newcomb, Jr.

1969 A Lipan Apache Mission, San Lorenzo de la Santa Cruz, 1762-1771. Bulletin of the Texas Memorial Museum 14, The University of Texas, Austin.

Vaughan, M.

1997 Kitchen Utensils and Tablewares, Chapter 7. In Archaeology at the Alamodome: Investigations of a San Antonio Neighborhood in Transition, Volume III: Artifact and Special Studies, edited by A. A. Fox, M. Renner, and R. J. Hard, pp. 209-228. Archaeological Survey Report, No. 238. Center for Archaeological Research, The University of Texas at San Antonio.

Vehik, S. C.

1977 Bone Fragments and Bone Grease Manufacturing: A Review of Their Archaeological Use and Potential. Plains Anthropologist 22:169-182. 
Von Endt, D. W., and D. J. Ortner

1984 Experimental Effects of Bone Size and Temperature on Bone Diagenesis. Journal of Archaeological Science $11: 247-253$.

Yakubik, J. K.

1990 Ceramic Use in Late Eighteenth Century and Early Nineteenth Century Southeastern Louisiana. Ph.D. dissertation, Tulane University.

Zapata, J. E., M. J. Brown, and J. J. Durst

2000 Archaeological Excavations of the Priest Quarters, Mission San Francisco de la Espada, 41BX4, San Antonio, Texas. Archaeological Survey Report, No. 295. Center for Archaeological Research, The University of Texas at San Antonio. 
